\author{
Universidade de São Paulo \\ Faculdade de Filosofia Letras e Ciências Humanas \\ Programa de Pós-Graduação em Sociologia
}

Pedro Giovanetti Cesar Pires

\title{
Representações da modernidade brasileira na canção: o caso de Clara Crocodilo
}

Tese apresentada ao Programa de Pós-Graduação em Sociologia da Faculdade de Filosofia Letras e Ciências Humanas da Universidade de São Paulo, para a obtenção de título de Doutor em Sociologia

Orientadora: Maria Helena Oliva Augusto

São Paulo

2019 
Autorizo a reprodução e divulgação total ou parcial deste trabalho, por qualquer meio convencional ou eletrônico, para fins de estudo e pesquisa, desde que citada a fonte.

Catalogação na Publicação

Serviço de Biblioteca e Documentação

Faculdade de Filosofia, Letras e Ciências Humanas da Universidade de São Paulo

Cesar Pires, Pedro

Representações da modernidade brasileira na canção

$\operatorname{Cr}$ popular: o caso de Clara Crocodilo / Pedro Cesar Pires ; orientador Maria Helena Augusto. - São Paulo, 2019.

$268 \mathrm{f}$.

Tese (Doutorado)- Faculdade de Filosofia, Letras e Ciências Humanas da Universidade de São Paulo. Departamento de Sociologia. Área de concentração: Sociologia.

1. Canção. 2. Sociologia da Cultura. 3. Representações. 4. Cultura e Política. 5. Modernidade. I. Augusto, Maria Helena, orient. II. Título. 
CESAR PIRES, Pedro. Representações da modernidade brasileira na canção: o caso de

Clara Crocodilo. Tese apresentada à Faculdade de Filosofia, Letras e Ciências Humanas da Universidade de São Paulo para a obtenção do título de Doutor em Sociologia.

Aprovado em:

Banca examinadora:

Prof.

Dr. Instituição:

Julgamento: Assinatura:

Prof.

Dr. Instituição:

Julgamento: Assinatura:

Prof.

Dr. Instituição:

Julgamento: Assinatura: 


\section{Agradecimentos}

Este trabalho deve sua existência, em primeiro lugar, a todas e todos que devotam suas vidas para o avanço das ciências humanas neste país: somos o grande estorvo daqueles que fazem da ignorância e da brutalidade um projeto político para o Brasil. Que o ataque dos boçais reafirme a certeza quanto a importância da nossa tarefa.

Agradeço minha orientadora Maria Helena Oliva Augusto pela parceria que começou já nos anos de graduação: seu apoio intelectual e pessoal é inestimável. Agradeço a todos os professores das Ciências Sociais da Universidade de São Paulo, cuja excelência no ensino e pesquisa foi conquistada tão somente pelo sacrifício e comprometimento de cada um deles.

Aos amigos e colegas, companheiros de jornada, vocês são muito mais importantes para mim do que minhas palavras e silêncios dão a entender. Queria ter todos vocês sempre por perto, minha dívida de gratidão para cada um é imensa.

Aos meus pais pelo apoio incondicional, minha irmã, tios, primos e avós.

Em especial, agradeço a Olha Zolotarenko, esse rio que passou em minha vida e mudou o traçado dela e desta tese.

Este trabalho foi realizado graças ao apoio do CNPq. Expresso minha gratidão para esta instituição e o desejo de que a pesquisa científica brasileira não se torne objeto exclusivo da história. 


\section{RESUMO}

\section{CESAR PIRES, Pedro. Representações da modernidade brasileira na canção: o caso de}

Clara Crocodilo. Tese (Doutorado). Faculdade de Filosofia, Letras e Ciências Humanas da Universidade de São Paulo 2019.

O presente trabalho procura desvendar como a noção de modernidade brasileira foi representada em momentos chave da canção nacional, tendo o álbum Clara Crocodilo (1980), de Arrigo Barnabé, como ponto de partida para a pesquisa de períodos anteriores. Procuramos clarificar quais são as linhas de força da canção que se fazem presentes neste álbum, assim como qual é a representação de modernidade nele articulada, para então reconstruir como tais linhas se desenvolveram em momentos precedentes, a saber: o samba dos anos 1920 e 1930, a bossa nova, a canção engajada dos anos 1960 e a tropicália. O que chamamos de linha de força são: a representação do popular, a aspiração pela modernização como superação do subdesenvolvimento e a posição da canção na esfera pública. Nosso objeto de pesquisa é, em primeiro lugar, as próprias canções, entendidas aqui como uma prática de representação. Mas também procuramos reconstruir a dinâmica social e política na qual essa prática estava inserida, sem a qual ela é incompreensível. O interesse pela canção como prática de representação advém da grande importância que essa forma artística teve na sociedade brasileira: seja porque até meados do século $\mathrm{XX}$ a maior parte da população esteve excluída da cultura letrada (analfabetismo), seja por conta do ataque da ditadura militar às organizações políticas de esquerda ter feito da canção, até o AI-V em 1968, um espaço privilegiado para o engajamento civil. Nossa hipótese é que o álbum de Arrigo Barnabé é revelador de uma crise não apenas da aspiração pela modernização da sociedade brasileira, mas também de um nicho da canção brasileira: de sua capacidade de articular um discurso global a respeito do Brasil, da sua posição ante a reorganização da indústria fonográfica, da sua posição ante o popular.

Palavras-chave: Canção, Sociologia da Cultura, Representações, Cultura e Política, Modernidade 


\begin{abstract}
ABSTARCT
CESAR PIRES, Pedro. Representations of the brazilian modernity in popular music: the case of Clara Crocodilo. Tese (Doutorado). Faculdade de Filosofia, Letras e Ciências Humanas da Universidade de São Paulo 2019.
\end{abstract}

This work aims to uncover how the notion of Brazilian modernity was represented in keymoments of the national popular song, having the Arrigo Barnabé's album Clara Crocodilo (1980) as the starting point for the research of past periods. We make an effort to clarify what are the main lines of the popular music development present in this album and the modernity's representation that emerges from it, so we can reconstruct how such lines and modernity representation had evolved in previous moments, namely: the samba of the $1920 \mathrm{~s}$ and 1930s, the bossa nova, the engaged song of the 1960s and the tropicália. What we call "main lines" are: the representation of the popular, the aspiration for modernity as the overcome of underdevelopment and the popular music's position in the public sphere. Our research object are the songs, understood as a work of representation. But we also aim to reconstruct the social and political dynamic where this work was entangled. The interest in popular music as a work of representation comes from the great importance of this art form in Brazilian society: that being because the majority of the population were until mid XX century excluded from the written culture, as well as a consequence of the military dictatorship's attack over the left-wing political organizations that made from the popular music one of the main spaces of civil engagement. Our hypothesis is that the album from Arrigo Barnabé is revealing a crisis, not only from the aspiration for a Brazilian modernity, but also from a niche of the Brazilian song: its ability to articulate a global discourse about Brazil, its position in relation to the reorganization of the music industry and its position in relation to the popular.

Keywords: Popular music, Sociology of Culture, Representation, Culture and Politics, Modernity 


\section{Sumário}

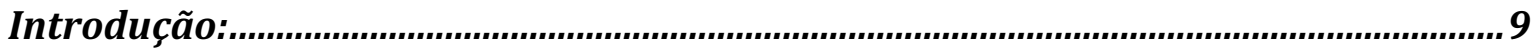

Capítulo I: Arrigo Barnabé e a Vanguarda Paulista................................................ 15

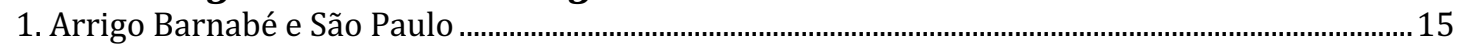

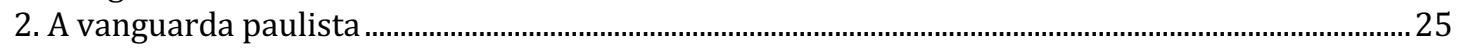

2.1 Tropicália e a ideia da linha evolutiva ……………………………………………………………...28

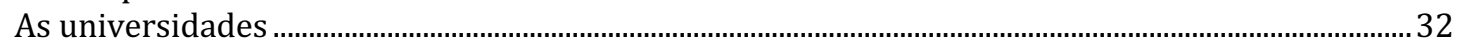

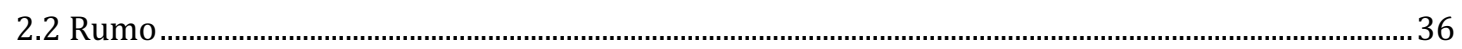

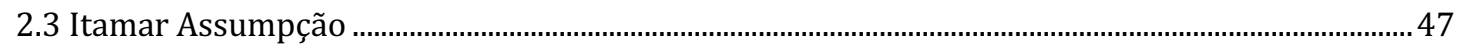

2.5 Língua de Trapo e Premeditando o Breque .........................................................................................51

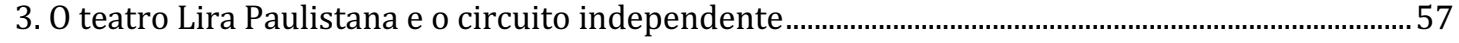

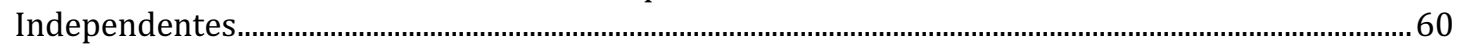

O fim do Lira Paulistana e a dispersão da Vanguarda Paulista ....................................................................64

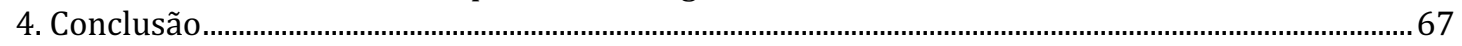

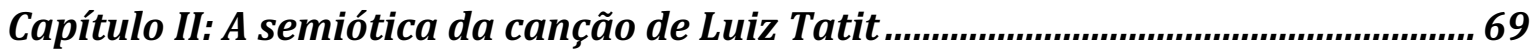

1. Reconhecendo a canção: entoação e junção de melodia e letra............................................................70

2. Modos de unir melodia e letra: tematização, passionalização, figurativização e musicalização 74

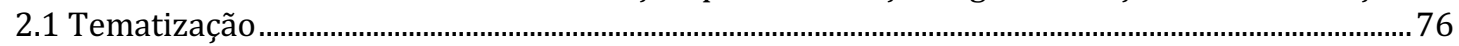

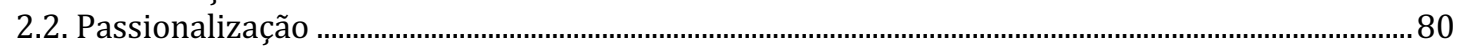

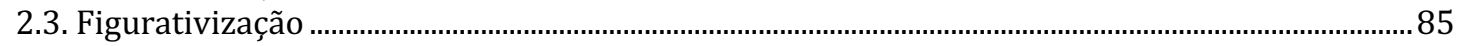

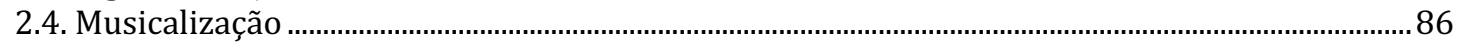

2.5. A articulação das quatro tendências ................................................................................................90

3. Ilusão enunciativa …………………..................................................................................................

4. Axiologia

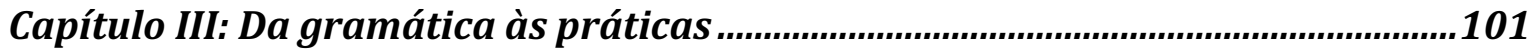

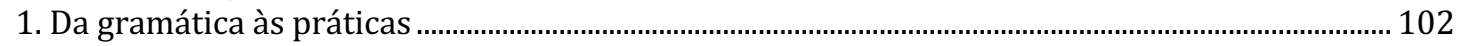

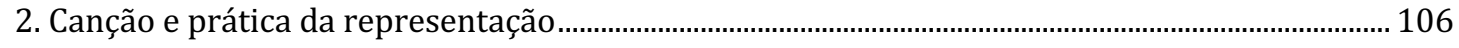

3. A representação do "eu" na canção popular.......................................................................................... 110

3.1. As potencialidades de Goffman para se pensar a canção ....................................................................113

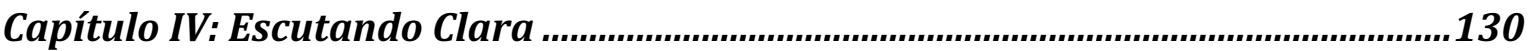

1. Acapulco Drive in .......................................................................................................................................... 133

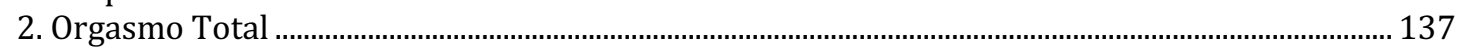

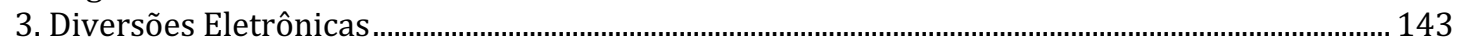

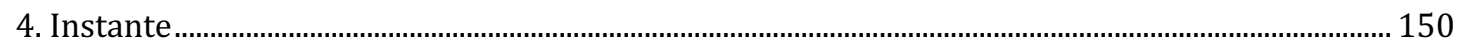

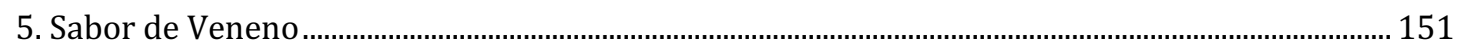

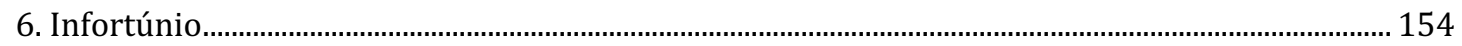

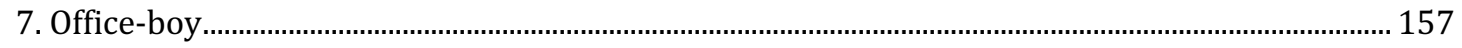

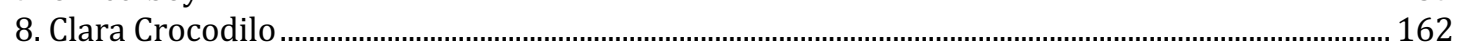

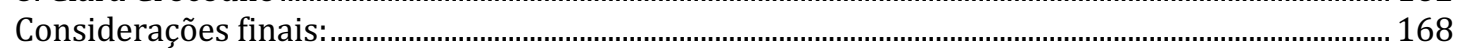

Capítulo V: Nacionalização e internacionalização do samba nas décadas de 1920

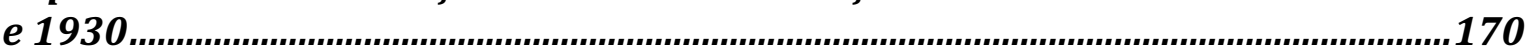

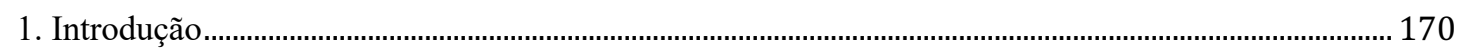

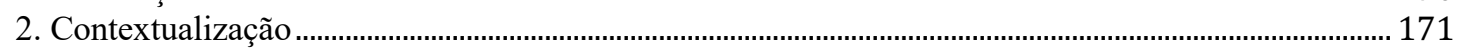

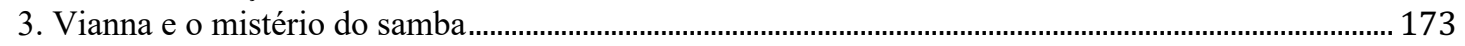

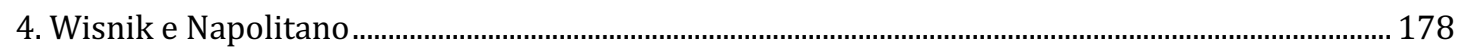

5. Noel Rosa e Wilson Batista.............................................................................................................. 181

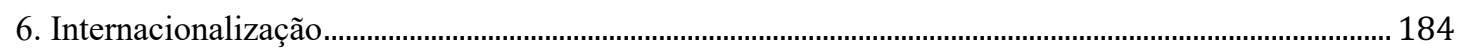

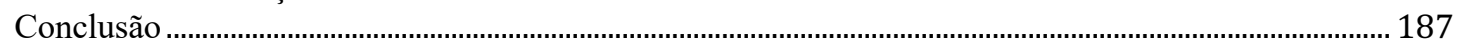

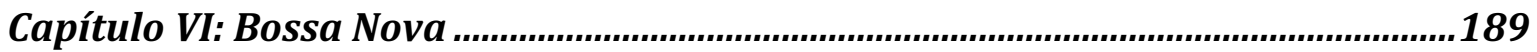

1. Nacionalização e internacionalização da bossa nova ......................................................................... 189

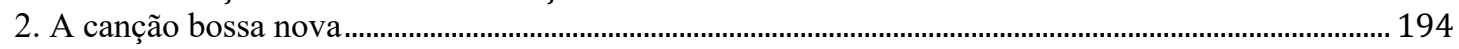

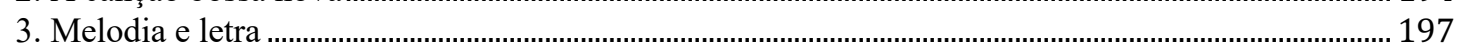




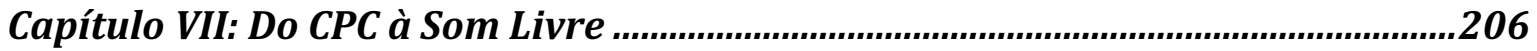

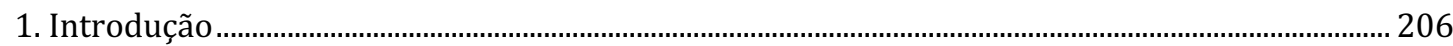

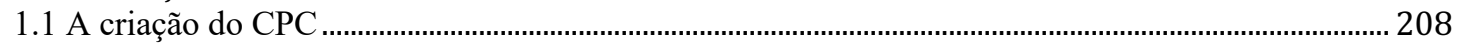

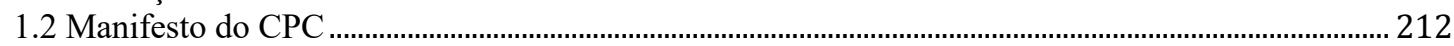

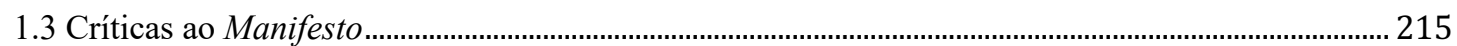

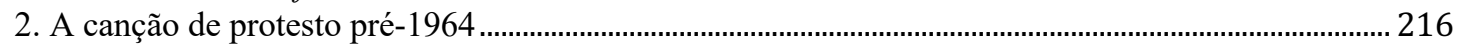

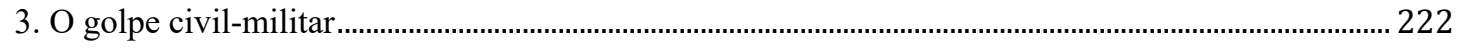

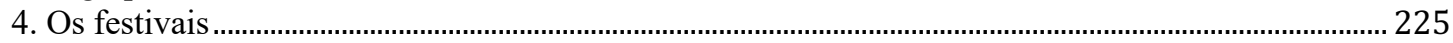

5. A estruturação da indústria cultural brasileira.............................................................................................. 226

6. Reestruturação da indústria fonográfica............................................................................................. 228

\section{Capítulo VIII: Moderno, arcaico e mítico: o Brasil moderno e eterno na tropicália}

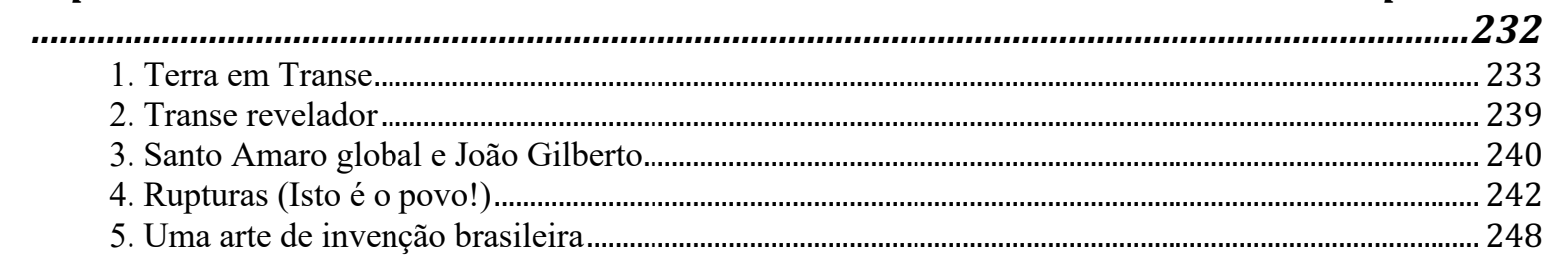

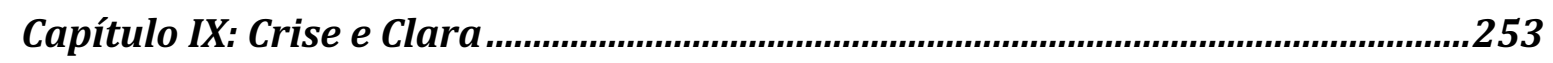

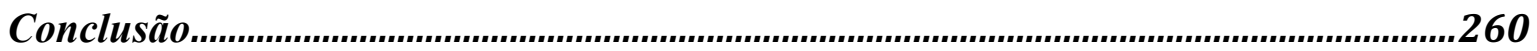

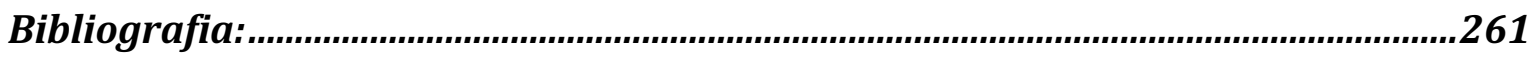




\section{Introdução:}

$\mathrm{Na}$ abertura dos Jogos Olímpicos de 2016, no Rio de Janeiro, assistiu-se a um interessante espetáculo de representações do Brasil. Logo no início da cerimônia, o hino nacional foi executado por um músico popular, Paulinho da Viola, acompanhado por uma formação orquestral. O hino, em sua versão original, tem a melodia carregada de frases musicais com ritmos marcados, que insuflam o páthos, o heroísmo e o sentimento de dever pátrio, reafirmado pela letra que fala de grandeza, luta e morte. Mas nas mãos do sambista, os tempos fortes escorregaram para o suingue em sutis quebras de ritmo, "fazendo a marcha

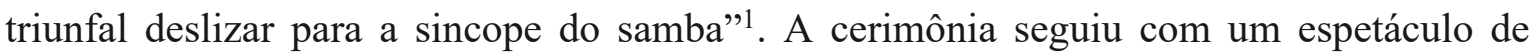
alegorias, as quais reconstruíam a história brasileira. Mas essa história, os grupos e os espaços sociais foram todos sendo acompanhados e aludidos por gêneros de canções populares: a bossa nova de Tom Jobim, os afro-sambas, o samba, o funk, o rap... A certa altura, o avião 14-Bis de Santos Dumont alçou voo ao som do Samba do Avião de Tom Jobim, numa clara metáfora de uma modernidade brasileira, modernidade sonhada e elaborada ao longo de todo o século XX no imaginário das artes, e principalmente na canção popular: "miragem de um país que um dia vislumbrou uma modernidade singular: livre, generosa e socializável". ${ }^{2}$

Nos momentos finais da cerimônia, Caetano Veloso, Gilberto Gil e Anitta cantaram o samba de Ary Barroso Isto aqui o que é?, imagem e performance que não poderia ser mais explícita no sentido de mostrar o próprio Brasil sendo referenciado por uma canção, um país que representa a si mesmo nas e pelas canções: Isto aqui ô $\hat{o}$ / É um pouquinho de Brasil Iaiá / Deste Brasil que canta e é feliz. A escolha dos cantores, dois representantes da MPB em seus dias de glória nos meios de comunicação e resistência à ditadura militar e uma cantora de grande sucesso popular hoje, provavelmente pretendia indicar a permanência e a continuidade daquele Brasil sonhado e do prestígio da canção popular. Mas há ainda uma outra permanência. Ao longo do século XX, as artes, e principalmente a canção popular elaboraram esteticamente os impasses políticos e sociais do Brasil, país que sonhava com uma modernidade livre desses impasses, "país do futuro" que se projetava no novo: música nova, cinema novo, bossa nova, nova arquitetura... País que nos anos 1960 acreditou estar próximo do objetivo, assim como nos anos de crescimento e otimismo econômico do

\footnotetext{
${ }^{1}$ Guilherme Wisnik. Cerimônia mostrou um Brasil que ainda pulsa e se atualiza diante de nós. Folha de São Paulo. São Paulo, 08 agosto 2016. Disponível em: http://www1.folha.uol.com.br/colunas/guilherme-wisnik/2016/08/1800104-cerimonia-mostrouum-brasil-que-ainda-pulsa-e-se-atualiza-diante-de-nos.shtml. Acesso em: 03/01/2017.

${ }^{2}$ Idem
} 
governo Lula vislumbrou a saída para a situação de país periférico marcado pelo atraso político, social e econômico. Em ambas as situações, a miragem se desfez e permanece a pergunta título da canção Isto aqui o que é?

O episódio da abertura das Olimpíadas ilustra com clareza a força cultural da canção ao longo do século XX. Isso já seria suficiente para indicar que, nas canções, há uma rica fonte de representações a respeito do Brasil. Mas não apenas a respeito daquilo que o Brasil é e sua possível identidade. A canção popular, sobretudo após a bossa nova, colocou em circulação representações de um Brasil moderno, novo: um país que será, seria, poderia ter sido. Tanto na bossa nova quanto na tropicália e nas canções de protesto dos anos 1960, é manifesto o desejo de trazer a ideia de um Brasil moderno e os desafios que ela implica para dentro da canção, seja na forma, seja no conteúdo. A bossa nova, como aludido no evento da abertura das olimpíadas, assumiu o desafio de representar uma modernidade brasileira idílica, leve, sofisticada. Isso não apenas no conteúdo das letras, como também na própria forma das canções que, utilizando procedimentos composicionais sofisticados, indicavam caminhos para a superação da "fase da exportação de matéria prima"3 para um produto estético complexo, o qual lograva incorporar o que havia de mais avançado em técnica estrangeira com a identidade e o balanço da canção popular brasileira. A tropicália, por sua vez, assumindo um gesto oposto e complementar ao da bossa nova ${ }^{4}$, não buscou a integração, mas sim o choque, a contraposição brusca entre a estética pop internacional dos anos 1960 (sobretudo aspectos da contracultura presentes no trabalho dos Beatles e de Jimmy Hendrix) e elementos do Brasil "arcaico". Já no conteúdo das letras, ela também explorava os choques e fricções da modernização brasileira e da permanência de aspectos "arcaicos": a miséria, violência, autoritarismo. O Brasil novo aparecia então em sincronia com os elementos que buscava superar. Ao mesmo tempo, a canção de protesto dos anos 1960 era parte de uma cultura política de esquerda "nacional popular", na qual os elementos arcaicos seriam passíveis de superação a partir da luta e pedagogia política.

Esses momentos da canção popular do final dos anos 1950 até o final dos anos 1960 (os quais recuperam e atualizam a tradição da canção estabelecida nos anos 1920 e 1930) já foram objeto de inúmeros trabalhos acadêmicos, além de terem sido canonizados como ícones da cultura nacional. Isso se mostra, por exemplo, no caso de Tom Jobim, cujo nome foi prestigiado com honras estatais, batizando aeroportos, salas de concerto, avenidas e universidades de música. Outros nomes, como Caetano Veloso e Chico Buarque, são até

\footnotetext{
${ }^{3}$ Fragmento da declaração de Tom Jobim por ocasião do show de lançamento da bossa nova no Carnegie Hall, em 1962. Citação na íntegra na abertura do capítulo VI.

${ }^{4}$ Cf. Luiz Tatit. O Século da Canção. São Paulo: Ateliê Editorial, 2004.
} 
hoje figuras de grande prestígio e sempre presentes no debate público nacional, sobretudo o primeiro escreve frequentemente em colunas de diversos jornais. Que o nome e as opiniões de cancionistas tenham tamanha relevância na cultura nacional, é indicativo da importância que essa forma de comunicação assumiu ao longo do século XX.

No entanto, a partir do recrudescimento da ditadura nos anos 1970 e da crise econômica que atingiu o mercado fonográfico nos anos 1980, algo mudou para os novos artistas que tentaram não apenas produzir canções, mas também assumir o desafio de representar o Brasil moderno a partir das questões sedimentadas nesses momentos anteriores. Embora os nomes consagrados nos anos 1950 e 1960 mantivessem e ainda mantenham o prestígio e a importância no debate cultural, tornou-se cada vez mais difícil para os novos aspirantes conquistar a posição de cancionista-intérprete do Brasil. Certo que muitos outros artistas surgiram e continuam a surgir, mas grande parte deles se consagra como representantes de gêneros específicos da canção, ao passo que aquela posição anterior, que concentrava prestígios e capitais distintos, de alguma forma ficou mais rara. A quantidade de trabalhos acadêmicos, livros, crônicas, documentários e programas televisivos dedicados à bossa nova, tropicália e aos festivais da canção testemunham, mais uma vez, a posição singular que aquelas vertentes da canção alcançaram no período. Nas décadas posteriores, também a temática do Brasil moderno trabalhado a partir da problemática sedimentada anteriormente (pela síntese, pelo choque ou pela pedagogia política) perdeu progressivamente a centralidade no circuito de representações, na rede de recados construída pela canção.

No final dos anos 1970 e no início dos anos 1980, surgiu a figura excêntrica de Arrigo Barnabé, parte de um movimento mais amplo chamado vanguarda paulista. No seu álbum de estreia, Clara Crocodilo, ele buscou radicalizar o gesto tropicalista de choque, tanto na forma das canções, quanto no conteúdo, ao mesmo tempo que recuperou tentativas de sínteses, como a da bossa nova, e a tematização do popular tão presente nas canções de protesto. O álbum apresenta retratos urbanos violentos e distópicos, contrapondo-se radicalmente a todos os aspectos positivos atribuídos à ideia de um Brasil moderno, em momentos anteriores da canção popular.

Este trabalho tem por objetivo analisar o álbum Clara Crocodilo, partindo da percepção de que ele concentra um grande volume de informações a respeito da canção popular brasileira, das representações que ela fez sobre o que seria "modernidade nacional", dos modos como tematizou o popular, bem como das reflexões feitas sobre o desenvolvimento das formas da canção. Basta aprofundar um pouco a "genealogia" musical 
de Clara Crocodilo e se descortinarão várias "linhas" da dinâmica cultural da canção brasileira, da sua voz na esfera pública, do seu papel na criação e circulação de representações a respeito da identidade nacional e das contribuições da canção para a ideia de um Brasil moderno.

Nosso intuito é focalizar a temática da modernidade brasileira, tal como ela é representada nessas canções, assim como quais são as intertextualidades que se podem encontrar: quais outros momentos da música popular brasileira e da música erudita são evocados? Quais deslocamentos, diferenças ou mesmo discrepâncias existem entre as canções de Arrigo Barnabé e aquelas com as quais ele dialoga? Quais sentidos diferentes atribuídos à modernidade nacional podem ser lidos em suas canções? Estamos interessados no modo como essas representações apontaram não apenas o Brasil real, mas também outras dimensões nelas implicadas: o modo como as canções apontaram direções para o novo, direções do vir-a-ser da ideia/do ideal de modernidade brasileira.

O interesse em Barnabé provém do retrato que ele realiza da cidade de São Paulo em sua face violenta, obscura e degradada, algo até então incomum na temática da canção, muito embora posteriormente, com o advento do rap nacional, nos anos 1990, a temática da violência urbana, da exclusão social e da miséria tenha adentrado a canção de uma vez por todas. O que distingue Barnabé dos artistas do rap é a posição a partir da qual ele produziu suas obras. Ele ocupou uma posição social semelhante àquela dos compositores da bossa nova, da tropicália, das canções de protesto: artistas oriundos de frações da classe média que tentaram falar, em determinados momentos, para o povo e pelo povo.

Mas ao contrário dos grandes nomes da MPB, Barnabé, assim como seus companheiros de geração da vanguarda paulista não obteve reconhecimento em âmbito nacional; sua obra permaneceu como referência apenas para um restrito público universitário e de aficionados da canção. Esses artistas também não obtiveram o mesmo apoio das grandes gravadoras como os grandes nomes, nem conseguiram penetrar nas "estruturas" da indústria musical e da grande mídia, permanecendo numa posição independente, com possibilidades restritas de colocar suas obras em circulação. Conforme pretendemos argumentar, a posição independente de Barnabé e dos grupos da vanguarda paulista, seu sucesso restrito, bem como o retrato amargo da modernidade nacional tal como experimentada numa grande cidade, são sintomas de uma transformação na posição social ocupada pela canção popular, bem como do cancionista oriundo de estratos da classe média. As canções de Clara Crocodilo denotam o fim de certo otimismo e encantamento com as aspirações por uma modernidade brasileira, 
e da dificuldade crescente da canção herdeira das posições estéticas e políticas dos anos 1960, de articular um discurso totalizante a respeito do Brasil.

No primeiro capítulo faremos uma apresentação de Arrigo Barnabé e dos grupos que compuseram a Vanguarda Paulista, suas canções, principalmente aquelas que tematizam a cidade de São Paulo, bem como o circuito independente que esses artistas formaram. O objetivo do capítulo é elucidar que papel esses artistas acreditaram exercer na dinâmica cultural da canção popular, bem como o que havia de problemático, ou até mesmo de ilusório, nessa posição. Pretendemos mostrar também em que medida esses artistas, sobretudo Arrigo Barnabé, estavam influenciados pelo aparato crítico sobre a canção que se consolidou em torno da tropicália, em especial os artigos reunidos no volume O balanço da bossa e outras bossas, de Augusto de Campos. Nesses artigos encontramos quase a totalidade das referências culturais que nortearam a composição das canções de Clara Crocodilo, em especial a ideia de uma "linha evolutiva" da canção popular, bem como a ideia de fazer a revolução pela forma.

No segundo e terceiro capítulos é realizada a discussão teórica deste trabalho. Uma vez que nos propomos uma análise sociológica da canção popular tendo como objeto a própria canção, começamos com uma revisão a respeito da canção enquanto objeto de interesse teórico, o que nos levou a uma revisão da semiótica de Luiz Tatit. Esse autor realizou, provavelmente, a mais ampla e profunda análise da canção popular brasileira, forjando seus conceitos pela análise de um amplo corpus de canções nacionais, o que torna o seu trabalho especialmente importante para qualquer interessado nesse objeto de estudo. Já no terceiro capítulo, procuramos realizar um contraponto à análise semiótica, ao refletir sobre a canção enquanto prática cultural, e não apenas como texto. Ou seja, para além dos significados investidos na canção enquanto forma portadora de sentido (texto), procuramos pensá-la enquanto uma prática na qual sentidos são criados, partilhados, postos em circulação e mobilizados por atores concretos em suas práticas cotidianas: ou seja, a passagem da gramática às práticas. Com isso em mente, mobilizamos conceitos de Erving Goffman para uma análise sociológica da canção, o que nos possibilita pensa-la a partir do agenciamento de material expressivo que, assim como nas representações da vida cotidiana, procura manipular a impressão da plateia e criar determinadas representações sociais de tipos e papéis.

A partir de um questionário de análise elaborado ao final do terceiro capítulo, partimos, então, no seguinte, para uma análise detalhada do álbum Clara Crocodilo. 
Analisamos canção por canção, interessando-nos em observar como melodia e letra constroem cenas, quais os tipos (sociais) de personagens construídos e quais são os valores associados a personagens e cenas. Torna-se claro que a representação sombria da cidade de São Paulo é sobretudo ambígua: atração e repulsão, desejável e abjeto misturam-se numa excitação sádica diante dos antros sujos, da violência e da prostituição.

No entanto, devido ao volume de informações concentrado nesse álbum, essa representação de cenas urbanas obscuras e sádicas adquire sua plena significação quando vista a partir da história da MPB. Partimos então nos quatro capítulos seguintes para uma revisão de momentos chave da canção brasileira, procurando elucidar a posição que ela adquiriu na cultura do Brasil, quais os sentidos por ela investidos na ideia de modernidade nacional, e a forma como o povo figurou nessas representações. $\mathrm{O}$ capítulo $\mathrm{V}$ discute a ascensão do samba à categoria de música nacional por excelência, nos anos 1920 e 1930, e da importância que ele conquistou para a canção popular enquanto forma artística brasileira e popular por excelência. O capítulo VI salta diretamente para a bossa nova, onde analisamos de que maneira ela sintetizou elementos composicionais estrangeiros e nacionais, bem como articulou um ideário modernizante na canção popular, procurando realizar, na esfera da canção, o salto modernizante então em voga nos anos de Juscelino Kubitschek. No sétimo capítulo, revisamos a canção de protesto no âmbito dos grandes festivais da canção dos anos 1960, a ideologia do nacional popular propagada pelos Centros de Cultura Popular (CPCs), bem como a estruturação do mercado fonográfico nas décadas posteriores. O oitavo capítulo aborda a tropicália e sua estética, na qual o choque entre o arcaico e o moderno surge como imagem de um Brasil mítico: modernização e miséria estariam inscritas no arquétipo brasileiro, assim como um destino de grandeza inédita também faz parte do sebastianismo tropicalista propagado por Caetano Veloso.

No último capítulo, retornamos a Barnabé, onde voltamos à questão lançada no samba de Ary Barroso "Isto aqui o que é?", quais os sentidos investidos na ideia de Brasil moderno na mais popular e mais difundida linguagem artística brasileira, a canção? Qual é a crise que se articula nas canções desse álbum? O que o "gosto amargo" do futuro está tentando nos dizer? 


\section{Capítulo I: Arrigo Barnabé e a Vanguarda Paulista}

O objetivo deste primeiro capítulo é apresentar Arrigo Barnabé e o contexto social (estudante universitário, originário do Paraná, na cidade de São Paulo) político (últimos anos da ditadura) e artístico (músico independente na chamada Vanguarda Paulista) no qual ele produziu sua obra mais marcante: o álbum Clara Crocodilo. Pretendemos mostrar algumas especificidades da representação da cidade de São Paulo presente nesse álbum, a qual funciona paralelamente como uma articulação - crítica - do processo de modernização da sociedade brasileira e do papel da canção popular como veículo de expressão desse processo. Como pretendemos mostrar também, essa representação articula aspectos dos contextos mencionados acima: da situação de músico independente num momento de crise econômica e do mercado fonográfico, em que se insinua o fim da ditadura civil-militar (mas em que o peso da censura e do autoritarismo ainda se faz sentir), e sobretudo um momento de reflexão sobre a história da música popular brasileira. Conforme tentaremos mostrar ao longo desta tese, as canções de Clara Crocodilo realizam uma revisão crítica da história da MPB, do engajamento político sob o paradigma do nacional popular, do diálogo com a música erudita e das inovações formais na canção, e de como a ideia de modernidade brasileira foi articulada pela canção popular. Comecemos com o percurso do compositor e sua relação com a cidade de São Paulo.

\section{Arrigo Barnabé e São Paulo}

Arrigo Barnabé ${ }^{5}$ entrou para a história da música brasileira ainda jovem, quando, em maio de 1979, recebeu o prêmio de melhor música no Primeiro Festival Universitário da TV Cultura de São Paulo, com a apresentação de Diversões Eletrônicas ${ }^{6}$. Nascido no dia 14 de setembro de 1951, Arrigo Barnabé é natural de Londrina, Paraná. Sua primeira formação intelectual e artística deu-se no Colégio dos Irmãos Maristas e no Conservatório Musical Carlos Gomes, também em Londrina. O artista cresceu, portanto, em um ambiente "tradicional", educado na fé cristã e com uma formação musical erudita. Não obstante, ele sofreu o impacto da canção popular brasileira, que, no final da década de sessenta, passou por um processo de intensa transformação, conhecido por Tropicália:

5 Discografia de Arrigo Barnabé: Clara Crocodilo (1980), Tubarões Voadores (1984), Cidade Oculta (1986), Suspeito( 1987), Façanhas (1992), Coletânea 25 anos de Clara Crocodilo (2004).

${ }^{6}$ BARNABÉ, Arrigo. Diversões Eletrônicas, I Festival Universitário de Música Brasileira da TV Cultura. Disponível em: https://www.youtube.com/watch?v=WrfL1ZOjNxM. A obra de Arrigo Barnabé conta com seis álbuns: Clara Crocodilo (1980), Tubarões Voadores (1984), Suspeito (1987), Façanhas (1992), Gigante Negão (1998), A saga de Clara Crocodilo (1999), além de trilhas sonoras e até mesmo missas. No entanto, segundo a crítica e o próprio compositor, o seu álbum de estreia é o seu trabalho mais interessante, e é nele que centraremos nossos esforços. [É necessário repetir a discografia, que já está na nota 5?] 
Eu sou filho da Tropicália. Sem ela eu não existiria. Na época eu ouvia as músicas de Caetano e Gil e ficava me perguntando: se eles faziam inovações na letra e no arranjo, por que não faziam na música também? Por que não alteravam os compassos, por exemplo? E aí fiquei achando que ousar na estrutura da música seria o próximo passo na evolução da música popular brasileira. Foi uma coisa pensada, premeditada mesmo. Nada de inspiração espontânea. (Apud OLIVEIRA, 1999, p. 64)

Assim, já na adolescência começou a delinear-se um traço fundamental da sua obra: a mescla e a coexistência de diversas linguagens musicais no mesmo espaço. Pois se, por um lado, a música erudita das vanguardas do início do século $\mathrm{XX}$, promovida por figuras como Arnold Schöenberg, Alban Berg, Anton Webern ${ }^{7}$, Bela Bartók ${ }^{8}$, Stravinsky ${ }^{9}$ e Stockhausen $^{10}$, fazem parte da linguagem musical explorada por Arrigo, as canções de Caetano Veloso, Gilberto Gil, Tom Zé e Tom Jobim são referências igualmente fundamentais da sua criação. Foi assim que, num esforço de ligação entre a linguagem musical erudita mais avançada com a tradição da canção popular brasileira, Arrigo realizou, em 15 de novembro de 1980, no auditório da Faculdade de Arquitetura e Urbanismo da USP, o show de lançamento do seu primeiro álbum, Clara Crocodilo. Alavancado pela notoriedade conquistada com o prêmio do Festival da TV Cultura, seu álbum de estreia foi recebido pela imprensa como a maior novidade da música brasileira desde a tropicália ${ }^{11}$ :

Em 1981, a Associação Brasileira de Produtores de Discos elegera Arrigo Barnabé "a personalidade do ano". No mesmo ano, Egberto Gismonti afirmara: "É genial. Não há ninguém no mundo fazendo o que ele faz". Em 1985, José Miguel Wisnik chamou-o "um outro Tom, o nosso Tom atonal" (GARCIA, 2015, p. 15)

\footnotetext{
${ }^{7}$ Arnold Schoenberg (1874-1951) e seus alunos Alban Berg (1885 - 1935) e Anton Webern (1883 - 1945) formaram a Segunda Escola de Viena. Marcaram a história da música com a introdução de novas linguagens musicais, como o serialismo e o dodecafonismo, as quais provocaram uma grande ruptura com a linguagem musical do século XIX.

${ }^{8}$ Bela Bartók (1881-1945) foi um compositor e pianista húngaro, pioneiro na etnomusicologia. Pesquisou e gravou músicas do folclore da Europa central (sobretudo da Hungria), das quais incorporou aspectos em sua obra. Também se destacou no esforço de superar a linguagem musical dos séculos XVIII e XIX.

${ }^{9}$ Igor Stravinsky (1882-1971), foi compositor russo, naturalizado francês. Ao lado de Schoenberg, foi uma das figuras mais importantes da música erudita do século XX. Mas, ao contrário deste, que explorava sobretudo os aspectos harmônicos e melódicos da música, Stravinsky notabilizou-se pelo uso de novas formas rítmicas.

${ }^{10}$ Karlheinz Stockhausen (1928-2007) foi compositor alemão, pioneiro na música eletroacústica e aleatória.

${ }^{11} \mathrm{Cf}$. André Cavazotti, O serialismo e o atonalismo livre aportam na MPB: as canções do LP Clara Crocodilo de Arrigo Barnabé. IN: Per Musi On line - Revista Acadêmica de Música. Belo Horizonte, V1, 2000.
} 
Clara Crocodilo é obra inspirada nas linguagens do cinema e das histórias em quadrinhos ${ }^{12}$, que recupera canções das primeiras décadas do século XX e ao mesmo tempo procedimentos composicionais das Vanguardas europeias, também do começo do século, para realizar retratos de uma metrópole obscura, culminando na história de um office-boy transformado em monstro, por causa de um experimento malsucedido em um laboratório farmacêutico. Parte do aspecto transgressor dessa obra reside no próprio texto das canções, que retrata a grande metrópole, São Paulo, no seu lado mais obscuro, sujo e decadente, uma temática até então incomum na canção popular brasileira ${ }^{13}$. A cidade é apresentada com os seus "antros sujos" (Diversões Eletrônicas), os bares, o drive-in (Acapulco Drive In), os espaços da prostituição, etc. Tais espaços são habitados por personagens como a prostituta, seu freguês, o gigolô, uma viúva que se entrega ao álcool e ao sexo (Infortúnio), a menina pobre que se torna vedete (Office-boy), uma enfermeira (Clara Crocodilo) e, finalmente, o office-boy transformado em monstro. Cada uma das canções, com apenas uma exceção, ${ }^{14}$ narra um episódio dessa espécie de ópera urbana e atonal ${ }^{15}$.

Porém, os temas das canções de Arrigo Barnabé, ao mesmo tempo que diferem da temática até então comum da MPB, recuperam uma tradição de canções que retratam o urbano, como as de Adoniran Barbosa ${ }^{16}$, Paulo Vanzolini e Orestes Barbosa (MARRACH, 2011, p.108). Diferem, pois a urbanidade em seu aspecto degradado não era até então tema

12 Não por acaso, a capa do álbum foi feita pelo cartunista Luiz Gê, colega de Barnabé na Faculdade de Arquitetura e Urbanismo. No link postado em nota de rodapé acima, o registro da apresentação da canção Diversões Eletrônicas, vê-se uma entrevista com o compositor, na qual ele declara que uma de suas maiores inspirações á a linguagem dos quadrinhos. Exploraremos um pouco mais desse aspecto no capítulo "Escutando Arrigo".

${ }^{13}$ Bela apresentação e análise do disco é feita na dissertação de mestrado de Juliana BATISTA, de 2013, O universo de Clara Crocodilo: História e música no LP de Arrigo Barnabé (Pontifícia Universidade Católica do Rio Grande do Sul. Faculdade de Filosofia e Ciências Humanas. Programa de Pós-Graduação em História).

${ }^{14}$ Apenas a faixa Instante não narra nenhum episódio relacionado à saga de Clara Crocodilo.

15 Música atonal é um termo que se refere às composições contemporâneas que procuraram romper com o sistema tonal. Esse sistema, desenvolvido a partir da Renascença, estrutura as sete notas musicais em torno de uma nota fundamental, o tom, linguagem musical que continua até hoje a estruturar as canções populares, do rock ao jazz. Casos como o de Arrigo Barnabé, que buscou fazer música popular atonal, são extremamente raros.

16 "Nessa música [Office Boy], há um diálogo com Adoniran Barbosa. O Áurea Strip Show é o Cine Áurea, que fica no lugar onde estava a Saudosa maloca de Adoniran Barbosa; tem até uma placa no local dizendo que ela foi demolida para construir o cinema. É na rua Aurora, lá que tem o prédio do Áurea. E as duas músicas falam desse lugar da cidade. Arrigo conta que, quando estava compondo, procurou nos jornais a relação de nomes dos cinemas: 'eu sabia que tinha uns cinemas que tinham striptease naquela época. Eu acho que já tinha assistido um striptease naquele cinema, era um negócio inacreditável, assim, as mulheres eram horrorosas, faziam striptease antes de começar o filme, você não acredita! É aquele striptease super meia boca. Aí eu procurei no jornal e vi Áurea Strip Show e coloquei na música'." [É nesse lugar que a aspa simples fecha?]Sonia Sonia [O nome é repetido duas vezes?] Alem Marrach. Música e universidade na cidade de São Paulo: do samba de Vanzolini à Vanguarda Paulista. São Paulo: Editora Unesp, 2011, p.104. 
comum das canções populares. Houve um deslocamento com relação às figuras tradicionais da canção brasileira como a baiana, a morena, o malandro, para figuras ligadas a uma urbanidade mais sombria, a metrópole dos luminosos, do fliperama, da prostituta, do marginal, das diversões eletrônicas. Mas também recupera, uma vez que a canção Diversões Eletrônicas foi inspirada por Arranha Céu de Orestes Barbosa interpretada por Silvio Caldas. Arranha Céu serviu de inspiração para Diversões Eletrônicas, canção que foi peçachave na carreira de Arrigo Barnabé, uma vez que ela lhe rendeu o título de vencedor do primeiro Festival Universitário da TV Cultura de São Paulo e a projeção do seu nome na imprensa. A influência se faz perceber no uso da imagem dos luminosos, mas a cidade que se constrói a partir da observação do eu lírico, transforma-se em espaço degradado, em "antro sujo", conforme aparece na canção. O luminoso anuncia as palavras "Diversões Eletrônicas", ou seja, uma casa de jogos eletrônicos e fliperamas, muito comuns em São Paulo até a década de 1990, mas que perderam espaço para os jogos desenvolvidos para computadores pessoais. Em tais espaços de "diversões eletrônicas", era característico o ambiente saturado de luzes e sons artificiais, ambiente que é recuperado na atmosfera sonora da canção, onde as vozes femininas agudas e metalizadas, assim como as séries dodecafônicas provocam estranheza e desconforto nos ouvintes. Configura-se desse modo um deslocamento em relação ao modo como a canção popular tipicamente representava o espaço urbano e suas personagens:

\footnotetext{
Então você já tinha padrões que foram instituídos, vamos dizer assim, pelo Chico Buarque, pelos tropicalistas... E nós, eu e o Itamar [Assumpção], tentávamos fazer algo mais vivo. Para isso, observávamos bastante a cidade e o comportamento presente e passado da música popular. Tentávamos observar o que existia na história da música popular para, a partir disso, ficar mais claro o que sentíamos falta na música que estava sendo produzida naquele momento. (...) Quando eu escutei algumas coisas do Orestes Barbosa, principalmente "Arranha-céu”, vi que era uma coisa altamente urbana, em que o cara falava dos 'delírios nervosos/ Dos anúncios luminosos'. É isso que a gente está vivendo, e é uma coisa que o cara fez há não sei quanto tempo atrás... Então eu prestava atenção nisso e achava que tinha espaço para um trabalho mais rico. (ARRIGO apud GARCIA, 2015, p.14)
}

Ou seja, apesar do esforço do compositor de fazer uma obra de vanguarda, do uso de procedimentos composicionais incomuns, há um diálogo sempre presente com a canção popular ao longo do álbum. Não por acaso, numa performance em 2015, Arrigo Barnabé encenou o encontro do monstro Clara Crocodilo com um ébrio, que segurava um maço de flores nas mãos (referência à capa do álbum Nervos de Aço, de Paulinho da Viola, 1973), onde eles cantaram juntos a canção de Lupicínio Rodrigues "Nervos de Aço". O monstro 
dodecafônico se reconhece na figura do ébrio, boêmio e ciumento, personagens tão presentes em cancionistas como Vicente Celestino, Lupicínio Rodrigues e Paulinho da Viola.

\section{Vanguarda e racionalização}

Outro aspecto a conferir teor de "novidade" e "vanguarda" ao álbum de estreia de Arrigo Barnabé é a mescla que apresenta entre a moderna música dodecafônica erudita e elementos da canção popular brasileira. Desse modo, paralelamente ao texto que tematiza a metrópole e seus habitantes em sua faceta mais obscura e degradada, Arrigo Barnabé foi o primeiro compositor de música popular brasileira a utilizar sistematicamente os procedimentos seriais ${ }^{17}$ e dodecafônicos ${ }^{18}$ em suas canções. Esses procedimentos da música erudita originaram-se do esforço, sobretudo de Schönberg, de distorcer, desintegrar e desarticular a linguagem musical que se estabelecera anteriormente, a música tonal. Vê-se assim que, na música de Arrigo Barnabé, o retrato de personagens e lugares da cidade de São Paulo se articula com uma linguagem musical que afronta a sensibilidade do ouvinte acostumado à música popular brasileira, o que se afigura como uma atitude propositalmente provocativa do compositor: "A gente queria fazer uma música de que as pessoas não gostassem, mas que fosse bela. As pessoas a que estou me referindo são a alta burguesia, o chefe de polícia, a dona de casa caretona" (BARNABÉ apud CAVAZOTTI, 2000, p.?). Essa atitude provocadora não se restringia a afrontar os nichos sociais designados pelo compositor, pois também transgredia o senso comum do público de música erudita: "A gente queria fazer música erudita contemporânea, mas que pudesse ser tocada no rádio, com guitarra elétrica" (BARNABÉ apud CAVAZOTTI, 2000, p.?).

Poderíamos indicar um ponto central para pensar a relação de Arrigo Barnabé com as vanguardas europeias: o aspecto racional, a racionalização do processo de composição levado a cabo por compositores como Schoenberg, por mais absurda ou irracional que possa parecer a sua linguagem musical. O próprio Arrigo afirma que as suas peças não surgem espontaneamente, tudo nelas é pensado. Podemos mencionar aqui, como exemplo, o processo pelo qual ele chegou ao nome de seu álbum de estreia, Clara Crocodilo:

Quando escolhi o nome CLARA CROCODILO, lembro-me que tinha acabado de ler o poema Aura Amara, do trovador provençal Arnaut Daniel (em tradução de Augusto de Campos), no livro ABC da Literatura, de Ezra Pound, e estava com esse nome/som na cabeça. AURA AMARA.

\footnotetext{
17 O serialismo é uma técnica de composição, na qual o princípio de estruturação da música se funda numa sucessão preestabelecida e invariável de sons, portanto, uma série.

${ }^{18}$ Música dodecafônica é aquela composta com os dozes graus do sistema temperado (a divisão da oitava em doze intervalos iguais).
} 
Reparei que é uma palavra econômica, só possui, na verdade, quatro letras, o A, o $\mathrm{U}$, o R e o M e, eu queria um nome assim, mas que fosse, ao mesmo tempo também, a articulação de duas coisas opostas tipo, p. ex., PLUMAS E PEDRAS.

Aí me veio essa palavra CLARA, que representa luz, justaposta a CROCODILO, que representa coisa escura. Feminino/masculino. CLARA dá a idéia de luz, enquanto CROCODILO dá a idéia de pântano, de "lá no fundo", de "debaixo d'água", de coisa escura.

E havia CLA, depois CRO, uma simples troca de letras: o CL e o CR formando combinações. E eu queria experimentar essa coisa de combinação do som das palavras, como se fossem notas musicais. O R da palavra CLARA vai aparecer no $\mathrm{CRO}$ e, em seguida, vem o $\mathrm{C}$ de $\mathrm{CO}$, que, antes, já havia aparecido junto a uma consoante e as únicas letras que não se repetem são o D e o I, de DI, pois, em seguida, vem o L de LO, que já estava na palavra CLARA, e a vogal O, contida em toda a palavra CROCODILO. Isso tudo eu penso de modo consciente quando vou compor, minhas peças não surgem espontaneamente. (BARNABÉ, 1982)

Com esse procedimento metódico e racional de criação, Arrigo alinha-se diretamente com Schönberg. Pois, como argumenta Flo Menezes ${ }^{19}$, a música desse compositor é uma "hegemonia do pensado": "Compor, para Schönberg, é essencialmente pensar a composição: 'Compor é: pensar em sons e ritmos "',20. Segundo Menezes, as composições de Schönberg caracterizam-se pelo predomínio da racionalidade sobre a intuição no ato de concepção artística: “Tem-se em sua obra, então, o apogeu da racionalidade na música, sem que se abdique, contudo, da expressão." 21 Justamente esse apogeu da racionalidade da música estabelece o diálogo entre essa linguagem musical e a experiência social moderna a experiência do isolamento e da anomia social nas grandes cidades, tal como foi retratada por Arrigo Barnabé.

Podemos observar essa experiência da modernidade nas vanguardas musicais, pois aí o desenvolvimento racional da música e a sua alienação com relação à sociedade caminharam lado a lado. Schönberg e seus discípulos Berg e Webern formaram a segunda escola de Viena. A primeira foi composta por Haydn, Mozart e Beethoven. Nela, o sistema tonal encontrara o seu apogeu, erigira-se como sistema de referência comum. Essa estrutura da linguagem musical era partilhada pelos músicos e pelo público e por isso pôde tornar-se uma linguagem compreensível. Já na segunda escola, foi instaurada grande instabilidade na linguagem musical: "o Novo emergia como força motriz de toda e qualquer criação, cada vez mais individualizada e por vezes mesmo tendente a certa alienação esquizofrênica pela negação de qualquer paradigma comum.” (MENEZES, 2013, p. 145)

Ao contrário do sistema tonal, que estabelecera uma linguagem musical compartilhada, as inovações formais da segunda escola de Viena - o atonalismo, o

\footnotetext{
${ }^{19}$ Flo Menezes, compositor e professor da UNESP.

${ }^{20}$ Flo Menezes. Arnold Schoenberg e a hegemonia do pensado. In: ALMEIDA, Jorge ; BADER, Wolfgang (orgs). Pensamento Alemão no século XX. Vol. III. São Paulo : COSAC NAIFY, 2013.

${ }^{21}$ Idem
} 
serialismo e o dodecafonismo - criaram linguagens musicais altamente individualizadas, levando o compositor a isolar-se da sociedade, distanciando-se cada vez mais do seu público. Sem um sistema de referência comum, a compreensão dessas obras é cada vez mais dificultada. Ocorre, com o artista de vanguarda perante o seu público, o mesmo isolamento anômico do habitante das grandes cidades.

No entanto, devemos desde já explicitar que, mesmo tendo entrado em contato com os compositores eruditos desde os anos de conservatório, na infância, a grande inspiração no modo de articular linguagem erudita e popular, e até mesmo no conjunto de compositores e referências culturais que nortearam o trabalho de Barnabé, veio da leitura do livro O balanço da bossa e outras bossas, de Augusto de Campos, e, obviamente, da apresentação da tropicália que é feita nesse livro. A seguinte passagem do manifesto de Décio Pignatari Nova Poesia, inserida num artigo de Augusto de Campos que analisa a importância cultural da então recém surgida tropicália (“A explosão de Alegria Alegria” 1967), resume muito das referências incorporadas por Barnabé:

\footnotetext{
a importância do olho na comunicação mais rápida: desde os anúncios luminosos até as histórias em quadrinhos (...) a colaboração das artes visuais, artes gráficas, tipográficas. a série dodecafônica (anton webern) e a música eletrônica (boulez, stockhausen), o cinema. pontos de referência. (Pignatari apud Campos, 1967, p. 157, grifos nossos)
}

De fato, esses são pontos de referência da música de Barnabé (repare-se que até os "anúncios luminosos" aparecem nesse trecho!), o que já indica em que medida o seu contato com as vanguardas, e sobretudo a forma de usar esses procedimentos na música popular, foi mediado pela tropicália e pelo amparo crítico que ela encontrou nos poetas concretos paulistas (tema do capítulo VIII).

\section{São Paulo}

Em Arrigo Barnabé, a cidade de São Paulo é, ao mesmo tempo, o assunto principal das letras de Clara Crocodilo, ainda que apresentada em sua faceta mais negativa, e o espaço social que possibilitou o surgimento de um artista como ele, que chegou em 1970 à cidade para realizar seus estudos universitários, primeiramente em Arquitetura. Porém, ao entrar em contato com a vida cultural acadêmica, Arrigo decidiu abandonar a Arquitetura e 
ingressar no curso de composição da Escola de Comunicação e Artes. Portanto, a riqueza da vida cultural paulistana foi decisiva em seu percurso ${ }^{22}$.

Mas havia também o outro lado da moeda, pois na São Paulo de 1970 e 1980, o crescimento econômico e a diversidade cultural conviviam com a crise social, a degradação do espaço urbano, a escalada da violência, o alastramento das favelas e da marginalidade, cenário retratado no filme Cidade Oculta, cuja trilha sonora é feita pelo próprio Arrigo, e de cujo roteiro ele é coautor. Sua música também deve muito à experiência difícil de viver nessa cidade, como ele mesmo registra: "Outro dia eu estava pensando por que a minha música e a do Itamar [Assumpção] tem uma dose de agressividade que não se via em outros compositores da vanguarda paulistana. É que eu e o Itamar viemos do interior para São Paulo - e São Paulo para nós foi uma coisa muito agressiva. O impacto foi grande”. (BARNABÉ apud BRIGUET, 2010) $)^{23}$ Desse modo, Arrigo percebia como esse estilo de vida, solitário e agressivo, é uma condição imposta pela própria cidade, sobretudo para aqueles que não nasceram nela. Ele registra também como, ao longo dos anos, pôde observar as transformações no espaço social, que se dirigia cada vez mais para um estilo de vida individualista e solitário (Cf. BATISTA, 2013). Também o excesso de estímulos sensoriais, típicos da grande cidade, é um elemento presente em sua proposta estética, que, por vezes, apela ao kitsch e à ironia. Tudo isso conflui em sua linguagem musical, agressiva e urbana:

(...) a música de Arrigo apenas parece agressiva: de fato limita-se a tornar transparente a agressividade da realidade em forma - o processo de industrialização total por que passa a América Latina: internacionalizada e urbanizada em seus pontos nevrálgicos, só pode manter o ritmo de crescimento sobre a ruína de suas (boas ou más) tradições. (NAZÁRIO, 1983. p. 30)

Desse modo, há nas canções de Arrigo Barnabé um retrato sombrio da modernidade brasileira, tal como ela é vivida nas grandes cidades. Modernidade que se coloca em oposição exata àquela que foi cantada pela bossa nova, modernidade na qual mesmo a almejada libertação sexual, presente na atitude da tropicália, transmutou-se em mercantilização do sexo, como nas canções Acapulco Drive in e Orgasmo Total:

\footnotetext{
22 “'A FAU foi muito importante para mim, mais importante que a ECA, não tem comparação', diz Arrigo. Na turma de primeiro ano da FAU tinha todo mundo - havia fotógrafos, cineastas, autores de história em quadrinhos, músicos -, tratava-se de um ambiente cultural efervescente [...] Era um lugar onde, apesar da ditadura, tinha como trocar informação"'. Sonia Alem Marrach. Música e universidade na cidade de São Paulo: do samba de Vanzolini à Vanguarda Paulista. São Paulo: Editora Unesp, 2011, p.89.

${ }^{23}$ BRIGUET, Paulo. O que compõe Arrigo Barnabé. Entrevista de Arrigo Barnabé ao Jornal de Londrina (online), 20 de julho de 2010.
} 


\begin{abstract}
A modernidade de Arrigo, como a de Baudelaire, está na sua ligação com o submundo, a marginalidade, o underground, a Rua Aurora, o Áurea Strip Show, a zona de prostituição, o centro velho de São Paulo com o espetáculo da vida mundana das existências desordenadas, das prostitutas e dos criminosos vivendo nos submundos da grande cidade, convivendo contraditoriamente com o moderno: o supermercado, a TV, o jornal, o anúncio luminoso, o Playcenter, o drive-in, os enlatados, o bar com balcão de fórmica vermelha, o telefone público.
\end{abstract} (MARRACH, 2011, p.107)

Mesmo décadas depois do seu álbum de estreia, em 2012, Arrigo ainda refletiu sobre tais aspectos da vida em São Paulo, erigindo o rio que corta a cidade em metáfora dessa vida solitária, obscura e estagnada:

São Paulo é solidão. Lava que cobre tudo. Atravessar a ponte sobre o rio Pinheiros a pé, existe algo mais desolador que isso? [...] Olhando para baixo, podemos ver o rio que não corre mais. Antes piscoso, agora viscoso. Estagnado, aquela estagnação do hospital, da penitenciária, dos asilos. Nunca entendi porque ele aparecia azul nos mapas. E eu ali em cima, como um esganado, querendo retirar beleza daquilo. Pode haver alguma beleza nisso? (BARNABÉ, 2012)

Nesse cenário, no qual se desenvolve o enredo de Clara Crocodilo, a perspectiva de transformação recai sobre a figura do marginal. Em contraste com a música popular brasileira das décadas anteriores, que enaltecia o "povo" como o principal agente de transformação social, nas décadas de 1970 e 1980, o marginal aparecia como o principal antagonista da ordem estabelecida (Cf. FENERICK, 2003). O protagonista de Clara Crocodilo, apresentado na última faixa do álbum como "meliante", o "inimigo público número 1", o qual, encapsulado num disco empoeirado, vem trazer a angústia e o pânico para os lares burgueses, é justamente um marginal.

O monstro marginal que protagoniza as duas canções finais do álbum Clara Crocodilo é símbolo que sintetiza uma série de questões. Primeiramente, essa figura provoca um grande deslocamento com relação aos retratos que a MPB das décadas anteriores fazia do povo. Como veremos em capítulos seguintes, já nas décadas de 1920 e 1930, a representação do popular era um tema central da canção, representação que interessava às classes populares, em busca de legitimação social, e ao Estado Novo, em busca de legitimação política. Na Bossa Nova também há canções que retratam o povo numa espécie de elogio da dignidade da vida humilde (Maria Ninguém, Morena Rosa, Falsa Bahiana). Já 
nas canções de protesto, a figura do povo era a depositária de todas as virtudes e esperanças de emancipação política. Desse modo, é significativo das transformações sociais que surja na canção popular na década de 1980 uma representação tão sombria do povo e da modernidade brasileira, denotando um enfraquecimento das esperanças sociais que se haviam depositado na canção popular.

Mas o marginal de Arrigo Barnabé possui também uma função metalinguística, pois quem esteve "aprisionado por mais de 20 anos" num mero disco foi a sua própria música. A canção Clara Crocodilo remete ao esquecimento de si mesma, à falta de reverberação das produções independentes:

[...] de fato não havia maior prisão para uma obra fonográfica, na década de 1980, do que a sua inclusão em um disco fora do círculo gravadoras/meios de difusão em massa, por conta das consequentes má divulgação e péssima veiculação -, Clara Crocodilo guarda ali a sua ira e a sua violência, frutos da sua consciência em parte preservada. Enquanto aguarda sem ser ouvida, Clara é uma morta-viva, consciente mas inútil como pode ser um disco que não é tocado. E, assim que é ouvida, Clara se vinga, passa a ameaçar quem a libertou, ou seja, passa a ameaçar cada um de nós que a escutamos. Mas a composição dá uma guinada quando Clara, que nos atira sua munição musical, não consegue nos matar. Passamos a perseguir o monstro, que se esgueira em um labirinto musical. Podemos desejar-lhe a morte, mas temos de seguir Clara nesse labirinto. E ela foge. O desfecho da história retoma, em outro nível, o seu início. Nem o monstro consegue nos matar, nem conseguimos matá-lo. Se, entre o ano de 1980 e 31 de dezembro de 1999, Clara mantinha-se uma morta-viva, agora ela vive escondida. Para Arrigo Barnabé, ela se transformou em labirinto, ela é o labirinto musical, de onde continua a ameaçar seus perseguidores, ao mesmo tempo que lhes envia, ou melhor, que nos envia pedidos de ajuda. Existe como potência - mas não como ato. (GARCIA, 2015, p.24)

Portanto, a figura do marginal no álbum Clara Crocodilo abarca um amplo espectro de conotações simbólicas. Para além de um personagem, ela alude ao processo de degradação do espaço urbano que ocorreu simultaneamente à modernização capitaneada pelo regime militar, alude ao enfraquecimento das esperanças utópicas que a esquerda depositava na luta popular (aprofundaremos esse tema no capítulo VIII) e alude também à posição ocupada por Arrigo Barnabé e outros companheiros de geração no campo da música popular brasileira nos anos 1980. A qual, nas palavras de Garcia, existiu mais como potência do que como ato. Posição esta que pretendemos descrever nos próximos itens deste capítulo. 


\section{A vanguarda paulista}

Na década de 1980, surgiu na imprensa o rótulo "Vanguarda Paulista" para designar o trabalho de artistas como Arrigo Barnabé, Itamar Assumpção, Na Ozzetti, Vânia Bastos, Tetê Espíndola, e os grupos Rumo, Premeditando o Breque, Língua de Trapo, entre outros (FENERICK, 2003). Embora o rótulo esconda a diversidade de propostas estéticas desses artistas, bem como o fato de nunca terem formado um movimento artístico coeso e com objetivos partilhados, é possível identificar neles um traço comum. A Vanguarda Paulista foi uma produção musical levada a cabo por artistas oriundos do meio universitário paulistano que, contrariamente ao que era ensinado no departamento de Música da Escola de Comunicação e Artes, optaram pela canção popular ${ }^{24}$. Contrariamente também aos grandes nomes da MPB, não obtiveram o apoio das grandes gravadoras e, portanto, tiveram de criar um circuito independente de produção musical, no qual o teatro Lira Paulistana acabou de alguma forma se notabilizando, sendo objeto de um bom número de dissertações de mestrado a seu respeito ${ }^{25}$. Contrariamente também àquilo que era até então (1980) convencional na música popular, as canções da Vanguarda Paulista não cantavam o sol, o mar e o que havia de bom, nem tampouco faziam canções carregadas de sentimentos passionais. Trata-se de canções que são, em sua maioria, crônicas extremamente ácidas da vida em São Paulo, nas quais são apresentados personagens e situações até então incomuns na canção popular: os "antros sujos" de Arrigo Barnabé, o "Nego Dito" de Itamar Assumpção e o "Lava rápido de gente" do Premeditando o Breque, entre outros. Conforme pretendemos argumentar, as canções da Vanguarda Paulista são sintomáticas de um deslocamento no eixo de produção da canção popular, assim como os temas dessas canções denotam o fim do otimismo e do encantamento com as aspirações a uma modernidade brasileira.

Nesta caracterização, devemos começar questionando o rótulo Vanguarda Paulista, o qual surgiu na imprensa e possui pouco ou nenhum valor para a compreensão das propostas artísticas desses grupos. Os próprios artistas evidenciam um certo desconforto com o rótulo, como Arrigo Barnabé: "Sempre achei esse rótulo estranho, por terem caracterizado trabalhos tão diferentes como um movimento. Minha música era de vanguarda mesmo, mas eu não via

24 Concentrar-nos-emos aqui nos seguintes grupos: Grupo Rumo, Arrigo Barnabé, Itamar Assumpção, Premeditando o Breque e Língua de Trapo.

25 Dentre elas destacamos Em um porão de São Paulo (OLIVEIRA, 2002), Façanha às próprias custas: a produção musical da Vanguarda Paulista (FENERICK, 2007), De um porão para o mundo (GHEZZI, 2003). 
isso em grupos como o Premê, que sempre trabalhou com o humor, ou o Rumo, que se baseava no canto falado" (CALADO, 2000, p.?). Luiz Tatit, do Grupo Rumo, também não vê consistência nessa definição: "Para mim, é um rótulo parecido com outros, como Rock dos 80, que veio de fora para dentro. Não prejudicou, nem acrescentou nada" (CALADO, 2000, p.?). Hélio Ziskind, do grupo Rumo, argumenta que o nome talvez tenha decorrido de um engano por parte da imprensa que, ao saber que esses novos artistas vinham da Escola de Comunicação e Artes da USP, onde se ensinava e produzia música erudita de vanguarda, prontamente rotulou de vanguarda trabalhos que não se enquadravam nos mesmos parâmetros da universidade, posto que se tratava de canções populares (CASTRO, 2010). Portanto, o rótulo não ajuda muito na caracterização desses artistas, mas tornou-se obrigatório o seu uso, pois, desde a década de 1980, passou a ser assim designada essa movimentação musical paulistana. Como afirmou José Adriano Fenerick em Façanha às próprias custas, o rótulo possui função apenas nominativa, mas nenhum valor explicativo.

Ainda assim, seria também um erro não salientar os traços em comum que de fato existem nesses grupos. O primeiro deles é que (com a exceção de Itamar Assumpção) todos eram estudantes universitários e quase todos estudantes da Escola de Comunicação e Artes, da USP. Não deixa de ser surpreendente que estudantes desse departamento se tenham dedicado à produção de música popular: "Contrariamente a todas as expectativas que se poderia ter, dada a linha ideológica que marca o departamento de Música da ECA, a produção musical mais significativa de seus alunos se dá no campo da música popular” (MARTINS, apud FENERICK, 2007, p. 19). Outro traço comum, já mencionado, eram artistas que circulavam pelo mesmo espaço urbano e que enveredaram pelos circuitos alternativos de produção, como salienta Mário Manga, do Premeditando o Breque: "Todos se conheciam, até porque pertencíamos a um guetinho. Talvez o que mais nos unia era o fato de sermos todos independentes. Todos eram duros e não tinham vínculo com nada. Assim, a gente podia ousar, arriscar na música. Não tinha ninguém para segurar as rédeas”. (CALADO, 2000, p.?).

O depoimento acima ressalta que a situação "independente" desses artistas, então jovens universitários, teve consequências nas características propriamente estéticas desses grupos. O primeiro elemento a ser destacado é a centralidade que a cidade ocupa, ao mesmo tempo espaço de produção e tema de muitas canções. O próprio circuito independente de produção que se estabeleceu na cidade também é tematizado nas canções, como a Canção Bonita do Grupo Rumo. A presença do espaço e do circuito de produção nas canções alçou 
esses grupos a cronistas da cidade de São Paulo e da situação política do Brasil na década de 1980.

Luiz Tatit, integrante do Grupo Rumo e atualmente talvez o maior teórico da canção popular no Brasil, detecta o uso da fala como elemento comum nas canções da Vanguarda Paulista. Não por acaso, as pesquisas que Tatit viria a desenvolver no Departamento de Linguística da USP enfatizam justamente as relações entre canto e fala. É notório que o Grupo Rumo, Arrigo Barnabé e Itamar Assumpção, a partir da exploração técnica e interpretativa dos recursos presentes na fala cotidiana, romperam com as convenções da canção popular brasileira. Esse uso da fala ressonâncias possui similitudes com o Sprechgesang, o canto falado desenvolvido por Arnold Schönberg no contexto da Segunda Escola de Viena. No trabalho de intérpretes como Ná Ozzetti e Tetê Espíndola, fica evidente o nível de maestria técnica e radicalidade estética aos quais esses elementos foram alçados. Ou seja, realmente há elementos de vanguarda na vanguarda.

Além da tematização da cidade, da exploração da fala na canção e do aproveitamento de inovações da Segunda Escola de Viena na música popular, ainda deve ser salientada mais uma característica geral, antes da caracterização de cada grupo: todos eles buscaram vincular-se à tradição da Música Popular Brasileira e, ao mesmo tempo, foram influenciados pela noção de "linha evolutiva da MPB"; produziram motivados pela ideia de "dar o próximo passo" nessa linha evolutiva, criar a nova música popular.

A respeito da influência da ideia de uma "linha evolutiva" da MPB em seu trabalho, disse Arrigo Barnabé:

Foi o seguinte: na época, lá em Londrina, quando a gente já tinha uma preocupação com a linha evolutiva da MPB, (antes de conhecer a teoria de Augusto de Campos a respeito da linha evolutiva, a gente já tinha essa preocupação), a gente achava que depois do tropicalismo, que está ainda no tonalismo, o que tinha que acontecer era o atonal. Tinha que ter uma mudança na linguagem musical, porque a letra, os arranjos, tudo já tinha mudado, mas a linguagem não acompanhou aquilo. [...] A gente se perguntava por que esses caras não variavam o compasso, por que eles não compunham um negócio mais louco. Foi essa inquietação que me fez partir para esse lado. (Arte em revista, 1984, p. 23)

Pedro Mourão, do Grupo Rumo, revela uma postura semelhante: 


\begin{abstract}
Popular”. Não queríamos repetir as fórmulas criativas que estavam vindo. A ideia era evoluir... Era uma ideia clara de evolução criativa. Estávamos influenciados pela ideia de "linha evolutiva da MPB"... Quando fazíamos algo que se parecia com alguma música que já existia, nós não tocávamos. (OLIVEIRA, 2002, p. 65)
\end{abstract}

Aqui chegamos a um ponto crucial. Toda a produção da vanguarda paulista se dava num diálogo com as formas instituídas da MPB, em um esforço de "ir além" delas. Esse movimento todo certamente não existiria sem o precedente da tropicália, a qual também procurou revolucionar as formas estabelecidas da $\mathrm{MPB}$, trazendo à música popular um novo universo de referências culturais.

\title{
2.1 Tropicália e a ideia da linha evolutiva
}

A Tropicália veio a público em outubro de 1967, quando Alegria Alegria e Domingo no Parque foram lançadas no III Festival da Música Popular Brasileira da TV Record. Embora essas canções ainda não fizessem parte de nenhum movimento, ambas destoavam da tônica dominante da MPB e divergiam explicitamente dos critérios então dominantes de "brasilidade" (FAVARETTO, 1996). Ambas davam expressão a uma sensibilidade estética moderna, urbana, do universo cultural da juventude de classe média, aglutinando referências, da política, do cotidiano, do consumo, ao mundo do espetáculo: "bomba e Brigitte Bardot". Coube à imprensa transformar essa nova postura estética em "movimento", valendo-se das sempre prolixas declarações de Caetano Veloso e Gilberto Gil. A postura desses artistas se orientava pelo esforço de desconstruir as formas então vigentes da canção popular brasileira, justapondo-lhe referências as mais diversas: desde o mundo hippie, psicodélico, pop, aos elementos mais arcaicos da cultura brasileira. Entretanto, segundo os próprios compositores, essa atitude visava também desconstruir as interpretações então vigentes do Brasil (Cf. FAVARETTO, 1996, p.28).

Mas mesmo antes do surgimento dessas canções, Veloso e Gilberto Gil já faziam circular ideias a respeito das possibilidades de inovação formal na canção popular brasileira. Em maio de 1967, a revista Civilização Brasileira promoveu um debate sobre os caminhos da música popular brasileira; justamente nesse debate surgiu, pela primeira vez na imprensa, a noção de "linha evolutiva" da MPB, desenvolvida por Caetano Veloso, posteriormente divulgada e defendida por Augusto de Campos nos ensaios reunidos em O balanço da bossa. O teor do debate centrava-se nas questões da canção brasileira, a qual, conforme se pensava, 
estaria ameaçada pelas modas internacionais, personificadas pela Jovem Guarda ${ }^{26}$. A canção popular foi discutida dentro da contradição entre mercado e ideologia, entre qualidade e massificação. Quais as diretrizes para a veiculação de uma mensagem nacionalista e engajada que, ao mesmo tempo, fosse aceita pelo grande público? Nesse momento de ditadura militar, pré AI-5, ainda havia a esperança de que o poder poderia rapidamente voltar às mãos civis; na política formava-se a Frente Ampla (Lacerda, Kubitschek e Goulart) e o sucesso da MPB nos festivais alimentava a expectativa de "dinamizar o processo de resistência civil” (Napolitano, 2001 p. 124). Embora as esperanças políticas da MPB tenham sido rapidamente frustradas, a ideia de linha evolutiva tornou-se uma noção importante da canção nacional, exercendo influência decisiva nas gerações posteriores, sobretudo na Vanguarda Paulista.

Ainda segundo o trabalho de Marcos Napolitano, a questão que se colocava no debate da Civilização Brasileira era a conciliação entre o povo fonte e o povo destinatário, a conciliação de uma arte que, embora feita por uma elite, procurava recuperar as formas populares, sublimá-las esteticamente e apresentá-las. Mas o problema residia na questão: será a mensagem recebida pelo povo destinatário? Assim se manifestou um dos artistas presentes no debate: "A nossa maior contradição enquanto artista é a de pretender um desenvolvimento estético e formal para o qual o povo, a quem nos dirigimos, não está preparado" (NAPOLITANO, 2001, p.127).

Os músicos e intelectuais que, na década de 1960, procuravam salientar uma posição nacionalista e engajada para a música popular recorriam às ideias de Mário de Andrade: estilizar a arte popular e fazer da música um lugar de elevação pedagógica das classes populares, com a diferença de que, diferentemente da década de 1930, a pedagogia deveria agora incluir as pautas da esquerda (a politização popular tendo a canção como veículo “participante”). Foi contra esse posicionamento que Caetano Veloso lançou a noção de linha evolutiva da canção popular, segundo a qual a criação deveria guiar-se pela interlocução com as obras que compõem a tradição, com o intuito de recriá-la. Eis o trecho em que Caetano exprime a sua ideia:

\footnotetext{
A questão da música popular brasileira vem sendo posta ultimamente em termos de fidelidade e comunicação com o povo brasileiro. Quer dizer, sempre se discute se o importante é ter uma visão ideológica dos problemas brasileiros, e se a música é boa, desde que exponha bem essa visão; ou se devemos retomar ou apenas aceitar a
}

\footnotetext{
${ }^{26}$ Marcos Napolitano Seguindo a canção: engajamento político e indústria cultural na MPB (19591969). São Paulo: Annablume/FAPESP, 2001.
} 
música primitiva brasileira [...] Ora, a música brasileira se moderniza e continua sendo brasileira, à medida em que toda informação é aproveitada (e entendida) da vivência e da compreensão da realidade brasileira [...] Para isso nós da música popular devemos partir, creio, da compreensão emotiva e racional do que foi a música popular brasileira até agora; devemos criar uma possibilidade seletiva como base de criação. Se temos uma tradição e queremos fazer algo de novo dentro dela, não só temos que senti-la mas conhecê-la. É este conhecimento que vai nos dar a possibilidade de criar algo novo e coerente com ela. Só a retomada da "linha evolutiva" pode nos dar uma organicidade para selecionar e ter um julgamento de criação. [...] Aliás João Gilberto, para mim, é exatamente o momento em que isto aconteceu: a informação da modernidade musical utilizada na recriação, na renovação, no dar um passo à frente da música popular. (CAETANO apud NAPOLITANO, 2001, p.127)

Caetano colocava-se, portanto, em oposição às correntes que defendiam a folclorização e a pedagogia política pela via da canção [ou: por intermédio da canção], para defender uma música que se referia antes de tudo a si mesma. Ele lançava as bases para a busca de autonomização da canção popular:

\footnotetext{
Mas quando se começou a falar em bossa nova outra coisa tinha acontecido: o surgimento do cantor João Gilberto, em discos orquestrados por Jobim - lançando sambas do próprio, de Carlos Lyra, Vinícius de Morais, revivendo Caymmi e Ary e citando Orlando Silva - o surgimento de João Gilberto teve, musicalmente, um novo significado cuja importância independe do fato dele ter transferido a residência para Nova York [...] O jazz não é senão o enriquecimento da sua formação musical, um ensinamento de outras possibilidades sonoras, com os quais se está mais armado para compor, cantar e mesmo interpretar, criticar e redescobrir a tradição legada por Assis Valente, Ary Barroso, Orlando Silva, Vadico, Noel Rosa, Ismael Silva, Ciro Monteiro e o grande Caymmi. (CAETANO apud NAPOLITANO, 2001, p.131, grifos nossos)
}

A noção de linha evolutiva propõe que se conheça e sinta a tradição legada pelos cancionistas brasileiros para que seja possível produzir algo novo, mas organicamente ligado à tradição. Porém, é necessário nota que a posição assumida por Caetano no debate de 1967 já continha traços da tropicália enquanto vontade de ruptura e continuação da linguagem cancional brasileira. O gesto do tropicalismo, segundo Tatit (2004), configura-se como o oposto/complementar do gesto de triagem feito pela bossa nova. A tropicália colocou em funcionamento a mistura como princípio na moderna canção brasileira. A própria construção 
de uma canção como Alegria Alegria já aponta para o gesto de mistura pela sobreposição de temas e figuras nos versos, diferente das canções feitas até então, as quais se construíam com narrativas, quase sempre muito claras e lineares (pense-se em $A$ banda). A mistura propõe a assimilação e a justaposição (não hierarquizada) de referências e informações, o que contrastava bastante com a polarização característica dos anos da ditadura entre governo e oposição, direita e esquerda, cultura "imperialista" e "alienada" versus cultura "nacional popular" "revolucionária", canção de protesto e jovem guarda. Ou seja, a tradição a que Caetano se referia, e que deveria ser compreendida emotiva e racionalmente, incluía as mais variadas vertentes: "o tropicalismo deu a entender que a canção brasileira é formada por todas as dicções - nacionais ou estrangeiras, vulgares ou elitizadas, do passado ou do momento - e não suportaria qualquer gesto de exclusão”. (TATIT, 2004, p.103)

O grande legado da noção de uma "linha evolutiva" na canção popular, especialmente em se tratando de Arrigo Barnabé, foi a ideia de inovação e crítica social na forma da canção. Barnabé repetiu em inúmeras declarações e entrevistas a frase de Vladimir Maiakovski também tomada como lema pelos poetas concretos e pelos tropicalistas: "sem forma revolucionária não há arte revolucionária”. Essa noção - que inclui forma e conteúdo -, em se tratando da canção popular, deveria estar, segundo Veloso, organicamente ligada à compreensão racional e emotiva da nossa tradição da canção - esse era o feito de João Gilberto, esse era o triunfo que Barnabé e outros companheiros de geração almejavam.

Ainda a respeito da influência da tropicália sobre a Vanguarda Paulista, deve ser ressaltado que, para artistas como Arrigo Barnabé e o grupo Rumo, a Tropicália se apresentava como modelo de movimento musical inovador, contestador e bem-sucedido ${ }^{27}$. Ela era a referência de um movimento musical que havia logrado, ao mesmo tempo, o sucesso de público, o reconhecimento da crítica e o apoio financeiro e estrutural das gravadoras, sem comprometer as suas propostas estéticas. Nesse sentido, é possível entender o sentimento de fracasso em alguns artistas da Vanguarda Paulista ${ }^{28}$, pois eles conquistaram apenas um relativo sucesso de público e quase nenhum espaço nas grandes gravadoras, embora tenham sido saudados nos jornais como a grande novidade da MPB. Os músicos da vanguarda paulista jamais alcançaram o prestígio de nomes como Caetano Veloso e Gilberto Gil, os quais são até hoje reverenciados como artistas dotados de legitimidade para definir o que se chama de música popular de qualidade no Brasil.

\footnotetext{
27 A esse respeito, veja-se OLIVEIRA (2002) e FENERICK (2007).

${ }^{28}$ Cf. José Adriano Fenerick. Op. Cit.
} 
Essa posição dominante no campo musical foi o objetivo não alcançado pela Vanguarda Paulista. O sentimento de "fracasso" é um aspecto perceptível nos depoimentos desses artistas, colhidos em documentários como Lira Paulistana e a Vanguarda Paulista, de Riba de Castro, e Daquele Instante em Diante, longa-metragem de Rogério Velloso (2011) a respeito da trajetória de Itamar Assumpção. Nota-se que Itamar sempre almejou o sucesso de grandes nomes da MPB, mas não queria submeter-se aos ditames das grandes gravadoras, as quais já não ofereciam tanta liberdade estética aos novos artistas quanto àqueles da década de $1960^{29}$. O fato de não conseguir estabelecer-se satisfatoriamente para além de um círculo restrito de ouvintes gerou nele frustração que o acompanhou por toda vida $^{30}$. Também Arrigo Barnabé, no depoimento dado à Arte em Revista, deixa explícito o seu descontentamento com a falta de espaço nos grandes meios de difusão e alude que, com a ajuda deles, o seu trabalho poderia ter tido um alcance muito maior: "É burrice. Você vê. Clara Crocodilo, sem nenhuma distribuição, vendeu assim, cinco mil cópias. Agora imagine se tivesse distribuição nacional, com badalação, os caras descolando programas de televisão e tudo, ia vender pelo menos cinquenta mil cópias" (Arte em Revista, 1984, p.26).

A tropicália figurou então como um momento da canção em que inovação formal, engajamento político, popularidade e respeito da crítica caminharam juntos, o que a vanguarda paulista tentou de alguma forma atualizar. Embora não tenha conseguido o reconhecimento do público amplo e o sucesso financeiro e tenha-lhe faltado mesmo o amparo crítico da parte de intelectuais como o que a tropicália recebeu dos poetas concretos, restam à vanguarda paulista as canções e seu esforço de inovação formal, para o qual nos dirigimos agora.

\section{As universidades}

Que a vanguarda paulista tenha sido uma movimentação musical feita por universitários e para um público também majoritariamente universitário, e tenha existido num espaço "alternativo", próximo às universidades, traz questões interessantes a respeito desse espaço social de produção. A música popular é geralmente associada a espaços sociais que estão de alguma forma distantes dos recursos sociais mais valorizados, dos "capitais" econômico, social e simbólico. Como Tatit (2012) formulou, a atividade do "cancionista",

\footnotetext{
${ }^{29}$ Veja-se a esse respeito Walter Garcia. Clara Crocodilo e Nego Dito: dois perigosos marginais? Antíteses (Londrina), v. 8, p. 10-36, 2015.

${ }^{30}$ Veja-se a esse respeito os depoimentos de Suzana Salles no documentário Daquele instante em diante. Rogério Velloso, 2011.
} 
do produtor de canções, é muitas vezes vista como algo "natural" e espontâneo ${ }^{31}$, algo independente de saberes adquiridos em instituições de ensino, de modo que essa atividade pôde frutificar mesmo em espaços marginalizados: os morros, favelas e subúrbios, de onde provém grande parte das canções populares às quais é atribuída a áurea de "autenticamente popular"32.

Houve, porém, momentos em que a produção de canções se espraiou para espaços sociais mais "elevados", nos quais a atividade "popular" foi reivindicada por grupos escolarizados. Na história da canção brasileira, o momento mais emblemático desse deslocamento social talvez seja a Bossa Nova. Nesse movimento, tivemos músicos de formação erudita (Tom Jobim, por exemplo) e letristas com formação literária (Vinícius de Morais, por exemplo) que se dedicaram à canção popular e atingiram, num primeiro momento, um círculo de estudantes universitários interessados na apreciação dessa canção popular refinada (NAPOLITANO, 2001). Já nesse momento, as universidades serviram como centros aglutinadores de produtores que investiram diferentes informações estéticas num produto "popular" e de um público que possuía os capitais necessários para o consumo desses produtos. José Miguel Wisnik ${ }^{33}$ nota que, depois de Vinícius de Morais, poetas do livro passaram a circular pela canção popular: Jorge Mautner, Paulo Leminski, Waly Salomão, Antônio Cícero, Arnaldo Antunes, Alice Ruiz, Hilda Hilst.

Para a Vanguarda Paulista, a universidade forneceu não apenas os compositores, mas também boa parte do público que se interessou por suas obras. O sociólogo Howard Becker tece observações interessantes a respeito do papel dos estudantes no mundo das artes (BECKER, 1988, p.76). Para ele, os estudantes, principalmente aqueles que tiveram formação em algum domínio artístico, mas não conseguiram profissionalizar-se, compõem o público mais assíduo e tolerante com que um artista pode contar. São eles que conhecem melhor as convenções da arte, mesmo das formas mais experimentais, assim como são capazes de reconhecer o valor mesmo de uma tentativa fracassada, por já terem participado da produção de obras de arte enquanto estudantes. Esse é o público disposto a apreciar as experimentações mais audaciosas. Portanto, os aspirantes a artistas fracassados acabam por

\footnotetext{
31 "O dom inato, o talento antiacadêmico, a habilidade pragmática descompromissada com qualquer atividade regular são valores tipicamente atribuídos ao cancionista. Afinal, nunca se sabe exatamente como ele aprendeu a tocar, a compor, a cantar, parece que sempre soube fazer tudo isso. Se despendeu horas de exercícios e dedicação foi em função de um trabalho que não deu trabalho. Foi o tempo de exteriorizar o que já estava pronto." Luiz Tatit, O cancionista. São Paulo: Editora da Universidade de São Paulo, 2012.

${ }^{32}$ Veremos no capítulo II como essa "autenticidade" foi mais um capital em disputa no campo da canção popular, capital decisivo ao longo de todo o século XX.

${ }^{33}$ Em depoimento registrado no documentário Palavra (en)cantada. Helena Solberg 2008.
} 
tornar-se figuras de suma importância no mundo das artes, pelo apoio moral e financeiro que são capazes de dar às suas formas mais inovadoras.

No entanto, gostaríamos de sinalizar aqui, ainda que brevemente, que a produção de canções populares, nas quais são investidas muitas informações estéticas e que circulam para um público restrito é uma espécie de tradição na Universidade de São Paulo, que começou muito antes da Vanguarda Paulista e que persiste até os dias de hoje. Segundo Sonia Marrach $^{34}$, houve em São Paulo um casamento incomum entre pesquisa acadêmica e canção popular. Justamente no ambiente acadêmico paulistano firmou-se uma tradição de cancionistas em figuras que são, ao mesmo tempo, pesquisadores acadêmicos de expressão nacional e músicos populares. O primeiro deles foi Paulo Vanzolini, zoólogo de grande importância e um dos fundadores da FAPESP (Fundação de Amparo à Pesquisa do Estado de São Paulo), Que também foi sambista e compôs crônicas da cidade de São Paulo, por ele cantada de uma perspectiva sentimental e boêmia. Sua canção mais conhecida talvez seja "Ronda", escrita em 1945, quando o autor estava no exército e fazia, à noite, a ronda da cidade: "Naquele tempo, patrulha era a coisa mais mansa do mundo. Eu via uma mulher entrar num bar, procurar com os olhos, saía, chegava outra, procurava com os olhos, saía. Comecei a pensar: o que essas mulheres estão procurando?" (MARRACH, 2001, p. 37). A canção, fruto da observação da cidade, narra a busca de uma mulher à noite, de bar em bar, atrás do seu amado, mas angustiada por poder encontrá-lo nos braços de outra mulher.

Como sinal do deslocamento do espaço social de produção da canção popular para espaços sociais valorizados, no caso de Vanzolini, do samba - gênero tipicamente associado aos estratos sociais mais populares -, nenhuma canção melhor do que o Samba Erudito:

\footnotetext{
Andei sobre as águas

Como São Pedro

Como Santos Dumont

Fui aos ares sem medo

Fui ao fundo do mar

Como o velho Picard

Só pra me exibir

Só pra te impressionar

Fiz uma poesia

Como Olavo Bilac

Soltei filipeta

Pra te dar um Cadillac

Mas você nem ligou

Para tanta proeza

Põe um preço tão alto

$\mathrm{Na}$ sua beleza
}

34 Sonia Alem Marrach. Música e universidade na cidade de São Paulo: do samba de Vanzolini à Vanguarda Paulista. São Paulo: Editora Unesp, 2011. 


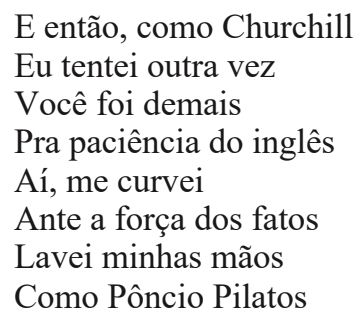

Além de Paulo Vanzolini, temos, é claro, os artistas que se destacaram na Vanguarda Paulistana. Diferentemente, em seu trajeto, muitos deles estudaram no Departamento de Música [ECA/USP], mas, assim como ele, destacaram-se na produção de canções populares, o que não era o senso comum do departamento. Mesmo depois da Vanguarda Paulista, a Universidade de São Paulo continuou a dar frutos na canção popular com José Miguel Wisnik. Formado em piano no conservatório de sua cidade natal, São Vicente, graduou-se em Letras na USP e defendeu sua tese sobre música na semana de 1922, sob a orientação de Antônio Cândido. Wisnik compôs canções de intenso lirismo como "Pérolas aos Poucos", mas também canções engajadas na questão urbana, feitas para o Teatro Oficina, como a "Inverno".

Altamente sugestiva desse duplo interesse pela canção, enquanto objeto de pesquisa e ao mesmo tempo enquanto prática artística, é a canção de Wisnik em parceria com Luiz Tatit, Mestres Cantores:

\author{
Nós aqui mestres cantores \\ Aprendizes felizes \\ Modestos e muito dignos \\ Da prosa da prosódia \\ Da prosápia da poesia \\ Da música popular \\ Da canção enquanto tal \\ Da música total \\ Da voz que fala \\ Pela fala e pela voz \\ Nós aqui livres docentes \\ Docemente livres \\ Entra o rap e o repente \\ A canção dolente \\ A canção e seu matizes \\ A música total \\ Da voz que fala \\ Pela fala e pela voz \\ E se a baiana escondeu no tabuleiro \\ $\mathrm{O}$ xadrez de estrelas de Vieira \\ E vai pondo em cada acarajé \\ A pimenta da fé \\ E o discurso engenhoso no tempero?
}




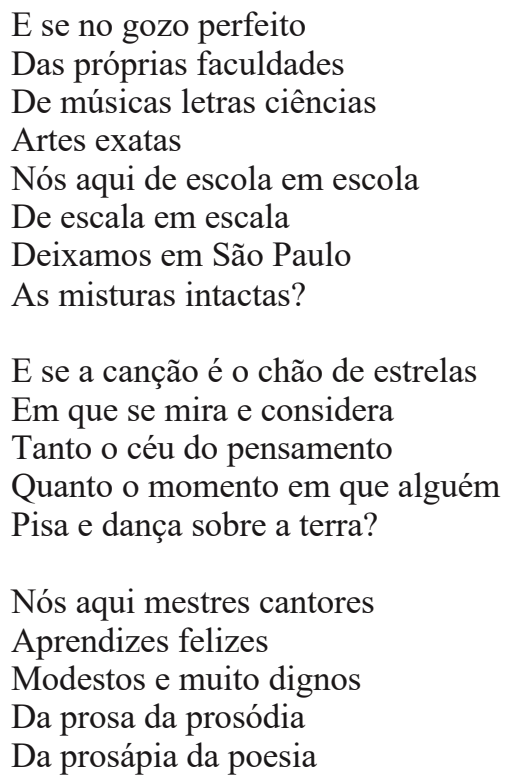

É interessante notar, como mostra a canção acima, que junto à tradição "prática" da canção na Universidade de São Paulo, firmou-se também, a partir dos anos 1980, na Faculdade de Filosofia, Letras e Ciências Humanas, um campo de estudos acadêmicos a respeito da canção popular, principalmente a partir dos trabalhos pioneiros de Luiz Tatit sobre a semiótica da canção. José Geraldo Vinci, Marcos Napolitano, José Miguel Wisnik, Walter Garcia são mais alguns nomes de pesquisadores que se dedicam à canção popular como objeto de pesquisa acadêmica, algo não tão comum em outras universidades brasileiras na época.

\subsection{Rumo ${ }^{35}$}

Aqui O Rumo era formado majoritariamente por estudantes da ECA-USP e, antes de tornar-se um conjunto de música, era um grupo de estudos e discussão sobre a música popular brasileira ${ }^{36}$. Formado em 1974 por Luiz Tatit, surgiu, entre outros motivos, em decorrência da falta de espaço para discussões sobre música popular dentro dos departamentos da ECA. Suas primeiras apresentações, que eram um misto de show e debate

\footnotetext{
35 Tanto neste item quanto nos próximos, faremos apenas a apresentação de algumas canções; a análise propriamente dita ficará para os próximos capítulos. Também demos preferência às canções dos discos de estreia desses artistas, por serem as obras lançadas durante a época da Vanguarda Paulista [Por que em letra minúscula?].

36 "Nos anos 1980 é que virou uma banda. O Rumo era composto por dez pessoas, quase todas da USP, o que não era um pré-requisito, coincidia por causa do coleguismo. Tatit estudava na ECA, seu irmão Paulo e o baterista Gal Oppido, na FAU. O Zecarlos Ribeiro estudava na Arquitetura de Mogi. Pedro Mourão fazia Música na ECA. Helio Ziskind era da Psicologia, pediu transferência e foi fazer Música na ECA. A Ciça Tuccori era da ECA." Sonia Alem Marrach. Música e universidade na cidade de São Paulo: do samba de Vanzolini à Vanguarda Paulista. São Paulo: Editora Unesp, 2011. p. 141.
} 
sobre música popular, foram em diversas faculdades da própria USP, no colégio Equipe e em outros espaços, como o Museu de Imagem e do Som.: "Nós ainda éramos muito amadores. Imagine que sofrimento causávamos ao público, parando toda hora para debater sobre música popular no meio de um suposto show... Com o tempo percebemos que ou discutíamos ou tocávamos... Paramos de ser tão cruéis com o público" (OLIVEIRA, 2002, p.30).

O sentido dessa postura "didática" do grupo, no sentido de trazer para as apresentações musicais a discussão teórica, decorre do esforço e da ambição de fazer parte da "linha evolutiva" da canção popular. O grupo pretendia apresentar aos ouvintes as bases teóricas da composição, que faziam de suas músicas uma novidade na linguagem da canção:

\footnotetext{
No fundo, queríamos fazer com canção popular algo na linha do que já existia na música erudita: fornecer ao público parâmetros para o reconhecimento das transformações propostas no nível da forma das composições. Isso pressupunha que todos deveriam conhecer a linguagem da canção para que pudessem detectar as novidades ali inseridas. Daí a razão dos debates e das constantes (e cansativas) explicações ao público do que estava acontecendo no palco. (TATIT, 2014, p.31)
}

Ao longo da década de 1970, o grupo enveredou pela pesquisa e reinterpretação de obras de autores antigos, já no esforço de sintetizar a canção popular brasileira: "De 77 a 79, o Rumo dividia seus shows em duas partes: na primeira, apresentava as músicas melhores e menos divulgadas do autor escolhido, na segunda, as composições do grupo”. (Arte em Revista, 1984, p. 12). Seguindo essa linha de trabalho, em 1981, o grupo lançou simultaneamente dois álbuns: o Rumo e o Rumo aos antigos ${ }^{37}$. O primeiro trazia composições próprias, e o segundo, reinterpretações de artistas como Noel Rosa, Lamartine Babo e Sinhô. A escolha desses artistas não era casual, partia da constatação de que as formas fundamentais da canção popular haviam se sedimentado na obra desses artistas, da geração de sambistas das décadas de 1920 e 1930 :

Isso decorria de um estudo sistemático que realizávamos da produção dos anos 1920 e 1930, período em que a canção popular havia atingido a maioridade e já apresentava as características das obras modernas. Esperávamos encontrar nesse repertório, digamos, mais puro, procedimentos essenciais de composição que

37 Discografia do grupo Rumo: Rumo(1981), Rumo aos antigos (1982), Diletantismo (1983), Caprichoso (1986), Quero passear( 1988), O Sumo do Rumo (1989), Rumo ao Vivo (1991). 
talvez estivessem menos explícitos nas músicas contemporâneas. (TATIT, 2014, p.31)

A partir da pesquisa dos sambas das décadas de 1920 e 1930, Luiz Tatit teve o insight que, daquele instante em diante, determinou sua carreira acadêmica. Trata-se da descoberta de que as melodias das canções não tinham origem na música, mas, sim, na entoação (TATIT, 2014, p.33). A entoação diz respeito à variação de altura (entre o grave e o agudo), realizada no momento da emissão de uma frase ou mesmo de uma única palavra. Na fala cotidiana, utilizamos diversos “desenhos" entoativos para transmitir nossos conteúdos linguísticos. Por exemplo, frases interrogativas perfazem um movimento que vai do grave ao agudo, valendo-se de uma terminação ascendente para indicar que a frase em questão é uma pergunta. Às inflexões que terminam as frases Tatit chama de tonemas (2012, p. 21), os quais são o ponto nevrálgico da sua significação. Eles possuem apenas três possibilidades físicas de realização (Idem): a ascendência (como vimos, usadas nas frases interrogativas), a descendência (usada nas frases afirmativas) e a suspensão (que prorroga a resolução da tensão). Ou seja, todo falante de um idioma possui a capacidade de manejar melodias (o projeto entoativo em suas frases), e essas melodias produzem ritmos de tensão e distensão na fala.

A tese de Tatit é que o cancionista opera a partir do saber adquirido no manejo da fala (a entoação), e não a partir de leis musicais (por esse motivo devemos denominá-lo de cancionista, e não de músico): “A 'audácia' de (...) compor melodias sem formação musical só pode se apoiar nas entoações naturais da linguagem oral” (TATIT, 2012, p. 22). A canção é uma forma artística que não se reduz nem à música nem à poesia, embora maneje elementos de ambas:

\footnotetext{
Mesmo que depois ganhassem tratamento musical do compositor ou do arranjador, tais melodias eram originalmente sugeridas pelas inflexões espontâneas das entoações da fala, cujo único compromisso é com as palavras simultaneamente pronunciadas. Ora, isso justificava a fecundidade de compositores totalmente despreparados do ponto de vista musical e literário. Desde Lamartine Babo até Zecarlos Ribeiro, passando por sambistas geniais semialfabetizados ou por notáveis acadêmicos, nada familiarizados com a leitura musical, como Paulo Vanzolini, a grande maioria dos compositores brasileiros tinha passado ao largo de qualquer formação em música. E, muitas vezes, sequer tocavam de ouvido um instrumento de apoio. (TATIT, 2014, p.35)
} 
Enquanto o conceito de entoação foi decisivo no pensamento de Luiz Tatit, a prática reflexiva desse conceito foi a orientação fundamental do Grupo Rumo, bem como do trabalho solo de Luiz Tatit e Ná Ozzetti. Mas não apenas. Para Luiz Tatit, o trabalho de Arrigo Barnabé faz uso recorrente da fala como elemento estético, vide as locuções radiofônicas que aparecem a todo momento no álbum Clara Crocodilo. Também Itamar Assumpção, ao explorar diversas linhas melódicas na canção, usou conscientemente diversos padrões de entoação. Em suma, para Tatit, sempre foi ela o germe da canção popular, desde os sambistas da década de 1920. O que distingue o trabalho do Rumo e de outros membros da Vanguarda Paulista, é o uso consciente desse recurso. É interessante notar que a entoação é vista pelo Rumo ao mesmo tempo como germe de toda canção popular e como o grande diferencial de seu grupo, pelo seu uso consciente e pelo esforço de borrar as barreiras entre canto e fala. Esse traço distintivo do Rumo, revelava-se em toda sua potência já nos primeiros trabalhos:

[...] a relação entre texto e melodia é a coisa mais pensada. A significação, o tipo de informação que a união destas duas coisas oferece é diferente da significação emitida só pela melodia, ou só pela música, ou mesmo a informação emitida só pelo texto poético ou linguístico. Assim, buscamos alguns recursos na própria fala que tem essas duas coisas, juntas naturalmente. [...] Uma canção sempre é alguém dizendo alguma coisa de alguma maneira. Dizer alguma coisa é o texto, de alguma maneira é a melodia. (Arte em revista, 1984, p.12)

A reflexão sobre as possibilidades de junção de melodia e letra, ao mesmo tempo em que trabalha com elementos da fala cotidiana e com a música popular, adquiriu características muito incomuns nesse trabalho, aproximando-o de aspectos da música erudita de vanguarda - a proposta do Rumo de aproximar o canto à fala e de borrar a barreira entre ambos é algo próximo ao canto falado desenvolvido por Schöenberg. Contudo, a proposta do Rumo não apenas se aproxima da obra desse compositor, como também abre possibilidades não exploradas por ele. Schöenberg desenvolveu o sistema dodecafônico, no qual os doze sons da escala ocidental são utilizados sem nenhuma organização hierárquica entre si. Já as canções do grupo Rumo, trabalhando a fala cotidiana, criam melodias microtonais:

Muitas vezes nós preferimos não fixar ou mesmo propor uma entoação no sentido tradicional porque, se você perceber, as músicas da gente têm notas muito precisas, são repetidas sempre do mesmo jeito. Se fosse só um texto falado, cada vez sairia 
um pouquinho diferente. Só que nós fixamos elementos que o Chico Buarque, por exemplo, não fixa, ou seja, micro tons, nuanças de voz. Há uma tradição na canção popular brasileira de se deixar tudo afinadinho, de nota para nota, meio em meio tom, temperar em resumo. E nós não estamos temperando. (Arte em revista, 1984, p. 13)

Portanto, curiosamente, foi o elemento mais prosaico que se pode imaginar, a fala cotidiana, que conferiu ao Rumo esse caráter vanguardista: "Se nós gravássemos a fala de alguém e extraíssemos a melodia, o resultado seria vanguardista, porque não há nenhuma regularidade." (MARRACH, 2011, p. 151). Diferente do canto lírico, onde a voz é pensada e trabalhada como um instrumento musical, na música popular, "a palavra é o elemento fundamental da construção do som e do sentido". (MACHADO, 2007, p. 16). O conceito de entoação refere-se ao modo como a fala se transforma em melodia, ao processo de extensão entre um e outro: "O nosso trabalho parte da possibilidade de extrairmos textos melodizados ou melodias textualizadas da fala cotidiana e repropô-las em forma de canção. [...] A exploração musical não é uma simples utilização de trechos da fala mas, principalmente, uma transformação estética desse material”. (TATIT apud FENERICK, 2007, p. 107)

\section{As canções do Rumo}

Uma vez que o germe essencial de toda canção está na união de melodia e letra promovida pela entoação, a apresentação de uma canção tão somente pela transcrição das letras é algo sempre empobrecedor ${ }^{38}$. Ainda assim, apresentaremos agora algumas letras do Grupo Rumo, com especial atenção pelo modo como elas retratam a cidade de São Paulo, ainda que por vezes indiretamente.

Em muitas canções de Luiz Tatit, o eu lírico do narrador apresenta-se como uma pessoa um tanto ingênua, com uma espécie de candura que, por contraste, serve de elemento para ressaltar a não-candura da cidade e de relações humanas. Desse modo, a aparente ingenuidade do eu lírico serve como senso crítico perante situações que o confrontam. Conforme observou José Miguel Wisnik:

\footnotetext{
O personagem-protótipo que a voz de Luiz Tatit encarna é o pierrô, aquilo que ainda possa haver de solitário, inocente, chapliniano, no habitante da metrópole mergulhado no mundo da concorrência. O indivíduo como cidadão irrisório, cuja dicção está inscrita no gesto original do samba carioca, em lírica ironia, e atravessa
}

38 Desse modo, convido o leitor a escutar essas canções do primeiro álbum do Grupo Rumo, (1981), disponíveis no youtube: https://www.youtube.com/watch?v=z2yUvTv0_Sg\&t=755s 
cheia de prosa e poesia a prosápia popular brasileira. (WISNIK apud FENERICK, 2007, p.155)

A canção Época de sonho é entoada por um narrador que, a rigor, não canta, apenas narra com as inflexões da linguagem coloquial uma situação sonhada, na qual o comportamento da mulher, que canta e dança, é visto como algo estranho, uma vez que "não é época de cantoria" nem "época de paixão". Apenas nos momentos em que imita o comportamento da mulher descrita a voz do narrador escapa da fala e produz o canto:

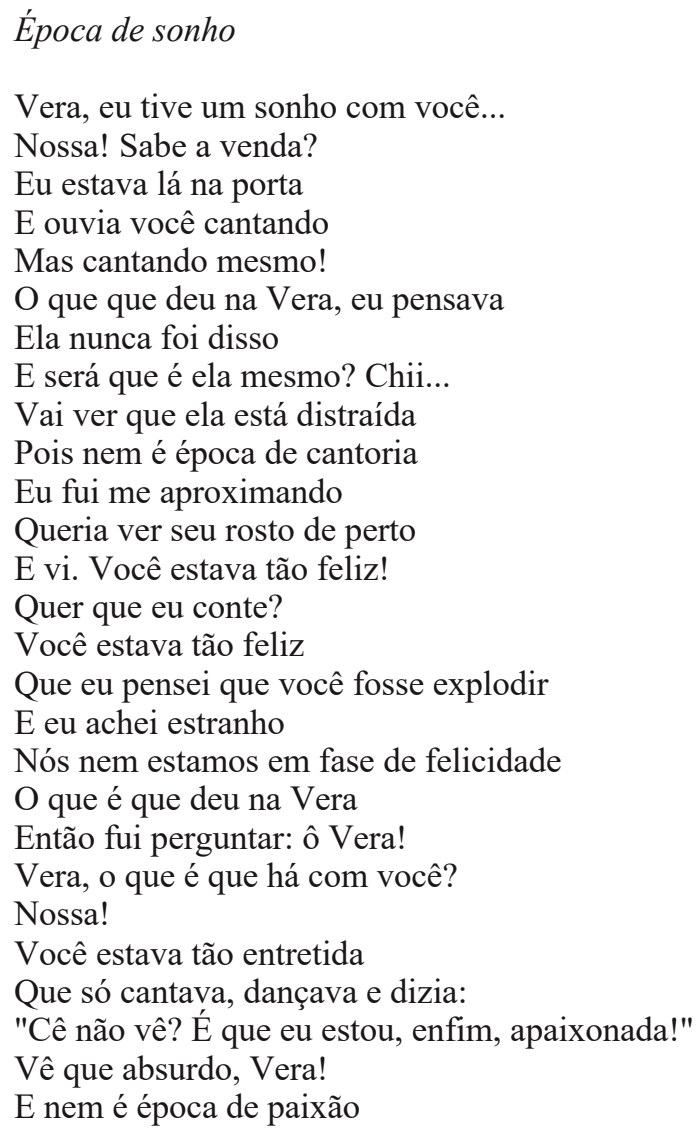

Na canção Acho Pouco, temos mais uma vez uma impostação de voz cândida, coloquial, mas que exprime uma fala um tanto estranha do eu lírico para a sua amada. A insatisfação com a relação é expressa num tom de banalidade, como se discutisse um assunto outro qualquer. O eu lírico procura convencer a amada a entregar-se "só um pouquinho" mais, como se tratasse de algo muito prosaico: 


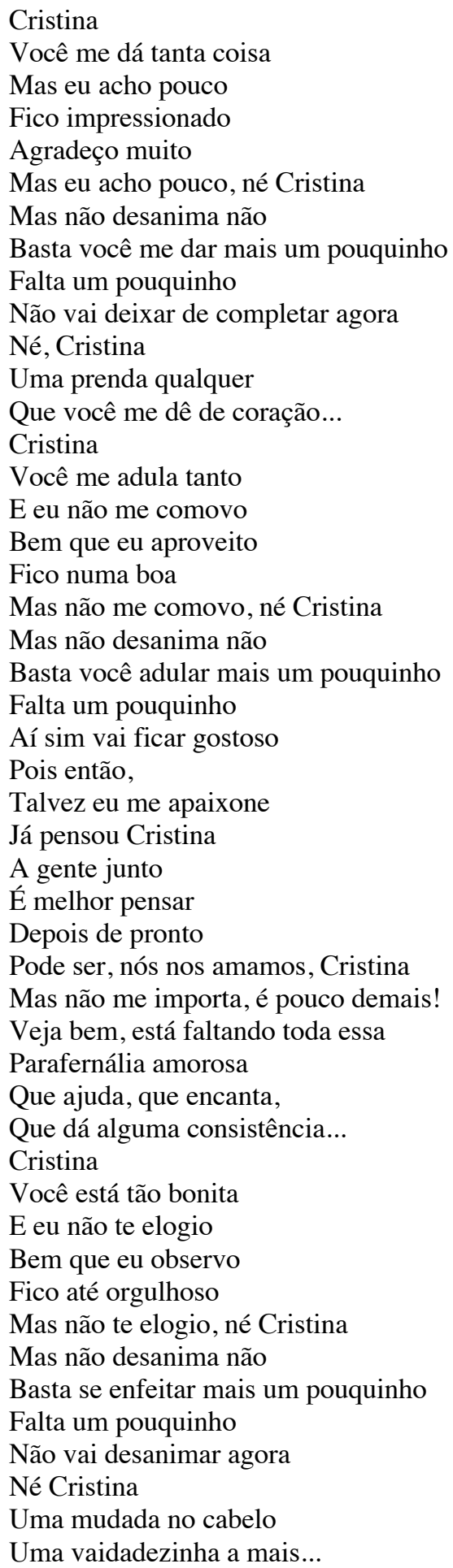

Mas não somente com ironia o amor - tema universal da canção popular - é tratado pelo Grupo Rumo. A canção Verdadeiro Amor tem o mérito de abordar o tema de modo original, o que é algo extraordinário se pensarmos nas infinitas vezes que ele ocorre na canção popular de todos os tempos e todos os países. Novamente, o tom coloquial da entoação, dessa vez na voz da cantora Na Ozzetti, produz uma leve estranheza no ouvinte, 
estranheza que condiz com o desconforto, o "nó na garganta" do eu lírico provocado pela alusão (séria ou irônica) do sentimento:

\author{
Verdadeiro Amor \\ Cê mexe nuns momentos meus \\ Que já estavam tão longe \\ E traz tudo de volta \\ E agora o que é que eu faço com \\ Isso tudo aqui? \\ Tem sido tão desconcertante \\ Que eu fiquei sensível \\ E agora você fala comigo brincando \\ Mas não dá risada \\ Já penso que é sério \\ Me envolvo com a história \\ E sofro meu bem \\ Tanto que quando depois \\ Você ri não adianta \\ Me aperta um nó na garganta \\ Cê tem esse modo de ser \\ Ai meu deus, tão sereno \\ E eu tenho pressa, estou sempre na frente \\ E você não acelera o passo \\ No entanto é irresistível ver você já machucado \\ Insistindo pra que eu veja \\ Onde se situa o verdadeiro amor
}

O tom coloquial da fala e a abordagem prosaica do tema apresenta-se também na canção Ladeira da Memória, de Zecarlos Ribeiro, na qual os habitantes da cidade são vistos como uma massa, que vaga pela cidade, num movimento como que sem sentido, interrompido só por um momento pela chuva passageira:

\author{
Ladeira da memória \\ Olha as pessoas descendo, descendo, descendo \\ Descendo a Ladeira da Memória \\ Até o Vale do Anhangabaú \\ Quanta gente! \\ Vagando pelas ruas sem profissão \\ Namorando as vitrines da cidade \\ Namorando, andando, andando, namorando \\ O céu ficou cinza e de repente trovejou \\ E a chuva vem caindo, caindo, caindo \\ Prendendo as pessoas nas portas, nos bares \\ $\mathrm{Na}$ beirada das calçadas \\ Quanta gente! \\ Com ar aborrecido olhando pro chão \\ Pro reflexo dos edifícios e dos carros \\ Nas poças d'água \\ E pros pingos, pingando, pingando, pingando \\ Olha as pessoas felizes, felizes, felizes \\ Felizes por que a chuva que caía agora pouco \\ Essa chuva que caia agora pouco já passou
}


Na canção acima, as pessoas são observadas num vaguear, o qual se apresenta sem um objetivo concreto. Mesmo assim as pessoas se aborrecem quando o fluxo da cidade é interrompido e se alegram quando podem retomá-lo. A canção Pro bem da cidade também retrata o fluxo da cidade, aqui incorporado pelo ônibus, que não espera, a não ser que o eu lírico se apresse, e pela São Paulo que não pode esperar. Há conflito entre o ritmo da cidade e o ritmo do eu lírico que, novamente usa uma impostação de voz meiga e ingênua. Ele decide então quixotescamente mudar a cidade, já que ele não mudará:

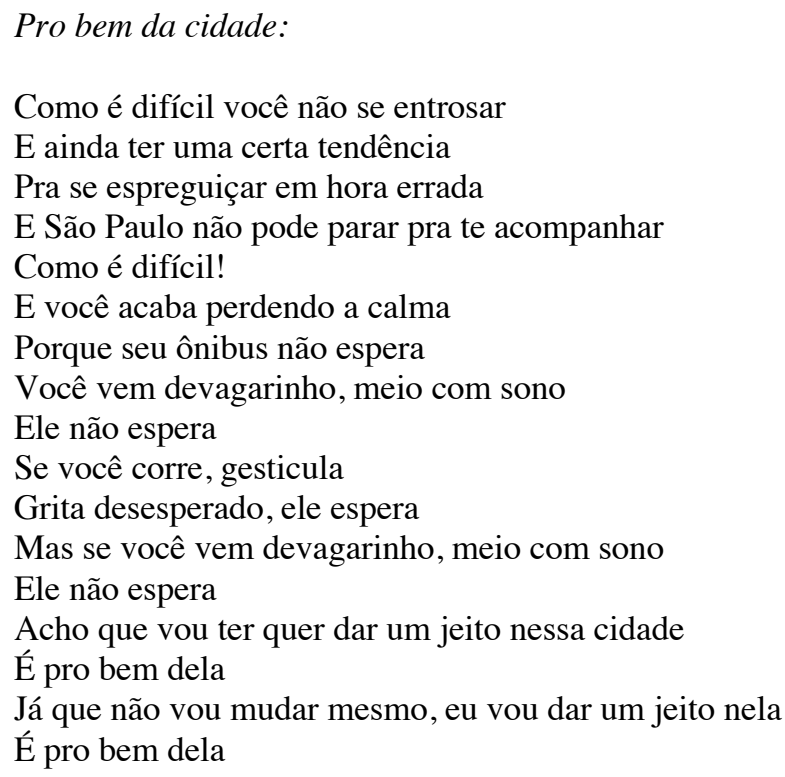

O Grupo Rumo também possui canções que aludem à opressão do regime militar e à perspectiva de redemocratização, embora sempre de modo insuspeito. É o caso da canção Bem baixinho, na qual se pensa que o narrador fala a respeito de uma mulher "meio velha, mas é tão bonita!". Mulher que, na verdade, é a nação que sussurra bem baixinho ao ouvido "estou livre outra vez!":

\section{Bem baixinho}

Gosto dela meio velha assim mesmo

Ainda ontem eu comentei com meu amigo

Ela é meio velha mas é tão bonita!

E ele disse: puxa! é mesmo!

Ela é assim meio velha mas é tão bonita!

E é uma beleza espontânea e natural

Não tem medo de dizer

Que está amando outra vez

E não diz de qualquer jeito, não

Num momento que você está atento 
Ela cochicha baixinho e tão pertinho

Que só pode ser você dessa vez

E essa nação é assim com todo mundo

Grandalhona, meio velha, mas uma musa e tanto

E quando você menos espera ela diz:

Estou livre outra vez!

Outra alusão insuspeita ao regime militar é feita na canção $A h$ ! O tom alegre da canção que repete várias vezes a interjeição $A h$, além de outras, parece estar aludindo ao processo de composição, à escolha das palavras e ao encaixe de sonoridades. Não fosse o depoimento de Paulo Lepetit no documentário Lira Paulistana e a Vanguarda Paulista, dificilmente se adivinharia que a canção fala sobre a censura. A expressão $a h$ denota a exclamação do eu lírico ao ver suas palavras sendo cortadas pelo censor, o qual ele tenta sem sucesso convencer a respeito da qualidade da palavra:

$A h !$ (Luiz Tatit)

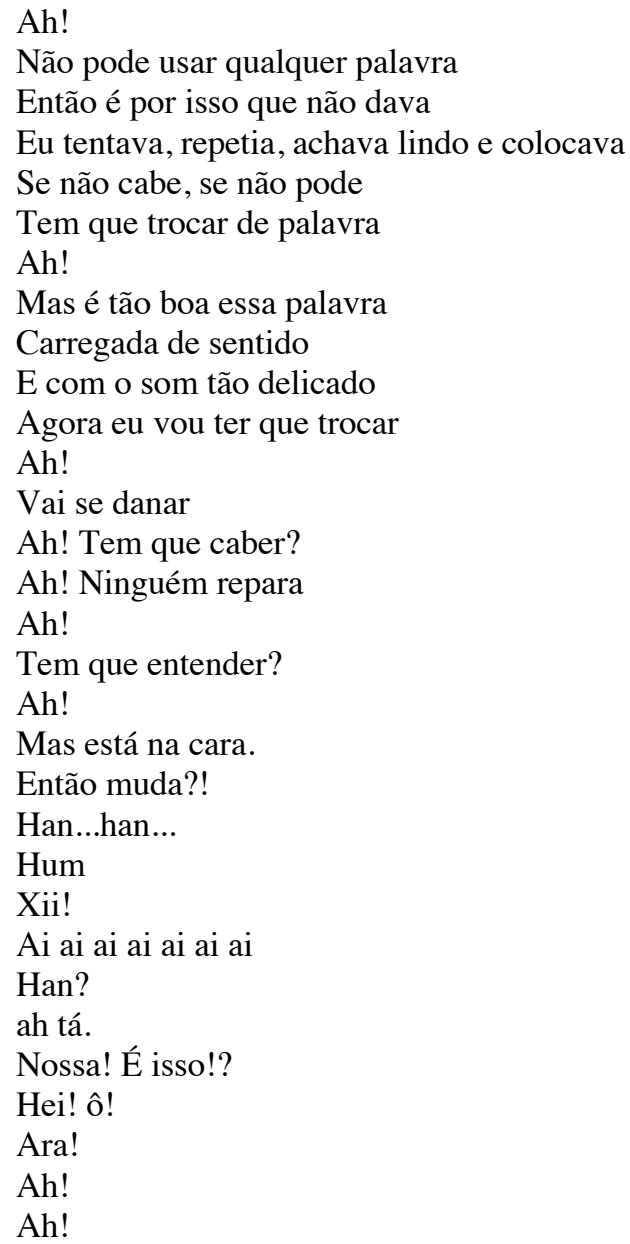


A canção que de fato alude ao processo de composição, à união de melodia e letra e também ao circuito independente de produção musical é a Canção Bonita.

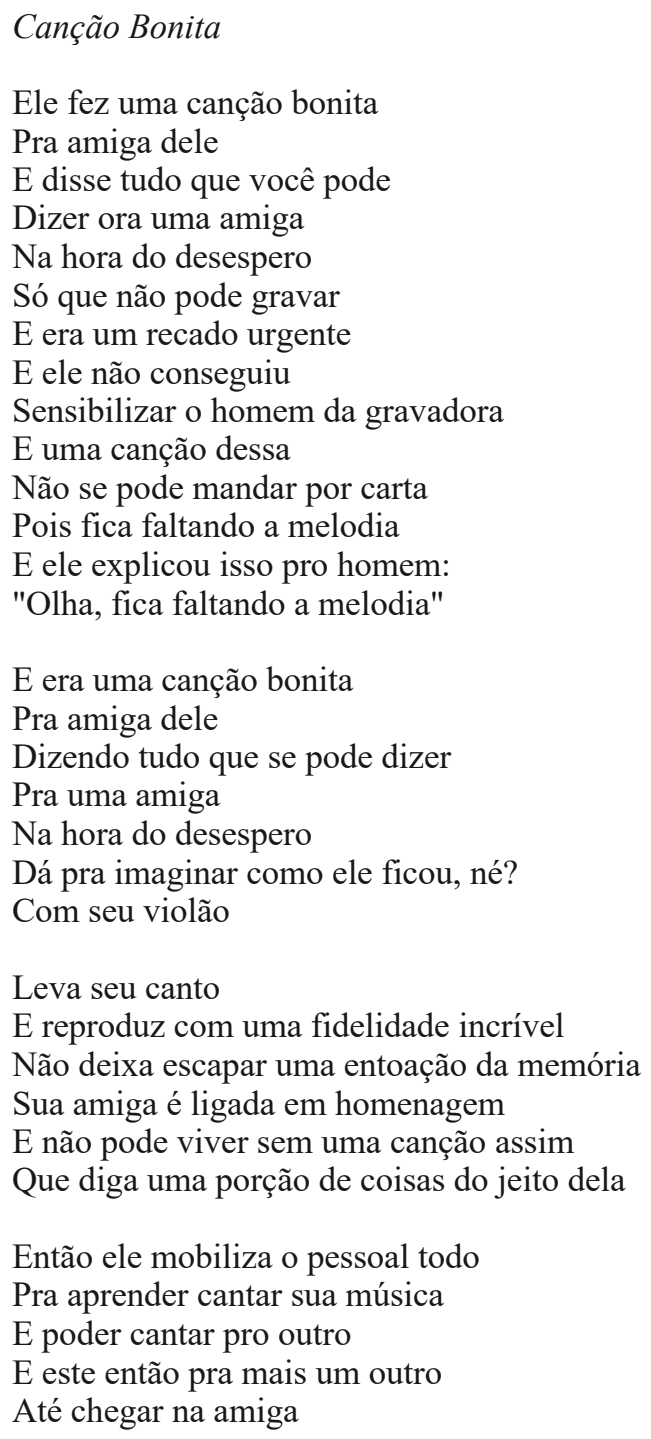

As canções do Rumo utilizam, quase todas, um tom coloquial de impostação de voz, muito próximo à fala cotidiana. Esse recurso foi conceituado por Tatit como figurativização: o recurso de produção da fala no canto, em que a linha melódica da canção reproduz as inflexões da fala cotidiana. Segundo Tatit (2012, p. 21), trata-se de uma tendência presente em toda canção popular, que possui dois importantes efeitos estéticos: ela dá ao ouvinte a impressão de verdade do que está sendo dito na canção, e dá também ao ouvinte o efeito de naturalidade no como está sendo dito. Esses efeitos estéticos realçam, nas canções do Rumo, os retratos prosaicos, ingênuos, mas (por isso mesmo) críticos da cidade, da política e das relações. $^{39}$

${ }^{39}$ Os conceitos semióticos de Tatit serão discutidos com mais profundidade no próximo capítulo. 


\subsection{Itamar Assumpção}

Itamar Assumpção ${ }^{40}$ nasceu na cidade de Tietê, São Paulo, em 1949, e em 1962 mudou-se com a família para o Paraná (GARCIA, 2015). Seu pai era pai-de-santo, e a experiência com os ritmos e a religiosidade afro foi decisiva pata Itamar: "a música encantatória, com ritmo forte marcado pelas batidas e capaz de fazer o corpo despertar para o transe, [era] a sua base musical, e sobre essa base ele [iria] construir uma obra inteira" (GARCIA, 2015). Itamar foi autodidata em violão e piano, ator em grupos universitários de teatro e também participou de festivais de música. Embora inserido nos meios estudantis, estamos diante de um perfil distinto dos demais integrantes da Vanguarda Paulista. Diferente dos outros, Itamar era negro e carregou em sua trajetória e na sua música a herança da cultura africana.

Não foi estudante da USP, tampouco cursou música. Seu percurso teve dificuldades que os outros independentes não tiveram. Em Londrina (onde conheceu Arrigo Barnabé), ele foi preso por estar portando um gravador que lhe havia sido emprestado por um amigo. A polícia não acreditou no empréstimo e Itamar ficou preso por alguns dias. Ao se mudar para São Paulo, ele trabalhou como entregador de carnês de IPTU, e assim girou pela cidade inteira, como diz em sua música Embalos. Nessa época, costumava andar com recortes de jornal para provar que era artista, caso fosse abordado pela polícia. Esses fatos da sua biografia certamente marcaram a sua produção musical:

O personagem Beleléu - que ressurgiu nos discos seguintes e inspirou boa parte das letras de suas canções - foi uma ideia de Itamar, fruto da sua experiência cotidiana na cidade de São Paulo. Itamar Assumpção havia sido preso duas vezes por ter sido considerado suspeito pela polícia. Negro, morador da Zona Leste de São Paulo, numa região periférica da cidade, o compositor andava com recortes de jornais que serviam como documentos para que pudesse comprovar que era artista. Esta experiência lhe deu, além da inspiração para a criação das músicas, a ideia da concepção teatral para o espetáculo de estréia do seu primeiro LP, lançado no final do ano de 1980. (OLIVEIRA, 2002, p. 72)

Itamar rapidamente envolveu-se com o Lira Paulistana, e podemos argumentar que o teatro se transformou em gravadora graças a ele, que foi um dos premiados no Festival de

40 Discografia de Itamar Assumpção: Beleléu, Leléu, Eu (1980), Às Próprias Custas S/A(1981), Sampa Midnight - Isso não vai ficar assim (1983), Intercontinental! Quem diria! Era só o que faltava!!! (1988), Bicho de Sete Cabeças Vol I, II, III,(1993), Pretobrás (1998). 
Música da Feira de Artes da Vila Madalena, de 1980. Wilson Souto Jr. foi um dos jurados e convidou-o a apresentar-se no Lira com regularidade. Com o sucesso de público das apresentações, e entusiasmados com a qualidade do trabalho, os sócios do teatro decidiram produzir o disco de Itamar, como relatou Wilson Souto Jr. a Daniela Ribas Ghezzi:

\footnotetext{
Nessa época, a gente entrou em contato, eu, o Plínio e o Chico, com o trabalho do Itamar Assumpção, e a gente não resistiu à vontade de fazer um disco com o trabalho do Itamar. E as coisas todas aconteceram assim, não era 'Ah, vamos fazer uma gravadora porque falta uma gravadora. Fizemos uma pesquisa de mercado e ...' Não. O Itamar se apresentou no Lira uma ou duas vezes, e era uma coisa que nós ficamos completamente apaixonados pelo trabalho dele. Aí eu assisti, e falei "Vocês precisam assistir", e eles foram ver, e a gente ficou completamente encantado. Então, nós fizemos uma vaquinha entre os três, e fomos pagando o disco de Itamar. O Plínio era uma pessoa que era um bom assalariado, porque ele era engenheiro da Microservice (...). E a gente conseguiu, sem dúvida, rapidamente, recuperar esse investimento, e gostamos da atividade. Aí, o Itamar incentivou a gente a fazer o segundo disco, que foi do Tiago Araripe e, a partir dali todo mundo nos usava como equipe de produção de discos (SOUTO Jr. Apud GHEZZI, 2003, p. 140).
}

Envolvido no circuito universitário e independente, mas com um percurso distinto dos demais, o trabalho de Itamar apresenta características peculiares. Sua música destaca-se pelo trabalho na dimensão rítmica. As linhas melódicas de suas canções são frequentemente "quebradas" por intensidades rítmicas diversas, enquanto os instrumentos geralmente acompanham o ritmo entoado pela voz. Diferentemente da entoação praticada pelo Rumo, que recupera a fala cotidiana, Itamar realiza o contrário - é a fala que mimetiza instrumentos de percussão e ritmos da música negra, como o Reggae e o samba. Segundo Regina Machado $^{41}$, nas suas canções, há intervenções de vozes que por vezes quebram a regularidade da harmonia e da linha melódica. As muitas linhas melódicas e vocais utilizadas em consonância com os significados do texto, faz com que o universo sonoro passe a ser mais um fator de comunicação.

As canções de Itamar tematizam com frequência o cotidiano da cidade de São Paulo, mas de uma perspectiva bem mais agressiva do que aquela apresentada pelo Rumo, ou pelos grupos Língua de Trapo e Premeditando o Breque. O seu personagem Beleléu apresenta-se

\footnotetext{
${ }^{41}$ Regina Machado. A voz na canção popular brasileira: um estudo sobre a Vanguarda Paulista. 2007.
} Dissertação de Mestrado - Universidade Estadual de Campinas. Instituto de Artes. 
como o "Vulgo nego Dito cascavé", (na música Nego Dito) que "Se chama a polícia/ A boca espuma de ódio". Portanto, a música de Itamar faz uso de recursos estéticos refinados, assim como Arrigo Barnabé ou o Grupo Rumo, mas também faz uso de elementos da herança afro e constrói um personagem distinto do perfil universitário dos demais artistas da Vanguarda Paulista.

\title{
Canções de Itamar Assumpção:
}

Os dois primeiros discos de Itamar Assumpção, assim como Clara Crocodilo de Arrigo Barnabé, narram a história de um marginal, histórias nas quais as características desses personagens incorporam aspectos da produção musical (marginalizada) de seus autores. Segundo Luiz Tatit (2014), há similitude entre a negritude, a marginalidade e os desatinos de Benedito João dos Santos Silva Beleléu e as idiossincrasias do compositor. Nos primeiros discos de Itamar, há retratos de "situações de fala nas quais o personagem se definia" (TATIT, 2014, p.314), retratos de uma identidade musical onde compositor e eu lírico se confundem:

\section{Nego dito}

\author{
Meu nome é \\ Benedito João dos Santos Silva Beleléu \\ Vulgo Nego Dito, Nego Dito cascavé \\ Eu me invoco eu brigo \\ Eu faço e aconteço \\ Eu boto pra correr \\ Eu mato a cobra e mostro o pau \\ Pra provar pra quem quiser ver e comprovar \\ Me chamo Benedito João dos Santos Silva Beleléu \\ Vulgo Nego Dito, Nego Dito cascavé \\ Tenho o sangue quente \\ Não uso pente meu cabelo é ruim \\ Fui nascido em Tietê \\ Pra provar pra quem quiser ver e comprovar \\ Me chamo Benedito João dos Santos Silva Beleléu \\ Vulgo Nego Dito, Nego Dito cascavé \\ Não gosto de gente \\ Nem transo parente \\ Eu fui parido assim \\ Apaguei um no Paraná, pá, pá, pá, pá \\ Meu nome é Benedito João dos Santos Silva Beleléu \\ Vulgo Nego Dito, Nego Dito cascavé \\ Quando tô de lua \\ Me mando pra rua pra poder arrumar \\ Destranco a porta a pontapé \\ Pra provar pra quem quiser ver e comprovar \\ Me chamo Benedito João dos Santos Silva Beleléu
}


Vulgo Nego Dito, Nego Dito cascavé

\author{
Se tô tiririca \\ Tomo umas e outras pra baratinar \\ Arranco o rabo do satã \\ Pra provar pra quem quiser ver e comprovar \\ Me chamo Benedito João dos Santos Silva Beleléu \\ Vulgo Nego Dito, Nego Dito cascavé
}

Se chamá polícia

Eu viro uma onça

Eu quero matar

A boca espuma de ódio

Pra provar pra quem quiser ver e comprovar

Me chamo Benedito João dos Santos Silva Beleléu

Vulgo Nego Dito, Nego Dito cascavé

Se chamá polícia

Eu vou cortar tua cara

Vou retalhá-la com navalha

A essa primeira fase, onde criador e obra se confundem, seguiu-se, ainda segundo Luiz Tatit, que o personagem marginal de Itamar Assumpção se foi impregnando cada vez mais nas instabilidades entoativas do canto, de modo que a personalidade do compositor se acomodou no interior das canções, na forma de recursos técnicos característicos. O mais conhecido talvez seja o "rock de breque", expressão inventada para designar as frases interrompidas e os diversos acontecimentos musicais simultâneos nas canções de Itamar. Outra marca do compositor são as canções em que poucos acordes e frases musicais que se em ostinato (que se repetem insistentemente ao longo da peça) dão a estabilidade mínima para que o canto se desdobre livremente pelas rimas e temáticas mais inusitadas, por vezes em livre associação sonora entre as palavras. A ênfase passa então do conteúdo à forma de dizer, como se pode ver na canção "Venha até São Paulo", na qual nomes de bairros e características da cidade se vão associando por similitude sonora:

\title{
Venha até São Paulo
}

Venha até São Paulo

São Paulo tem socorro, tem liberdade, tem bom retiro

Tem esperança, tem gente e mais gente, cabe invade

São Paulo tem muitos santos espalhados pelo estado

Tem são Judas, São Caetano, Santo André, tem São Bernardo

Tem são Miguel, São Vicente, do outro lado tem São Carlos

Tem santo

Que nem me lembro são João Clímaco, Santo Amaro e a capital São Paulo

Tem o largo de São Bento no centro

E no litoral tem Santos, há santas também

É claro, Santa Ifigênia, Santana, Santa Cecília,

Tem Santa Clara...

Venha até São Paulo ver o que é bom pra tosse

Venha até São Paulo dance e pule o rock and rush

Entre no meu carro vamos ao largo do arouche 


\author{
Liberdade é bairro mas como Japão fosse \\ Venha nesse embalo concrete fax telex \\ Igreja praça da sé faça logo sua prece \\ Quem vem pra São Paulo meu bem jamais esquece \\ Não tem intervalo tudo depressa acontece \\ Não tem intervalo \\ Vai e vem e tchan e tchum êta sobe desce \\ Gente do nordeste, do norte aqui no sudeste \\ Batalhando nesse mundaréu de mundo que só cresce \\ Só carece \\ Venha até São Paulo relaxar ficar relax \\ Tire um xérox, admire um triplex \\ Venha até São Paulo viver à beira do stress \\ Fuligem catarro assaltos no dia dez
}

\title{
2.5 Língua de Trapo e Premeditando o Breque
}

Os grupos Língua de Trapo e Premeditando o Breque serão tratados em conjunto, porque ambos possuem uma característica fundamental comum: são grupos que se valem do humor como forma de crítica, tanto dos clichês musicais das canções comerciais, quanto da situação política do Brasil na década de 1980.

O Língua de Trapo ${ }^{42}$ foi criado em 1979, por estudantes de Comunicação Social da Faculdade Casper Líbero - Laerte Sarrumor, Guca Doenico, Luiz Domingues, Carlos Castelo, Lizoel Costa, Pituca, Carlos Melo e João Lucas -, entre outros que se juntaram ao longo do percurso do grupo. Do ponto de vista formal, suas canções copiam as canções de sucesso das rádios de sua época, como a jovem guarda, as baladas românticas, boleros, etc. No entanto, em cima desses "produtos pré-fabricados", as letras de teor humorístico faziam sátiras nada indiretas ao ridículo das canções de sucesso e da situação política: "resolvemos montar um grupo musical que, pelo humor, com a capacidade de deixar nu o grotesco das coisas, faríamos nossa crítica à realidade brasileira" (Cf. OLIVEIRA, 2002, p. 32).

Desse modo, servindo-se ao mesmo tempo da linguagem musical das canções de grande sucesso nos meios de comunicação de massa, e de letras que contradizem os lugares comuns de tais canções, o Língua de Trapo esforçou-se em fazer paródias que estimulassem o senso crítico de seus ouvintes, contra a mediocridade artística ou política:

\footnotetext{
Ao longo de sua experiência, os rapazes foram diversificando suas opções e passaram a construir uma linguagem própria a partir dos destroços sonoros deixados pelo vendaval do rock, iê-iê-iê, bolero, samba canção, tango e outros gêneros menos votados. É assim que a sátira, (diretamente política inclusive)
}

\footnotetext{
42 Discografia do Língua de Trapo: Língua de Trapo (1982), Como é Bom Ser Punk (1985), 17 Big Golden Hits Super Quentes Mais Vendidos No Momento (1986), Sutil como um Cassetete (1980), Sem Indiretas (1984).
} 
montada pelo Língua de Trapo ao longo dos seus shows Sutil como um Cassetete, Obscenas Brasileiras e, o último, Sem indiretas, envolvem conhecidos personagens como Paulo Maluf [...], Roberto Carlos (Burrice precoce), Fernando Gabeira (O que é isso companheiro?), Cauby Peixoto (Tragédia Gramatical), o machismo (Tango do Bidê), o feminismo (Insurreição feminina, com citação direta de Lindomar Castilho), a política do "Brasil Grande"/integração econômica (Xingu Disco) e hábitos da classe média (Concheta). (ARTE em Revista, 1984 p. 20)

Aqueles que ouvem hoje as canções do Língua de Trapo, podem surpreender-se com os pueris trocadilhos escatológicos dos quais eles se servem largamente, mas há que se levar em conta o contexto histórico e político. A ditadura alinhava imoralidade e comunismo, por um lado, e moralidade e família, por outro. Apenas com a abertura, a partir do governo de João Batista Figueiredo (1980), último presidente da ditadura militar, "imoralidades", como o nu, passaram a ser toleradas em publicações para maiores de 18 anos. ${ }^{43}$ Portanto, mesmo os trocadilhos do Língua de Trapo ganham conotação política, quando postos em contexto.

O Premeditando o Breque ${ }^{44}$ foi criado em 1976, por alunos da ECA que, assim como os integrantes do grupo Rumo, se ressentiam da falta de espaço para a música popular, no Departamento de Música. Seus integrantes eram: Wandi Doratiotto, Mário Manga, Claus Petersen e Marcelo Galbetti. O grupo, cujas canções também se caracterizam pelo humor, sátira e ironia, realiza trabalho original e de alta qualidade na parte instrumental, apelando para o inusitado também na forma das canções. Nos arranjos, o grupo mescla vários estilos de música popular e também referências eruditas. Em 1979, a canção Brigando na Lua ficou em segundo lugar no Primeiro Festival Universitário de Música Popular, tendo perdido apenas para Diversões Eletrônicas, de Arrigo Barnabé. Essa canção “é um verdadeiro 'compêndio' de informações, em diferentes registros”' (FENERICK, 2007, p. 125). De fato, a canção transita de uma peça atonal, de Webern, ao samba de breque. Essa fusão de estilos pela via da ironia e do inusitado viria a ser uma das características centrais do grupo que, em suas letras, fazia crônicas bem-humoradas dos costumes e do cotidiano paulistano:

No primeiro LP, a crônica da vida paulistana começa com a feijoada do Sábado, passa pela viagem de fuscão à Praia Grande e pela Kombi viciada no caminho para

\footnotetext{
${ }^{43}$ A este respeito, veja-se, de Juliana BATISTA, O universo de Clara Crocodilo: História e música no LP de Arrigo Barnabé, 2013, op. cit.

44 Discografia do Premeditando o Breque: Premeditando o Breque/Empada Molotov Fervura [1980], Premeditando o Breque (1981), Quase Lindo (1983), O melhor dos iguais (1985), Grande Coisa (1986), Alegria dos homens (1991).
} 


\begin{abstract}
o CEASA, acabando num trágico mergulho de avião, depois do brilhante bregabestialógico (Nunca). São marchinhas, rocks e outras linguagens/sons mais contemporâneos. No segundo LP ampliam-se os horizontes: o Premê faz uma delirante sátira de New York, New York, aproveitando a oportunidade para ironizar as pretensões cosmopolitóides da classe média paulistana. (Arte em revista, p. 20)
\end{abstract}

Tanto o Língua de Trapo quanto o Premeditando o Breque foram grupos que satirizaram os clichês das canções que circulavam pelos meios de comunicação de massas, valendo-se da ironia como forma de crítica.

\title{
Canções do Língua de Trapo
}

Apresentamos abaixo duas canções do Língua de Trapo que satirizam o público que frequentava a Vila Madalena, no início da década de 1980. Na Ouriço da Vila, podemos observar a enxurrada de citações e de referências que pertencem ao mundo acadêmico, mas aqui usadas sem nenhum rigor num ambiente de sociabilidade, o bar. Mesmo o ouvinte de hoje pode reconhecer nessa canção as típicas rodas de cerveja dos estudantes da faculdade de fílosofia. Já na Bartolo Bar, temos a mesma cena, o bar, mas agora com uma descrição mais focada no estilo pessoal dos frequentadores.

\section{Ouriço da Vila}

Eu fui à Vila Madalena apanhar minha pequena

Prum programa legal, pegar uma tela e o escambau

E na Fradique Coutinho entrei lá no Sujinho

Pra me ambientar, a inteligenzia toda lá

E quando fui entrando, fui logo morando

Um papo diferente, na mesa de um livre docente

Ele defendia uma tese esdrúxula, paradoxal:

- Levando-se em conta o alcoolismo crônico de Scoth Fitzgerald

E a homossexualidade imanente de Proust

Temos, pois, que E é igual a $\mathrm{MC}$ ao quadrado, morô?

Me encostei no balcão e feito um espião observei o alarde

Só dava Freud e Thomas Hardy

Eu fui me irritando, e o papo piorando

Pura citação, de Baudelaire até Platão

E tome Kurosawa, e tome James Joyce

E tome Hemingway, é tanto nome que nem sei

Saí meio grogue, chamando Van Gogh de Galileu Galilei

Jorge Goulart de Nora Nei

Eu sou um erudito de alto gabarito intelectual

Leio Camões no original

Sou pós graduado, formei-me advogado pelo telefone

Via Embratel pela Sorbonne

Assino o Estadão, sou da oposição

Abaixo o sistema, já critiquei até cinema 
Eu vou em gafieira, me amarro no Gabeira

E tô desempregado

Um dia eu chego a Jorge Amado

Voltei àquela bodega com uma raiva cega

E cuspindo prego

Me alteraram o super-ego

E fui logo citando, no estilo Marlon Brando

Uma frase em latim:

- Homus obispus James Dean

Os caras se borraram e já me contrataram para lecionar

Como professor titular

$\mathrm{Na}$ universidade da nossa cidade

$\mathrm{O}$ idioma latino

Data vênia, Hare Krsna, como anda bem o nosso ensino!

\section{Bartolo Bar}

Bartolo Bar à média-luz, una porraloca me seduz

Hasta me enfeitiçar

Bartolo Bar de mi amor, una empanada de couve-flor

E una cerveza pra entornar

Stalin, Trotsky y Mao

Son tratados por igual, sin ninguna distinción

Porque o que vale en Fradique

É ser mismo beatnik, abajo la revolución

Yo creo mismo que no hay un ser humano

Igual ao fulano que habita la Vila

Porque en la noche, elle, que és un farrista

En la mañana seguinte se tuerna un naturalista

Por esto mismo és tan difícil defini-lo

Elle que seguramiente, tiene un estraño estilo

Pero se vires alguién de sandália Havaiana

A fumar marijuana

Estás delante de un bicho-grilo!

\section{Canções do Premeditando o Breque}

Assim como o Língua de Trapo, o grupo premeditando o Breque trabalhava com o humor em suas canções. Abaixo, segue uma canção do primeiro álbum do grupo, que satiriza a condição do músico independente e a sua dependência financeira:

\section{Conflito de gerações}

Se és essa figura incrível que aos gritos tu proclamas Se tens o dom dos grandes vultos e talento tu derramas Me explica este teu desemprego e esse vagar ao léo

Pois moras com este velho pai, não pagas aluguel

Se és esta figura imensa que habita este planeta Se tens o dom dos grandes vultos e és "jóia da veneta" Me explica este teu desemprego e esse vagar ao léo Pois moras com este velho pai, não pagas aluguel

Veja o teu irmão mais moço

Sinta o quanto ele subiu 
Nem parece a mesma mãe que o pariu

Tens a mania arrogante de fazeres verso

E a petulância maior de tocares violão

Sai desse vida, filho querido

Vem que te dou proteção

És tão novinho, só tens 30 anos

Busca teu futuro em minhas mãos

O Premeditando o Breque se notabilizou, principalmente, pelas sátiras que fez da cidade de São Paulo. A cidade é aqui retratada, novamente, em um viés nada vantajoso. $\mathrm{O}$ clima alegre e humorístico das canções faz ressaltar ainda mais o absurdo das cenas retratadas: na primeira, um lava rápido de gente inaugurado no centro da cidade para aliviar a rotina do povo sem tempo, na segunda, uma paródia de New York New York, vemos uma cidade que em tudo contrasta com as pretensões de metrópole.

\section{Lava rápido}

Foi pensando nesse povo

Que trabalha o dia todo

E chega a noite

Sai correndo e vai estudar

Não tem tempo de jantar

Não dá pra tomar banho

E nessas bandas geralmente faz calor

Foi que eu resolvi montar

Com qualidade

Um lava rápido de gente

Lá no centro da cidade

E funcionou, funcionou, funcionou

E funcionou mais do que você imagina

E quando vem a tarde

$\mathrm{O}$ povo se aglutina

Por volta das dezoito

Forma fila até a esquina

E lava um japonês

E lava um siciliano

E vem uma libanesa

E agora tem pernambucano

A máquina é moderna, sistema americano

De um lado tem escovas

Do outro um grande pano

Enquanto um lado esfrega

O outro vai enxugando

E funcionou...

E o bom desse sistema

É o clima que ele cria

Se o nego chega murcho

Sai pleno de alegria 
Se a moça chega triste

Sai pronta pr'outro dia

São Paulo, São Paulo

É sempre lindo andar na cidade de São Paulo

O clima engana, a vida é grana em São Paulo

A japonesa loura, a nordestina moura de São Paulo

Gatinhas punk, um jeito yankee de São Paulo

$\mathrm{Na}$ grande cidade me realizar

Morando num BNH

$\mathrm{Na}$ periferia a fábrica escurece o dia

Não vá se incomodar com a fauna urbana de São Paulo, de São Paulo

Pardais, baratas, ratos na Rota de São Paulo

E pra você criança muita diversão

E pauluição

Tomar um banho no Tietê ou ver tv

$\mathrm{Na}$ grande cidade me realizar

Morando num BNH

Na periferia a fábrica escurece o dia

Chora Menino, Freguesia do Ó, Carandiru, Mandaqui, aqui

Vila Sônia, Vila Ema, Vila Alpina, Vila Carrão, Morumbi

Pari

Butantã, Utinga, é M'Boi Mirim, Brás! Brás! Belém

Bom Retiro, Barra Funda, Ermelino Matarazzo

Mooca, Penha, Lapa, Sé

Jabaquara, Pirituba, Tucuruvi, Tatuapé!

Pra quebrar a rotina num fim de semana em São Paulo

Lavar um carro comendo um churro é bom pra burro

Um ponto de partida pra subir na vida em São Paulo

Terraço Itália, Jaraguá, Viaduto do Chá

Na grande cidade me realizar morando num $\mathrm{BNH}$

$\mathrm{Na}$ periferia a fábrica escurece o dia

Essa pequena seleção de canções da Vanguarda Paulista mostra-nos que Arrigo Barnabé não estava sozinho ao compor retratos urbanos que, ao mesmo tempo, dialogavam com a história das formas da canção popular e propunham novas formas "revolucionárias". A Vanguarda Paulista procurou produzir o novo, dar o "passo adiante", mas, conscientemente ou não, o tema das canções rondou a cidade de São Paulo. A tematização da cidade foi feita em muitas dessas canções pelo uso do chiste, da ironia, explicitando o que a cidade tem de problemático, violento, desumano. Essa representação esta, por sinédoque, estende-se a um comentário sobre a modernização brasileira (como pretendemos argumentar ao longo desta tese). Contudo, no mesmo ato, tematiza-se também o campo de produção das 
canções e a posição que esses grupos, os independentes, ocuparam, como procuraremos desenvolver adiante.

\section{O teatro Lira Paulistana e o circuito independente}

Muito da Vanguarda Paulista se deve à existência do teatro Lira Paulistana, um espaço catalisador da cultura universitária "alternativa" da época. Localizado no bairro de Pinheiros, próximo à praça Benedito Calixto e das universidades PUC e USP, jovens, em sua maioria estudantes, lá encontraram um espaço de promoção da cultura "independente". A Vanguarda Paulista consistia numa movimentação musical e cultural feita por e para universitários, alimentada pelo ideal de cultura "alternativa" e "independente".

O teatro Lira Paulistana surgiu num momento de crise no mercado fonográfico e de fechamento da indústria para novas propostas. Foi criado por um jovem estudante de engenharia e músico nas horas vagas, chamado Wilson Souto Jr., que alugou um antigo depósito localizado na rua Teodoro Sampaio, número 1091, com a intenção de lá construir um teatro. Situado em frente à praça Benedito Calixto, o teatro Lira Paulistana foi inaugurado no final de 1979. A Wilson Souto Jr., juntaram-se Francisco Pardal (estudante de filosofia na USP), Fernando Alexandre (jornalista na Gazeta de Pinheiros), Plínio Chaves e Ribamar de Castro (artista plástico). O Lira Paulistana não foi pensado como um espaço para a música, mas era tamanha a demanda de um espaço para a exibição de bandas de pouca expressão que, rapidamente, as apresentações musicais tomaram conta de toda a programação do teatro, de segunda a domingo (OLIVEIRA, 2002). Essas bandas, as quais viriam a ser chamadas de "independentes", não formavam um movimento, mas se aglutinaram por conta da dificuldade comum de encontrar um espaço para o seu trabalho. $\mathrm{O}$ Lira Paulistana rapidamente expandiu as suas atividades, tornou-se uma gráfica, uma pequena loja de discos e uma gravadora, que iniciou seus trabalhos lançando o primeiro disco de Itamar Assumpção, Beleléu (1980). Esse espaço passou então a exercer, de forma inesperada, mas muito bem-sucedida e notória - posto que foi amplamente divulgado e saudado pela imprensa (CASTRO, 2014) - a função de mediador cultural do que se passava com os jovens da Vila Madalena, os artistas e o incipiente mercado de música independente. Portanto, um pequeno teatro de 200 lugares, num porão da Teodoro Sampaio, tornou-se o centro dessa movimentação musical chamada Vanguarda Paulista. Em 1984, Fernando Alexandre, um dos sócios do teatro, assim definiu as intenções dos proprietários no momento de abertura do Lira: 


\begin{abstract}
A única coisa que tínhamos clara no dia 25 de outubro de 1979, quando o porão da Teodoro tava quase pronto e inauguraríamos o teatro, era de que seria um espaço para coisas novas. [...] Mas sabíamos muito bem o que pretendíamos ser: um veículo para toda aquela produção cultural emergente, marginalizada pelos espaços institucionais e que vinha sobrevivendo em porões particulares, garagens, e consumidas apenas pelos amigos mais próximos. (Arte em revista, 1984 p. 35)
\end{abstract}

O teatro teve grande importância para a chamada Vanguarda Paulista por ter sido o "ponto de encontro", o espaço onde artistas que estavam desenvolvendo novas linguagem musicais encontraram um público disposto a entrar em contato com essas novidades. Também foi importante por colocar em contato entre si artistas das mais variadas vertentes da música popular. A primeira apresentação musical no Teatro foi um show de música caipira chamado Vozes e Violas (CASTRO, 2014, p.44), do qual participaram Almir Sater e Alzira Espíndola, entre outros. A essa apresentação seguiram-se muitas outras, de grupos instrumentais como a Freelarmônica, Pau-Brasil e Pé Ante Pé, assim como grupos de inspiração humorística como Língua de Trapo e Premeditando o Breque, e até mesmo artistas experimentais como o grupo Rumo e Itamar Assumpção.

Não foram poucos os depoimentos ${ }^{45}$ que realçavam o potencial do teatro, durante a sua curta existência (de 1979 a 1986), para reunir e fomentar o que as pessoas estavam criando. Ná Ozzetti ${ }^{46}$ foi uma das que enfatizaram o teatro como ponto de convergência, lugar onde artista e público confluíam, espaço que proporcionou o aparecimento de uma geração de artistas justamente pela capacidade que teve de reuni-los em um só lugar. Suzana Salles ${ }^{47}$ ressalta que, sem o Lira, provavelmente os percursos dos artistas iriam se esgarçar e essa efervescência cultural conhecida como Vanguarda Paulista se perderia e diluiria.

O Lira Paulistana dispunha de uma estrutura pequena e precária; afinal, tratava-se de um porão na rua Teodoro Sampaio, adaptado para uma arena de shows. Mas justamente a precariedade exercia o seu charme, como disse Luiz Tatit: "Era ali que as coisas aconteciam... Era uma espécie de catacumba, onde se faziam muitas coisas que não aconteciam na superfície" (CASTRO, 2014, p.19). Ainda segundo Tatit, apenas aqueles que desciam às catacumbas poderiam ver o que estava acontecendo de novo na música paulistana.

\footnotetext{
45 Depoimentos registrados no documentário: Lira Paulistana e a Vanguarda Paulista. Riba de Castro, 2010.

46 Ná Ozzetti é cantora, nascida em São Paulo e fez parte do grupo Rumo.

47 Cantora, trabalhou com Arrigo Barnabé e Itamar Assumpção.
} 
Essa estrutura precária do teatro não era, contudo, um problema. O espaço, justamente por ser pequeno, era convidativo para músicos que estavam começando. As arquibancadas, justamente por contarem com poucos lugares, eram facilmente lotadas pelo público estudantil que se interessava por essa produção musical paulistana. Ademais, o público era seduzido pela aura de resistência e contracultura que o teatro possuía, passando a ter cumplicidade com o lugar:

O lugar era barato, o que representava um risco muito pequeno para os artistas. Muitos ali nunca tinham tido a chance de se apresentar com sonoplastia e iluminador. Mesmo os que já tinham uma carreira em andamento não causavam problemas para nós, que trabalhávamos com poucos recursos técnicos. Lembro-me bem, para exemplificar, de um show da Olívia Byington. O teatro lotado, todos os ingressos vendidos e o equipamento de som, 10 minutos antes do horário marcado para a entrada da cantora no palco, pifou... estragou... sei lá o que aconteceu. Nós do teatro, muito constrangidos, tivemos que avisar o público que não haveria show. Para nossa surpresa, foi uma gargalhada só... Para aumentar ainda mais o nosso espanto, no dia seguinte o teatro estava novamente lotado. Ficou muito claro que o desconforto e as limitações técnicas eram um charme daquele período e da nossa casa. (OLIVEIRA, 2002, p. 21)

Mesmo com o encerramento do teatro, ele persiste até hoje como referência de produção musical e como experiência mais geral de um centro e produtor de cultura "independente" e "alternativa", como se pode constatar pelo interesse acadêmico e artístico que o teatro e a Vanguarda Paulista ainda exercem. É recorrente, nos trabalhos sobre a Vanguarda Paulista, a alusão a termos como "contracultura", "produção independente", "alternativa" e também "artistas marginais". Isso se dá por conta do contexto em que esses eventos ocorreram, o período de distensão e abertura da ditadura militar, mas em que ainda persistiam vários entraves à produção cultural: o sonho agora, além da liberdade de expressão, era a liberdade de produção, escapar da "ditadura do mercado":

Alguma forma de marginalidade, requerida ou forçada, está efetivamente na base de significativa produção cultural no período que vem de meados dos anos 70 e constitui um ciclo que não parece ter-se esgotado, mas que desde o início dos anos 80 vem se inserindo no "circuito cultural". De qualquer maneira, trata-se de uma produção que, ao menos ao nível das pretensões e durante algum tempo, apresentouse fora dos padrões menos ou mais estabelecidos do mercado ou da indústria cultural, procurando ensaiar novas alternativas. (Arte em Revista, 1984) 
Gostaríamos de sublinhar que, apesar das declarações dos sócios de que eles queriam fomentar o novo, a produção cultural emergente, essa abertura ao novo não consistia (apenas) em uma postura ideológica. Foi uma possibilidade concreta, aberta pela estrutura diminuta e de baixo custo do teatro. Isso, somado a outros fatores, lhe possibilitou ser um espaço de apoio a artistas cujas obras ainda não tinham praticamente nenhuma circulação. Podemos então dizer que espaços como o Lira Paulistana, ao proporcionar o espaço físico que agregou o percurso de diversos artistas, foram importantes para a produção musical da Vanguarda Paulista. Em um momento de crise no mercado fonográfico, o porão da rua Teodoro Sampaio era um lugar convidativo para artistas no início da carreira e para o público, também universitário, que circulava pelos bairros de Pinheiros e Vila Madalena. A falta de oportunidades para esses artistas ingressarem no circuito das grandes gravadoras obrigou-os a optarem pelo circuito "independente", ou "alternativo". Se, por um lado, isso trouxe dificuldades econômicas para a realização desses trabalhos, por outro, ofereceu uma liberdade de criação para esses artistas que dificilmente seria possível fora do circuito independente, o que acabou por se tornar a qualidade distintiva dessa produção musical.

\section{Independentes}

Quando a produção musical da Vanguarda Paulista começou a ganhar certa notoriedade, prontamente recebeu o rótulo de "vanguarda", assim como os de "independente" e "alternativa". Mas, se se quiser pensar no significado que o termo "independente" adquiriu nesse contexto, seria pouco vantajoso partir das características estéticas desses grupos. O termo "independente" refere-se aqui, antes de tudo, a um determinado tipo de relação que se estabelece na esfera de produção. $\mathrm{O}$ artista independente, nesse contexto, é aquele que assume arcar com os custos de produção do seu disco e também assume a responsabilidade (econômica e por vezes técnica) pela execução das funções técnicas, tal como a gravação, a arte gráfica, a mixagem, etc. Como Itamar Assumpção estampou no título do seu segundo álbum, artista independente é aquele que produz "às próprias custas". "Independente", portanto, referia-se, no caso em questão, aos artistas que não possuíam contrato com as grandes gravadoras e, por conta disso, se viam obrigados a arcar com os custos e procedimentos técnicos que normalmente ficariam a cargo da gravadora. Luiz Tatit assim define a situação do artista independente: 
parte dos empresários-produtores, o artista percorre toda a trajetória da produção e da divulgação do disco, enfrentando toda sorte de obstáculos, pagando todos os custos, para no final concluir que o preço de seu LP não saiu tão caro assim [...], a técnica empregada não foi tão complexa e a distribuição e divulgação em escala modesta foram suficientes para o reembolso do capital inicial. Esses dados não são insignificantes se verificamos que com isso o artista pode dar vazão e continuidade ao seu trabalho, independentemente do julgamento das empresas. (TATIT, 1983, p. 33)

Pode-se compreender melhor essa questão, retomando o argumento de Luiz Tatit, no artigo "Antecedentes dos independentes", que reconstrói a relação entre técnica e arte na canção popular, desde os sambas da década de 1920 até os independentes de 1980, publicado em dezembro de 1983, no dossiê da Arte em Revista dedicado à Vanguarda Paulista. O ponto central do argumento de Tatit é que a linguagem da canção popular, desde o início das gravações, resultou do ajuste entre as funções técnica e artística. Toda vez que ambas se distanciam, por uma autonomia dessincronizada, ocorre o fenômeno de estereotipia. Sem conhecimento direto das possibilidades técnicas e da eficiência de comunicação ao seu alcance, os técnicos das gravadoras acabam engendrando um produto pouco econômico, do ponto de vista da informação. Passam a repetir soluções que outrora deram certo. A racionalização da produção e o esforço de obter um cálculo exato entre investimento e retorno financeiro leva as gravadoras a promoverem a repetição de fórmulas artísticas, o que, por sua vez, redunda numa linguagem musical estereotipada:

\footnotetext{
De posse de todas as condições técnicas de viabilização do disco, as gravadoras invadem o espaço dos artistas e passam a exercer também suas funções; tudo, evidentemente, visando maior controle do produto artístico enquanto produto comercial. Em vez de o artista estabelecer o ajuste entre função artística e função técnica (como na ocasião da bossa nova e da tropicália) tornando sua obra econômica do ponto de vista da informação estética, os homens da empresa que procedem o ajuste assumem a função artística, tornando a obra econômica do ponto de vista comercial. Resultado: estereotipação ( $\mathrm{sic}$ ) da maneira de compor e dos arranjos instrumentais para que possam ser processados em escala industrial. (Arte em Revista, 1984, p. 32)
}

A partir desse argumento podemos compreender a relevância cultural (pretendida) do músico independente no contexto da Vanguarda Paulista. Na medida em que assume as funções técnicas tendo em vista objetivos artísticos, ele promove o reequilíbrio entre as 
funções técnicas e artísticas, o que, por sua vez, abre uma porta para que a canção saia da eterna repetição das fórmulas que já deram certo, promovidas pela gravadora em busca do lucro:

Em suma, a retomada do ajuste entre função artística e função técnica que, de tempos em tempos, corrigia a trajetória da MPB, socorrendo-a de uma estereotipação (sic) total iminente, ocorre hoje pelo lado de fora do sistema de produção industrial, não podendo, portanto, atingi-lo diretamente. Mas é fácil observar que já é incontrolável a estereotipação (sic) generalizada no interior das gravadoras. (Arte em Revista, 1984, p. 33)

O ideal cultural pretendido pelo músico independente era a construção de uma alternativa à repetição de fórmulas e o consequente resgate da criatividade na canção popular. A condição independente promoveria então o reajuste entre a técnica e a arte. A situação da MPB, no final dos anos 1970, segundo a leitura de Luiz Tatit, não era das melhores. A sensação era de estagnação: de um lado, uma situação cômoda para os poucos artistas eleitos pelas gravadoras; do outro, novos artistas e novas propostas não encontravam espaço. Contudo, o pior aspecto dessa estagnação era aquilo que esse autor apontava como estereotipia: a repetição de fórmulas que já deram certo. Nesse cenário, surgia o artista independente como solução para salvar a canção popular de um circuito fechado:

\footnotetext{
Na medida em que o único compromisso de cada artista é com a sua própria concepção de arte, na medida em que não há uma receita prévia a ser seguida, nem a ser inaugurada (para se transformar em posterior camisa de força), na medida em que não há nem mesmo o compromisso com o sucesso de vendas (pelo menos não de acordo com o padrão quantitativo das gravadoras, uma vez que o custo de um disco independente é inferior ao das gravadoras, e portanto ele se paga e dá lucros vendendo um décimo da quantidade mínima para um disco não ser considerado investimento perdido no circuito normal), a liberdade de opção colocada para o músico independente é absolutamente ilimitada. (Arte em revista, 1984, p. 19)
}

O trecho acima, de Iná Camargo Costa, publicado no dossiê de Arte em Revista dedicado aos independentes, dá uma visão ilusoriamente positiva do artista independente. Em 1983, o Lira Paulistana ainda vivia o seu auge e muitos artistas transpareciam otimismo com o circuito independente. Devem ser ressaltadas as imposições e restrições que faziam parte dessa condição. Embora ela seja celebrada como uma atitude libertadora, também é 
verdade que muitos artistas eram independentes por pura necessidade, por falta de oportunidade para realizar o seu trabalho em melhores condições. O depoimento de Tatit, colhido por Daniela Ribas Ghezzi em 2002, portanto já com uma distância crítica em relação aos anos do Lira Paulistana é revelador nesse sentido:

Praticamente, não tinha nenhuma vantagem (em ser independente), só necessidade. Se você quisesse apresentar o seu trabalho, você não tinha outra alternativa. Todos nós fomos empurrados para a condição independente. Você pode perguntar pra qualquer um, mesmo naquela época, se houvesse qualquer proposta de qualquer gravadora - talvez só uma proposta indecente não seria aceita - mas qualquer proposta de gravar o trabalho que a gente estava fazendo, seria aceita imediatamente. Aliás, todo o mundo abandonaria o barco, como fez o Gordo [Wilson Souto Jr.], imediatamente, se tivesse uma proposta concreta de qualquer gravadora. (GHEZZI, 2003, p. 233)

Dar o próximo passo na "linha evolutiva da MPB" e assim ocupar uma posição de prestígio no campo da música popular era, afinal de contas, o objetivo desses artistas, o qual não foi alcançado. A condição independente, tão louvada enquanto postura libertária das "formulas estereotipadas das gravadoras" mostrou-se como sério entrave à circulação das obras desses artistas, que permaneceram conhecidos apenas por um pequeno círculo de estudantes universitários e especialistas em música popular. Diga-se também, que não procede o argumento segundo o qual a crise econômica que atingira o mercado fonográfico, nos anos 1980, e o consequente fechamento das gravadoras para novas propostas estéticas arriscadas fora a causa da exclusão dos independentes, da vanguarda paulista, e do seu restrito sucesso. Como Tatit afirma em seu depoimento acima, não apenas os independentes abandonariam o barco e assinariam com grandes gravadoras se tivessem a chance, como de fato o fizeram. Arrigo Barnabé, desde o início, gravou seus discos com a Ariola, a qual, em 1983, seria adquirida pela Polygram, uma das grandes gravadoras (majors). Itamar Assumpção gravou seu disco Intercontinental! Quem Diria! (1988) pela gravadora Continental, uma das majors. Premeditando o Breque gravou três álbuns com a EMI-Odeon, também uma das majors. Ou seja, se eles não alcançaram o sucesso com o público amplo, culpar a falta de apoio das gravadoras não é um argumento inteiramente válido.

O que se pretende com esses parágrafos é tão somente explicitar a posição a partir da qual Arrigo Barnabé e os grupos da Vanguarda Paulista produziram suas obras, bem como a posição e a visão que eles se atribuíam. Seria quase impossível dar uma explicação irrefutável do motivo que leva determinado artista a não alcançar o sucesso do público 
amplo, o que não nos impede de levantar algumas hipóteses. Retomando o argumento de Tatit a respeito do ajuste entre funções artísticas e funções técnicas na MPB, poderíamos dizer que, se há o problema da estereotipia quando as gravadoras assumem a função artística, também pode haver o problema da dificuldade de comunicação em obras que, por "excesso" de liberdade criativa, enveredam por linguagens e convenções novas demasiado distantes do grande público. Conforme o argumento de Flo Menezes apresentado no primeiro item, ocorre nas vertentes vanguardistas o risco de isolamento do artista perante o público: faltalhe a gramática para compreender linguagens cada vez mais individualizadas. Também a vanguarda paulista experimentou "gramáticas" da canção por vezes muito sofisticadas, irreverentes, criativas, mas quase sempre de difícil comunicação "à primeira escuta". Na famosa declaração do produtor Pena Schmidt, os artistas da vanguarda paulista eram por demais "indigestos" para o público amplo (DIAS, 2006). Mas ainda aqui pouco se sustenta o argumento da resistência heroica da integridade artística ante a mediocridade do mercado. Arrigo Barnabé no seu álbum Suspeito colocou em prática todas as receitas possíveis de sucesso para alcançar o grande público, sucesso que mesmo assim não veio ${ }^{48}$. $\mathrm{O}$ mesmo pode ser dito de Itamar Assumpção, do grupo Premeditando o Breque, e assim por diante. Os membros da vanguarda paulista simplesmente não alcançaram, ou não souberam alcançar o sucesso por eles próprios desejado. ${ }^{49}$.

\section{O fim do Lira Paulistana e a dispersão da Vanguarda Paulista}

No final de 1982, por ocasião do terceiro aniversário do Lira Paulistana, o teatro anunciou uma parceria com a gravadora Continental. O contrato, para os donos do teatro, era a oportunidade de finalmente se profissionalizarem enquanto gravadora e distribuidora, a possibilidade de dar à produção independente paulistana uma projeção nacional. Assim foi anunciado o acordo Lira/Continental, em 1983:

\footnotetext{
48 «Para divulgar esse LP, ele participou do programa do Chacrinha e do programa da Xuxa, ambos na Rede Globo (CAVERSAN, 1988). Quando apresentava "Uga Uga" (Arrigo Barnabé), carro-chefe do disco, bananas eram entregues para o público, para os jurados». Walter Garcia. Clara Crocodilo e Nego Dito: dois perigosos marginais? Antíteses (Londrina), v. 8, 2015, p.14.

${ }^{49}$ Lembro-me de uma anedota que me foi contada por meu professor de guitarra quando adolescente (por volta de 2004), a qual, segundo ele, fora dita por um importante produtor musical da Som Livre: "para obter sucesso, uma música tem de servir para uma dessas três coisas: para dançar, para meditar ou para transar. Se uma música não serve para nada disso, ela não serve para m. nenhuma". Esse é o caso das canções da Vanguarda Paulista. Elas certamente não são adequadas para a dança. Para meditar, seria uma estranha contemplação do mal-estar em São Paulo. Para transar, bom, aguardo relatos de alguém que tenha tido relações ao som de "sabor de veneno". Ou seja, eram canções que se afastavam demais não apenas das convenções da canção brasileira, mas também dos usos nos quais a canção está normalmente inscrita.
} 


\begin{abstract}
Há um ano, logo depois de seu terceiro aniversário, o Lira inicia uma nova etapa na produção de discos. É que, ao realizar um acordo com a Continental (a maior gravadora de capital totalmente nacional), coloca no mercado - além dos discos já produzidos pelo Lira - uma nova relação entre artistas e empresa. Neste acordo, a independência dos grupos/artistas é totalmente mantida passando seus discos a ter uma distribuição nacional. Os discos anteriores produzidos pelo Lira e pelos grupos já estão sendo distribuídos em todo o país e alguns outros já foram produzidos pelo Lira/Continental e os artistas associados. (Arte em revista, 1984, p. 37)
\end{abstract}

O Lira Paulistana, representado na Continental por Wilson Souto Jr., que desse momento em diante não mais trabalharia no teatro, e sim para a Continental, procurou fazer valer na gravadora os interesses dos artistas. Wilson redigiu junto à gravadora um contrato que dava ao artista a propriedade do fonograma, a numeração dos discos e a não vinculação do artista à gravadora (Ghezzi, 2003, p.175). Todos esses pontos eram reivindicações comuns dos músicos, e até hoje o são. O contrato dava também ao artista plena liberdade estética, da escolha do repertório à arte da capa, a divisão dos lucros - o artista receberia $50 \%$ do total das vendas, enquanto que a prática na época era o pagamento de 5 a $7 \%$ de comissão por unidade vendida. Além disso, a Continental deixaria disponível sua infraestrutura para a produção e a comercialização dos discos (OLIVEIRA, 2002, p.88).

O contrato vigorou por menos de um ano, ao longo do qual foram produzidos 22 discos. Tanto para os artistas quanto para a gravadora foi um estrondoso fracasso. Da parte dos artistas, partiram reclamações de falta de estrutura comercial para trabalhar com o novo produto, de que não havia investimento suficiente em divulgação, distribuição e marketing para fazer com que o trabalho independente circulasse em públicos mais amplos. A gravadora havia buscado o Lira Paulistana justamente por estar interessada no prestígio da música independente. Isso lhe interessava por ser uma gravadora até então restrita aos nichos mais populares de mercado. Conforme expôs Riba de Castro, a Continental se beneficiaria do prestígio do selo Lira e este, por sua vez, teria acesso à divulgação e distribuição de seus trabalhos em nível nacional. Porém, a gravadora não se teria comprometido com a música independente (CASTRO, 2014, P. 152). Já Wilson Souto Jr., que até então era o principal articulador do Lira Paulistana, também expôs a sua versão dos fatos. Para ele, embora a gravadora Continental não estivesse preparada para trabalhar com os independentes, os artistas também tiveram sua parcela de responsabilidade no fracasso do acordo: 
Era um contrato que dava poder para o artista como gestor da obra dele, sendo que o artista não é o melhor gestor. Era um contrato que, todos os fonogramas gerados nesse período, quando saíssem do catálogo, eram propriedades do artista. Então a Continental devolveu todos esses discos, e sabe Deus onde esses discos estão hoje [...] A Continental, por outro lado, nos mostrou que, primeiro: não estava preparada para distribuir esse segmento de artistas. Ela estava especializada em música popular, no sentido de grande massa. Então foi péssimo. [...] Os artistas todos tiveram a oportunidade de gravar novos discos com uma tecnologia bem melhor e financiados pela Continental, alguns desses artistas tiveram, a partir desse momento, acesso à carreira, que acabou sendo interrompida na gravadora seguinte, por exemplo, depois que o Premeditando o Breque fez na Continental com o "Quase Lindo", que tocou o "São Paulo, São Paulo", quase 18 mil discos (talvez tenha sido a melhor performance dentro dos discos), ele imediatamente foi contratado pela EMI, e abandonou esse maravilhoso acordo que propiciava a eles a propriedade da obra, enfim, toda aquela bandeira que o contrato refletia, no primeiro momento que alguém convidou para um processo tradicional "Tchau, tô indo". O contrato (da Continental) não prendia o artista à gravadora. E isso me mostrou claramente o seguinte: o artista, na verdade, é uma bandeira que não existe. Me parece que é muito mais um muro das lamentações infundadas, porque no fundo o que o cara queria ser, ou algumas dessas pessoas queriam era ser artistas como todos os artistas convencionais da música brasileira (GHEZZI, 2003, p.177).

O fracasso do acordo Lira/Continental significou também o fracasso da proposta independente encabeçada pelo Lira Paulistana. As bandas que até então vinham numa trajetória ascendente não alcançaram a almejada projeção nacional, e o teatro perdeu para a Continental seu principal articulador. Após a saída de Wilson Souto Jr. em 1983, teve início a segunda fase do teatro, já bastante distinta dos primeiros anos. Com a debandada dos precursores, o teatro foi ocupado por bandas ascendentes da cena punk-rock, como Ratos de Porão, Cólera, Inocentes e Ira. As brigas dentro do teatro tornaram-se cada vez mais frequentes e o público cada vez menor. Progressivamente esvaziado, as dificuldades financeiras aumentaram e o teatro fechou suas portas em 26 de setembro de 1986.

Com o fechamento do Lira Paulistana as bandas da primeira fase perderam o espaço catalisador e, embora já fossem grandes demais para o teatro, acabaram por perder a vitalidade do período Lira. Pulverizou-se a efervescência musical concentrada num ponto geográfico da cidade. Integrantes do Rumo, do Premeditando o Breque e do Língua de Trapo iniciaram outras carreiras, apesar de apresentações esporádicas dessas bandas ocorrerem até hoje. Arrigo Barnabé e Itamar Assumpção (falecido em 2003) persistiram na música, mas já 
sem a mesma notoriedade de antes. O depoimento de Suzana Salles, concedido a Laertes Fernandes de Oliveira, em julho de 2002, é revelador da importância do Lira Paulistana enquanto espaço físico aglutinador:

\footnotetext{
Ainda temos um circuito alternativo na cidade (como o SESC, o Itaú Cultural, Crowne Plaza, Teatro da Umes), com muito mais recursos técnicos, que tem seu público, tem coisas novas (...) só que está pulverizado. E quem não se liga e não vai atrás, não percebe. A criação está aí viva, não se esgota e não sei mesmo se hoje tem que ter uma localização específica para criações novas. (OLIVEIRA, 2002, p.120)
}

Certamente, os artistas não obtiveram a repercussão nacional almejada, não foram bem-sucedidos em transladar sua atuação, do circuito independente e do restrito público universitário, para o público amplo. No entanto, sua produção musical encontra até hoje repercussão nos meios universitários de São Paulo e, progressivamente, de outros estados.

\section{Conclusão}

Ao longo deste capítulo, procuramos fazer uma introdução ao universo das canções de Arrigo Barnabé, das canções dos seus companheiros de geração da vanguarda paulista, bem como da posição independente, na qual eles foram obrigados a produzir seus discos. Como vimos, há uma proximidade semântica nas canções quando se considera o modo como a cidade figura: seja com agressividade ou com humor, há um há mal-estar que se faz sempre presente. Na cidade dos luminosos e fliperamas, do ônibus que não espera, das enchentes, das prostitutas, do trabalho... No entanto, embora essa representação do urbano que ao mesmo tempo recupera a tradição da canção brasileira e difere dela, tanto pela dose de negatividade quanto de experimentação formal, funciona ao mesmo tempo como um comentário da situação do músico independente e da "linha evolutiva" da canção. Ou seja, essas canções (e sobretudo as que figuram no álbum Clara Crocodilo) não são apenas ou preponderantemente uma representação do submundo da grande cidade ou da história da canção. Elas abarcam e mesclam esses dois aspectos. Mesmo o relativo fracasso da vanguarda paulista é também um elemento importante, contribui para sedimentar mais uma camada simbólica, de significados, à relevância cultural que o álbum em questão teve: ele traz esse elemento para a própria obra ao referir-se, na introdução da última faixa ao álbum como um "disco empoeirado" esquecido em um sebo. 
Em suma, há um amplo espectro de conotações das canções de Clara Crocodilo que precisa ser desfiado, investigado e, numa etapa posterior, usado como "sonda" para mergulhar nas representações que a canção popular fez do Brasil, mais especificamente, do vir a ser de um Brasil moderno. Precisamos então escutar mais detalhadamente as canções. Mas, para isso, precisamos também definir melhor a canção enquanto objeto de estudo sociológico. Este é o objetivo dos próximos dois capítulos, antes de propriamente escutar Clara Crocodilo. 


\section{Capítulo II: A semiótica da canção de Luiz Tatit}

A música não é um objeto de estudo propriamente novo para a sociologia. Já em 1921 foi publicado o estudo de Max Weber sobre os fundamentos racionais e sociológicos da música. Nas décadas de 1930 e 1940, Theodor Adorno publicou ensaios até hoje polêmicos mas ainda assim fundadores da abordagem sociológica da música popular: On Jazz (1936), On Popular Music (1941). Na segunda metade do século XX, e no Brasil, sobretudo a partir dos anos 1980, multiplicaram-se os estudos sobre a música e a canção popular feitos a partir das abordagens das ciências sociais. Diga-se de passagem, no contexto internacional e também nacional, acadêmicos oriundos dos departamentos de musicologia encontraram nas ciências sociais e nos departamentos de estudos culturais espaço para realização de pesquisas sobre a música popular, então desconsiderada como objeto digno de estudo musicológico ${ }^{50}$. O seu estudo nos departamentos de sociologia, história, comunicação, letras, etc., justificou-se na maioria das vezes, por conta da relevância sociocultural dessa forma de manifestação (por sua presença nos meios de comunicação de massa, por ser $a$ mercadoria da indústria cultural, por ser parte de manifestações de protesto e contracultura, como forma de afirmação de identidades...), e não por conta de um «valor estético» digno de apreciação acadêmica, tal como acontece com as obras tradicionalmente consideradas pela musicologia, a música de arte, ou erudita. Decorre dessa geopolítica acadêmica que a tônica dos estudos da música popular recaiu muito mais sobre a sua dimensão sociocultural e socio-histórica do que sobre a análise de suas propriedades intrínsecas, ou seja, das obras em si mesmas ${ }^{51}$.

Acontece que, mesmo para uma avaliação da dimensão histórica e social da música popular, algum conhecimento e parâmetro de análise das suas formas se faz necessário, uma vez que se assuma que é ela o objeto de estudo ${ }^{52}$. É por isso que dedicaremos este capítulo à reconstrução daquilo que consideramos os pontos cardeais da semiótica da canção de Luiz Tatit. Somos da opinião de que nenhum outro pesquisador forjou um leque de conceitos ao mesmo tempo tão abrangente, profundo e coerente para a análise da canção popular, como ele fez. Ainda, estudá-lo conta com a vantagem, para nós decisiva, de ele de ter desenvolvido seus conceitos na e pela análise sistemática da história da canção popular brasileira. Os nove

\footnotetext{
${ }^{50}$ Anne Danielsen. Aesthetic Value, Cultural Signifiance, and Canon Formation in Popular. In: C., Dahmen, U. og R. Grossman PopMusicology. Perspektiven der Popmusikwissenschaft. Ed. Bielefeld. No Brasil, ocorre o mesmo fenômeno. O próprio percurso de Luiz Tatit, que discutiremos adiante, é revelador nesse sentido. Veja-se que, até hoje, número significativo dos estudos sobre música popular são feitos nos departamentos de ciências humanas.

${ }^{51}$ Idem.

${ }^{52}$ No âmbito internacional, Simon Frith, Richard Middleton e Bracket foram os primeiros acadêmicos que se defrontaram com a análise da música popular. [indicar em que obras]
} 
livros até hoje publicados por Luiz Tatit, dedicados à semiótica da canção, revelam um esforço quase obsessivo de forjar conceitos e parâmetros científicos que auxiliem em sua análise, baseados na tradição semiótica francesa fundada por Algirdas Julien Greimas (19171992). O resultado dessas décadas de pesquisa são conceitos consistentes para a análise e reconstrução dos sentidos verbais e não verbais que a canção gera a partir de suas estruturas. Uma vez que ela é também o nosso objeto de estudo, a reconstrução a seguir mostrou-se não apenas proveitosa, mas incontornável.

\section{Reconhecendo a canção: entoação e junção de melodia e letra}

A primeira tarefa daquele que se propõe a abordar a canção como objeto de estudo, seja de um ponto de vista musicológico, histórico ou sociológico, é conhecer a especificidade do objeto, aquilo que o distingue de outras manifestações culturais. Não havendo um ponto de partida suficientemente claro, corre-se o risco de avaliar o objeto com parâmetros que lhe são alheios. Isso ocorreu diversas vezes na abordagem acadêmica da canção popular. Essas pequenas peças, compostas na maioria dos casos com recursos musicais muito simples, não poderiam ser bem-vistas por aqueles que avaliam a música a partir dos parâmetros de inovação e complexidade do uso dos materiais musicais: harmonia, melodia, ritmo, andamento, dinâmica, instrumentação etc. A sociologia da música proposta por Max Weber, por exemplo, preocupa-se com a análise do processo de racionalização dos materiais musicais na história do ocidente: como se desenvolveram as escalas, os instrumentos e formas de notação musical, e como esses processos possibilitaram formas de pensar, compor e executar as obras musicais. Tudo isso colocado na chave do desenvolvimento de um racionalismo específico que só no ocidente teria se manifestado. (Cf. Weber, 1921) O pesquisador que partir desse posicionamento teórico estará interessado, sobretudo, em obras significativas a partir da perspectiva da racionalização cada vez mais complexa dos materiais e das práticas musicais. A canção e suas formas harmônicas básicas seriam de pouco ou nenhum interesse. Richard Taruskin, um dos grandes musicólogos do século XX, mesmo sendo completamente avesso às concepções (por ele consideradas) " arrogantes » de Theodor Adorno sobre a música popular, escreveu sua vasta história da música ocidental ${ }^{\mathbf{5 3}}$ focalizando o desenvolvimento das formas e o uso dos materiais musicais pelos grandes compositores, o arco que vai dos primórdios do sistema tonal à sua desintegração no século XX com o dodecafonismo. Claro está que a canção popular, fenômeno de impacto social no

\footnotetext{
${ }^{53}$ Richard Taruskin. The Oxford History of Western Music. Oxford: Oxford University Press, 2005.
} 
século XX muito maior que o do dodecafonismo, ocupa um lugar mais que secundário nessa história $^{54}$. A obra de Luiz Tatit destaca-se, justamente, pelo esforço em alcançar uma forma específica de avaliação da canção. Se elas são geralmente pobres quando julgadas a partir de parâmetros musicais e literários, mas ainda assim constituem um fenômeno sociocultural fundamental do século XX, talvez o problema não esteja na ignorância e falta de bom gosto do público, mas sim nos instrumentos analíticos utilizados.

Luiz Tatit ingressou no curso de Música da Escola de Comunicação e Artes da USP em 1971, onde, segundo ele, predominava a seguinte concepção sobre o que é música «séria»: «A ideologia do Departamento chamava-se Willy Corrêa Oliveira (1938), compositor erudito que, à época, via na música de vanguarda uma forma de revolução possível pelo artista» (TATIT, 2014, p.25). Segundo Tatit, Willy Oliveira considerava haver relação entre a música de vanguarda e a revolução social: «o princípio de transformação necessário a qualquer revolução deve estar inscrito, por antecipação, na própria forma da produção artística. 'Forma', nesse sentido, correspondia, às vezes, ao plano de expressão (significante) das linguagens estéticas e, às vezes, à estrutura de organização tanto do plano da expressão como do conteúdo» (TATIT, 2014, p. 27) ${ }^{\mathbf{5 5}}$. Óbvio que a canção popular era, nesse contexto, considerada uma depravação das formas folclóricas adaptadas ao mercado de consumo (Idem).

Em 1974, Luiz Tatit e outros estudantes formaram um grupo de estudos e discussão sobre a música popular brasileira em decorrência da falta de espaço dentro do Departamento de Música para esse tipo de reflexão. Posteriormente ${ }^{56}$, nos anos 1980, esse grupo tornouse o grupo Rumo, banda integrante da chamada Vanguarda Paulista. Pesquisa da canção popular e desejo de compor algo significativo dentro dessa linguagem marcaram a carreira do conjunto e, principalmente, de Luiz Tatit, que, paralelamente à graduação em Música, viria a cursar graduação em Letras, na mesma universidade. Como já foi dito no capítulo anterior, o grande insight da Tatit é que o compositor de canções não trabalha a partir de um

\footnotetext{
${ }^{54}$ Ironicamente, Adorno concede muito mais atenção à canção popular do que Taruskin.

55 Diga-se de passagem que Willy Correa foi integrante do grupo Música Nova, grupo cujas concepções estéticas influenciaram diretamente o tropicalismo. Não apenas no que diz respeito a questões propriamente musicais, como arranjo, texturas e formas, como também na concepção de revolução social por meio da revolução estética. Mais tarde, artistas da Vanguarda Paulista como Arrigo Barnabé e o grupo Rumo, do qual o próprio Luiz Tatit fazia parte, também foram influenciados por essas concepções.

56 "Nos anos 1980 é que virou uma banda. O Rumo era composto por dez pessoas, quase todas da USP, o que não era um pré-requisito, coincidia por causa do coleguismo. Tatit estudava na ECA, seu irmão Paulo e o baterista Gal Oppido, na FAU. O Zecarlos Ribeiro estudava na Arquitetura de Mogi. Pedro Mourão fazia Música na ECA. Helio Ziskind era da Psicologia, pediu transferência e foi fazer Música na ECA. A Ciça Tuccori era da ECA." Sonia Alem Marrach. Música e universidade na cidade de São Paulo: do samba de Vanzolini à Vanguarda Paulista. São Paulo: Editora Unesp, 2011. p. 141.
} 
pensamento musical ou literário, mas do manejo da entoação, encontrando formas de dizer nas linhas melódicas.

Ao colocar o manejo da entoação como a especificidade da canção, Tatit desvincula essa linguagem dos parâmetros musicais e literários. Não que eles não sejam significativos, mas a linguagem especificamente cancional emerge de uma nova unidade de sentido, decorrente da união desses dois elementos: melodia e letra. Se uma canção for considerada de pouco valor musical ou literário, pouco importa, pois a especificidade do artesanato da canção, que subjaz a todas as suas vertentes, não é o mesmo que o da música ou o da poesia. Essa especificidade reside nas formas de promover o encontro da letra com a melodia, criando assim, formas de dizer, entoações, melodias que encapsulam as frases assim como aquelas que proferimos na fala cotidiana. Só que agora, o modo de dizer entoativo é fixado pela forma musical. Segundo Tatit, fazer uma canção é converter discursos orais, os quais possuem parâmetros sonoros instáveis, em canções estabilizadas do ponto de vista musical (TATIT, 2014, p.230). O manejo das formas entoativas que surgem da união entre letra e melodia (entre material linguístico e material musical) garantem à canção um estatuto popular tanto no momento de produção quanto no da recepção: isso permite que pessoas sem formação musical criem canções, assim como facilita que o público leigo as assimile. O ouvinte, quando «reconhece» uma canção, reconhece uma fusão particular de melodia e letra, ainda que não saiba qual é a sua base harmônica ou qual escala musical está sendo usada. Mesmo o registro autoral das canções incide sobre letra e melodia.

A entoação cancional, na qual a forma sonora de um modo de dizer é estabilizada com parâmetros musicais (sobretudo ritmo, altura e duração), é composta por duas forças: uma de continuidade e outra de segmentação. A força de continuidade provém do fluxo da melodia, da sustentação de notas musicais na emissão das vogais. A força de segmentação provém do recorte que as palavras operam no som. Podemos pensar isso pelo viés musical: as notas musicais duram uma determinada quantidade de tempo, ao passo que a frequência com que são interrompidas configura o ritmo - toda «batida» do ritmo opera o fim de uma duração e o começo de outra. Essa dinâmica, vista pelo viés linguístico, nada mais é do que a silabação. Nas palavras, as durações das vogais são interrompidas pelas consoantes, formando uma cadência rítmica de abertura e fechamento dos sons. A entoação na canção surge do encontro das cadências rítmicas: da melódica com a silábica. Segundo Tatit, o cancionista «decompõe a melodia com o texto, mas recompõe o texto com a entoação» (2012, p. 10). 
Não importa se o cancionista partiu de uma melodia e criou um texto para recobri-la, ou se ele já tinha um texto pronto e compôs uma «cama» harmônico-melódica para acomodálo. De um ou outro ponto de partida, a melodia adquire um valor de entoação (ou seja, uma sequência de notas musicais adquire significado como um modo de dizer plausível) e o texto contrai relações musicais (ou seja, o modo de dizer o texto adquire uma forma e um sentido musical). No processo de composição, há sempre um momento em que a instabilidade entoativa se musicaliza e em que frases musicais se convertem em unidades entoativas por força do recorte linguístico (TATIT, 2016, p. 104). Se o cancionista se depara com uma melodia pronta, seu trabalho será o de desvendar a força entoativa contida nas ascendências e descendências das notas musicais. Quais frases poderiam ser ditas valendo-se dessas ascendências e descendências melódicas? ${ }^{57}$ A melodia, quando trabalhada na canção, transforma-se num conjunto de virtualidades figurativas (modos virtuais de dizer) que podem ou não ser atualizadas pelo letrista ${ }^{58}$. Mas não basta que se "cole" uma letra numa melodia, é preciso que a entoação resultante seja plausível, que convença o ouvinte da plausibilidade daquele modo de dizer, assim como a expressão facial de um ator deve ser convincente do sentimento que ele quer representar ${ }^{59}$. O encontro da melodia com a letra promove a re-presentificação de modos de dizer, facilmente reconhecíveis para os ouvintes, uma vez que eles também são falantes ${ }^{60}$ (TATIT, 2016, p. 79).

Talvez seja interessante transcrever um depoimento de Luiz Tatit sobre o seu próprio processo de composição, ou melhor, da sua prática de união de melodia e letra:

\footnotetext{
Componho ao violão, algumas direções de melodia são sugeridas pelo manejo do instrumento. Considero que essas direções são boas quando definem um modo de dizer, mesmo que eu ainda não saiba (e geralmente não sei) o que exatamente direi; ou seja, quando já posso dizer «frases-monstro» (frases verbais que não serão aproveitadas) que servem para testar a naturalidade da entoação. Tudo isso antes de ter ideia do tema, mas já lançando fragmentos linguísticos que poderão ser embriões de possíveis temas definidos mais tarde. Os breves encadeamentos harmônicos ou mesmo uma determinada batida rítmica podem contribuir bastante para a estabilização desse material que, nessa fase, é muito pouco consistente. [...] Essa combinação de batida harmônica no violão e melodia ainda meio entoativa,
}

\footnotetext{
${ }^{57}$ Claro que esse processo não é feito de forma necessariamente consciente pelo cancionista.

58 No livro Estimar Canções (2016), Tatit faz um trabalho magistral em demonstrar como cancionistas interpretam as linhas melódicas em termos de entoação e recobrem o mesmo trecho melódico com diferentes frases linguísticas.

59 Voltaremos a isso no item Ilusão enunciativa.

${ }^{60}$ Claro está que Tatit trata das tendências mais fortes na linguagem da canção. Sem dúvida podemos encontrar casos concretos que se afastam dessa tendência.
} 
dizendo frases-monstro, pode durar dias ou meses, até que uma letra coerente comece a sair. (TATIT, 2014, p. 143)

O autor argumenta que a maioria dos cancionistas trabalha do mesmo modo, partindo da melodia e construindo modos de dizer, ao passo que aquilo que de fato é dito na letra é definido apenas na etapa final $(2014$, p. 212). Isso talvez explique o grande número de letras que não fazem sentido algum, diria um leitor malicioso. Porém, mesmo o cancionista mais celebrado pela qualidade literária de suas letras, Chico Buarque, parte da melodia:

\footnotetext{
A palavra não aparece antes da música, e sim depois, mesmo quando eu faço uma música sozinho. Nunca escrevi uma letra de música antes da música existir [...] Muitas vezes a palavra aparece antes do sentido da letra. As vezes uma letra bonita começa por uma palavra, uma palavra que é puxada pela melodia. É muito comum os parceiros cantarolarem a música, e quase que existe uma onomatopeia no que eles cantam. Cada som muda uma palavra. Essa palavra é a chave para o verso, que pode ser a chave para a letra toda. (BUARQUE apud TATIT, 2014, p. 213)
}

Nessa operação de juntar melodia e letra, na qual a fala cotidiana - irregular e instável - adquire a fixidez da forma musical, e na qual a linha melódica adquire as conotações de um modo de dizer, há a inversão do que ocorre no cotidiano. Nesse caso, o foco de atenção recai sobre o conteúdo da fala, e não em seu envelope sonoro. Quando ouvimos uma frase, rapidamente dispensamos a sua sonoridade para melhor assimilar seu conteúdo abstrato. Tanto melhor ela cumpre sua função utilitária de comunicação quanto mais rapidamente passamos do som ao conteúdo. A arte da canção é a transformação artística desse material, é a transformação da entoação em algo digno de ser retido, em forma perene, artística.

Portanto, a união de melodia e letra é o núcleo da canção, aquilo que perfaz a sua identidade; a prática de união melodia e letra é o artesanato específico do cancionista. É isso que faz da canção uma linguagem específica, distinta da música erudita e mesmo da música popular instrumental. Qualquer análise da canção deve principiar pelo mapeamento do modo de união de melodia e letra.

\section{Modos de unir melodia e letra: tematização, passionalização, figurativização e musicalização}

Com os modos de unir melodia e letra, constituem-se formas de persuasão do ouvinte, ou seja, formas de engajá-lo, envolvê-lo nos conteúdos transmitidos pela canção. O conjunto desses modos de persuasão, Tatit chama de «gramática da canção», o conjunto de 
leis que permitem apreender e compreender uma linguagem (2007, p. 19). A unidade básica dessa gramática é a sílaba, pois é justamente nas formas de incidir sobre a sílaba que a canção produz as suas formas de persuasão. Quando se prolongam as vogais, a canção tende a assumir um andamento mais lento, o percurso da curva melódica tende a ser valorizado em cada um de seus graus (notas), sobretudo na emissão e sustentação de notas agudas. Essa é a forma de união entre melodia e letra mais propícia para a representação de estados passionais, as assim chamadas canções lentas. Quando se reduz a duração das vogais e o acento recai sobre o ataque das consoantes, a melodia tende a assumir um andamento mais rápido. Não se valoriza mais a sustentação de cada uma das notas da curva melódica, mas sim o pulso rítmico que ordena a melodia, configurando temas melódicos que se repetem insistentemente. A pulsação de temas rítmicos-melódicos é propícia ao retrato de sentimentos eufóricos e à descrição de ações. Ao primeiro modo de persuasão Tatit chama de passionalização, ao segundo, de tematização. Em cada uma dessas formas, o compositor trabalha as vogais e consoantes para a representação de uma disposição interna, valorizando ora as alturas e durações das notas, ora os ataques rítmicos e a configuração de temas.

Evidentemente, ambas as tendências estão sempre presentes. O que distingue as formas de união entre melodia e letra é a dominância ou recessividade dessas formas de junção: não há, nem poderia haver, melodia feita apenas de ataques rítmicos, assim como também não há (embora seja teoricamente possível) melodia que seja apenas duração de notas, sem pulsação rítmica. Isso seria como um idioma no qual há apenas consoantes ou apenas vogais. O que ocorre é que a dominância ou recessividade de um desses modos determinará o foco de produção de sentido, o que, ao mesmo tempo, propicia ou dificulta a representação de determinados sentimentos (ou melhor, estados fóricos, como veremos adiante). Ou seja, e aqui chegamos a um dos pontos fundamentais da semiótica enquanto proposta de ciência, existem homologias entre a forma de expressão e a forma do conteúdo. No caso da canção, existem homologias observáveis entre o ataque rítmico das consoantes e a duração das vogais, de um lado, e o conteúdo transmitido pela canção, de outro. Segundo Luiz Tatit (2007), a escolha entre tematização e passionalização na melodia determina também se o compositor valorizará a conjunção imediata do sujeito representado na canção com o seu objeto de desejo ou se ele valorizará a conjunção à distância, ou seja, se ele valorizará o percurso de busca e espera pelo objeto (ou pessoa) desejado. A aceleração e reiteração periódica do pulso rítmico propicia a celebração de identidades entre sujeito e objeto: na música popular brasileira há muitas canções que celebram a união eufórica do sujeito com o seu objeto de valor, seja ele a morena, a beleza, a baiana, a natureza, ou mesmo 
a celebração do próprio gênero musical - o samba, o rock, o axé, o forró, o funk etc. A desaceleração e a valorização dos contornos melódicos propicia temas passionais, onde sujeito e objeto estão em disjunção, mas reafirmam o laço de conjunção à distância. Vejamos isso em maior detalhe.

\title{
2.1 Tematização
}

Na canção onde predomina a forma temática de união entre melodia e letra, o grande "assunto" da melodia é a afirmação dos seus próprios temas. Essa característica da forma de expressão ressoa na forma do conteúdo: se o ritmo marcado denota de maneira clara qual é o gênero musical em questão (pois é sobretudo o ritmo que distingue o samba, a marchinha, o forró, o bolero, o rock, o baião etc.) a letra geralmente exalta o próprio gênero ou o seu personagem símbolo. Trata-se de uma forma de persuasão somática do ouvinte, onde as pulsações regulares do ritmo seduzem o corpo para a dança, seduzem os movimentos corporais a entrarem em consonância com a música, ao passo que a letra confirma esses sentimentos eufóricos. Letra e melodia seduzem o ouvinte a entrar em conjunção com os valores exaltados:

\begin{abstract}
A tematização melódica é um campo sonoro propício às tematizações linguísticas ou, mais precisamente, às construções de personagens (baiana, malandro, eu), de valores-objetos (o país, o samba, o violão) ou, ainda, de valores universais (bem/mal, natureza/cultura, vida/morte, prazer/sofrimento, atração/repulsa). Por intermédio da tematização, o cancionista pode exaltar a sua pátria (Aquarela do Brasil, Brasil Pandeiro, País Tropical), sua gente (Morena Boca de Ouro, O Que é Que a Baiana Tem?), sua música (Samba da Minha Terra, Baião), a natureza (Águas de Março, Refazenda); pode produzir os gêneros dançantes (marchinhas de carnaval, rock jovem, samba de gafieira, xote para forró etc.) [...] Enfim, a tendência à tematização, tanto melódica como linguística, satisfaz as necessidades gerais de materialização (linguístico-melódica) de uma ideia. Cria-se, então, uma relação motivada entre tal ideia (natureza, baiana, samba, malandro) e o tema melódico erigido pela reiteração. (TATIT, 2012, p. 23)
\end{abstract}

Trazemos abaixo três exemplos de curvas melódicas onde predomina a tematização. É claramente possível perceber na representação gráfica ${ }^{61}$ elaborada por Tatit, o modo como a melodia cria "desenhos" estruturados (temas) que se repetem. Nos quadros 1 e 2 temos os

\footnotetext{
${ }^{61}$ Esses quadros foram criados por Luiz Tatit para representar a união entre letra e melodia, distribuindo as sílabas no campo da tessitura (campo que vai da nota mais grave à nota mais aguda executada na canção). Cada linha corresponde a um semitom.
} 
versos iniciais de Aquarela do Brasil de Ary Barroso. Trata-se de um caso exemplar daquilo que Tatit chamou de materialização linguístico-melódica de uma ideia. O samba de Ary Barroso propõe um «vínculo corporal entre o Brasil e o brasileiro» (TATIT, 2012, p.101): o ritmo e a melodia convidam à dança, à celebração, ao passo que a letra desfila características símbolo do Brasil. É a própria concretização musical-linguística de uma ideia de brasilidade que se traduz também em estímulos corporais:

Aquarela do Brasil, Ary Barroso (TATIT, 2012, p. 99)

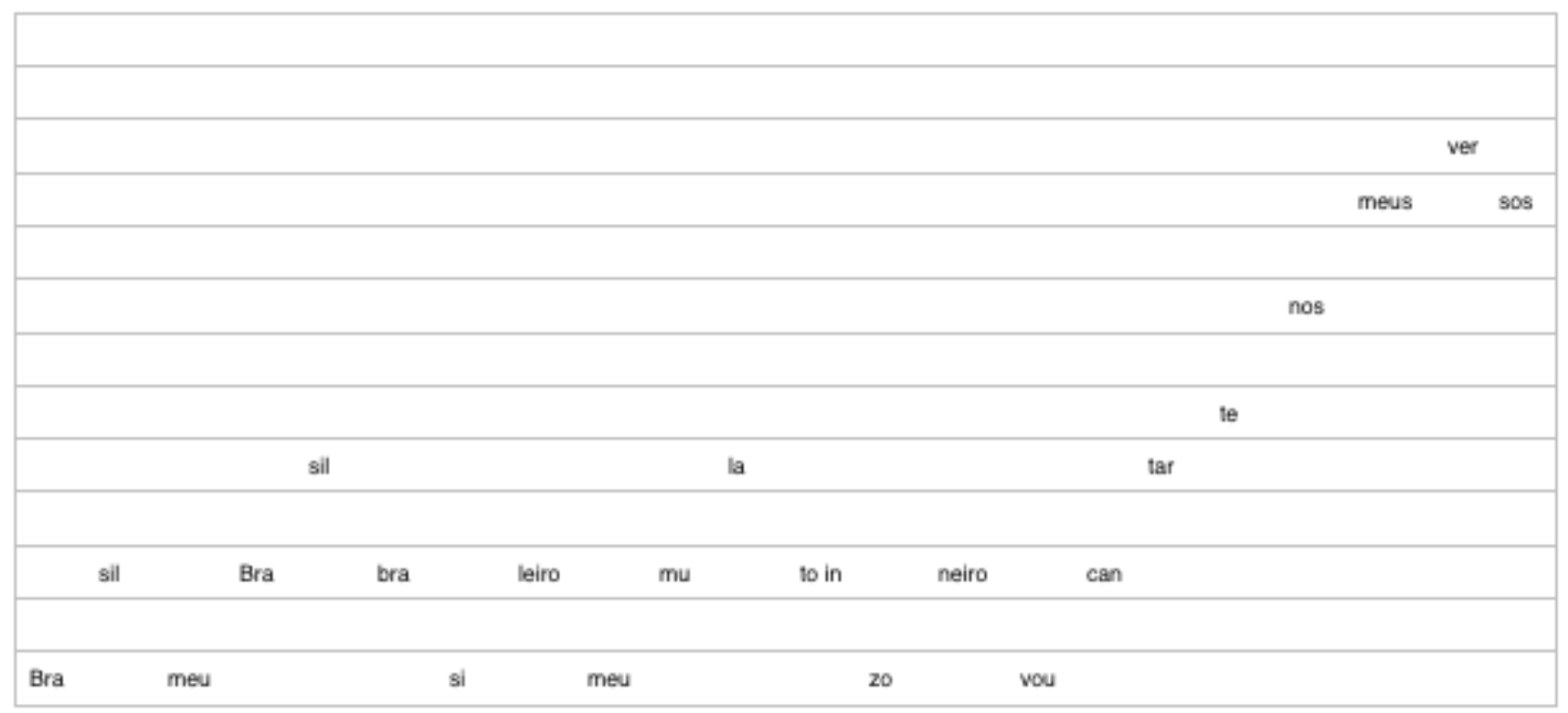




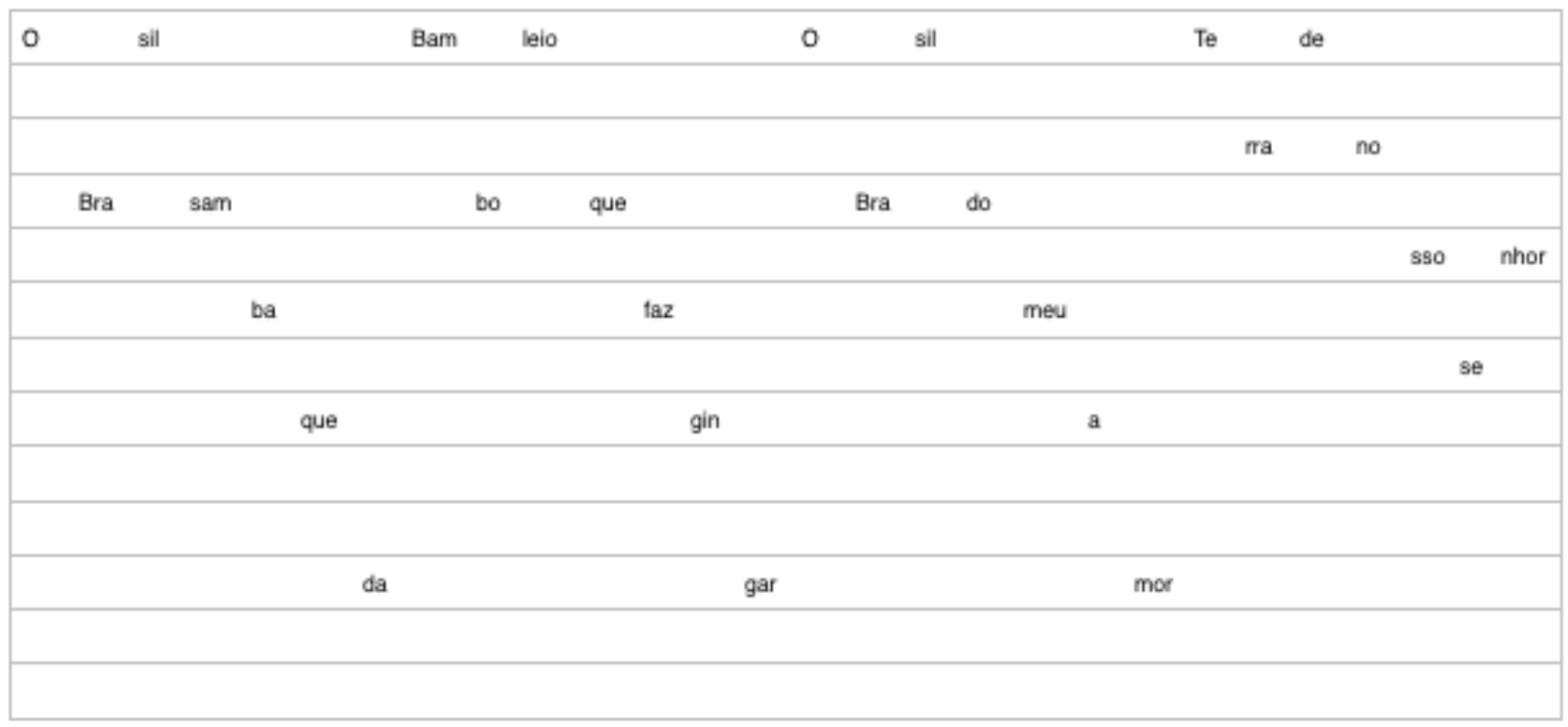

O segundo exemplo são os versos que compõem o refrão de $O$ que é que a baiana tem? de Dorival Caymmi. Mais uma vez se observa a criação de temas bem delineados que se repetem, sugerindo um movimento concêntrico. A letra descreve os adornos do traje típico da baiana, sugerindo também o seu movimento corporal. Letra e melodia exaltam euforicamente as qualidades da baiana, mais uma vez configurando uma ideia-símbolo que se une à disposições físicas:

O que é que a baiana tem, Doryval Caymmi (TATIT, 1997, p. 88)

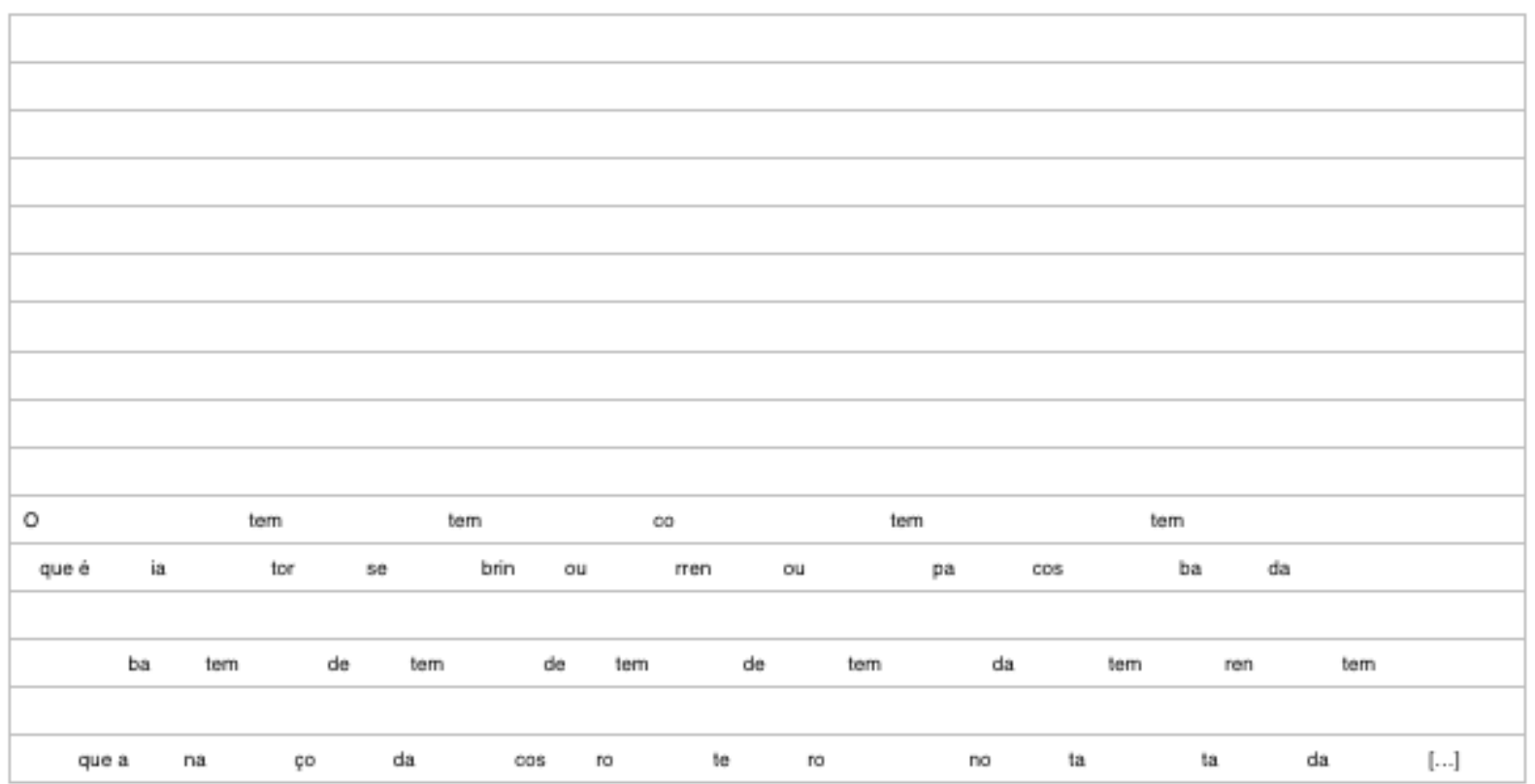


O terceiro é a famosa Garota de Ipanema de Tom Jobim. Temas melódicos reincidentes e letras que listem atributos positivos também não faltam aqui. A letra descreve a contemplação de um corpo e movimentos femininos que reúnem características altamente atrativas para o observador. A força de materialização de uma ideia, bem como a criação de uma relação entre ideia e estímulos físicos foi tão bem sucedida nessa canção que, ao longo de décadas ela alimentou (feliz ou infelizmente) representações da mulher brasileira e do próprio Brasil. Em pleno 2016, a canção foi usada na abertura dos jogos Olímpicos para tematizar o país, encarnado nas qualidades sensuais do corpo feminino. Trata-se daquilo que Tatit designou como iconização: «as formações icônicas são unidades de sentido indecomponíveis que reclamam uma captação em bloco pelos órgãos sensoriais» (2012, p.167). Garota de Ipanema sedimentou-se ao longo de décadas como o ícone por excelência da brasilidade, tendo a sensualidade feminina como uma de suas principais características. Praia, samba, carnaval e corpos femininos atrativos ainda são clichês que resumem o Brasil para um certo público estrangeiro. Quem transitou pela avenida Atlântica do Rio de Janeiro nos tempos em que a boate (prostíbulo) Help era um dos grandes «atrativos turísticos» da cidade pôde ver a força e as consequências desse clichê. Mas, voltando às características formais da canção, letra e melodia constroem um elo tão persuasivo que a tematização erigiu um ícone da brasilidade:

Garota de Ipanema, Tom Jobim (TATIT, 2004, p.186) 


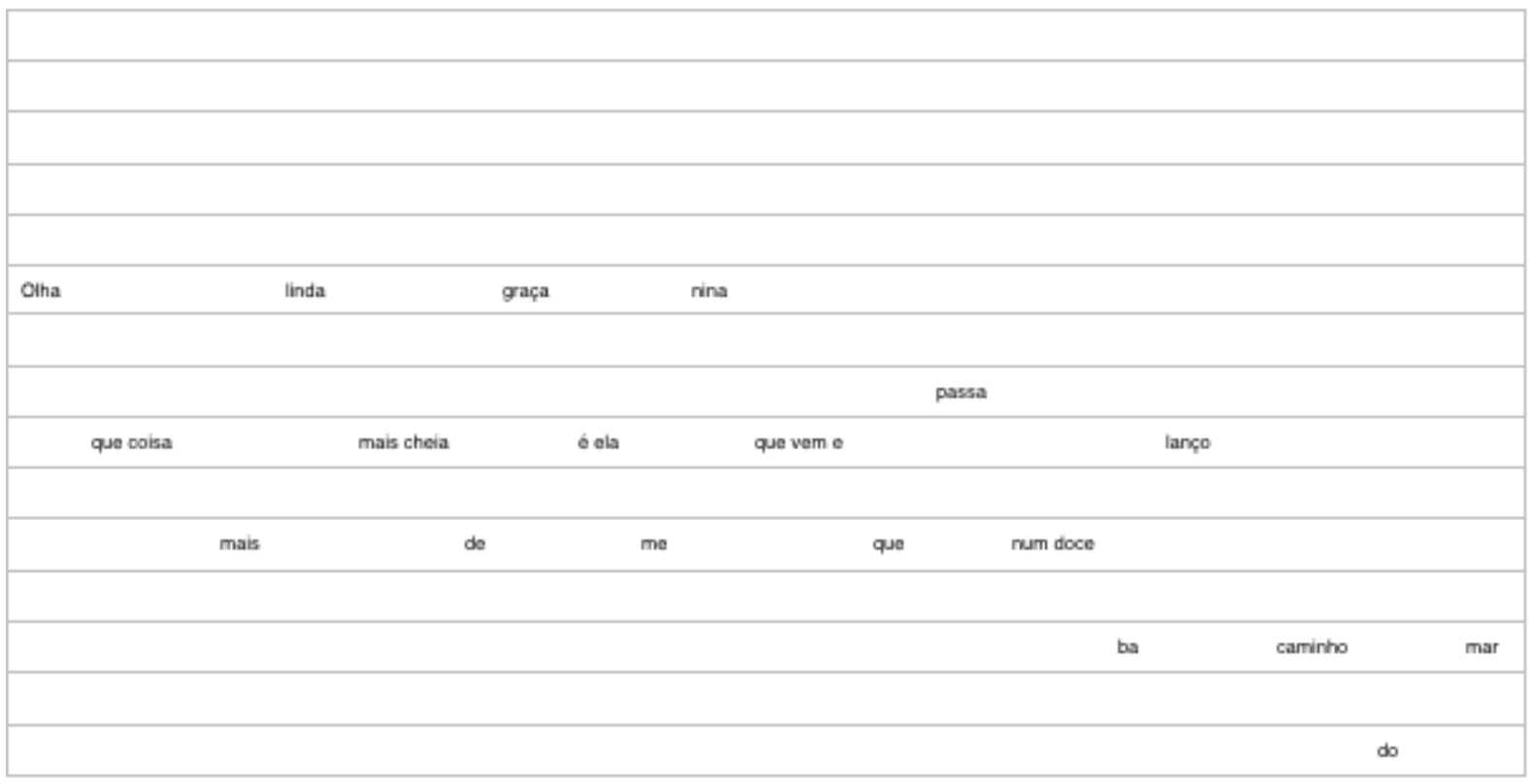

É importante reter da tematização a homologia entre forma de expressão e forma de conteúdo: ao mesmo tempo que a melodia constrói temas que se reiteram, a noção de alteridade no plano do conteúdo também permanece em grande medida anulada. Nas letras, tende a não haver distância entre sujeito e objeto de valor, quase não há percurso de busca, mas sim a repetição e celebração de unidades.

\subsection{Passionalização}

A persuasão passional, conforme já aludimos, se dá quando a costura entre o componente melódico e linguístico valoriza a duração das notas e das vogais, criando curvas melódicas distendidas no campo da tessitura ${ }^{62}$. Essa forma de expressão é propícia à inserção de estados passionais na canção, que persuadem o ouvinte não pelo envolvimento corporal, mas pela cumplicidade com os estados emocionais retratados. A característica principal desses estados passionais pode ser equacionada com aquilo que a semiótica chama de termo complexo, o termo que articula dois elementos polares ${ }^{63}$. No caso em questão, trata-se do termo junção, que articula a conjunção e a disjunção. Conjunção é quando o sujeito está em posse do seu objeto de valor (ou, o que dá na mesma, com o valor do objeto), seja ele a pessoa amada, o objetivo almejado, seja lá o que for; conjunção é quando o sujeito está em posse daquilo que lhe proporciona estados eufóricos. Disjunção é o contrário disso, é a distância, é a separação, é a cisão em relação ao objeto, e a disforia resultante disso. As

\footnotetext{
62 Tessitura é o campo das alturas, da nota mais grave à nota mais aguda, que uma peça musical abarca.
}

${ }^{63}$ Voltaremos a isso no item 4. 
canções passionais geralmente se caracterizam por retratar um estado de disjunção e a busca ou desejo por um novo estado de conjunção ${ }^{64}$, ao passo que as longas curvas melódicas e o passeio pelo campo da tessitura também configuram, no plano da expressão, um itinerário de busca ${ }^{65}$.

Segundo a semiótica, o estado da paixão surge como corte passivo no interior de uma narrativa, quando o sujeito, por algum motivo, está inabilitado a agir:

Em primeiro lugar, todo estado juntivo e toda disposição emocional podem ser enfocados como um corte no percurso narrativo traçado (com maior ou menor clareza) pelo texto. As narrativas são ações (ou "fazeres") que fundam as paixões (ou “seres”), "Paixão“, do latim passione ('ato de suportar, sofrer'), representa exatamente um corte passivo no interior de um processo ativo de narratividade. Um estado passional, portanto, pressupõe uma ação anterior - na qual o sujeito passional foi o sujeito passivo (que sofreu a ação) - causadora deste estado e, às vezes, constitui um ponto de efervescência desencadeador de novas ações. (TATIT, 1986, p.28)

A capacidade ou incapacidade para agir dentro de simulacros textuais é analisada pela semiótica por meio do processo de modalização (TATIT, 1986). Ou seja, é pela atribuição da capacidade de querer, dever, saber e poder; ou ao contrário, não querer, não dever etc. que o enunciador distribui os papéis exercidos dentro de um programa narrativo. É isso que define, segundo a semiótica, qual papel será exercido pela personagem. Mas o termo personagem é aqui insuficiente, e, portanto, substituído por actante, o qual recobre não apenas seres humanos, mas também animais, coisas ou conceitos ${ }^{66}$. Actante é, assim, toda unidade do texto que faz ou sofre um ato. Por exemplo, na frase: «vamos sentar-nos no sofá?» podemos distinguir três actantes: o interlocutor que faz a pergunta, o interlocutário presumido a quem ele se dirige, e o sofá. Os actantes interlocutor e interlocutário são sujeitos pois que dotados das modalidades poder (sentar-se ou não), assim como do saber fazê-lo e mesmo do querer ou não fazê-lo. O sofá, por sua vez, é um actante passivo, um objeto. Mas, se, ao longo da narrativa, o enunciador lhe atribuir capacidades modais (um sofá que tem o

\footnotetext{
${ }^{64}$ «A forma sintética de narrativa se traduz, portanto, no núcleo passional, que é uma espécie de centro psíquico onde se acumulam os estados resultantes de operações transformadoras. Trata-se de um lugar em que o sujeito sente a tensão de seu estado disjuntivo, vivendo paixões como tristeza, solidão, ciúme, esperança, frustração, ódio etc. Sendo proveniente de narrativas anteriores e, quase sempre, gerando novas ações, o estado de paixão pode ser visto como um centro que contém tais narrativas em forma condensada.» (TATIT, 2012, p.36)

${ }^{65}$ Nota-se que o componente linguístico não é o conteúdo, e o componente musical não é a forma. Ambos os componentes, sonoro e linguístico, possuem uma forma de expressão e uma forma de conteúdo.

${ }^{66}$ Greimas, A. J.; Courtès, J. Dicionário de semiótica. 2. ed. São Paulo: Contexto, 2011, p. 12.
} 
saber e o poder de falar e mover-se por vontade própria, dotado de um querer realizar determinadas ações), então o actante sofá poderá assumir outros papéis no programa narrativo, como o de herói ou anti-herói. Voltando ao estado passional, ele apresenta-se então como um corte na narrativa onde um sujeito, em decorrência de uma transformação anterior, está incapacitado de agir por causa da perda de uma ou mais modalidades. No mais das vezes, trata-se de um sujeito que quer estar em conjunção com o objeto de valor, mas não pode e sabe não poder estar em conjunção.

Um exemplo da tensão passional em sua plenitude é Nervos de Aço de Lupicínio Rodrigues, onde o estado passional é deflagrado pelo querer estar em conjunção, mas deparar-se com a sua impossibilidade:

\author{
Você sabe o que é ter um amor \\ Meu Senhor? \\ Ter loucura por uma mulher \\ E depois encontrar esse amor \\ Meu senhor \\ Nos braços de outro qualquer
}

Observe-se que as curvas melódicas distendem-se e ocupam um campo muito mais amplo de tessitura, sobretudo nos momentos em que a letra aborda a separação e os sentimentos disfóricos:

Nervos de Aço, Lupcinio Rodrigues (TATIT, 2012, p.130) 


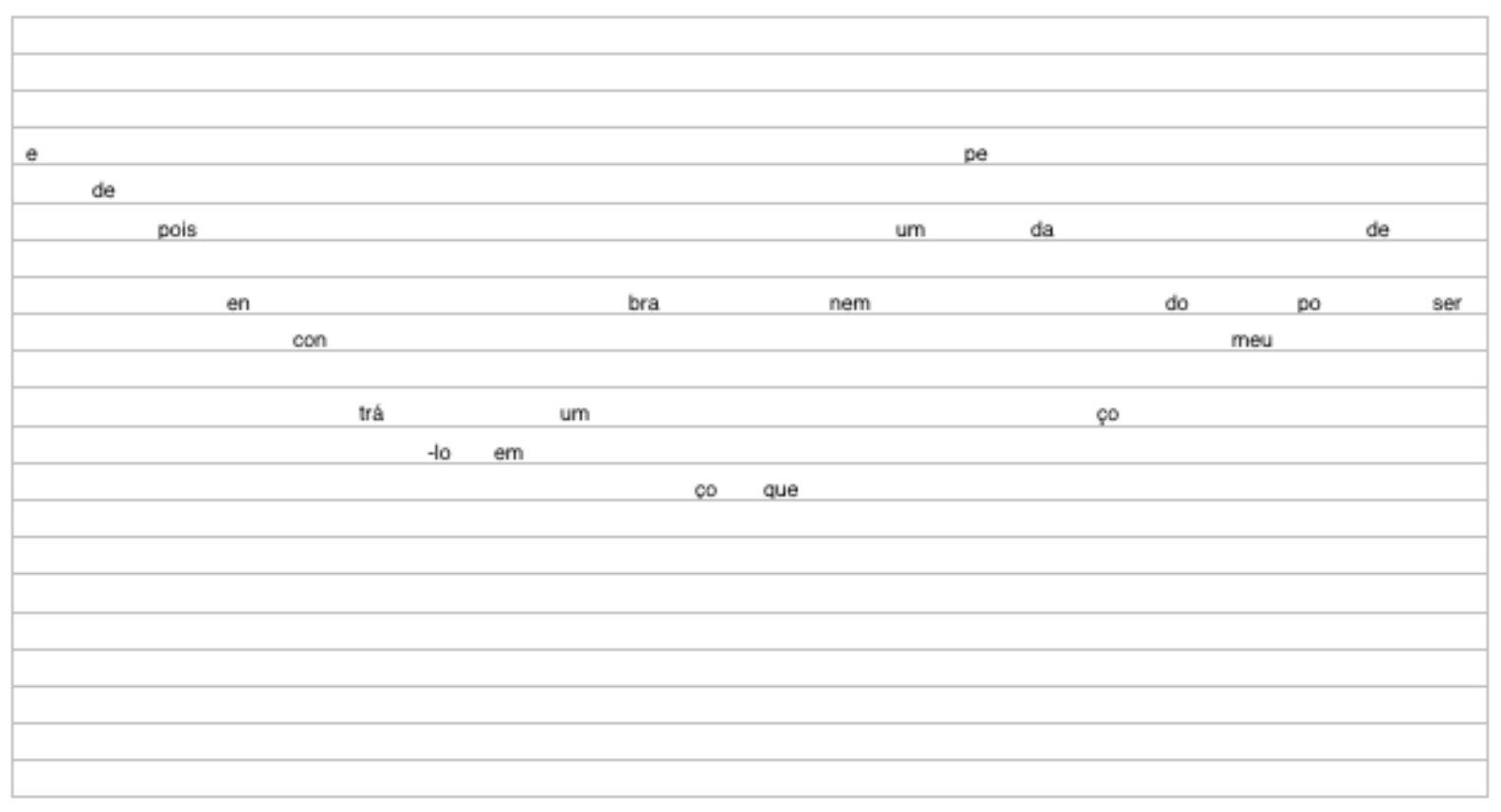

Pensando a homologia entre forma da expressão e forma do conteúdo, a passionalização ocorre quando a tensão (física) da emissão vocal de uma nota aguda ressoa na representação de tensões (psíquicas) do estado de paixão. Analisando as curvas melódicas, observa-se que a emissão de notas agudas prolongadas geralmente coincide com o auge da tensão da perda afetiva que desencadeia processos passionais. No entanto, não se deve acreditar que a relação entre forma da expressão e forma do conteúdo seja mecânica. ${ }^{67}$ Andamento lento e sustentações vocálicas podem ser usadas para exprimir conteúdos eufóricos, assim como o ritmo marcado pode ser recoberto por letras que expressam conteúdos disfóricos ${ }^{68}$. Assim podemos resumir a relação entre melodia e letra na tematização e na passionalização:

O texto modalizado pelo /fazer/ retrata ações ou qualificações capazes de deflagrar ações e persuasões. Possui, em geral, um fundo eufórico, reflexo da conjunção com os valores que vêm enumerados de acordo com a proposta de cada canção. A melodia é essencialmente marcada por acentos sobre pontos regulares de pulsação, emitindo sinais que repercutem na superfície de nosso corpo [...] O texto modalizado pelo /ser/ retrata estados de paixão decorrentes de ações narrativas anteriores. Seu enfoque principal é geralmente nos sentimentos ocasionados pelo movimento de disjunção e conjunção afetivas. A mesma modalidade que gera no texto esse quadro de passividade imprime na melodia um caráter de desaceleração

\footnotetext{
${ }^{67}$ Voltaremos a esse ponto no próximo capítulo

${ }^{68}$ Esse é exatamente o caso do baião de Luiz Gonzaga.
} 
do andamento, de ampliação das durações e frequências, de valorização das pausas e de neutralização parcial dos ataques e dos acentos [...] A tensão passional é expressa normalmente por picos e sustentação de notas agudas que representam as paixões disfóricas, ligadas à disjunção com o objeto de desejo. (TATIT, 2012, p. 150)

A tematização festeja encontro, ao passo que a passionalização representa a busca. $\mathrm{Ou}$ seja, os estados eufóricos e disfóricos, de conjunção ou disjunção, denotam o posicionamento do sujeito em relação ao objeto, se ele está próximo ou distante, se há uma relação de identidade ou alteridade entre eles. Podemos observar isso no plano da expressão. Ao ouvirmos uma melodia, identificamos os seus temas por eles serem, ao mesmo tempo, um pouco do que já foi, e um pouco do que será. Logo após as frases iniciais de uma peça musical, nas quais o tema é apresentado, a repetição dos elementos anteriores nos traz a sensação de coesão, de identidade daquilo que está sendo dito agora com aquilo que já foi dito antes. No entanto, a entrada de novos elementos rítmicos e melódicos nos trazem a sensação de evolução, de caminho, de progressão na melodia. Se tivéssemos apenas identidades e repetições, teríamos a sensação de que nada está acontecendo, de que a música não está indo a lugar nenhum. Se temos apenas diferenças, seria difícil captar a coesão da obra, qual «assunto» está sendo trabalhado. A mescla de involução/evolução, repetição/diferença, identidade/alteridade é o jogo, o vai e vem que faz das obras algo interessante, instigante, lúdico. Contudo, há peças nas quais predomina a repetição, a identidade; e outras nas quais predomina a alteridade: no caso das canções, as temáticas e as passionais. No plano do conteúdo, a identidade melódica traduz-se em celebração do encontro do sujeito com o objeto. Quase não há alteração melódica e itinerário de busca, pois o estado conjuntivo predomina sobre o que pode haver de disjunção. Por sua vez, o alongamento das durações dificulta a formação de temas, a melodia percorre lentamente suas notas em progressões gradativas, alternadas com saltos intervalares. No plano do conteúdo, o sujeito das canções passionais está ao mesmo tempo em disjunção e conjunção com o objeto, ele necessita do outro para recompor o que está fraturado: o outro está afastado, mas o desejo de conjunção com esse outro está presente.

Em suma, tematização e passionalização são duas formas resultantes da união entre melodia e letra, que tanto no plano da expressão quanto no plano do conteúdo, fazem com que as canções despertem determinados sentimentos e sentidos nos ouvintes. Poderíamos representar essas duas tendências num eixo horizontal, que vai da desaceleração à aceleração do andamento, da tendência à passionalização e à tematização. No entanto, esse é apenas um 
dos eixos de tendências que compõe as canções. Discutiremos a seguir outras tendências daquilo que poderíamos representar como o eixo vertical desse campo de tendências.

\subsection{Figurativização}

A terceira forma de persuasão advém do reconhecimento, por trás da voz que canta, da voz que fala na canção. A figurativização designa as formas de ajustar letra e melodia de modo a dar a impressão de que a linha melódica poderia ser uma inflexão entoativa da fala cotidiana, ou seja, a produção da fala no canto. Essa forma de persuasão configura-se como uma espécie de ponto neutro entre passionalização e tematização: nem lenta, nem acelerada, a costura das sílabas à melodia ocorre de modo a reproduzir a fala cotidiana na canção, a dar a impressão de naturalidade no modo de falar e de cantar. $\mathrm{O}$ desenho da curva melódica não tende nem à configuração de temas, nem a curvas distendidas pelo campo da tessitura, mas sim a uma pequena variação de graus próximos, recuperando algo da instabilidade da fala na forma da canção.

País Tropical, Jorge Ben (TATIT, 2012, p.214)

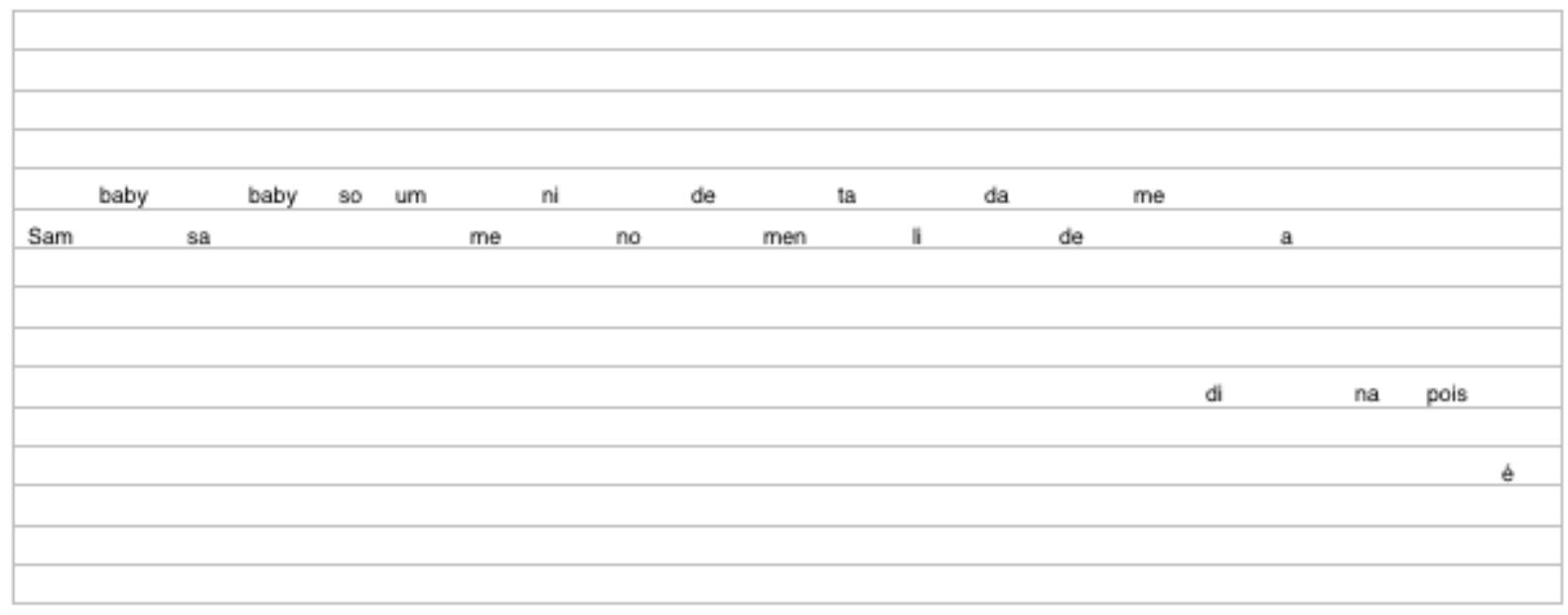

Transcrevemos acima um trecho de País Tropical de Jorge Ben Jor em que, ao lado das configurações temáticas do refrão, o cancionista faz uso da entoação instável para caracterizar seu personagem: uma figura sem qualidades excepcionais, mediano, comum, cotidiano, como a própria entoação usada para realizar a descrição.

A figurativização, assim como as outras formas de unir melodia e letra, é uma tendência que está sempre presente nas canções. Ela é em grande medida responsável pelo 
efeito de «verdade» ${ }^{69}$ no modo de entoar as melodias, pela impressão de que $o$ que está sendo dito na canção é compatível com o como está sendo dito, de que aquela frase poderia ser dita daquela maneira numa situação da vida cotidiana. É justamente este um dos principais recursos persuasivos da canção, de que a voz que canta não é apenas um instrumento emitindo sons, mas uma voz que fala, que nos diz alguma coisa de forma sedutora e convincente. Ao ouvir uma canção, somos frequentemente tomados pela ilusão de que ali está alguém que se dirige a nós, uma voz que nos quer dizer alguma coisa.

Conforme já apontamos, o reconhecimento da entoação por trás da voz que canta foi o passo fundamental de Luiz Tatit no reconhecimento da canção como um artesanato específico, que não é nem música, nem poesia, nem mesmo poesia musicada. Ouvindo o repertório do samba nas primeiras décadas de gravação do Brasil, Tatit viu na prática dos cancionistas uma "reciclagem" da fala cotidiana, a invenção de contornos melódicos que não imitam a fala cotidiana, mas criam modos plausíveis de dizer. A figurativização, enquanto ponto neutro e ancoragem das outras formas de costura entre letra e melodia, é a arte de criar contornos melódicos verossímeis com a fala cotidiana, reforçando a ilusão de que, na canção, a voz que canta é também uma voz que fala, uma voz que tem algo a dizer, que se dirige ao ouvinte diretamente, imediatamente, às vezes sem mesmo a mediação da compreensão racional do conteúdo, agindo diretamente sobre o corpo de quem ouve.

\subsection{Musicalização}

Contudo, na canção, ao lado da força entoativa, estão também sempre presentes recursos que servem para estabilizar a entoação com parâmetros musicais, ou seja, sempre há certa dose de musicalização. A fala cotidiana é, por natureza, instável. Nela, não há parâmetros de estabilização de altura, duração e andamento. Aliás, é raro que a mesma frase seja pronunciada duas vezes exatamente do mesmo modo, com o mesmo «envelope» sonoro. A canção, ainda que aproveite as direções melódicas sugeridas pela entoação da fala cotidiana, não pode prescindir de recursos musicais de estabilização: a estabilização das alturas, das durações, do andamento e do uso da tessitura (TATIT, 2016, p. 101). Porém, ao seguir a tendência da musicalização, a melodia cancional pode distanciar-se cada vez mais da "voz que fala" no canto, acabando por fazer uso da voz como se ela fosse apenas mais um instrumento musical. Essa é a forma com a qual a música erudita costuma trabalhar a voz. Aqui não há tanto a preocupação de construir um "modo de dizer" compatível entre forma e conteúdo, de que haja verossimilhança entre o que está sendo dito e o como está

\footnotetext{
${ }^{69}$ Voltaremos a essa questão no item Ilusão Enunciativa.
} 
sendo dito. Sobretudo na ópera, o importante é que a voz soe como um instrumento e se acomode na música, pois esta é, nesse caso, a linguagem artística em foco.

Isso nos traz ao seguinte ponto: ao juntar melodia e letra, o cancionista está aproximando duas linguagens distintas. Já vimos como as curvas da entoação evocam sentidos nos ouvintes pelo uso dos tonemas (terminação sonora das frases). A descendência ou a não ascendência do som na inflexão terminativa da frase é usada para transmitir a noção de finalização. A ascendência ou não-descendência é usada para transmitir a noção de prossecução ou pergunta. A suspensão, não-ascendência e não-descendência transmite a sensação de algo inacabado. Mas os recursos propriamente musicais também evocam uma dinâmica de conjunção e disjunção, identidade e alteridade, tensão e repouso; o que Tatit chama de tensividade. A tensividade musical ocorre, em grande medida, por conta do uso das consonâncias e dissonâncias como forma de estruturar os materiais e as formas musicais. O trabalho de Max Weber sobre os fundamentos racionais e sociológicos da música procura abordar justamente as formas da música ocidental administrar a dissonância. Desse esforço surgiu o sistema tonal, configurando uma estrutura musical que subjaz às produções musicais, da Renascença ao século XX, e, mesmo depois de ter sido parcialmente abandonado na música erudita, continua a ser a linguagem dentro da qual a música popular é pensada e composta em praticamente todas as suas vertentes. O sistema tonal opera um recorte do espectro sonoro, determinando distâncias entre as notas musicais (intervalos). Ao fazê-lo, ele estabelece a primeira nota da escala, a tônica, como um centro gravitacional, um polo de atração ao redor do qual se posicionam as demais notas, e a partir do qual elas adquirem suas funções musicais. A tensividade musical surge então do jogo de aproximação e afastamento das notas e acordes com relação à tônica, o percurso melódico e harmônico para o afastamento e a volta à tônica, criando sensações de tensão e relaxamento, disforia e euforia.

Na canção popular brasileira, a Bossa Nova talvez seja o grande exemplo de canções onde predomina a musicalização (TATIT, 2016). Pensemos nas canções de Tom Jobim, que não por acaso seguiu a tendência da musicalização, pois que ele é um dos poucos cancionistas brasileiros consagrados com uma formação musical erudita. Valendo-se das progressões harmônicas do jazz, Jobim aproveitou as possibilidades de modalização da cadência harmônica pelos acordes dissonantes para abrir novos caminhos para a melodia (TATIT, 2012. p. 163). Enquanto a "batida" do violão caracterizava sutilmente o ritmo do samba, a melodia enveredava por caminhos pouco usuais na canção brasileira, guiada pelas progressões harmônicas. Assim, a melodia era guiada muito mais por um pensamento 
musical do que pelo manejo intuitivo da entoação. Esse modo de pensar a melodia teve consequências também para o modo de criar os versos, pois a voz, afastando-se da "voz que fala" tende também a apontar menos para a carga semântica do que está sendo dito do que para a sua própria sonoridade enquanto instrumento musical. Ou seja, a figurativização e a musicalização são duas tendências no modo de trabalhar a voz, a primeira apontando para a "voz que fala", a voz como instrumento de comunicação de conteúdos. Já a segunda aponta para a "voz que canta", e tende a esvaziar os conteúdos semânticos das palavras para valorizar o som, o timbre instrumental que ressoa pela voz. Na Bossa Nova, as canções evitam letras de forte carga semântica, chegando mesmo a temas infantilizados, numa estratégia que Tatit chama de dessemantização:

\footnotetext{
Os versos ideais eram aqueles que anunciavam a presença do cantor, recortavam as unidades entoativas, mas não se deixavam levar pelo "peso" do conteúdo. Para tanto, além da adoção do registro quase infantil ( $O$ barquinho, Trem de Ferro, Presente de Natal, O Pato, Lobo Bobo) e dos comentários sobre a própria música (Samba da Minha Terra, Samba de Uma Nota Só, Bim Bom), os autores recorriam aos temas gerais pouco conflitivos (Brigas, Nunca Mais) que, de certo modo, se anulavam como conteúdo, orientando a atenção do ouvinte para o encaixe fonético das palavras na levada do samba. (2016, p. 111)
}

Nesse sentido, o antípoda da Bossa Nova é certamente o Rap, que praticamente exclui a voz que canta da voz que fala, realçando ao máximo o conteúdo semântico do que está sendo dito. Também no Rap há um arranjo entre forma de expressão e forma do conteúdo, pois que, ao quase eliminar o uso das alturas melódicas e concentrar-se na formulação de um modo de dizer, o Rap cria as condições para a exposição de letras de denúncia social e relatos de vida. Isso quer dizer que também nesse caso há uma construção estética da verossimilhança entre o que está sendo dito e o como está sendo dito, uma estratégia de persuasão, de construção da "verdade" da mensagem cancional. Contudo, o Rap também nunca abandonou alguns padrões de estabilização musical da entoação, mantendo-se dentro do campo de tendências da canção: "O radicalismo do relato narrativo cru sobre uma estrutura rítmica (rhythm and poetry), adequado às contestações sociais, sempre se apoiou em riffs percussivos, em ostinatos do contrabaixo e, na maior parte dos casos, em refrãos bem caracterizados, como que já atenuando seu gesto inicial" (TATIT, 2016, p.48).

Assim sendo, naquilo que poderíamos representar como um eixo vertical das tendências da canção, temos de um lado a figurativização (ou oralização) e de outro a 
musicalização. A tendência à figurativização configura-se como a representação da voz que fala na canção, o que propicia também o realce do conteúdo semântico das palavras. Já a tendência da musicalização, ao se afastar da voz que fala, pode proporcionar a dessemantização do conteúdo, mas realça o papel da voz como instrumento musical, permitindo que ela explore caminhos melódicos independentes da entoação da fala.

Musicalização

concentração

temática

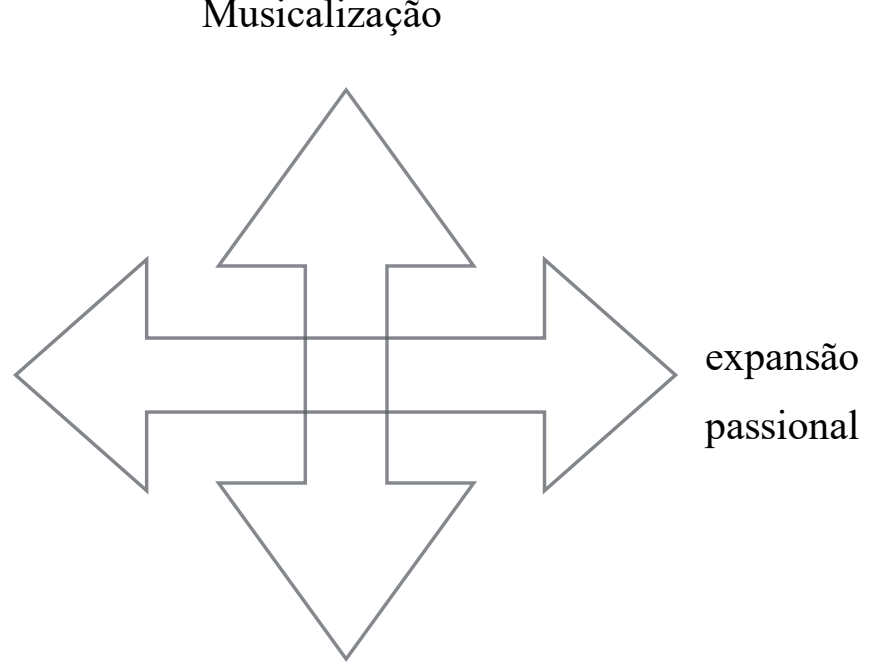

Campo de Oscilação Cancional ${ }^{70}$

Figurativização

Tipos ideais de curvas melódicas:

\section{Curva temática:}

Curvas que delineiam temas melódicos bem estruturados, que tendem a repetir-se insistentemente. Tendência de afirmar um movimento concêntrico, eliminando a sensação de percurso ou itinerário de busca.

\section{Curva passional:}

Curvas de arcos longos e distendidos, tendendo a perfazer um percurso por vezes imprevisível. Tende a afirmar um itinerário de busca, um percurso ao longo do campo da tessitura, enfraquecendo a sensação de repetição e identidade de temas melódicos.

\section{Curva figurativa:}

\footnotetext{
${ }^{70}$ Figura extraída de TATIT, 2016, p.166.
} 
Curvas de arcos curtos, ocupam um espaço estreito do campo da tessitura, que tendem a não configurar nem temas melódicos bem estruturados nem itinerários de busca; espécie de ponto neutro da tensividade entoativa.

\subsection{A articulação das quatro tendências}

Conforme discutimos até aqui, a gramática da canção constrói sentidos sobretudo nas formas de unir melodia e letra. No eixo que chamamos de horizontal, no qual o andamento musical varia do lento ao rápido, ao passo que as sílabas se estendem ou se contraem, temos as formas de passionalização e tematização. Nesta, a proximidade dos elementos denota estados conjuntivos e eufóricos, ao passo que o alongamento denota a espera, o desejo e o itinerário de busca. Mas acontece que cada uma dessas formas acaba por dar espaço, dentro de uma mesma canção, à forma contrária. Por exemplo, em uma canção temática, é raro que permaneça o tempo todo a repetição dos mesmos temas. A parte mais eufórica e repetitiva delas geralmente é o refrão. Mas quase não há canção que seja só refrão, o material melódico se expande configurando outras partes, assim como a letra também explora outros conteúdos, nem que seja para voltar ao refrão com um gosto renovado de conjunção e euforia. Ou seja, mesmo as canções temáticas convocam as formas mais próximas da passionalização. $\mathrm{O}$ contrário também ocorre: uma canção passional também faz uso de graus imediatos e gradações melódicas, geralmente como forma de preparar a entrada de saltos melódicos e longas sustentações vocálicas, que caracterizam as partes principais desse tipo de canção. Em suma, as características principais da tematização significam uma minimização das características da passionalização, e vice-versa. Mas, para dar dinâmica às canções, é comum que o cancionista alterne, nas partes que as compõem, recursos temáticos e passionais. Conforme formulou Luis Tatit:

No entanto, o pleno funcionamento da linguagem cancional se dá evitando saturação ou extinção das duas modalidades melódicas. Há canções que demonstram isso restabelecendo, por exemplo, um perfil passional no interior de uma configuração claramente temática. É o caso da melodia da segunda parte de Garota de Ipanema ("Ah, como estou tão sozinho... ") ou de Alegria, Alegria ("E o sol nas bancas de revista..."). Mas o entrosamento entre os dois modelos é mais profundo. Tanto as melodias temáticas quanto as passionais trazem recursos complementares que, por um lado, atenuam as suas próprias características centrais, e, por outro, convocam traços do modelo oposto. (TATIT, 2016, p. 58, grifos do autor) 
Naquilo que estamos chamando de eixo vertical, na polarização entre figurativização e musicalização, também é comum que o cancionista «dose» a quantidade de cada um desses recursos, evitando a saturação de cada uma das formas. De um lado, evita que o uso dos recursos musicais desvirtue completamente o modo de dizer, apague completamente a voz que fala por trás da voz que canta. Por outro, a completa ausência de recursos musicais desvirtuaria a canção enquanto tal, por apresentar a fala crua no lugar do canto. Mais uma vez, assim resume Luiz Tatit:

Atenuar a musicalização é reconhecer que as melodias cantadas comportam figuras entoativas (modos de dizer) que precisam ser reveladas por suas letras. Atenuar a matéria bruta da fala é reconhecer que as mensagens linguísticas poderão ser não apenas entendidas pelos ouvintes, mas também fixadas com recursos musicais que favorecem a reprodução de suas frases pelos seguidores e aficionados do gênero. Atenuar a tematização é injetar alteridade na identidade melódica por meio de pequenas e significativas variações da linha cantada. Atenuar a passionalização é graduar os intervalos melódicos e introduzir alguma recorrência nos movimentos verticais (grave/agudo) do canto para, justamente, injetar identidade no domínio da alteridade, marcado por grandes inflexões vocais. (TATIT, 2016, p.121)

Em suma, a linguagem da canção é exercida no interior de um campo de tendências, onde os compositores atuam no sentido de evitar pontos extremos, no sentido de não permanecer por muito tempo nos limites de uma tendência, para não correr o risco de desequilibrar a dinâmica e a coerência de suas obras. Tanto uma obra que permanecesse apenas na conjunção e euforia, quanto uma que permanecesse apenas na disjunção e disforia correriam o risco de não engajar o destinatário nos conteúdos representados.

\section{Ilusão enunciativa}

Vimos até aqui quais são as formas de unir melodia e letra, analisando como proporcionam a construção de tipos de canção. É hora de darmos um passo atrás e questionar o que é que está sendo representado quando um cancionista faz essas costuras entre melodia e letra ao compor uma canção. Quando se fala de representação ${ }^{71}$ na arte, é pressuposto que

${ }^{71}$ Poder-se-ia argumentar aqui que a música é uma forma de arte não-representativa. Ou seja, que não existe uma "coisa" ou modelo que corresponda, no universo extramusical, àquilo que está sendo expresso nas obras musicais. Há uma famosa citação extraída de Schopenhauer, segundo a qual a música seria a cópia de um modelo que não pode ser traduzido. Essas afirmações são pertinentes quando se trata da música instrumental. Certamente não é possível afirmar inequivocamente o que uma sequência de notas musicais "diz". Mas tudo 
haja alguma coisa, ainda que seja o conceito mais abstrato, sendo re-apresentado na obra. Aliás, não apenas na arte, mas em todas as formas de texto, verbais e não-verbais, nós estamos lidando com signos. Por outras palavras, todas as formas de expressão artística supõem que nós sejamos capazes de ver mais do que tinta sobre uma tela, mais do que luzes projetadas numa superfície, mais do que pedras cortadas em diferentes formas, mais do que corpos humanos em um palco. Todas essas modalidades supõem que sejamos capazes de distinguir alguma forma de sentido na pintura, no cinema, na escultura ou no teatro. Contudo, nas formas tradicionais das artes visuais e performáticas é relativamente mais fácil relacionar a representação da obra com o (conceito do) objeto no mundo real. Na pintura renascentista, por exemplo, Michael Baxandall ${ }^{72}$ mostra que, para além dos significados simbólicos, grande parte do desafio da pintura era então representar, com o máximo de efeito de verdade, um objeto tridimensional em duas dimensões. Era buscada a ilusão de que um objeto real estava ali, diante dos olhos. Mas qual é a ilusão de realidade que se pretende alcançar numa canção? O que ela estaria tentando representar?

A resposta é a ilusão enunciativa, a ilusão de que se está diante de uma situação de comunicação, de que alguém está dizendo algo para alguém (TATIT, 1986). A voz que fala no interior da voz que canta traz para o ouvinte a impressão de que ele está diante de uma enunciação, de que o personagem da canção é uma pessoa, geralmente associada à imagem de quem canta, que fala aqui e agora para o ouvinte. Toda canção prevê a performance de um cantor (nenhuma delas é composta para circular como apenas um texto escrito), a qual como que reanima os conteúdos da letra, dando a ilusão de que os fatos e sentimentos retratados estão sendo revividos no tempo da performance. Os sentimentos eufóricos e disfóricos que surgem da união entre melodia e letra realçam ainda mais o comprometimento do cantor-emissor com o texto que transmite, uma vez que a tarefa do intérprete é justamente reanimar, reatualizar os conteúdos inscritos na obra da melhor forma possível (aquilo que Goffman chama de realização dramática, que será discutida no próximo capítulo: a necessidade de reafirmar dramaticamente - no sentido teatral do termo - a atividade executada). Todos esses fatores alimentam a ilusão de que o intérprete fala de si quando canta, de que a personagem da canção se confunde com a sua pessoa real (TATIT, 2016, p. 130). A emissão da voz pressupõe a presença de um corpo físico, e os sons que ela produz acusam tensões e relaxamentos dos músculos que produzem a voz. Como formulado por

muda quando estamos lidando com a união de letra e melodia. O componente linguístico associa aos sons um conteúdo semântico determinado.

${ }^{72}$ Michael Baxandall. L'oeil du Quattrocento: l'usage de la peinture dans l'Italie de la Renaissance. Paris: Gallimard, 1985. 
Roland Barthes em O grão da voz, a voz traz diretamente ao ouvinte o corpo do intérprete, a presença de um som produzido em cavidades, músculos e membranas, recebido também fisicamente pelos ouvintes. A voz é uma comunicação direta entre corpos, muito antes de ser a transmissão de conteúdos semânticos. Ou seja, a voz promove uma comunicação carnal, e quando, na canção, essa comunicação vem revestida de palavras e tensões melódicas, os conteúdos transmitidos são literalmente encarnados pela voz do intérprete.

Daí resulta, novamente, a importância do "lastro" entoativo da canção, de que uma voz que fala seja reconhecível na voz que canta. A importância estética da figurativização advém de ela ser também uma estratégia de persuasão dos ouvintes ao fazê-los crer na "verdade" da enunciação, de que o intérprete pensa, sente e faz tudo aquilo que ele canta no aqui agora da canção. Mas é claro que as outras formas de persuasão, como discutimos acima, também entram em cena numa estratégia global de sedução do ouvinte.

Devemos também assinalar alguns recursos estritamente textuais de criação da ilusão enunciativa. Retomemos aqui os argumentos de Luiz Tatit em A canção: Eficácia e Encanto (1986). O autor chama de eficácia da canção o êxito da comunicação entre o destinador locutor (o alguém que canta) e o destinatário ouvinte. Quando essa comunicação é bemsucedida, o seu êxito consiste em fazer com que o destinatário deseje ouvir uma determinada canção $^{73}$. Quando a comunicação da canção é eficiente e persuasiva, o ouvinte é levado a aceitá-la, a identificar-se com ela, é levado a ouvi-la e reouvi-la (TATIT, 1986). Esse processo de persuasão é chamado de sobremodalização pela semiótica. Todos os «fazeres» pressupõem relações modais, designadas pelos verbos querer, dever, saber e poder (Idem). Na relação entre destinador locutor e destinatário ouvinte promovida pela canção, o saber fazer do destinador leva ao querer fazer do ouvinte, o qual, nesse caso, é ouvir. A competência do destinador consiste em despertar o querer do seu destinatário:

\footnotetext{
Todo enunciador dirige-se a um enunciatário tentando persuadi-lo daquilo que está sendo dito (ou escrito, desenhado, filmado, interpretado, composto etc.), o que o faz assumir necessariamente o papel de um destinador persuasivo (ou manipulador) e a conceber seu enunciatário como um destinatário de suas estratégias criativas e argumentativas. (TATIT, 2014, p. 298)
}

Um dos elementos fundadores do processo de sobremodalização na canção (como em qualquer outro texto) é a construção de simulacros de ações, paixões e modos de dizer: “o ouvinte depara, entre outras coisas, com uma ação simulada ('simulacro') onde alguém

\footnotetext{
${ }^{73}$ Voltaremos este ponto no próximo capítulo.
} 
diz (canta) alguma coisa (texto) de uma certa maneira (melodia)" (TATIT, 1986, p.6). A figurativização traz para a canção o simulacro do discurso oral, aproximando-a de uma situação cotidiana de comunicação. O texto da canção, por sua vez, traz consigo indicadores que simulam a situação de comunicação: "Quase sempre, a melodia com tendência entoativa acentuada recobre um texto repleto de indicadores ('deixis') a respeito do tempo, do espaço e dos actantes EU/TU implicados na comunicação" (1986, p. 8). Esses são recursos usados para presentificar o aqui agora da cena narrada no momento da enunciação musical.

Ao presentificar a cena, o destinador locutor também simula, muitas vezes, uma comunicação entre interlocutor e interlocutário, ou seja, de que a comunicação entre Eu e Tu construída na canção está ocorrendo também entre cantor e ouvinte, ou, pelo menos, que o «eu» actante construído no texto é ao mesmo tempo o «eu» do cantor. A sua figura sincretiza as posições dos dois sujeitos, vivificando a cena retratada.

O uso do diálogo na canção é uma das formas mais evidentes de presentificar uma situação de comunicação direta:

Sinal Fechado, Paulinho da Viola:

\author{
Olá, como vai? \\ Eu vou indo. E você, tudo bem? \\ Tudo bem, eu vou indo...
}

Mas não apenas a representação do diálogo entre dois personagens presentifica a cena. A simples menção de um $e u$ ou $t u / v o c e ̂$ já cria a ilusão de uma comunicação direta (veja-se logo adiante o conceito de debreagem):

Preciso dizer que te amo, Cazuza:

É que eu preciso dizer que eu te amo

Te ganhar ou perder sem engano

Eu preciso dizer que eu te amo tanto

Rosa, Orlando Silva:

Tu és, divina e graciosa, estátua majestosa do amor

Por Deus esculturada e formada com ardor

Outro importante elemento na construção de simulacros que presentificam as cenas são os deíticos, elementos linguísticos que servem para caracterizar uma situação de locução. 
Na canção, é frequente o aparecimento de deíticos vocativos, os quais, na linguagem oral, chamam, convocam o interlocutor para a situação de comunicação simulada.

Barbara, Chico Buarque

Bárbara, Bárbara

Nunca é tarde, nunca é demais

Nervos de Aço, Lupcínio Rodrigues

Você sabe o que é ter um amor

Meu Senhor?

Os deíticos imperativos também estabelecem uma comunicação direta entre o interlocutor e interlocutário da comunicação simulada no texto, a qual pode se estender para a comunicação principal entre cantor e ouvinte.

Pra não dizer que não falei das flores, Geraldo Vandré

Vem, vamos embora

Que esperar não é saber

Quem sabe faz a hora

Não espera acontecer

Não enche, Caetano Veloso

Me larga, não enche

Você não entende nada

E eu não vou te fazer entender

Me encara, de frente

É que você nunca quis ver

Não vai querer, nem vai ver

Beatriz, Chico Buarque

Olha

Será que ela é moça

Será que ela é triste

Será que é o contrário

Será que é pintura

$\mathrm{O}$ rosto da atriz 
Outros deíticos que aparecem com frequência são os espaciais e temporais, que fornecem ao destinatário indicações a respeito do tempo e espaço da cena retratada, permitindo-lhe reconstruir e situar-se na cena:

Negro Drama, Racionais MC's

\author{
Uma negra \\ E uma criança nos braços \\ Solitária na floresta \\ De concreto e aço
}

\title{
Diversões Eletrônicas, Arrigo Barnabé
}

\author{
Só você não viu \\ Mas ela entrou, entrou com tudo \\ Naquele antro, naquele antro sujo \\ Você nunca imaginou, mas eu vi \\ No luminoso estava escrito \\ Diversões eletrônicas \\ Era um balcão de bar de fórmica vermelha
}

Os deíticos são, portanto, elementos que ajudam a construir o simulacro textual de ações, sentimentos etc. Mas há um outro dispositivo mais geral e que os abarca os deíticos, por meio do qual o enunciador simula maior ou menor distância em relação ao texto, a debreagem. A debreagem enunciva - que se refere ao enunciado - é o dispositivo pelo qual o enunciador cria um efeito de distanciamento em relação ao texto, ao instaurar uma terceira pessoa, um outro tempo e espaço. É quando o simulacro textual se reporta a um "ele, lá, outrora". Já com a debreagem enunciativa, o enunciador constrói um "eu - aqui - agora" na narrativa, projetando-se no relato. Ambas as formas de debreagem servem a propósitos persuasivos, ora imprimindo objetividade pelo distanciamento, ora cumplicidade pela proximidade:

Ambos os efeitos são ficções que devem ser tomadas como estratégias persuasivas desenvolvidas pelo enunciador geral do texto. Fazendo uso da debreagem enunciativa, ele causa a impressão de objetividade, o que pode ser útil em alguns gêneros literários (como o épico), numa tese acadêmica ou na confecção da primeira página de um jornal diário. Atendo-se à debreagem enunciativa, o enunciador investe na impressão de subjetividade, o que pode favorecer outros 
gêneros literários (como o romântico), os textos de depoimento ou confidência e as manifestações líricas de modo geral. Todas essas estratégias têm como objetivo fazer com que as coisas ditas pareçam, de acordo com o contexto discursivo, verdadeiras. (TATIT, 2014, p. 196, grifos nossos)

Como exemplo podemos pensar nas letras de Construção e Eu te amo de Chico Buarque. Na primeira, o narrador onisciente e em terceira pessoa opera uma debreagem enunciva para construir um relato quase épico dos últimos momentos da vida de um trabalhador, de uma maneira e com uma riqueza de detalhes que apenas um narrador onisciente poderia fazer, afastando-se, portanto do relato. Na segunda, sendo uma canção de amor, o enunciador projeta-se no eu-aqui-agora da canção para dar credibilidade aos sentimentos que apenas uma parte afetivamente envolvida na cena poderia manifestar.

Portanto, deíticos e debreagens são recursos de construção de simulacros de situações de comunicação representadas nas canções. Claro que esses não são os únicos recursos na construção de simulacros, mas são elementos que ajudam na análise do modo de construção das cenas retratadas, bem como das estratégias de posicionamento do narrador em relação ao relato. Esses e outros elementos trabalham conjuntamente na persuasão do ouvinte a respeito da ilusão enunciativa.

O leitor cético certamente aventaria a questão de que nem todas as canções buscam a ilusão enunciativa, assim como outras formas artísticas se afastaram da intenção de ilusão de realidade. O teatro épico de Bertold Brecht, por exemplo, integra recursos que acusam a todo momento a falsidade da representação, que relembram o espectador a todo momento de que ele está no teatro, e que aquilo não passa de ficção. A intenção é promover uma recepção crítica da obra, dentro de um contexto global de retirar a plateia da passividade, não apenas estética como também política. A pintura, desde as vanguardas do início do século XX, abandonou (ao menos em parte) a busca pelo efeito de real na representação de objetos. No cinema, porém, já é mais raro encontrar filmes que procurem instigar no público a consciência da ilusão (os diretores da Nouvelle Vague são dos poucos que enveredaram por esse caminho). Na música popular brasileira, por sua vez, a explicitação da ilusão enunciativa restringe-se quase que apenas aos grupos que trabalham com o chiste: Premeditando o Breque, Língua de Trapo e Tom Zé são exemplos possíveis. Ainda assim, mesmo os artistas que acusam a ilusão que sustenta a representação o fazem como estratégia de persuasão do seu público a respeito da mensagem específica que desejam transmitir. Ou seja, a quebra da ilusão também é um recurso persuasivo. 


\section{Axiologia}

Vimos até aqui como a semiótica da canção de Luiz Tatit analisa a geração de sentido nas formas musicais. O autor sustenta que a semiótica é o estudo das estruturas de significação que subjazem aos textos verbais e não verbais (1997). O desafio, na busca dessas estruturas, é "extrair o valor sintáxico dos elementos semânticos” (2014, p.383), é explicitar a organização da forma do conteúdo. Devemos agora dar um passo adiante e ver como o autor se vale da teoria semiótica da geração do sentido. O nosso interesse de pesquisa reside no modo como a canção produz, a partir dos seus próprios recursos, representações (mais especificamente, as representações de modernidade nacional no álbum Clara Crocodilo de Arrigo Barnabé). Além disso, é também de nosso interesse o modo como os textos propõem uma avaliação valorativa daquilo que buscam representar: como os simulacros textuais erigem determinados conteúdos como algo atrativo ou repulsivo. Tatit defende que a canção, como as demais formas de texto verbais e não verbais, possui estruturas geradoras de sentido, e o que para nós é ainda mais instigante, que essas estruturas sempre atuam com atribuições valorativas: os simulacros textuais sempre distinguem o desejável do indesejável, o atraente do repulsivo.

Pensemos em uma canção, passional ou temática. Toda canção de sucesso atinge um número considerável de ouvintes, e algumas delas chegam mesmo a "marcar época", tornam-se sinônimos de um período da vida social em determinado lugar. No Brasil, é comum que se recorram às canções dos anos 1960 e 1970 para falar da ditadura militar, até mesmo como instrumento didático em sala de aula. Uma canção, pela união de melodia e letra, possui um razoável poder de sedução dos ouvintes, "é como se ela coletivizasse uma vivência" (2012, p.137), formulou Luiz Tatit. Vimos como a adequação do modo de dizer melódico com o conteúdo linguístico, a construção de simulacros e debreagens persuade o ouvinte, e que a própria dinâmica de construção da narrativa cria marcações valorativas.

A semiótica chama de axiologia a existência de um sistema de valores morais, lógicos, estéticos etc. em um determinado texto ${ }^{74}$. Entende-se que todo valor semântico é passível de receber um investimento de deixis (monstrativos) positivos ou negativos pela categoria fórica. Ou seja, todo conteúdo é passível de receber um investimento afetivo eufórico ou disfórico, atrativo ou repulsivo. Quando uma canção temática como Brasil Pandeiro exalta determinados valores como tipicamente brasileiros, ela institui também um ritual de celebração dos valores marcados como eufóricos, e o ouvinte persuadido pela

\footnotetext{
${ }^{74}$ Greimas, A. J.; Courtès, J. Dicionário de semiótica. 2. ed. São Paulo: Contexto, 2011, p. 37.
} 
canção tende a aceitar, ao menos durante o tempo da escuta, o sistema valorativo construído por ela.

Segundo Tatit (2001, p.63), a existência de valores no texto, marcada sob o aspecto fórico pelos termos euforia/disforia, corresponde a uma classificação profunda, axiológica, dos valores que o texto constrói como coletivos. Ou seja, para além dos valores desejados por determinados actantes no texto (o que a semiótica chama de ideologia), ele constrói também valores mais profundos, que surgem na forma de valores desejáveis (ou não) e objetos devidos (ou não) para uma comunidade. Para a semiótica, as informações a respeito do plano axiológico só podem ser fornecidas pelos recursos de construção do próprio texto, nos mecanismos de atração e repulsão apresentados nas relações entre sujeito e objeto. A busca permanente dos valores empreendida pelos actantes é uma indicação do modo de existência dos valores profundos e de seu investimento fórico.

Portanto, se toda comunicação é uma empresa de persuasão (TATIT, 2001, p.80), a semiótica mostra que os simulacros textuais possuem poder de persuadir o destinatário, também no sentido de colocar em circulação um índice axiológico, uma classificação dos valores desejáveis e indesejáveis. É interessante nesse sentido o esquema narrativo desenvolvido por Vladmir Propp, também chamado de esquema narrativo canônico. Esse esquema, desenvolvido a partir da análise de um corpus de contos folclóricos russos, estabelece que existem três etapas principais da narrativa: a manipulação (algo faz o sujeito engajar-se na busca dos valores), a ação propriamente dita e a sanção final. Nessa etapa final, quando, por exemplo, o herói é premiado e o vilão, castigado, é o momento por excelência de reafirmação da axiologia vigente no texto. Se o leitor, expectador, ouvinte etc. é envolvido pela história, vibra com o sucesso do herói e com a punição do vilão, ele de alguma forma foi persuadido pelo índice axiológico do texto. Podemos dizer então, que os textos, em última instância, comunicam princípios de classificação valorativa.

Como micro-universo semântico, a canção também, contém um índice axiológico e procura persuadir seu destinatário a respeito de quais conteúdos possuem valor eufórico e quais possuem valor disfórico. Sem a oscilação fórica, estaria comprometida a aproximação e a distância do sujeito com relação aos valores, e a própria possibilidade de construir narrativas. $\mathrm{O}$ envolvimento afetivo do sujeito aparece então como condição para a criação de metas, direções e sentidos. Observada sob essa perspectiva, a canção, como qualquer outro texto, não é um veículo neutro de comunicação. Ainda sendo um produto cultural que não visa a recepção intelectual, mas a afetiva do ouvinte, não deveria ser subestimado o 
poder persuasivo da canção em convencer seu destinatário a respeito do seu índice axiológico.

Os que consideramos os pontos principais da semiótica da canção de Luiz Tatit são esses. Conforme procuramos mostrar, o autor construiu um arcabouço consistente de análise da canção popular a partir de conceitos semióticos. Ainda mais por ter-se debruçado sobre o processo de constituição da canção popular brasileira, acreditamos que a obra de Luiz Tatit é um ponto obrigatório para aqueles que pretendem abordar a canção não apenas sob a perspectiva de produção, circulação e consumo, mas principalmente para aqueles que acreditam haver algum interesse em seu conteúdo propriamente dito.

Mas há também limites dessa teoria quando vista a partir de uma perspectiva sociológica. Esse limite mostra-se sobretudo quando Tatit define o fazer semiótico: "Este [o exercício de busca das categorias e articulações pressupostas] nos parece ser o verdadeiro fazer semiótico, na medida em que permite ao analista conjugar o emprego de conceitos já consagrados pela teoria com uma constante revisão de sua coerência e rendimento numa descrição específica" (2001, p.17). Ou seja, o trabalho do estudioso de semiótica consiste na constante aplicação de conceitos e na busca do aperfeiçoamento dos seus modelos de descrição do texto. Mas para o sociólogo, a análise textual, a leitura propriamente dita, embora seja, do nosso ponto de vista, parte fundamental e indispensável, é apenas uma parte. É preciso também ir além do texto e observar se e como os princípios de classificação postos em circulação pelos simulacros textuais tiveram algum impacto na prática de pessoas reais.

Que exista uma disciplina especializada no desenvolvimento científico de análise e descrição textuais é sem dúvida benéfico para a sociologia da cultura, e teve um considerável impacto nos estudos culturais das últimas décadas do século XX. Mas veremos no próximo capítulo, em autores como DeNora, Bourdieu e Hall um contraponto crítico à abordagem semiótica, assim como também procuraremos traçar algumas balizas conceituais para a nossa análise. 


\section{Capítulo III: Da gramática às práticas}

No capítulo precedente procuramos apresentar a abordagem semiótica da canção de Luis Tatit. O objetivo principal dessa teoria é desvelar os mecanismos de construção do sentido que estão inscritos no texto, e que agem sobre os receptores, mesmo sem a consciência deles a respeito. Por consequência, a abordagem semiótica, tal como feita por Luis Tatit, tende não somente a privilegiar o texto (entendido como qualquer espécie de forma produtora de sentido) enquanto fonte de sentido, mas também a isolá-lo como a única instância pertinente para a análise. Conforme a fórmula de Greimas repetida por Tatit mais de uma vez: «fora do texto não há salvação». Esse tipo de isolamento do texto em relação às práticas sociais de produção, circulação, avaliação e recepção, de todo o conjunto de instituições sem as quais ele jamais poderia existir enquanto tal ${ }^{75}$ é inaceitável para o sociólogo, interessado justamente na análise do conjunto de práticas e instituições. Conforme formulou Stuart Hall, a abstração do texto das práticas e instituições sociais onde eles são produzidos é uma fetichização (HALL, 2004, p.14). Ainda seguindo esse autor, o objetivo desta análise é traduzir não apenas o texto, mas também a cultura, num conjunto de práticas de produção de todo um modo de vida (seguindo a formulação de Williams) nas quais sentidos são socialmente construídos e historicamente transformados.

Essa forma de propor o objeto de estudo implica ao menos duas importantes mudanças de perspectiva. Em primeiro lugar, o texto não é mais $a$ instância produtora de sentido, mas um dos pontos (ainda que decisivo) de um circuito de práticas que colocam sentidos e representações em circulação na sociedade. Em segundo lugar, coloca-se o questionamento a respeito do status das práticas que compõem a cultura, uma vez que convencionalmente, para a crítica literária tradicional e mesmo para a semiótica ${ }^{76}$, os textos pertinentes e dignos de análise provêm do corpus das «grandes obras» canonizadas pelo tempo e pela crítica. Mas, ao colocar a cultura como o conjunto de práticas de representações, ela abarca não apenas as grandes obras, como também toda a gama de práticas e textos vulgares, populares, dessacralizados, como as obras de publicidade ou a canção popular.

Assim sendo, neste capítulo procuraremos abordar propostas para a compreensão da canção popular que lançam o pêndulo (ou torcem o bastão, como dizia Bourdieu) para o oposto da abordagem semiótica, ou seja, que se interessam pelos textos na medida em que

\footnotetext{
75 Temos em mente o artigo de Foucault, O que é um autor? [Ano, páginas].

${ }^{76}$ Nesse sentido é interessante notar que Luis Tatit, mesmo trabalhando com a canção popular, dispensa ao longo de sua obra um grande esforço em enobrecer e dignificar a canção, colocando-a no mesmo grupo de status das «grandes obras» culturais.
} 
eles integram um conjunto de práticas sociais, e na medida em que se torna possível construir nexos inteligíveis e empiricamente observáveis entre os textos e as questões sociais mais amplas, como poder, estratificação, classes e ideologia. Contudo, seria um erro simplesmente abdicar dos instrumentos de análise semiótica em nome da fidelidade disciplinar à sociologia. $\mathrm{O}$ desafio do modo de análise que pretendemos desenvolver ao longo deste capítulo reside em criar nexos entre os mecanismos textuais de construção de sentido (o objeto da análise semiótica) com as práticas sociais nas quais eles são acionados, utilizados, postos em circulação e em disputa. Mesmos autores como DeNora ou Bourdieu (com os quais trabalharemos a seguir) não hesitam em admitir que as obras culturais possuem propriedades objetivas que facilitam determinados usos e apropriações e ao mesmo tempo dificultam outros. Ou seja, as estruturas de sentido estudadas pela semiótica possuem, sim, uma existência relativamente autônoma e exercem influência. Uma desvantagem da sociologia da cultura, ao nosso ver, tem sido a de abdicar das ferramentas semióticas de análise para reafirmar a importância do seu objeto e modo de análise. Segue-se que muitas análises sociológicas ou passam totalmente ao largo do conteúdo de sentido das obras culturais, ou o tratam como se fosse algo evidente em si mesmo e dispensasse qualquer ferramenta analítica de clarificação ${ }^{77}$. Acreditamos que a elucidação das estruturas de sentido, oferecida pela semiótica, é importante também para as análises que focalizam as práticas e instituições sociais, se isso não for feito, corre-se o risco de perder completamente de vista a especificidade daquilo que compõe, por exemplo, o campo de produção cultural em relação ao campo de produção econômica propriamente dito. Nossa proposta, sumarizada no final do capítulo, será a de estabelecer nexos entre as práticas sociais e as propriedades de sentido elucidadas pela semiótica.

\section{Da gramática às práticas}

Se existe uma autora que se contrapõe completamente à análise semiótica da música, tal como a praticada por Luis Tatit, é Tia DeNora. No seu livro Music in Everyday Life, a autora procura desconstruir a visão, personificada em seu livro por Theodor Adorno, de que se possa presumir, a partir da leitura de uma peça de música, quais serão os seus efeitos sociais. Por outras palavras, a autora procura combater a noção de que o sentido de uma obra musical seja imanente, e demonstrar que a recepção articula os produtos musicais de modo ativo e reflexivo, algo muito distinto da noção de que as estruturas imanentes de um texto agem como um «estímulo» uniforme, que provocaria uma reação semelhante em todos os

\footnotetext{
${ }^{77}$ Este certamente não é o caso de Bourdieu ou DeNora. [Então por que é feita a proposição acima?]
} 
receptores. O trabalho de DeNora baseia-se em entrevistas com mulheres do Reino Unido e dos EUA, assim como em quatro etnografias (em aulas de aeróbica, em karaokês, em sessões de terapia musical e em lojas de roupa), nas quais ela aborda a música em seus contextos de uso, a música como um material dinâmico de estruturação da agência social.

Desse modo, a autora se posiciona contra a ideia de que «ler» as obras, no intuito de desvelar ou decodificar o seu conteúdo, seja suficiente, uma vez que atores sociais concretos em situações sociais concretas também decodificam as obras e as mobilizam em suas práticas, dos modos mais variados. Apesar de reconhecer que Adorno é o autor que foi o mais longe no esforço de reconhecer a força, o papel ativo da música e dos materiais estéticos na vida social, DeNora argumenta que ele não oferece nenhum recurso para a observação empírica dos efeitos que o autor lhe atribui. Seria preciso verificar como atores concretos, em seus usos e práticas musicais cotidianos, constroem os nexos entre música e sociedade, como a música articula elementos da vida social, assim como a vida social articula a música como ferramenta, veículo e modelo para a ação. Ou seja, o foco da análise não recai sobre o objeto estético e o que o analista é capaz de decifrar dele, mas sim no como práticas culturais mobilizam materiais estéticos para a produção da vida social (DeNora, 2004, p.6). A autora reconhece, como Adorno, similaridades estruturais entre o conteúdo musical e as práticas sociais nas quais ele se insere, mas com o cuidado de observar essas similaridades atuando na prática. Contra a presunção de que o significado musical seria imanente, inerente às formas musicais, a autora dirige o olhar para a maneira como atores concretos fazem coisas com a música, quais ações sociais a mobilizam como um material e como o fazem.

Um dos exemplos utilizados pela autora é o uso da música pelas companhias aéreas. Em uma viagem de avião, as companhias tendem a usar a música para a criação de um ambiente sonoro que inspire segurança, assim como para induzir determinados padrões de comportamento nos passageiros. Ou seja, nesse caso, ela funciona como um material em relação ao qual os atores sociais se situam para se orientar. A música funciona então como um recurso para construir cenários e definir situações, tanto por conta de suas características intrínsecas, como pelas relações convencionais entre música, cenários e usos sociais. Desse modo, uma peça dodecafônica ou uma peça dramática como a $5^{\text {a }}$ sinfonia de Beethoven dificilmente cumpririam a função de inspirar confiança durante o embarque num avião, assim como nenhuma peça musical seria capaz de, sozinha, inspirar confiança num avião em chamas. Ela funciona então como um material mobilizado reflexivamente, no sentido de que os atores não apenas recebem passivamente o estímulo musical, mas usam-no para a criação de estados de humor, cenários e situações que implicam determinados padrões de 
comportamento. Assim sendo, tanto fatores extra-musicais são mobilizados para atribuir sentido à música (como por exemplo os contextos de uso) assim como a música é usada para atribuir sentido a coisas que estão fora dela: criar ambientes, climas, humores, impulsionar o ritmo das vendas em uma loja ou sincronizar os movimentos numa aula de ginástica.

Em sua etnografia das lojas de roupa [Retail Store], a autora chega à conclusão de que o uso da música nesses espaços é feito de modo a controlar um ambiente, um framing device, a partir do qual é definida a especificidade da cena (no sentido de Goffman) que transcorre no interior das lojas, um dispositivo a partir do qual elas propõem determinados modos de comportamento, bem como especificam a qual clientela se dirigem. Desse modo, afirma a autora que a música pode ser e é usada como dispositivo de ordenação social, no sentido em que ela é acionada para organizar o comportamento de indivíduos. O ambiente auditivo é parte das referências que os atores usam para o monitoramento das situações, ela é parte do material cultural com que se constroem cenas, as quais propiciam diferentes modos de ação, diferentes maneiras de ser. A música organiza o comportamento de modo ainda mais direto e explícito nas aulas de aeróbica, onde as diferentes sessões da aula são definidas pela intensidade do ritmo musical, e, ao mesmo tempo, cada uma dessas sessões possui uma gramática de movimentos corporais pré-definidas. Chega-se à conclusão de que a música provê nessas aulas um material a partir do qual os atores organizam os processos corporais: motivação, percepção de cansaço e coordenação dos movimentos. Mas não apenas estados físicos como também subjetivos são intermediados pelas práticas musicais. A partir de entrevistas com mulheres do EUA e Reino Unido, a autora identificou o uso da música relacionado a estratégias de autorregulação do humor, como artefato ligado à memória autobiográfica e à construção da identidade.

Enfim, a autora mostra-nos como o uso dos materiais musicais não é um mero reflexo das estruturas semânticas inscritas nas obras, e que os atores utilizam reflexivamente a música como material para diferentes finalidades sociais, corporais e subjetivas. Porém, o ponto que mais nos interessa na discussão da autora reside em avaliar em que medida se pode falar de um sentido imanente às obras musicais, e em que medida o uso feito pelos atores relativiza a ideia, cara à semiótica, de estruturas imanentes de sentido. A autora pretende resolver a questão recorrendo à sociologia da ciência, ao modo como Bruno Latour equaciona a relação entre artefatos e os usos: é o artefato que determina as formas de uso ou são os usuários que determinam os usos do artefato? A resposta estaria na constituição mútua entre artefato e uso, entre as prescrições que estão inscritas no artefato e os comportamentos e cenas que o envolvem. Nesse sentido, os objetos proporcionam [to afford] certos usos, 
mas os usos efetivos serão determinados pelos usuários. A música, por sua vez, deveria ser compreendida como um recurso para práticas, para modos de ser e definir aspectos da realidade social, incluindo aspectos subjetivos. (DeNora, 2004, p.39). Determinados tipos de música proporcionariam recursos mais adequados para determinadas práticas, mas sem chegar ao ponto de determiná-las.

Podemos apontar o que acreditamos serem algumas debilidades do argumento de DeNora, assim como quais são, para os nossos propósitos, as contribuições da autora. A tentativa de equacionar o problema das práticas que se valem da música como material por meio do conceito de artefato implica, ao nosso ver, algumas questões. A primeira delas é que a música não é um artefato exclusivamente material como um revólver ou um liquidificador. Esses artefatos possuem uma existência material, e no momento de manufatura foram criados de acordo com certas finalidades práticas. É claro que tanto um revólver quanto um liquidificador podem adquirir uma existência simbólica e ir figurar em um museu (de Design, por exemplo), mas ainda assim não deixam de ser objetos. A música, por sua vez, pode ser definida como a prática de organização dos sons no espaço e no tempo, ao passo que o som é o resultado de vibrações produzidas por corpos sonoros ${ }^{78}$. Podemos facilmente identificar a materialidade dos instrumentos musicais bem como de suportes sonoros (discos e caixas de som), mas a música, embora seja um fenômeno físico, é o resultado efêmero de ondas sonoras, ainda que possa ser gravada e reproduzida. Desse modo, se fosse considerada como um artefato, ela seria uma espécie diferente de artefato. Ela é, característica que partilha com as outras artes, antes de tudo uma forma simbólica, ela não possui usos e funções inscritas em sua materialidade. Portanto, embora possamos admitir sem problemas que a música seja usada como material, esse seu uso não advém da sua materialidade, como ocorre com os demais artefatos. Os usos musicais e extramusicais da música, conforme formulou Richard Middleton (citado pela própria DeNora), advêm do sistema de relações entre sons e das analogias que podem ser feitas entre eventos musicais e extra-musicais:

Music, too, considered as a structural-semantic system, offers a means of thinking relationships, both within a work and between works, and perhaps between these and non-musical structures. Musical patterns are saying: as this note is to that note, as tonic is to dominant, as ascent is to descent, as accent is to weak beat (and so on), so $\mathrm{X}$ is to $\mathrm{Y}$. And, of course, these relationships obtain in different syntaxes, with different associations (connotations). (MIDDLETON, 1990, p.223)

78 Bohumil Med. Teoria da música. Brasília: Musimed, 1996. 
Assim sendo, um entendimento mais adequado da inserção da música nas práticas sociais não pode ignorar o aspecto «estrutural semântico», conforme formulado por Middleton. Acreditamos que a música seria mais proveitosamente analisada no quadro das práticas simbólicas do que pelo conceito de artefato formulado pela sociologia da ciência. Ainda assim, devemos assinalar a contribuição de DeNora na compreensão do papel ativo da música na sociedade, bem como da importância de observar os nexos entre música e sociedade na prática de atores sociais concretos. Justamente esse ponto traz uma reflexão importante a respeito da prática semiótica, quando se propõe a ler e desvelar os sentidos de um texto. A prática da escuta musical em busca de um sentido é apenas uma das possíveis práticas de escuta: seja na dança em uma casa noturna, seja como pano de fundo em uma loja ou em um jantar entre amigos, existe uma série de práticas em que o sentido que as estruturas musicais trazem em si mesmas fica em segundo plano. Portanto, levando adiante a reflexão em torno da música em relação às práticas sociais, abordaremos em seguida o papel da canção dentro das práticas sociais de representação.

\section{Canção e prática da representação}

Uma vez que DeNora salientou o papel ativo da música nas práticas sociais, gostaríamos agora de especificar o papel da canção como um tipo específico de prática: a de representação. Partimos aqui da discussão feita por Stuart Hall em The Work of Representation, segundo a qual a cultura deve ser compreendida não como um conjunto de coisas ou obras, mas sim como um conjunto de sentidos e práticas, um repertório não unitário, não unívoco, de sentidos partilhados, que organizam e regulam as práticas sociais. Considerando a cultura como prática de atribuição e circulação de sentidos, a língua surge como o meio privilegiado de realização das práticas culturais, pois ela é um sistema de representações, um sistema de signos que representam ideias, conceitos ou sentimentos. É a língua, enquanto sistema de representações, que permite a atribuição de sentido tanto ao universo dos objetos quanto ao dos conceitos e sentimentos, numa forma que pode ser partilhada, transmitida, mas também disputada e negociada. Mas não somente a língua na acepção de um idioma, como também um conjunto de sons, gestos, expressões faciais ou roupas podem funcionar como uma língua, uma vez que servem de veículo, meio para a representação de uma outra coisa que não eles mesmos; ou seja, fazem a ponte entre o objeto, a representação mental (significado), e a palavra, som ou qualquer outro meio portador de sentido (significante). Desse ponto de vista, todos os objetos culturais portam sentidos e todas as práticas culturais dependem do sentido. Uma vez que elas fazem uso dos signos, 
tornam-se passíveis de uma análise semiológica, análise dos códigos e estruturas de sentido subjacentes, das regras pelas quais os objetos e práticas produzem sentidos. Por exemplo, um pedaço de pano que recobre um corpo pode adquirir o sentido denotado de vestido, assim como ser associado a códigos como elegância, feminilidade, classe social, faixa etária, etc. (sentidos conotados).

Richard Middleton (1990, p. 232) apresenta uma lista interessante de sentidos conotados que podem emergir dos eventos musicais (os sentidos denotados, por sua vez, decorrem da classificação de determinados eventos sonoros como «música» e não como ruído). Eventos sonoros podem adquirir intencionalmente conotações como «moderno» para um timbre sintético (valores intencionais). Pode receber a conotação de repouso, tensão, passagem etc. segundo a sua posição na cadeia sonora (implicações posicionais); receber leituras interpretativas que se impõem como verdadeiras (conotações ideológicas); associação com estados afetivos específicos tal como o punk e a agressividade, o soul e a religiosidade (conotações emotivas); associação com outros sistemas semióticos como o visual, olfativo, sensorial; conotações associadas ao estilo tal como rock e juventude; ou ser associado a um conjunto de valores morais, políticos, religiosos etc. (conotações axiológicas). É justamente pelo fato de os eventos musicais poderem receber esses valores denotativos e conotativos que se pode falar em uma linguagem musical, tanto no sentido próprio (os sentidos que as estruturas sonoras adquirem em relação às outras estruturas sonoras, tanto dentro de uma mesma peça - daí falamos em introdução, tema, riff, ponte quanto em relação às outras peças - estabelecendo então as diferentes formas musicais como canção, sonata, sinfonia etc., ou seja, denotado), quanto no sentido figurado (os valores denotativos listados acima).

Desse modo, compreende-se língua antes de tudo como um sistema, um princípio de classificação, arranjamento, organização de sentidos. A cultura, enquanto prática da representação, precisa da língua como meio para a produção, partilha e decodificação das representações. A incorporação de conceitos, ideias e emoções em formas simbólicas que podem ser transmitidas é o que Stuart Hall (2013) denomina práticas da representação, que se realizam nos e pelos objetos culturais portadores de sentido. É importante frisar o ato da representação como prática, uma vez que a relação entre objeto, significante e significado é flutuante, ela muda de acordo com o uso, contexto, momento histórico e localização geográfica. A representação depende de práticas e, portanto, é passível de ser modificada, assim como uma mesma cultura pode conter diferentes circuitos de sentido circulando ao mesmo tempo dentro de si. Isso nos remete ao que Saussure designou como a relação 
arbitrária entre significante e significado: é necessária a existência de um código que correlacione significante e significado, que fixe as relações entre conceito e signo. O signo, por sua vez, tem a capacidade de designar objetos não por semelhança ou qualquer tipo de relação natural com ele, mas sim pelas distinções entre signos, é o sistema de diferenças entre signos que permite operar distinções e, por conseguinte, atribuir significados.

Desse modo, podemos considerar a canção popular como uma prática cultural, justamente por sua capacidade de criar representações e colocá-las em circulação na sociedade. A canção popular é um dos espaços em que sentidos são atribuídos, partilhados, mas também questionados, disputados ou combatidos. Pense-se a esse respeito (é justamente isso que pretendemos fazer nos capítulos posteriores) nas diferentes representações de um Brasil moderno nas canções da Bossa Nova, da Tropicália ou da Vanguarda Paulista. As mais distintas representações e conotações de modernidade brasileira foram feitas e colocadas em circulação nessas canções, contribuindo para a construção de sentidos socialmente partilhados a respeito não somente do que o Brasil moderno é, mas também o que seria ou poderia ter sido, assim como o que ele não é e não foi.

Contudo, não somente a produção das representações, mas também o impacto das formas de circulação deve ser considerado. É claro que, em se tratando da canção popular, sua circulação se dá através da mídia, dos meios de reprodução técnica que estão, no mais das vezes, vinculados a empresas de grande porte, as quais realizam seu lucro sobretudo pela distribuição e venda em massa de seus produtos. Se olharmos, segundo Stuart Hall (2004), a estrutura do processo de comunicação nos meios de massa, podemos pensar esse processo, à semelhança da forma mercadoria analisada por Marx, como uma sequência de transformações, que se dá na sequência de momentos articulados, mas distintos, de produção, circulação, distribuição, consumo e reprodução. Ou seja, as práticas de produção de sentidos nas mídias podem ser vistas como um ciclo que coloca signos em circulação, mas que depende de uma sequência de diferentes formas de arranjo desses signos.

O momento principal desse ciclo é a forma mensagem, uma vez que sem a transformação dos eventos em uma forma linguística, eles não podem ser postos em circulação por nenhum meio de comunicação Por outras palavras, a história tem que se transformar em "estória" para poder ser comunicada; tem de submeter-se aos códigos de uma língua. Esse momento de transformação do evento em ato comunicativo, Hall denomina de codificação, momento necessário para que a mensagem possa entrar em circulação e ser finalmente decodificada pelos receptores. Codificação e decodificação não são momentos simétricos, uma vez que a decodificação depende de um trabalho ativo do receptor, e, por 
sua vez, dos conhecimentos e códigos que estão à disposição do receptor segundo a sua posição social:

Before this message can have an 'effect' (however defined), satisfy a 'need' or be put to a 'use', it must be first be appropriated as a meaningful discourse and be meaningfully decoded. It is this set of decoded meanings which 'have an effect', influence, entertain, instruct or persuade, with very complex perceptual, cognitive, emotional, ideological or behavioral consequences. In a 'determinate' moment the structure employs a code and yields a 'message': at another determinate moment the 'message', via decodings, issues into the structure of social practices. (HALL, 1980, p.119)

Decorre disso que a mensagem codificada não age como um simples estímulo, um "golpe no joelho" como uma reação reflexa, uma vez que sua decodificação depende dos recursos e das competências do receptor. Ao mesmo tempo, seria incorreto acreditar que a codificação não constrói nenhum limite ou parâmetro para a decodificação. Há de haver algum grau de correspondência entre a mensagem codificada e a mensagem decodificada, ou então o próprio processo de comunicação estaria ameaçado. Sem dúvida existem desentendimentos, assim como a grande maioria das mensagens está aberta há uma pluralidade de leituras, mas a própria existência de relações de poder dentro de uma sociedade e da cultura implica a imposição de determinadas espécies de «leitura», determinadas atribuições de sentido que são preferidas em relação às outras. Existem leituras dominantes uma vez que sentidos adquirem o peso das ordens institucionais, políticas e ideológicas na sua legitimação, impondo por vezes limites e sanções a leituras heréticas dos códigos. Desse modo, diríamos que as relações de poder se expressam também no domínio semântico, quando se procura legitimar determinada leitura em detrimento de outras.

As práticas culturais de representação, assim como as disputas políticas no domínio cultural (e semântico), não são práticas e lutas unicamente simbólicas, «fora» da realidade concreta, uma vez que, sempre que nos referirmos à realidade fora da língua, só podemos fazê-lo por intermédio dela. Tudo o que sabemos, dizemos, bem como o sentido dado às práticas tem de ser articulado pela linguagem. Desse modo, não apenas a atribuição de sentido aos eventos é necessariamente articulada pela representação, como também não há uma representação transparente do real, mas a sua articulação numa língua. Não se lê $a$ realidade na mensagem, embora seja possível supor a existência de tal realidade «fora» da língua, mas uma codificação de signos que a representam, e cuja leitura também não está livre de uma ordem de disputas em torno da decodificação legítima. 


\section{A representação do "eu" na canção popular}

Podemos agora detalhar melhor os mecanismos de representação da canção. Luis Tatit esclarece com propriedade os mecanismos semióticos de produção do sentido na canção, mas o isolamento do texto em relação às práticas sociais de produção, circulação e mesmo às de decodificação (ou simplesmente leitura) dos textos pode ser aceitável para a semiótica, enquanto disciplina especializada na análise do sentido textual (verbal ou não), mas não o é para a sociologia. Assim, gostaríamos de colocar agora não somente a questão a respeito de como as canções constroem as suas representações, mas quais homologias e funções podem existir entre elas e as representações feitas em outros domínios da vida social. É o próprio Luis Tatit quem melhor esclarece o vínculo da canção com a fala cotidiana, com o uso de expressões e entoações do uso cotidiano da fala. Assim, buscaremos agora explorar as potencialidades da teoria de Erving Goffman sobre a representação do "eu" na vida cotidiana para o estudo sociológico da canção popular. Nosso argumento é que podemos abordar as canções como uma forma expressiva que, assim como demais formas sociais de expressão, trabalha de modo a operar uma estilização dos materiais da vida cotidiana para infundi-los com um significado para o ouvinte. Argumentamos também que a canção é uma forma especialmente interessante enquanto forma de representação de um "eu”, pois na voz que entoa, há sempre uma persona que se expressa, sujeito que fala pela voz da canção.

O uso de Goffman para análise da canção popular não é algo inédito. Philip Auslander esboça, em dois artigos (2004, 2009), possíveis modos de uso da teoria de Goffman na análise da canção. Seu objetivo foi o de encorajar «close readings», dirigir a atenção para as particularidades dos movimentos físicos, dos gestos, das roupas, expressões faciais assim como da voz e do som nas performances musicais. Contudo, diferente de Auslander, nosso objetivo não é privilegiar a análise das performances ao vivo ou em videoclips, ou seja, as performances visuais da música, mas sim a performance propriamente sonora da canção, embora muitas sugestões do autor nos sejam valiosas. Em primeiro lugar, é digno de nota a observação de Auslander de que mesmo as gravações também são performances (AUSLANDER, 2004, p.5.). Mesmo com a ausência física do artista, os ouvintes não percebem a música como algo «desincorporado» [disembodied], mas sim como o resultado de gestos físicos, gestos corporais que produziram aquele som e que provocam no ouvinte uma reação igualmente gestual/corporal: dançar, estalar os dedos, chacoalhar a cabeça («bater cabelo»), tocar guitarras e baterias imaginárias. Richard Middleton (1990) também argumenta com persuasão que a música está enraizada no corpo humano: ela é o 
resultado de gestos físicos traduzidos em som, gestos corporais traduzidos pelos ouvintes em outros tantos gestos corporais. Lembremo-nos aqui das formas de persuasão temática e passional discutidas por Tatit e chegaremos às conclusões de Middleton de que a música promove a partilha de estados somáticos, a socialização de sensações e experiências de estados físicos/emocionais, transformados em formas visíveis, audíveis e transmissíveis.

Mas é justamente na transformação da experiência em forma que reside o interesse da canção. Pois se mesmo uma gravação provoca a sensação de uma performance que se desenrola no aqui agora da escuta, a sensação de um corpo e seus estados físicos e psíquicos, devemos indagar-nos a respeito dos códigos dessa transformação, o modo de articulação (como discutida por Hall) numa linguagem capaz de expressar e dar sentido e colocá-lo em circulação. Abre-se mais uma dimensão para o questionamento sociológico a respeito das canções populares. Isso pois, para além de uma análise interna ou externa das canções, poderíamos nos questionar também a respeito dos códigos de expressão e representação que operam nelas e suas homologias com os demais códigos mobilizados nas representações da vida cotidiana.

Podemos indagar a respeito de tais códigos pois, ainda que admitíssemos a hipótese de um "eu profundo" que se expresse nas canções, fica evidente a necessidade da mediação de toda uma série de códigos de expressão para que a subjetividade de um compositor tome a forma de uma canção, como ilustra um poema de Goethe:

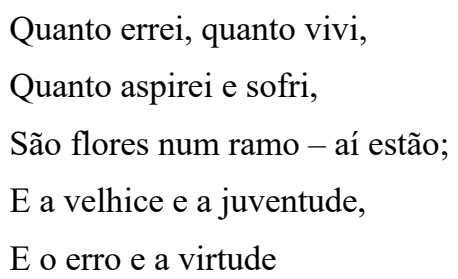

Se o "quanto vivi, quanto aspirei e sofri” ficam bem numa canção, isso quer dizer que poderiam não figurar tão bem de outro modo. Há um esforço em configurar esse material numa forma que seja agradável, bela. Do ponto de vista de Goffman, poderíamos pensar na representação do "eu” nas canções. Nelas há um arranjo teatral de códigos de representação para dar uma forma musical e convincente ao "eu" que quer expressar-se por canções. Isso remete-nos à função da mímesis que opera nessa forma artística, pois, uma vez que nas canções há o esforço de representar um "eu” de forma convincente, devemos indagar-nos a 
respeito dos procedimentos miméticos pelos quais se realiza essa operação de representação. A mímesis talvez seja o recurso mais poderoso de encantamento do ouvinte que se deixa levar pela ilusão de real. Assim como na pintura renascentista o ideal artístico era uma ilusão perfeita de real, algo que enganasse tão perfeitamente os olhos a ponto de levar passarinhos a bicar as uvas pintadas na tela, na canção ainda existe a busca por uma ilusão de realidade, um pleno convencimento do ouvinte a respeito da veracidade do sentimento representado.

Auslander distingue três dimensões da representação do Self nas canções: a pessoa real [real person], a persona e o personagem [character], as quais configuram três camadas, três vozes articuladas pela voz da canção. A pessoa real é o artista/performer ele mesmo, a pessoa portadora de uma certidão de nascimento e conta bancária, como Robert Allen Zimmerman ou Stefani Joanne Angelina Germanotta; ao passo que a persona é o personagem desempenhado pelo artista ao longo de sua carreira tal como Bob Dylan ou Lady Gaga, respectivamente. O personagem, por sua vez, é o personagem de uma canção específica, que pode ter um nome próprio e mesmo aparecer em várias canções. Evidentemente, a barreira entre cada uma dessas instâncias é sempre fluida. O autor afirma que a pessoa real é a dimensão da qual o público possui menos informações, uma vez que mesmo a biografia fora dos palcos é muitas vezes mediada pela construção da persona. Esta é performada não apenas nos palcos, mas também nas imagens, entrevistas, filmes e demais produtos associados ao artista. A persona é uma criação coletiva, feita em colaboração com agentes, publicitários, produtores e demais pessoas envolvidas na criação da imagem/personalidade do artista. Ainda assim, o artista não deixa de ser em parte a pessoa real: Bob Dylan não é exatamente o mesmo que Robert Zimmerman, mas Robert Zimmerman não deixa de ser Robert Zimmerman quando é Bob Dylan. Já o personagem, segundo Auslander, entra em cena somente quando é explicitamente articulado pelo texto, ao passo que o «eu» implícito nas cenas, ações e sentimentos retratados na canção, sem receber um nome ou características específicas, seria a representação da persona sem mediação. Acreditamos que essa forma de distinção não seja conveniente, no sentido de que mesmo quando o personagem não é articulado explicitamente, é possível perceber que há um personagem da canção, muitas vezes explicitamente distinto da persona do cantor. É interessante notar que em muitas ocasiões, a personagem da canção não é o narrador, mas sim o objeto descrito na narrativa. Ainda assim, a distinção entre pessoa real, persona e personagem é analiticamente útil ${ }^{79}$.

\footnotetext{
79 Vale notar que Auslander se baseia em Simon Frith (1990), o qual distingue entre a voz instrumento, voz corpo, voz pessoa e voz personagem.
} 
A perspectiva que se abre aqui é a de analisar a canção não "apenas" como música, mas também, ou mesmo até mais como uma forma onde se representam papéis, onde a fala cotidiana é estilizada para se criar personas e personagens que desempenham papéis em narrativas. Talvez não seja absurdo dizer que a canção seja menos música do que monodramas com ambientação musical:

\footnotetext{
Musicians do not only play music; they also play roles [...] performers seek to create an impression of who they are, their relationship to the music, the nature of the interrelations among themselves, and the kind of interaction they are offering to the audience. Such impressions are created both aurally and visually and imply a social narrative. (AUSLANDER, 2009, p. 305)
}

Temos na canção popular uma forma artística na qual uma série de elementos concorrem para a expressão e a representação de uma persona, pouco importa se tal representação seja um ato sincero ou cínico por parte do compositor. Mas ainda nos resta esclarecer como se dá a codificação da persona no texto da canção. Aqui iremos nos valer da teoria sociológica de Erving Goffman para o estudo dessa forma artística, para vê-la sob a perspectiva de uma reconstrução da vida social por meio do agenciamento de recursos expressivos sonoros, linguísticos e mesmo visuais. A seguir, tentaremos mapear as potencialidades do pensamento de Goffman para o estudo da canção.

\subsection{As potencialidades de Goffman para se pensar a canção}

Nos parágrafos seguintes trabalharemos com duas obras de Goffman: $A$ representação do Eu na vida cotidiana e Gender Advertisements. Com a primeira, teremos acesso ao arsenal teórico desenvolvido por Goffman a partir da metáfora teatral para o estudo de situações sociais de co-presença. Já na segunda, poderemos ver como o agenciamento de recursos expressivos pode ser usado para a representação de estruturas e hierarquias sociais em situações de pequena escala.

\section{Representação e exibição}

No livro $A$ representação do Eu na vida cotidiana, Goffman utiliza a performance teatral - as maneiras como o indivíduo apresenta a si mesmo e suas atividades aos outros, os modos pelos quais ele guia e controla a impressão que formam dele e os tipos de atitude que pode e não pode tomar enquanto sustenta sua performance diante deles - como uma metáfora e guia para a compreensão de situações de co-presença, quando indivíduos se encontram 
face a face. Nessas interações, é crucial que o indivíduo se expresse de modo a definir a situação, manipular a impressão da plateia e emitir informações que lhe permitam prever o seu comportamento. Uma vez que, durante a interação, não há meios de obter provas conclusivas a respeito do indivíduo, é necessário que ele se expresse e que os outros sejam por ele impressionados de modo que a interação se desenrole de modo satisfatório, de acordo com seus interesses.

Ou seja, o que Goffman mostra é que tanto no mundo das práticas artísticas quando no mundo das práticas sociais, lida-se com representações. Não só na arte, como na vida social, é-se obrigado a julgar pela aparência. É preciso inferir, a partir de um conjunto de sinais propositalmente orquestrados pelo ator social para dar determinada impressão, quem ele é, qual papel pretende representar, e o que ele espera de nós. É uma particularidade do mundo social que os objetos e sinais a partir dos quais se fazem inferências para saber o que está acontecendo propositalmente facilitam ou dificultam esse processo inferencial (GOFFMAN, 1985). Quanto mais haja interesse em uma situação, quanto mais se queira descobrir a "verdade" do que está acontecendo, tanto mais é necessário dirigir a atenção para os detalhes, para os sinais que transmitem informações. Nas situações sociais de copresença, a representação faz-se necessária para que haja entendimento da situação, para que seja definido o que está acontecendo e os indivíduos envolvidos ajam de acordo com o esperado. De modo que, na representação cotidiana, há também o esforço para manipular não somente a impressão como também a resposta da plateia.

Conforme foi visto com Tatit, a canção é também uma empresa de manipulação. O emissor procura a todo momento persuadir o ouvinte, seja pela sedução das curvas melódicas que convidam o corpo para a dança, pelo retrato de estados passionais, pela representação de uma "verdade enunciativa": de que a voz que canta poderia muito bem ser uma voz que fala, uma voz que está ali e nos diz alguma coisa, fala diretamente para nós e para o nosso corpo. Há na canção um arranjo de sinais para a criação de um efeito de verdade, verossimilhança e persuasão do ouvinte. Mas como se dá a interação propriamente dita entre enunciador e destinatário? Pode-se falar nesse caso em interação? A resposta seria obviamente afirmativa no caso da performance ao vivo, onde a premissa da co-presença de ator e plateia é mantida. Não seria tão óbvia assim no caso da audição intermediada por uma mídia qualquer. Mesmo nesse segundo caso, entretanto, o movimento de expressão por parte do emissor e de impressão do receptor, que caracteriza a representação na vida cotidiana, faz-se presente, ainda que intermediado. Na sociedade contemporânea, é comum que artista e plateia interajam pela mediação dos meios de comunicação de massa e do mercado, o que 
leva o número de pessoas envolvidas na interação a atingir proporções colossais quando comparado às situações face a face. Ainda assim, podemos afirmar que as canções são compostas e trabalhadas para causar determinadas impressões nos ouvintes, caracterizando um movimento de expressão e impressão análogo às situações de co-presença estudadas por Goffman.

Deve-se levar em conta as novas possibilidades de manipulação de impressão que as mídias colocam à disposição do enunciador. Uma interação sonora gravada não é a mesma coisa que uma interação sonora face a face, assim como a cena de um filme não é a mesma coisa que um teatro filmado. Lembrando de Benjamin em $A$ obra de arte na era de sua reprodutibilidade técnica, a manipulação das cenas por meio das câmeras, dos cortes, dos zooms oferece ao espectador a possibilidade de uma experiência óptica do mundo até então impossível. Pode-se ver uma cena dos mais diferentes ângulos, pode-se aproximar o olhar dos detalhes de um modo que não é quando se está de corpo presente. Do mesmo modo, conforme descreve Simon Frith a respeito das técnicas de microfone de Frank Sinatra (1990, p.188), o uso do microfone permite ao cantor aproximar a sua voz, permite que os ouvintes o escutem como se sussurrasse aos seus ouvidos, de um modo que, na vida real, apenas uma pessoa muito íntima ouviria, assim como um close no rosto de um ator de cinema permite observá-lo de um modo que, na vida cotidiana, apenas os parceiros mais íntimos são olhados. Ou seja, o uso do microfone permite a construção de uma dimensão espacial na gravação, permite que se escute a voz mais próxima ou mais distante, sussurrada ou gritada, o que implica também diferentes formas de interação propostas ao ouvinte. Em suma, as mídias não são registros passivos, mas mais um instrumento na construção da mensagem final, na construção de uma representação apesar de tudo verossímil.

A necessidade de dar forma adequada às atividades que se executa, às maneiras de apresentar-se, de se mostrar e tentar definir quem se é, de tentar transmitir ideias e sentimentos de uma maneira que seja agradável, aceitável ou até mesmo bela não se trata, afirma Goffamn, de uma mera coincidência entre a vida cotidiana e a representação nos palcos: "Os textos dramáticos podem ganhar vida porque a própria vida é uma representação dramática" (GOFFMAN, 1985, p.71). O autor sustenta que os indivíduos são socializados, capazes de interagir em sociedade e antecipar o que se espera deles em determinadas situações pois aprendem as regras para a representação de determinados papéis e um número suficiente de formas de expressão. Que as ações, sentimentos e formas de conduta apresentados nessas representações cotidianas sejam falsos ou verdadeiros, bemintencionados ou dissimulados, em ambos os casos terão de fazer uso de sinais, de 
aparências, pois é esse o âmbito ao qual a plateia tem acesso. Assim sendo, o autor argumenta que, além das abordagens sociais que consideram as dimensões política, estrutural, técnica e cultural da sociedade, a abordagem dramatúrgica deveria ser adicionada, uma vez que ela leva os atores a descreverem as técnicas de manipulação da impressão, quais problemas podem surgir ao fazer isso, bem como constrói a identidade dos agentes e equipes que operam as representações (GOFFMAN, 1985, p.220). Mas não apenas, como também se entrecruza com questões das outras dimensões. A dimensão dramatúrgica entrecruza com questões da estrutura social, na medida em que grupos de status marcam distância uns dos outros mediante técnicas de representação, e culturais, na medida em que a cultura fornece um quadro de valores, a partir dos quais se estabelece o que é desejável ou não representar. Dramaturgia e política se entrecruzam na medida em que a representação dá a capacidade de manipular e dirigir a conduta do outro:

\footnotetext{
Qualquer tipo de poder deve estar revestido de meios eficientes que o exibam, e terá diferentes efeitos, dependendo do modo como é dramatizado [...] Assim a forma mais objetiva de poder nu, isto é, a coerção física, frequentemente não é, nem objetiva nem nua, mas funciona principalmente como uma exibição para persuadir a plateia; é frequentemente um meio de comunicação e não simplesmente um meio de ação (GOFFMAN, 1985, p.221)
}

Uma abordagem sociológica da canção, que também leve em conta os dispositivos semióticos de construção de sentido do seu conteúdo ganha relevância quando se abre a dimensão dramatúrgica da vida social. A canção é uma prática de representação como outras tantas que se praticam na vida cotidiana; elas são empresas de comunicação/persuasão, em que o enunciador procura ganhar a aceitação do ouvinte, que o ouvinte goste da canção, deseje ouvi-la mais vezes, deseje ir ao show e comprar os discos do cantor. Nessa direção, pode-se dizer que a manipulação da impressão feita pelo artista procura, ao menos em certa medida, a aceitação do ouvinte, o reconhecimento do ouvinte. Reconhecimento não apenas do mérito da canção, mas que o ouvinte se reconheça nela, adote a canção como uma representação bem executada de aspectos da vida social cotidiana: uma canção que traduza perfeitamente a dor de uma separação, a alegria do encontro, a revolta política, uma cena do cotidiano. O ouvinte que aceita a manipulação da canção tem grandes chances de aceitar a definição de situação que ela propõe a respeito do assunto que aborda, às vezes mesmo sendo isso conflitante com o grupo de origem social do ouvinte. Talvez não exista exemplo 
mais claro do poder da canção de definir uma situação e, com isso, uma perspectiva a respeito do mundo social do que esse trecho dos Racionais Mcs:

\author{
Inacreditável, mas seu filho me imita \\ No meio de vocês \\ Ele é o mais esperto \\ Ginga e fala gíria \\ Gíria não, dialeto \\ Esse não é mais seu \\ Ó, subiu \\ Entrei pelo seu rádio \\ Tomei, cê nem viu \\ Nós é isso ou aquilo \\ O quê? \\ Cê não dizia? \\ Seu filho quer ser preto \\ Rááá \\ Que ironia
}

Porém, a capacidade da canção de manipular a impressão, definir a situação e com isso, impor uma visão, um ponto de vista a respeito do mundo social (e acredito que se deve falar em mundo social mesmo no caso de uma canção que aborde o universo afetivo, pois ela trata de uma dimensão socializada do universo afetivo) está vinculada a sua capacidade de representar o mundo social em pequena escala. Em alguns meros minutos, com apenas algumas palavras, muitas vezes articuladas na voz de um único cantor, a canção é capaz de construir "miniaturas": narrativas capazes de condensar o que poderia ser tema de um longametragem inteiro. Isso aproxima a canção daquilo que Goffamn chama de exibições [Displays] de comportamento, situações de pequena escala onde materiais e indivíduos são organizados para retratar o que é considerado como o seu lugar em quadros sociais mais amplos, metáforas em pequena escala das hierarquias e da estrutura social. Essas exibições possuem a capacidade de reafirmar, por suas metáforas, as organizações sociais básicas e os valores axiológicos que lhes são subjacentes; portanto, de funcionar como cerimônias políticas, devido a sua influência estabilizadora (ou desestabilizadora) ao subscrever (ou não) a ordem social. Isso, por sua vez, devido àquilo que Goffman entende por ritualização de um comportamento: a formalização de gestos, com a intenção de realçar o seu aspecto 
informativo (GOFFMAN, 1976, p. 1). Ou seja, para que um ator transmita a sua plateia uma disposição amigável, poderá performar um sorriso ou um aperto de mão no momento de sua aparição, transmitindo assim a informação desejada. Esse recurso social de formalizar comportamentos, para facilitar e realçar o seu teor informativo, permite a Goffman analisálos como um Display. A vida social é permeada de exibições de comportamentos expressivos, dado que tais exibições funcionam como guias de percepção, transformam as atitudes dos agentes em algo facilmente perceptível e compreensível. A ritualização dos comportamentos possui a propriedade de tornar palpável aos sentidos aquilo que se desenrola, dá uma interpretação inteligível e manipulável das situações sociais, que sem isso permaneceriam opacas e polissêmicas. Os displays são, portanto, guias exortativos de percepção.

Os displays de comportamento podem ocorrer não apenas nas situações face a face. Goffman dedica o texto Gender Advertisements ao estudo da ritualização de comportamentos de gênero nos retratos publicitários. O interessante nesse estudo está no argumento de que a publicidade não apenas oferece retratos enviesados a respeito do que é ser homem ou mulher, mas que tais retratos servem de modelos e fonte de orientação sobre o que é ser homem ou mulher. São como uma espécie de cerimônia onde se oferecem descrições ideais a respeito de como cada um dos gêneros se deve portar, quais são os ideais que devem ser confirmados nas exibições cotidianas de comportamento. Goffman aponta nos retratos comerciais como o tamanho relativo das personagens no retrato e sua altura são indicativos da hierarquia social entre essas figuras, como o toque feminino nos objetos é um toque não utilitário, sensual, ao passo que o toque masculino é utilitário e firme. Esse autor também mostra como se dá a ritualização da subordinação nesses retratos, por meio de posições corporais: as torções do corpo, o sorriso, as formas de tocar o próprio corpo, a maneira de vestir uniformes e de incorporar papeis sociais mais como uma criança brincando com uma fantasia do que um adulto que os vista a "sério". É uma questão significativa o fato de os displays de comportamento oferecerem estereótipos que orientam e guiam os indivíduos na vida cotidiana, induzindo-os a darem um significado e uma forma legível às suas próprias identidades.

A canção popular seguramente pode ser compreendida como um display de comportamento, além de uma forma de expressão do "eu", pois, como nos demais, nela um agenciamento de materiais expressivos - sejam eles linguísticos, gestuais ou sonoros - que concorrem para uma representação estereotipada de um personagem ou fato da vida cotidiana. Estereotipados porque, nas representações em geral, lida-se sempre com tipos de 
personagens e comportamentos. Por exemplo, na canção Valsinha de Vinícius de Morais e Chico Buarque, pode-se rapidamente, na narrativa, identificar o marido de personalidade amarga e a esposa reprimida pela descrição de comportamentos típicos desses tipos de papéis sociais: "E não maldisse a vida tanto / Quanto era seu jeito de sempre falar / E nem deixoua só num canto / Pra seu grande espanto, convidou-a pra rodar / E então ela se fez bonita / Como há muito tempo não queria ousar / Com seu vestido decotado / Cheirando a guardado de tanto esperar".

Um estudo das canções populares que se dedicasse a analisar as representações de gênero nas canções, como se constroem as personas e personagens femininas e masculinas, poderia mostrar assimetrias de gênero muito sintomáticas: a voz masculina é na maioria dos casos um narrador mais distante do seu papel e dos sentimentos do que a voz feminina que, por sua vez, denota muito mais diretamente um corpo sensual e sentimentos afetivos pungentes. Pense-se a esse respeito o dueto de Chico Buarque e Maria Bethânia em Sem Fantasia, ou na música pop anglo-saxã dos dias atuais em que a voz masculina é geralmente responsável pelos trechos de Rap da canção, pela fala «dura», viril e agressiva, ao passo que a voz feminina se encarrega do refrão, dos arroubos passionais e da sensualidade.

A eficácia expressiva da canção e a sua função celebradora do "eu" social que nela se expressa advém do fato de ela valer-se da mesma linguagem, do mesmo "idioma ritual" de que a sociedade se vale em outras esferas de representação e atribuição de significado. Vale para a canção, enquanto display de comportamento, o mesmo que afirma Goffman a respeito das propagandas: a publicidade e a sociedade possuem a mesma tarefa de infundir sinais rituais e cerimoniais nas situações, transformar situações opacas em formas facilmente legíveis (GOFFMAN, 1976, p. 27). Isso ocorre, não por conta de uma extraordinária coincidência entre a canção popular e a publicidade, mas sim porque todas as formas de retratar e simbolizar a vida social se deparam com essa função e esse desafio: construir uma cena, representar categorias, tipos de pessoas e suas relações hierárquicas entre si, bem como reafirmar os valores fundamentais que devem ser inculcados nas representações de si e práticas cotidianas.

\section{Fachada e cenário}

Pensando então na canção como miniatura, metáfora em pequena escala de organizações sociais mais amplas, seria interessante ver como espaços são construídos na canção, espaços de fachada, fundo, cenários etc. Mas como os conceitos de fachada e cenário, usados por Goffman para a análise da vida cotidiana se aplicariam no caso da 
canção? Em primeiro lugar, é preciso pensar na figura do emissor, o artista, e o papel que lhe cabe representar diante da plateia. Goffman define a fachada pessoal como o conjunto de atributos expressivos, os veículos de transmissão de sinais do ator (GOFFMAN, 1985, p. 31). Entre eles estão a aparência, os estímulos que informam a respeito do status social do ator; e a maneira, os sinais que informam aos espectadores o papel a ser representado na interação. Toda plateia exige coerência entre aparência e maneira, entre o status social do ator e o papel que ele exerce na interação. Esse fato da vida cotidiana estende-se também ao mundo do espetáculo. Todo ouvinte carrega a expectativa de coerência entre o emissor e a mensagem, entre o ator e o papel, por mais ingênua e injustificada que seja por vezes essa expectativa. Por exemplo, o fã de um grupo de rap agressivo, que narra a cruel realidade da periferia nas suas letras, ficaria certamente decepcionado se o autor dessas letras fosse um garoto rico que precise de permissão dos pais para sair do condomínio fechado onde mora, ainda que tal fato em nada diminua o mérito literário das suas canções. Podemos pensar em exemplos menos extremos: o autor de canções românticas não precisa necessariamente estar apaixonado ou ser um galanteador inveterado. Canções que falam da vida sentimental feminina podem muito bem terem sido compostas por homens, como no caso de composições famosas de Chico Buarque. Tal expectativa de coerência entre o ator e o papel remete-nos mais uma vez à questão da ilusão - a plateia anseia e exige ser iludida quanto à realidade da representação. A expectativa de coerência entre aparência e maneira nos remete também a duas outras características das representações na vida cotidiana. A primeira delas é a necessidade da realização dramática. Não basta que se execute uma atividade, é preciso que se realce dramaticamente sinais confirmatórios, acentuar a impressão que se deseja transmitir. Não basta que o cantor interprete perfeitamente uma canção, é necessário que a plateia se convença de que ele é arrebatado pelo conteúdo da letra. A segunda característica é a plena compatibilidade que se exige entre pessoa e atividade, como diz Goffman: "a platéia admite muitas vezes que o personagem projetado diante dela é tudo o que há no indivíduo que executa a representação" (GOFFMAN, 1985, p. 51).

O cenário é, evidentemente, outro aspecto de suma importância na performance musical, seja o cenário montado no palco de um show propriamente dito, seja a ambientação dos videoclipes e das fotos que compõem o material publicitário do artista. Ou, toda a gama de cenários procura reforçar os sinais que confirmam a persona do artista. Pense-se a esse respeito a ambientação dos shows de Vinícius de Morais, nos quais o artista ficava todo o tempo simplesmente sentado em sua escrivaninha, com um copo de uísque, expondo a persona de poeta boêmio, que transmitia nas canções suas vivências sentimentais. Ou, então, 
nas produções maximalistas das bandas de rock nas quais se produz uma estética moderna, associada ao uso de muitas máquinas e equipamentos, em que o próprio corpo (os torços masculinos sem camisa e as guitarras manipuladas como uma extensão do falo) é performado como uma das potentes máquinas que se exibem no palco. Todos esses conjuntos de sinais ajudam a enquadrar [to frame] os espaços da execução musical. Casas de concerto, igrejas, bares, porões, são todos espaços que funcionam de modo a dar um quadro de percepção à experiência musical: o que se realiza nas salas de concerto tem muito mais legitimidade, quase que por si só, de ser considerado como música séria, assim como sacra nas igrejas ou "contracultural" em determinados porões. O enquadramento efetuado pelo espaço, por sua vez, é fortemente indicativo do tipo de prática ao qual a música será associada: música para louvar a Deus, música para louvar a própria experiência musical (salas de concerto), para a dança, ou mesmo como elemento catalizador de outras práticas impulsionar as vendas numa loja ou sinalizar a espera numa chamada telefônica.

Auslander argumenta que os artistas se valem do cenário para a performance de suas personas. A prática do Jazz em salas de concerto já é por si só indicativa do esforço por legitimar esse gênero, oriundo dos grupos negros e muitas vezes marginalizados, como a "música clássica americana" (p.310), ao passo que os músicos também se valem do uso de ternos para associar o sentido de respeitabilidade e ascensão social às suas práticas.

\section{O gosto}

A canção, enquanto forma de comunicação, é portadora de representações. Nela temos representações de personae e personagens em narrativas condensadas, miniaturas nas quais organizações sociais mais amplas são representadas. Isso já nos indica que o isolamento da canção enquanto «gramática autônoma» das questões e práticas sociais nas quais está inserida é praticamente impossível, uma vez que o texto depende de atribuições de significado feitas pelo contexto ${ }^{80}$. Vejamos agora em maior detalhe como se dão os nexos entre os sentidos inscritos na canção e os sentidos mobilizados nas práticas sociais, retomando aqui aspectos da teoria de Bourdieu.

Como vimos acima, o arranjo dos códigos expressivos na canção tem o poder de construir personae e situações as quais, por sua vez, estão associadas a imagens sociais de tipos de pessoas e das posições sociais que elas ocupam. Mas o vínculo entre representação

80 É interessante que o próprio Tatit resgata muito do contexto social quando faz as análises semióticas das canções. 
e as relações sociais que ela denota vai muito além do vínculo semântico. As obras de arte, entre elas a canção, estão invariavelmente inseridas numa hierarquia das artes e dos gêneros, que, por sua vez, corresponde a uma hierarquia dos consumidores: das artes mais legítimas, sublimes e sublimadas (que em geral dependem em sua produção dos saberes e condições sociais mais raras) às artes mais comuns, vulgares e vulgarizadas. Homologamente, há também uma hierarquia dos consumidores, daqueles que possuem as competências e condições sociais de apropriação das obras mais raras, competências que não são igualmente distribuídas pois dependem da disposição de certos recursos. Vantagens materiais, como a inserção precoce em um "mundo de pessoas, práticas e objetos cultos" (BOURDIEU, 2007, p.73), a liberdade de poder dedicar seu tempo a coisas e práticas não diretamente ligadas à reprodução material da existência, assim como o acesso prolongado na escola, onde a disposição inculcada pelo afastamento das necessidades primárias se intensifica e se exerce em diferentes campos de exercício são condições desigualmente distribuídas entre as classes sociais. As escolhas em matéria de gosto dependem de condições materiais que variam entre as classes.

Desse modo, a relação entre a representação que as obras realizam e os modos de sua apropriação não é arbitrário. Segundo Bourdieu, a clivagem fundamental na hierarquia das obras e dos consumidores se estabelece entre os gostos de necessidade e os gostos de liberdade: dos gostos que se originam de uma condição marcada por necessidades materiais bem definidas, que comandam o conjunto das escolhas possíveis, e os gostos que se originam da ausência de pressões materiais prementes, em que a diminuição de freios econômicos dá lugar a censuras e interdições simbólicas. $\mathrm{O}$ gosto de liberdade se exerce pela negação do gosto de necessidade, o qual por sua vez também se contrapõe ao primeiro. Clivagem que se estende ao modo de apropriação das obras, não apenas pelas condições exteriores que ela supõe, mas também pelos sistemas de percepção e decodificação das obras que se formam a partir dessas condições.

Mesmo Howard Becker (1988), sociólogo que não privilegia as questões de subordinação e hierarquização social, reconhece a distribuição desigual (e diferencial) dos esquemas de percepção. Becker distingue três públicos. O público amplo, capaz de apreciar apenas as convenções mais gerais da sociedade e as formas artísticas mais tradicionais. No caso da canção popular, trata-se do público das canções que circulam nos meios de comunicação de massa e que se valem largamente dos clichês, das formas estereotipadas. O segundo público é o competente, que, pelo hábito e pelo convívio prolongado com as obras de arte se torna familiarizado com as convenções internas das disciplinas artísticas. Já o 
terceiro público é o dos estudantes que receberam alguma formação em alguma disciplina artística, é o público normalmente afeito a experimentações. Os três grupos participam do mundo da arte como consumidores e aportam apoio material aos artistas, com o dinheiro que gastam no consumo de suas obras.

As convenções inscritas numa obra são reveladoras do estrato social dos compositores, do meio social no qual elas foram produzidas e do público ao qual elas se dirigem. O conceito de convenção refere-se aos métodos habituais de trabalho e às formas de pensamento comuns que subjazem às atividades de cooperação de um grupo de pessoas. As convenções, por facilitarem a comunicação e a cooperação, agem sobre todas as etapas do processo. Elas indicam o material e os procedimentos adequados para traduzir as ideias em uma forma, as formas de aplicação dos procedimentos aos materiais, as dimensões apropriadas das obras de arte, além de regerem as relações entre artista e público. As convenções encarnam-se nos formatos dos materiais, nos equipamentos, nos temas, na formação dos artistas, nas instituições, nas linguagens, nas notações musicais, etc. Mais importante ainda, as convenções, atuando como uma espécie de regra de formalização, são também um meio de comunicação entre artista e público: é precisamente porque ambos possuem conhecimento e experiência comuns das convenções utilizadas que as obras conseguem comunicar emoções àqueles que as procuram.

É por conta disso que as obras não apenas se distinguem entre si, mas também que seus traços formais e estilísticos funcionam como formas de distinguir tipos de indivíduos que se apropriam delas. As diferenças entre os tipos de obra funcionam como um sistema de diferenças homólogo à estrutura social, que se serve delas justamente para marcar as diferenças, sinalizar as distâncias entre classes. Desse modo, não existe escolha ingênua, ou melhor, mesmo a mais ingênua das escolhas possui consequência no jogo social de representações e atribuições hierarquizantes.

Não por acaso as obras de arte e em especial as canções são amplamente utilizadas para fins políticos, para a afirmação de identidades nacionais, étnicas ou de qualquer outro estrato social. Mas também em microssituações, as canções podem assumir função análoga àquela que Goffman designa aos retratos publicitários: a formalização e estereotipia dos comportamentos. Elas oferecem um retrato claro daquilo que está disperso e não formulado na experiência da vida cotidiana, bem como oferecem modelos de comportamento que orientam os espectadores a respeito do seu próprio papel social (GOFFMAN, 1976). Não seria absurdo supor que o estereótipo de comportamento que aparece em canções de amor, canções que falam sobre amizade ou qualquer outro papel social possam servir de modelo e 
orientação para o ouvinte na sua representação de si na vida cotidiana. Portanto, a canção, como forma expressiva, possui a capacidade de definir situações, tanto micro quanto macrossociais, como, por exemplo, na afirmação de identidades nacionais ou na estilização de comportamentos pessoais.

Dado o potencial da canção para servir de modelo e guia em situações macro e micro sociais, podemos também refletir a respeito de sua adequação para funcionar como meio auxiliar na reafirmação expressiva de valores morais de uma comunidade, o papel da música nas cerimônias - característica social que Goffman recupera de Durkheim (GOFFMAN, 1976). Não por acaso, a música é um elemento obrigatório nos mais variados tipos de celebração, tanto religiosas quanto civis. Mas poderíamos também salientar o papel da música não apenas nas grandes cerimônias, onde grandes unidades sociais são celebradas (como por exemplo nos hinos nacionais), como também na celebração de pequenas unidades sociais ou posições sociais particulares. A partir disso, poderíamos compreender a segmentação do público ouvinte a partir da segmentação dos valores sociais ritualisticamente celebrados nos diferentes estilos musicais.

Para justificar melhor esse ponto, aqui deve ser recuperado o argumento de Goffman a respeito de condição, posição e lugar social. Para esse autor:

\footnotetext{
Uma condição, uma posição ou lugar social não são coisas materiais que são possuídas e, em seguida, exibidas; são um modelo de conduta apropriada, coerente, adequada e bem articulada. Representando com facilidade ou falta de jeito, com consciência ou não, com malícia ou boa-fé, nem por isso deixa de ser algo que deva ser encenado e retratado e que precise ser realizado. (GOFFMAN, 1985, p. 74)
}

Portanto, tais atributos sociais são muito mais o resultado de uma performance sustentada diante de uma plateia do que um atributo material que se possua. Podemos traçar um paralelo entre essa noção de Goffman, dos atributos sociais como modelos de uma performance, de uma prática, com a noção bourdieusiana de habitus. Esse conceito pode ser compreendido como a interiorização de relações estruturadas sob a forma de disposições. Uma vez que a incorporação de disposições se dá em um espaço de relações estruturadas, e que tal incorporação tende a funcionar como uma "estrutura estruturante", geradora de futuras disposições e tomadas de posição, podemos dizer que cada posição social será ocupada preferencialmente por um habitus correspondente, e que a performance dramática da posição - a qual, segundo Goffman, é a sua própria matéria constitutiva - pressupõe essa incorporação de disposições que possibilitem ao ator desempenhar o seu papel. As posições 
sociais são, na práxis diária, uma performance, e tal performance exige do ator a incorporação de determinadas disposições, um habitus.

Uma vez que o habitus é atributo determinante na formação do gosto e dos juízos estéticos por conta da incorporação de disposições, podemos agora compreender o papel da música como elemento de celebração ritualística das diferentes posições sociais. A consagração de qualquer estilo musical carrega consigo a consagração das posições sociais e do habitus correspondente dos ocupantes dessa posição. Não é de desprezar o fato de que a música traz consigo toda uma série de disposições corporais, as quais são atributos cruciais nas performances apropriadas às diversas posições sociais. Não podemos esquecer também do aspecto que Goffman denomina de idealização: as posições sociais de maior prestígio são aquelas mais próximas dos valores morais mais prestigiados da sociedade. Consequentemente, o indivíduo tenderá a incorporar e exemplificar na sua prática esses valores socialmente reconhecidos.

Podemos ver assim porque as obras funcionam, em seu conjunto, como um sistema de diferenças que por sua vez funcionam, nas práticas sociais, como marcadores de diferenças sociais. O elemento que faz a mediação entre um universo e outro é o habitus, pois ele funciona ao mesmo tempo como princípio gerador de práticas e como sistema de classificação delas: "descobrir uma coisa de seu gosto é se descobrir, é descobrir o que se quer ('é exatamente o que eu queria'), o que se teria a dizer mas não se sabia como dizer e, por consequência, não se sabia." ${ }^{\text {. }}$. Para Bourdieu, o gosto, entendido como o conjunto de práticas e propriedades de uma pessoa ou grupo, é o produto do encontro entre uma oferta e uma demanda, entre uma espera e a sua realização, entre um habitus do estado incorporado e outro no estado objetivado (BOURDIEU, 1984, p.162). Justamente por conta desse encontro, em que descobrir algo do seu gosto é se descobrir, descobrir o seu próprio habitus incorporado em um estado objetivado, a relação com as obras de arte é vivida de modo tão intenso e sacralizado.

Segundo o autor, o habitus engendra "metáforas práticas", e assim poderíamos compreender tanto as obras como o gosto: metáforas práticas de uma experiência do mundo social, mas uma experiência estruturada a partir das condições objetivas de uma posição específica. Assim, o gosto, entendido como "conjunto de preferências distintivas que se exprime na lógica específica dos subespaços simbólicos” (BOURDIEU, 2007, p.165), opera

\footnotetext{
81 Tradução nossa a partir do francês: “découvrir une chose à son goût, c'est se découvrir, c'est découvrir ce que l'on veut ( «c'est exactement ce que je voulais»), ce que l'on avait à dire et qu'on ne savait pas dire, et que, par conséquent, on ne savait pas." Pierre Bourdieu. La métamorphose des goûts. In: Questions de Sociologie. Paris : Les Éditions Minuit, 1984. p. 162.
} 
a transformação das "diferenças inscritas na ordem física dos corpos à ordem simbólica das distinções significantes" (Idem). O gosto se realiza como "senso das homologias", o senso daquilo que the corresponde nos diferentes campos, senso das afinidades entre pessoas, coisas e práticas que se ligam bem, que combinam.

Mas a hierarquia dos gostos e práticas não possui existência ontológica, ela não é uma coisa nem está totalmente inscrita nas coisas, ela é o resultado sempre parcial e cambiante de disputas. Assim, a realidade social também está parcialmente em disputa nas disputas pelas representações legítimas do mundo social e pelas posições legítimas de tais representações. De modo que as representações feitas pela canção não são desinteressadas; mesmo quando feitas desinteressadamente elas participam das lutas simbólicas em torno da realidade social, luta em torno do Nomos, o que é e quem está habilitado a nomear aquilo que é. Ela participa da luta pela imposição de um modo de viver, a maneira legítima de existir.

A vantagem decisiva da arte em relação à ciência - vantagem desde sempre percebida pela propaganda, mesmo a religiosa ou política - é que uma afirmação, a empresa de persuasão que é toda comunicação, conforme Tatit, é muito mais persuasiva quando vista, ouvida, tocada, cheirada ou experimentada pelo corpo do que quando reconstruída pelo pensamento abstrato. A vantagem da arte é a comunicação direta com o corpo que percebe e sente.

Daí a importância da música e da canção como uma das formas de comunicação mais diretamente físicas, corporais, e que mesmo quando parece estar aquém de um sentido claro, comunica experiências físicas e sociais. Conforme Bourdieu, a mera mimesis corporal é capaz de evocar todo um mundo de sentimentos e experiências, uma metáfora capaz de evocar toda uma relação com o mundo, valores sociais inscritos nas disposições do corpo (BOURDIEU, 2007, p.440).

Isso nos mostra que a canção, como outras formas de representação, não faz apenas um retrato passivo daquilo que ela comunica; ela exerce um papel ativo nas práticas de representação, onde a realidade social está parcialmente em disputa. É interessante reter a associação entre música e corpo, pois gostaríamos de explorar em que medida as representações feitas pela canção estão associadas ao corpo. Talvez não seja exagero dizer que mesmo as canções mais intelectualizadas fazem uso da comunicação corporal, da comunicação direta de estados somáticos. As ideias, valores, críticas sociais, crônicas do cotidiano, confissões passionais e visões de mundo partilhadas pela canção estão sempre encarnadas na voz do intérprete, na voz que enuncia e aproxima inevitavelmente o enunciado 
com o enunciador, o conteúdo com o «eu-aqui-agora» da enunciação por intermédio da debreagem enunciativa, como vimos com Tatit. O receptor também é fisicamente envolvido pela canção, também recebe sensorialmente a sua comunicação, assim como também opera escolhas em matérias de gosto de acordo com estruturas incorporadas. O gosto é sintomático de diferentes relações com o corpo e os sinais socialmente hierarquizados que são atribuídos a essas relações.

A emissão e a recepção da canção perpassam a instância física, de modo que poderíamos dizer que as representações da canção estão associadas à performance corporal de um habitus, um “eu”, um Self. Isso nos remete aos parágrafos finais de $A$ representação do "eu" na vida cotidiana: a própria estrutura do "eu" pode ser considerada segundo o modo como nos arranjamos para executar as representações. Embora geralmente se associe o personagem ao próprio indivíduo que o representa, Goffman sustenta que o "eu" não se

origina do seu possuidor, mas sim da cena inteira de sua ação. A atribuição de um "eu" ao personagem é um produto da cena, um efeito dramático que surge difusamente; o "eu" é uma construção colaborativa. Acreditamos que a canção possa ser considerada como uma das formas de representação e produção do "eu" socialmente situado, inserido numa hierarquia, ao passo que a própria hierarquia é o resultado provisório de disputas em curso: as representações do "eu" procuram persuadir-nos a respeito do que ele é, o que ele deveria ser, qual «Self» deve ser considerado como legítimo e digno de ser representado.

Poder-se-ia argumentar que a canção não possui tamanha importância, que ela é apenas uma forma menor, ligeira, cada vez mais restrita ao consumo subliminar compulsório imposto pelos (cinco mil) autofalantes de supermercados e lojas, e cada vez mais distante de pretensões sérias das artes sérias. Ainda assim, talvez esteja justamente nas persuasões ligeiras, rasteiras e descartáveis do cotidiano que grandes batalhas sejam disputadas.

\section{Conclusão}

Nos capítulos precedentes procuramos estabelecer algumas balizas teóricas para a abordagem da canção, a análise tanto do seu conteúdo, seu sentido, quanto das práticas sociais nas quais ela pode ser mobilizada, justamente por conta das estruturas de sentido que nela estão inscritas. Desse modo, nosso objeto é abordar a canção dentro da perspectiva das práticas de representação, práticas nas quais não há uma apresentação transparente do real, mas sim a sua articulação em uma linguagem. Práticas nas quais a própria realidade está parcialmente em jogo, onde se disputam visões, pontos de vista e classificações da realidade 
social. Representações que são inevitavelmente estratificadas e etratificantes, onde se dramatizam papéis sociais, de modo a criar guias de percepção, displays que procuram fixar um sentido para o jogo de papéis presentes na vida cotidiana.

Nessa perspectiva, procuraremos desenvolver no próximo capítulo um estudo das canções do álbum Clara Crocodilo, de Arrigo Barnabé. Nosso intuito é focalizar a temática da modernidade brasileira, tal como ela é representada nessas canções, assim como quais são as intertextualidades que se podem encontrar: quais outros momentos da música popular brasileira e da música erudita são evocados? Quais deslocamentos, diferenças ou mesmo discrepâncias existem entre as canções de Arrigo Barnabé e aquelas com as quais ele dialoga? Quais diferentes sentidos atribuídos à modernidade nacional podem ser lidos nas canções? Estamos interessados no modo como essas representações apontaram não apenas o Brasil real, mas também as dimensões ideais e até mesmo normativas que estão implicadas nelas: o modo como as canções apontaram direções para o novo, direções do vir-a-ser da ideia/ideal de modernidade brasileira.

Quanto à análise propriamente dita, procederemos a escuta musical dirigindo às canções uma série de perguntas. Do ponto de vista semiótico, questionamos:

1. Qual a forma de junção entre letra e melodia?

2. Qual a cena retratada? Como se constrói a narrativa musical/textual?

3. Quais os recursos linguísticos (deiticos) de construção da cena?

4. Qual o posicionamento do enunciador (debreagem)?

5.Quais são os interlocutores construídos ou presumidos?

6. Quais são os actantes construídos? Como?

7. Qual é o termo complexo articulado? Quais são as suas polaridades?

8. Quais são as marcações fóricas e em quais elementos do texto elas incidem?

Já da perspectiva da canção, enquanto prática social de representação, questionamos: 1. Qual persona e/ou personagem são construídas, qual a fachada pessoal (aparência e maneira)?

2. Qual tipo de interação está sendo proposto ao ouvinte?

3. Quais unidades sociais estão sendo representadas, ritualizadas ou profanadas?

4. Quais tipos de personagens / posições sociais aparecem? 
5. Quais espaços sociais e domínios da prática social estão sendo enquadrados, codificados na canção?

As questões formuladas acima não configuram um questionário fixo a ser respondido ponto por ponto pela escuta musical. O objetivo é fornecer um quadro de questões e referências para a prática da escuta com fins sociológicos. Vejamos como isso funciona na prática. 


\section{Capítulo IV: Escutando Clara}

Partimos neste capítulo para uma análise mais detida do álbum Clara Crocodilo. Ao analisar cada canção, tem-se em mente o conjunto de questões elaboradas no capítulo anterior, embora nos guardemos relativa liberdade para enfatizar os pontos que nos parecem mais relevantes em cada caso concreto. Mas devemos, em primeiro lugar, fazer algumas observações a respeito da história da produção do álbum e da construção das canções. Clara Crocodilo é fruto de um longo processo; cerca de sete anos (de 1972 a 1979) foram necessários para a composição das canções, muito embora grande parte desse tempo tenha sido usado para a criação das letras (Arrigo fala em criação da parte "cenográfica” do álbum), ao passo que a parte musical já estava pronta em 1973. Os primeiros passos foram dados ao lado do colega Mario Lúcio Cortes, e o processo deixa transparecer a ambição de Arrigo de lançar todas as suas referências musicais, estéticas e literárias na construção do álbum. Do lado da música erudita, Béla Bartók e Igor Stravinsky foram referências para Arrigo no uso do ritmo, e como salientaremos, de fato é perceptível a influência, sobretudo do primeiro, no modo de atacar as teclas do piano. Se Chopin dizia que é preciso esquecer que o piano é um instrumento feito de martelos, Bartók parece querer nos lembrar exatamente disso, ao passo que em Arrigo podemos ouvir o ataque às teclas como se o piano fosse uma bateria, enfatizando o lado percussivo do toque e, por sua vez, um gesto musical violento, agressivo. Também das vanguardas musicais eruditas do século XX, há no disco referências à música eletroacústica de Stockhausen (a abertura da última faixa é um excerto dele) e, é claro, aos procedimentos seriais e atonais desenvolvidos por Arnold Schönberg.

Já uma das numerosas referências provenientes da música popular veio através do livro O balanço da bossa de Augusto de Campos. Segundo Arrigo foi, em primeiro lugar, a noção de uma "linha evolutiva" da música popular, discutida nesse livro, que o instigou a criar uma obra a qual se referia e se situava em relação ao desenvolvimento da linguagem da canção popular, principalmente no tocante ao diálogo entre erudito e popular que já havia sido feito em outros momentos. Se houve um momento da canção popular brasileira a partir do qual Arrigo situou sua atuação musical, este é sem dúvida a tropicália. Já vimos como, a partir de mudanças introduzidas pela tropicália, o compositor acreditou que o próximo passo seria alterar a própria gramática musical da canção, fazendo chegar a ela as transformações que haviam ocorrido na música erudita ao longo do século XX. Também foi a tropicália, mas aqui sobretudo o trabalho de arranjadores como Rogério Duprat e Júlio Medaglia, que lhe sugeriu formas possíveis de articular a linguagem musical erudita com a canção. Já nesse 
ponto se nota a intensão vanguardista do compositor. Por exemplo, na composição da canção Clara Crocodilo (a última do álbum, mas a primeira a ser composta): o primeiro passo foi a escolha da formula de compasso, $7 / 4$, escolhido justamente por ser uma formula raramente usada. Na criação das linhas melódicas, o procedimento serial foi a fórmula escolhida, na qual o compositor trabalha com uma serie pré-definida de notas e a partir disso organiza o material musical com os mais variados tipos de permutação: inversão, retrogradação e transposição (CAVAZZOTI, 2000, p. 9).

Curioso notar que um dos primeiros compositores a se valer dessas técnicas (inversão, retrogradação, etc.) para a música foi Bach, o grande codificador do sistema tonal. Sendo ele um dos pioneiros da linguagem tonal, valeu-se desses meios para dar coesão à nova linguagem, ainda pouco estruturada (o uso dessas técnicas pode ser fartamente observado nas fugas). Após séculos de desenvolvimento harmônico, esses recursos voltam para dar coesão ao sistema que criou a morte e a superação do tonalismo, o dodecafonismo. Retornando a Arrigo, é também curioso que em várias entrevistas ele insista em sublinhar que, embora a aparência de caos, na sua música nada é arbitrário, tudo foi criação planejada. De fato, pode-se imaginar que o ouvinte desacostumado à música atonal creia que ela é apenas caos sonoro, quando na verdade a ela subjazem muitos dos mesmos princípios de estruturação que regiam a época do Barroco.

Também a respeito do modo de estruturação das canções, o compositor salienta que, inspirado pela leitura de $A$ obra aberta de Umberto Eco, organizou as canções em módulos que se encaixam um nos outros e poderiam ser deslocados e rearranjados livremente (ao ver execuções ao vivo do álbum, bem como regravações - em especial Ao vivo em porto -, percebe-se que Arrigo de fato brinca com os módulos, buscando novas formas de encaixe). A organização em módulos traz questões interessantes a respeito da coexistência entre linguagem erudita e canção no álbum. Pois se o uso de módulos soa como algo erudito, é justamente esse o ponto da articulação da linguagem erudita com a canção popular. Talvez a principal diferença do ponto de vista estritamente musical entre canção e música erudita seja que a última, historicamente, estrutura-se com a exposição de temas e o seu desenvolvimento (desnecessário dizer que as vanguardas do século XX esforçaram-se por desconstruir também este princípio). Pense-se na famosíssima quinta sinfonia de Beethoven, onde da exposição do tema logo no início segue um imenso desenvolvimento. Já a canção é uma forma circular, na qual as partes (A, B, C ...) são trabalhadas ciclicamente, deixando de lado o pensamento linear de exposição e desenvolvimento e dando lugar à circularidadeAo trabalhar com módulos, Arrigo articula as duas linguagens, pois se o conteúdo dos 
módulos é construído com técnica erudita, a articulação modular segue a maneira da canção de articular as partes em um todo circular. Além disso, é o próprio Arrigo quem nos diz que o uso da repetição (e veremos com as canções são de fato repetitivas) dos módulos aproxima suas canções da linguagem popular ${ }^{82}$. Mas é necessário, antes de tudo, reforçar que o que foi dito aqui não tem um valor causal: não é simplesmente o uso de módulos ou o tipo de articulação entre eles que faz de uma peça per se uma canção popular, assim como não é simplesmente o desenvolvimento de uma ideia musical que faz uma peça tornar-se automaticamente erudita (compositores eruditos como Debussy, Ravel e Stockhausen não trabalharam dessa forma). Estamos afirmando apenas que neste caso concreto, a solução encontrada por Arrigo Barnabé para equacionar música serial com a canção foi criar módulos, de modo que o conteúdo dos módulos está estruturado com procedimentos seriais, mas os módulos entre si articulam-se como uma canção.

Diga-se também, a própria criação do nome do álbum é ilustrativa do processo de permutação que organiza as melodias no interior dos módulos. O nome foi criado a partir da leitura do poema Aura Amara, traduzido por Augusto de Campos do trovador Arnaut Daniel $(1180-1210 ?)$ :

Aura amara
branqueia os bosques, car-
come a cor
da espessa folhagem.
Os
bicos
dos passarinhos
ficam mudos,
pares
e ímpares.
E eu sofro a sorte:
dizer louvor
em verso
só por aquela
que me lançou do alto
abaixo, em dor
— má dama que me doma.

${ }^{82}$ Em depoimento disponível em: ONCOTO Entrevista com Arrigo Barnabe. São Paulo: Jorge Mautner, 2014. P\&B. Disponível em: <https://www.youtube.com/watch?v=weXCjzoCfUA>. Acesso em: 08 maio 2018. 
Foi a partir desse poema que lhe surgiu a ideia de um nome com economia de letras e que condensasse a mesma antítese, presente no poema, de significados opostos com sons próximos. Mas devemos ressaltar também que o álbum foi um empreendimento coletivo. Arrigo sublinha o importante papel de Regina Porto na gravação do álbum (foi a gravação dela das canções ao piano que serviram de referência para a gravação de todo o álbum). Destacado também o papel de Itamar Assumpção, responsável pelo baixo elétrico, de Tonho Penhasco na guitarra, dos metais, de Paulo Barnabé (irmão mais novo de Arrigo) na bateria, de Bozzo Barreti no sintetizador, e do coro feminino formado por Vânia Bastos, Suzanna Salles e Neuza Pinheiro. A formação da banda, portanto, pouco difere daquela de outros grupos populares, o que vai de acordo à proposta de Arrigo de fazer algo novo, mas que pudesse ser tocado com instrumentos populares. Escutemos então detalhadamente cada uma das canções.

1. Acapulco Drive in

Boca da noite

Boquinha de gata

Chupando, mordendo

Bala de conhaque

Colored

Color na garoa

Dentro do maverick

Cheirando a jasmim

Passa o coroa

Fazendo sinal

Psiu, psiu, ei

Psiu, psiu, ei, princesa

Você já foi ao play center?

Hum, mas que idéia extravagante...

Então que tal uma tela?

Ah, essa não

Topas um drinque num drive-in?

Meu preço é alto, viu bem

Por você eu faço tudo

Por você eu perco o juízo 


\author{
[Interlúdio musical] \\ Tire, quero tua pele parda \\ Lábios de carmim \\ Brr... tentação nua \\ Empina o volante \\ No zíper, a surpresa que já tarda \\ Calcinha imitando \\ Pele de leoparda \\ Mas que gracinha \\ Acapulco drive-in
}

A divisão em cores mostra os versos que são cantados pelas vozes femininas, em vermelho, e masculinas, em preto. Reforçamos esse elemento pois a divisão sexual das vozes é um dos binômios mais importantes em todas as canções do disco. É importante notar também que as vozes femininas são sempre em conjunto, ao passo que a voz masculina é solo. Os espaços evidenciam os blocos/módulos nos quais a canção se divide. Os primeiros blocos se repetem 2 e 3 respectivamente, ao passo que nos seguintes a narrativa se torna mais linear, narrando a história quase como oralmente, quase sem repetições ou outros recursos que poderiam complicar a evolução da narrativa.

As partes em negrito são as únicas em que a passionalização entra em cena. Nas outras, predomina a tematização, ao mesmo tempo em que o ajuste entre letra e melodia é quase totalmente musicalizado, chegando mesmo a ofuscar qualquer vestígio de fala, de figurativização. No entanto, conforme sublinha Tatit, as canções geralmente se equilibram, convocando traços do modelo oposto. Isso ocorre no terceiro bloco em que a figurativização domina completamente, chegando mesmo a interromper todos os outros instrumentos enquanto é enunciado o diálogo como fala crua. Na verdade, isso ocorre em todos os blocos. Há pausas, "breaks", em que uma frase é dita como fala crua. A estrutura de cada bloco se repete na macroestrutura da canção: variação entre voz conduzida pela tematização (as figuras rítmicas são muito bem delineadas, e saltam aos ouvidos também por apresentarem divisões rítmicas complexas, incomuns) e pela musicalização (voz soa quase plenamente como instrumento), e a voz enunciada como fala crua, sem mesmo acompanhamento musical.

As primeiras estrofes, que se repetem, constroem a ambientação da cena: é definido o espaço (boca da noite) bem como uma das personagens, aqui definida metonimicamente 
como uma boca (boquinha de gata), boca a qual, por sua vez, é apresentada com dois verbos no gerúndio: chupando e mordendo. Verbos que já possuem por si mesmos uma forte conotação sexual, levemente suavizadas quando o objeto dessas ações é uma bala. O fato da bala ser de conhaque também já evoca conotações interessantes, não é uma bala simplesmente doce, açucarada, como se esperaria de uma bala Tutti frutti, mas sim uma bala de conhaque, de sabor amargo (sabor de veneno). Contudo, ainda assim é uma bala, consumida, saboreada, mordida e chupada, já trazendo à baila a figura da ambiguidade, que permeia todo o álbum. Talvez seja esse o tema principal.

O segundo verso começa com um dêitico espacial, "dentro do maverick", e a segunda personagem, caracterizada também primeiramente por um atributo físico, o cheiro, atributo que convoca a noção da proximidade espacial, e também fortemente corporal. Novamente, a figura da ambiguidade: o cheiro de jasmim, o perfume, seria ele um odor agradável ou excessivo? A contradição entre o automóvel esportivo, a ideia de potência e juventude associada a ele contrasta com o adjetivo "coroa": o tragicômico da tentativa de mascarar, de aparentar o que não é, a discrepância na fachada pessoal da personagem e o efeito de ridículo que isso provoca. Com esses dois blocos caracteriza-se a cena da abordagem de um «cliente» e da prostituta, construindo o cenário no qual se desenrola o diálogo/negociação que vem a seguir.

Importante observar que as vozes femininas se encarregam das partes musicalizadas, ao passo que a voz masculina é sempre figurativizada, com exceção do verso: "a surpresa que já tarda”, um dos poucos onde predomina a passionalização. Importante também que a voz de Arrigo Barnabé só aparece de modo muito fugaz, fazendo comentários em segundo plano. É importante desvendar quem é a persona incorporada na voz de Barnabé no disco. As vozes do coro feminino assim como a voz masculina são narradores que descrevem a cena, mas também assumem a posição de personagens. As únicas passagens passionalizadas, ou seja, sob o signo do sentimental, são cantadas em tom de blague, ironicamente, com a impostação de voz dos cantores românticos da era da rádio (Orlando Silva, que virá a seguir).

$\mathrm{Na}$ terceira estrofe temos o início do diálogo/negociação entre as duas personagens. Interessante notar a sequência de lugares sugeridos pelo personagem coroa: play center, cinema e drive-in. Espaços de lazer, de diversões, que conotam um tipo bem específico de consumo, assim como um "clima" bem específico do moderno, da cidade moderna, da cidade grande e o seu leque de opções de lazer, mas que são todos espécies de paraísos artificiais, de diversões eletrônicas. No final aparece a expressão "perder o juízo", já trazendo à baila conotações da animalidade, do instintivo, da ausência das qualidades 
"civilizadas" e que por sua vez também se dirige à animalidade do ato sexual, vide o elemento visual trazido: a calcinha em pele de leoparda. A canção termina com a construção desse signo visual: a calcinha que imita pele de leoparda. Para além da conotação de animalidade que se liga ao ato sexual (daí também a sensação de blague que recai sobre as partes passionalizadas: a sensação de estranhamento quando há remissão ao romantismo numa cena de sexo entre a prostituta e o seu freguês), a imitação, a noção de simulacro e de artificialidade construída no verso "calcinha imitando pele de leoparda" é algo sugestivo e antecipa muitos temas que serão desenvolvidos nas canções seguintes. A artificialidade da calcinha é consoante com a artificialidade do encontro sexual pago, consoante também com a artificialidade dos espaços sugeridos: o parque de diversões, o cinema e o drive-in. Espaços de projeções de imagens artificias.

Do ponto de vista das personagens, podemos distinguir dois programas narrativos distintos, mas não irreconciliáveis. Do ponto de vista do "coroa", temos um projeto que se articula no termo complexo conjunção sexual e disjunção sexual. Já do da prostituta (a "princesa") o termo é a conjunção monetária e a disjunção monetária: que seu objeto de valor é o dinheiro se explicita no verso "meu preço é alto, viu, bem". A conciliação desses dois projetos narrativos, dessas duas buscas por objetos de valor é literalmente negociada entre as personagens. O "coroa" tenta persuadir a princesa a aceitar seu convite. Os termos de negociação são principalmente os espaços sugeridos, duas vezes negados pela princesa, ao passo que a sua contrapartida monetária é prontamente atendida pelo coroa. Uma vez que a cena se transfere para o drive-in, os dois programas narrativos já estão perfeitamente ajustados entre si. Mas o coroa, que antes se mostrava inclinado a se submeter aos termos de sua princesa, agora ocupa a posição dominante, a quem é dado dizer os verbos no imperativo: tire e quero.

Interessante notar que na canção temos personagens bem delineadas, numa cena muito clara, com projetos narrativos muito explícitos. Se, por um lado, os elementos visuais como a boquinha de gata, a bala de conhaque, o maverick e a calcinha de leoparda dão margens a muitos sentidos figurados (conotações), a narrativa em si mesma é clara, deixa pouca margem para sentidos implícitos. Já podemos começar a perceber a proximidade com a linguagem dos quadrinhos, uma linguagem de traços expressivos exagerados, que tende ao caricatural: aparência e maneira dos personagens são realizadas com traços exacerbados. No entanto, a persona do artista Arrigo Barnabé praticamente não aparece, sua voz é ouvida apenas em comentários fugidios. 
Se, como disse Goffman, as unidades sociais de maior prestígio são aquelas mais próximas do centro sagrado de uma sociedade, mais próxima dos valores sagrados, e, como de modo análogo aponta Bourdieu, a promoção social é comumente vivida como uma promoção ontológica à um tipo superior de humanidade, nessa canção temos o inverso, o oposto: as posições e qualidades sociais mais indesejáveis são retratadas (prostituição e velhice) em espaços sociais igualmente desprestigiados. Mas seria mesmo indesejável? Retomando noção semiótica de que o objeto é sempre objeto de desejo, ao passo que o indesejável é abjeto, é repulsivo, vemos que a canção de Arrigo logra misturar essas noções, tornar ambíguas a desejabilidade ou indesejabilidade dos actantes. É o coroa desejável? As negações sucessivas da prostituta/princesa bem como a alusão ao preço alto dão a entender que não, mas ele é mesmo assim portador de qualidades (disposição de pagar, o dinheiro) suficientemente eloquentes para convencer a princesa. Seria a prostituta desejável? A disposição e insistência do coroa para obtê-la dão a entender que sim, mas (extrapolando a análise meramente textual) ela é menos parceira do que objeto de consumo sexual. Os espaços sugeridos para a realização do coito são sugestivos da avaliação negativa que ele próprio tem do ato que deseja consumar, o tipo de prática feita às escondidas, às escuras, furtivamente, no escuro de um cinema ou drive-in. Ele não a convida, por exemplo, para um restaurante, para um baile ou para a sua casa, espaços destinados aos encontros legítimos.

Essa ambiguidade entre desejável e indesejável, objeto e abjeto estende-se não somente aos personagens, mas também aos objetos que compõem o cenário: a bala doce/amarga, o automóvel moderno/brega (sobretudo por conta do ocupante), os espaços ao mesmo tempo modernos e kitsch.

\title{
2. Orgasmo Total
}

\author{
Sim, eu sei, todo mundo que vai num Drive in \\ Espera conseguir, pelo menos um, \\ Orgasmo total
}

Você me falou assim:

Vem, bebe, sirva-se de mim

E a luz se apagou

Então eu senti na pele

Você, seu corpo em febre

Juro que eu nunca imaginei, amor

Ah, ah, ah, ahhhh 


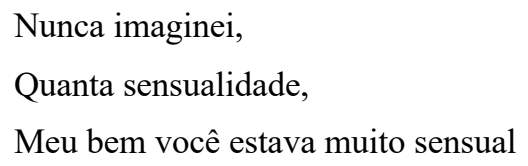

Juro que eu nunca imaginei, amor

Nunca, nunca

Ah, ah, ah, ahhhh

Quanta eletricidade

\author{
Você estava mesmo fatal \\ E parecia louca \\ Como um animal \\ Dizendo aqueles palavrões, gemendo \\ Pedindo mais, mais \\ Até chegarmos ao orgasmo total \\ Orgasmo total \\ Até chegarmos ao orgasmo total \\ [Segunda parte] Trazido pelo reembolso postal \\ Você também pode \\ ser como eles. Você também pode conseguir \\ O seu orgasmo total. Peça já pela caixa postal 6969, \\ O seu exemplar de "o orgasmo ao alcance \\ de todos" E um feliz orgasmo, \\ Ouvinte
}

\author{
Até chegarmos ao orgasmo total \\ Orgasmo total \\ Trazido pelo reembolso postal \\ Orgasmo postal
}

Para delinear a forma de junção de melodia e letra nessa canção, devemos indicar a existência de duas vozes que se distinguem de modo evidente: a voz masculina e a voz feminina. Na verdade, vozes femininas que cantam em uníssono, e que justamente por isso, podemos argumentar que essas vozes comprimidas representam uma só persona e personagem na cena da canção. A voz masculina de Arrigo Barnabé surge na primeira estrofe como uma espécie de narrador que, no momento em que enuncia, está de alguma forma distante da cena que começa logo na próxima estrofe (distanciamento temporal e espacial). 
A voz enuncia o texto sem canto, fala cotidiana pura, estamos no terreno da figurativização. Tem-se a impressão de que essa voz fala diretamente ao enunciatário da comunicação principal (a comunicação entre cantor-ouvinte), nós mesmos. A marca da oralidade vem pela expressão «sim, eu sei» que abre a canção, a qual introduz a percepção de um diálogo: uma concessão ou resposta que o enunciador dá, não sabemos a quem ou em resposta a que.

A mesma voz abre a segunda estrofe, mas a entoação aqui marca uma ruptura com a fala anterior. Não apenas o dêitico vocativo "você" indica a projeção no texto de uma outra situação, mas também o canto ao estilo "Sprechgesang" e a emissão de voz gutural ("tensoestrangulada") marcam a passagem da mesma voz a uma outra personagem. O verbo no passado "falou" instaura um outro tempo-espaço da ação, embora a comunicação permaneça entre o eu e o tu. Mas, então, fica claro que estamos diante dos personagens da canção anterior, o coroa e a princesa (cliente e prostituta) que dão sequência à cena anterior, consumado o programa no Drive-in. A diferença fundamental aqui é que a voz do enunciador não é mais o narrador observador da primeira estrofe, mas uma das personagens da cena (o coroa) retratada enquanto memória reconstruída pelo diálogo. Duas importantes observações sobre a voz masculina: 1. Na primeira estrofe - quando se abre a cena no Drive-in, a voz do narrador vai adquirindo progressivamente a emissão gutural "tenso-estrangulada", incorporando-a definitivamente ao entoar o verso "seu corpo em febre". Esse "crescendo" da tensão na voz dá indícios do envolvimento progressivo do narrador com a cena que recupera na memória, assim como da excitação sexual crescente. Diga-se de passagem, essa emissão de voz (que aparece aqui em primeiro plano pela primeira vez) tornar-se-á a marca registrada de Arrigo Barnabé, sua persona musical ao longo de toda a sua carreira. 2. A segunda diz respeito ao uso da técnica "Sprechgesang": a entoação segue as notas da série atonal tocada ao piano (piano e baixo a partir da $3^{\text {a }}$ estrofe), embora procure resguardar alguma semelhança com a fala. A série atonal já é algo que por si só causa estranhamento nos ouvintes desacostumados à música dodecafônica - ao ouvir o canto que paradoxalmente se aproxima da fala ao mesmo tempo que perfaz uma melodia atonal, obtém-se o efeito de estranhamento duplo da maneira de falar e cantar ao mesmo tempo plausíveis e improváveis. Uma estranha familiaridade com algo estranhamente familiar.

Desde a primeira estrofe, a voz masculina é acompanhada por gemidos e sussurros femininos. A voz feminina (que não representa a persona da prostituta, uma vez que enuncia no relato frases que se dirigem a ela) entra definitivamente em cena somente no primeiro verso da terceira estrofe, cantando em registro hiperagudo, incomum para a canção popular. O contraste masculino/feminino, embora ambas as vozes incorporem o mesmo personagem, 
se dá na relação grave/agudo. Além disso, a entoação das vozes femininas apresenta um padrão rítmico muito saliente (estamos no terreno da tematização). Tudo na voz feminina apontaria para a descaracterização da fala cotidiana - o registro extremamente agudo, o acompanhamento das notas da mão direita do piano, a marcação rítmica saliente - não fosse o tonema descendente, plenamente perceptível, que nos faz ouvir a entoação típica de uma frase afirmativa. Também apesar do estranhamento causado pelos elementos destacados, há uma conotação explicitamente sexual do timbre da voz, tanto por conta da emissão de gemidos quando pelos glissandos descendentes que também remetem ao prazer sexual.

O estranhamento apesar da familiaridade, ou a familiaridade apesar do estranhamento com a voz feminina chega ao paroxismo quando ela entoa a última estrofe (a qual funciona como uma espécie de refrão na canção): repetição incessante da mesma figura rítmica, registro hiperagudo (que se aproxima de ruídos eletrônicos) e repetição também do jogo de palavras em torno da homofonia entre total/postal. Este jogo de palavras exprime de forma indireta o que a voz masculina explicita de modo irônico e sarcástico: a cena sexual se trasveste de anúncio comercial radiofônico, o sexo animal, o orgasmo total é vendido pelo reembolso postal. Assim, o relato da cena de sexo é emoldurado pelas intervenções de um locutor, sendo que na penúltima estrofe estamos inequivocamente diante de um locutor radiofônico que se dirige diretamente, em suas últimas palavras a "você", nós, ouvintes. A canção apresenta-nos a cena do ato sexual entre a prostituta e o freguês, o coroa e sua princesa, relato que desliza para um anúncio comercial, recolocando desse modo a relação sexo/dinheiro que já está implicada na cena de prostituição: tanto no jogo de palavras da voz feminina, quando na prosa da voz masculina.

Interessante notar como a cena é retratada do ponto de vista musical. A canção começa com uma série atonal tocada ao piano, acompanhada de efeitos sonoros que dão uma atmosfera noturna, ou até mesmo alienígena. Os gemidos e sussurros da voz feminina surgem junto à voz masculina, ao passo que o arranjo permanece restrito à voz e piano até a entrada do canto feminino na terceira estrofe "juro que eu nunca imaginei", quando entram o baixo e a bateria (note-se a bela passagem da frase musical do piano para o baixo). A entrada de novos instrumentos junto ao registro hiperagudo das vozes femininas aumenta consideravelmente a tessitura e o "corpo" sonoro da canção. Essa transição opera um corte de modo eficaz, no sentido cinematográfico, do monólogo da voz masculina em um tempoespaço posterior à cena para o retorno ao Drive-in., como se a ampliação da paisagem sonoro correspondesse à ampliação dos elementos visuais da cena. No último verso da quinta estrofe "Dizendo aqueles palavrões, gemendo" a mão direita executa uma sequência de notas que 
formarão o ostinato que acompanha o refrão "Orgasmo total/Até chegarmos ao orgasmo total", ostinato de notas agudas cantado em uníssimo pelas vozes femininas. O refrão é repetido quatro vezes até uma pausa de todos os instrumentos, menos o piano que retoma a série atonal inicial, reiniciando a canção com sutis alterações, principalmente na dinâmica do piano que ataca as notas com muito mais força. Outra diferença é a entrada dos instrumentos de sopro na retomada do refrão após a locução/anúncio (que só aparece na segunda vez). O refrão repete-se várias vezes, com todos os instrumentos tocando em fortíssimo: abundância de sons, ruídos e principalmente a repetição incessante do ostinato possivelmente causam desconforto no ouvinte, sugerindo um ambiente de estímulos excessivos, de artificialidade e saturação, chegando mesmo ao caos e sufocamento pelo excesso.

A narrativa da canção constrói um jogo relativamente complexo entre o que é dito, quem fala, os espaços e elementos visuais implicados. Da primeira fala do emissor, um fragmento de diálogo não se sabe ao certo com quem, passa-se ao relato de um evento passado dirigido ora a "você" ouvinte, ora a "você" prostituta. Mas nada impede que eles sejam ouvidos ao mesmo tempo. Trata-se do sincretismo típico da canção: o "você" pode sempre ser percebido como implicando ao mesmo tempo a personagem da canção e o ouvinte. A menção ao Drive-in na primeira estrofe localiza a cena e remete aos personagens da canção anterior, ainda que nesse momento apenas a persona masculina fale. Interessante que nesse caso até mesmo as vozes femininas falem pela persona masculina.

O relato é construído como recuperação de uma memória (trata-se de uma estratégia da "ilusão entoativa", proporcionar ao ouvinte a ilusão de que ele está diante de uma situação de comunicação real). Logo após o verso que introduz a cena, a fala da personagem prostituta é feita no discurso indireto, e percebe-se uma inversão da relação que se estabeleceu na canção anterior. Se antes o freguês tentava convencer a prostituta a fazer o programa ao passo que ela o rejeitou duas vezes, sendo que na terceira ela apenas implicitamente aceita ao adverti-lo que seu preço é alto, agora ela se oferece enquanto objeto a ser consumido, embora ainda reja a ação no imperativo "vem, bebe, sirva-se de mim". Volta-se então ao discurso direto e a isotopia do sexo é construída com metáforas visuais e sensórias: a luz se apaga, sente-se na pele o corpo em febre. O momento de conjunção entre os personagens é construído, na linha entoativa, como de costume, pela tematização. As vozes femininas asseveram "Juro que eu nunca imaginei” através de figuras rítmicas bem delineadas, não há percurso de busca na linha entoativa, mas sim um movimento cíclico de conjunção. $O$ movimento conjuntivo é acompanhado por gemidos e exclamações que reforçam a isotopia 
do sexo: sensualidade, eletricidade. Que "eletricidade" seja usada como adjetivo para caracterizar a intensidade da excitação sexual é algo significativo dentro da representação global da cidade feita por Arrigo Barnabé ao longo de todo o álbum, e não por acaso a canção seguinte se chama "diversões eletrônicas". Pois se eletricidade pode conotar a intensidade de sensações físicas e, no caso, eróticas, ela também remete à máquina, ao eletrônico, ao artificial, ao autômato. Não se esqueça que o espaço da cena é o Drive-In, espaço que implica uma forma muito peculiar de interação entre homem e máquina na chave do prazer e do consumo: a projeção de imagens artificiais assistidas no isolamento e privacidade de um automóvel. Mas em oposição à conotação de máquina, a mulher é qualificada como mortífera, irracional, animalesca: "fatal", "louca", "animal”, de cuja intensificação chega-se ao ápice, o orgasmo.

O surgimento da locução radiofônica logo após o ápice reforça uma das teses de Tatit. Trata-se do entendimento de que a canção tende a evitar os extremos em seu campo de oscilação. Quando a permanência em um de seus polos ameaça saturá-la, ela move-se em direção ao polo oposto, seja na forma de expressão, na forma de conteúdo ou em ambas. Ao chegarmos ao orgasmo-refrão, chegamos ao ápice da repetição das formas temáticas, ao ápice do campo da tessitura com as vozes agudas assim como ao ápice da conjunção entre os actantes. Desliza-se então imediatamente para a figurativização, a fala cotidiana na locução/anúncio. Instaura-se aqui um distanciamento tanto da conjunção dos personagens quanto do ouvinte em relação ao orgasmo. Nesse anúncio algo irônico e sarcástico, pressupõe-se que o ouvinte esteja distante do orgasmo e anuncia-se a possibilidade de obtêlo comercialmente, numa relação mediatizada, pelo rádio, telefone, caixa postal.

Temos então uma canção onde a euforia prevalece sobre a disforia, onde a conjunção entre actantes prevalece sobre a disjunção e onde recursos linguísticos são utilizados para dar credibilidade à ilusão enunciativa. Ainda assim, e aqui tocamos mais uma vez naquilo é um dos traços mais importantes desse álbum, o autor logra sempre introduzir a ambiguidade nos marcadores fóricos, desejável/indesejável, atrativo/repulsivo. Pois se a conjunção sexual é aparentemente eufórica, a repetição da série atonal e os hiperagudos das vozes femininas produzem desconforto, assim como a entoação da voz gutural masculina remetem a sensações desagradáveis de ameaça, medo, angústia. Não seria exagero dizer que a cena como um todo tende para uma estética do grotesco, o que é apenas reforçado pelo anúncio radiofônico e suas alusões pornográficas.

No que se refere aos personagens e persona da canção, o mais importante é notar a transformação que ocorre na persona incorporada pela voz de Arrigo Barnabé. Pois se na 
primeira canção ela só aparecia em comentários incidentais, nesta ela abre a canção, narra a cena e incorpora uma de suas personagens. Progressivamente ela adquire a emissão "tensoestrangulada" que se tornará a marca registrada do compositor. Mas quem é o personagem e a persona que se encarnam nessa voz? Por que ela se dirige diretamente ao ouvinte e que tipo de relação ela quer entreter com ele? Isso ficará claro apenas ao longo o álbum.

3. Diversões Eletrônicas

$\mathrm{Su}, \mathrm{su}$, antro sujo

Só você não viu

Mas ela entrou, entrou com tudo

Naquele antro, naquele antro sujo

Você nunca imaginou, mas eu vi

No luminoso estava escrito

«Diversões eletrônicas» $(3 \mathrm{x})$

Só você não viu

Mas ela entrou, entrou com tudo

Naquele antro, naquele antro imundo

Você nunca imaginou, mas eu vi

No luminoso estava escrito

«Diversões eletrônicas» $(2 \mathrm{x})$

Era um balcão de bar de fórmica vermelha (4x)

E você ali, naquele balcão

- de quê?

De fórmica vermelha

Chorando, embriagado, pedia:

Garçon, mais um

Gin tônica

Mas ele te avisou:

Você já bebeu muito, já bebeu demais

Vai pra casa, moleque

E você foi, cambaleando

Até... até o telefone

Telefone público... blim, blim, blim

E discou, discou, discou

Novamente o mesmo número... número $(2 \mathrm{x})$ 
Sim, eu sei bem.

Você caiu desesperado por ela

Toda noite na janela, vendo a cidade a luzir

Nesses delírios nervosos, dos anúncios luminosos

Que são a vida a mentir

E veio se entregar à bebida aqui neste balcão de bar

Fazendo círculos num copo de gin tônica

Olhando a fórmica vermelha

Você me dá dó

Sim meu amigo

Pena

No fliperama, ela entregava toda sua grana

- pra quem?

Prum boy, prum boyzinho sacana

Ex-motorista de autorama

Agora viciado nessas máquinas de corrida... viciado

Que tinha ganho fama pela sua perícia

Como volante

E pelo tratamento violento que dispensava

A suas amantes

Mas também, ela era feroz.

Tanto que ele deixou a marca dos dentes dela no braço,

Pra depois mostrar pro delegado.

Se acaso ela for se queixar das surras que levou,

Por causa de um ciúme incontrolado.

Depois, quando clareou

E eles foram pro hotel

Ela viu um bêbado jogado no chão

E sorriu perversa

A canção "Diversões Eletrônicas" é a peça central do álbum Clara Crocodilo. Foi com essa canção que Arrigo Barnabé, em maio de 1979, recebeu o prêmio de melhor música no Primeiro Festival Universitário da TV Cultura de São Paulo-, fazendo seu nome circular na imprensa como a grande novidade da música popular brasileira. O que nos interessa neste momento é o modo de construção da cena da canção, provavelmente a mais emblemática de toda a carreira do compositor. A forma de junção de melodia e letra, assim como a divisão entre vozes masculinas e femininas seguem o mesmo padrão da canção anterior. As vozes 
femininas operam num registro hiperagudo, chegando mesmo a evocar ruídos eletrônicos, o que é sem dúvida um recurso estético para a caracterização da cena no "antro sujo" de diversões eletrônicas. A voz masculina, por sua vez, retoma a emissão gutural "tenso estrangulada" (MACHADO, 2007, p. 86) característica da persona Arrigo Barnabé. Também em continuidade com a canção anterior, tanto as vozes femininas quanto a voz masculina sincretizam na canção uma mesma posição de narração, o narrador que, mais uma vez, reconstrói no seu relato uma cena já ocorrida. Interessante notar, porém, que diferente das duas primeiras canções, já não é mais evidente qual a parte da persona narrador na cena construída pela canção. Ou seja, ela não chega a se constituir plenamente como uma personagem da ação narrada, mas apenas retrata os fatos como uma testemunha ocular. Toda a canção é construída pela referência ao ato de ver: "só você não viu", "mas eu vi”, "ela viu" são expressões que se repetem várias vezes, assim como a descrição do que foi visto.

A ênfase na observação recai muito menos na descrição de ações em um programa narrativo do que na construção visual de objetos e cenários: o antro sujo, o luminoso, o balcão de fórmica vermelha (enunciado inúmeras vezes durante a canção), o fliperama, a imagem de um bêbado jogado no chão. Já a ação propriamente dita é construída de forma muito sintética: uma personagem feminina ("ela") entra no antro sujo chamado "Diversões Eletrônicas". O verso "era um balcão de bar de fórmica vermelha", que se repete quatro vezes como linha principal e depois segue repetido muitas vezes em backing vocal produz o recurso de "corte" no sentido cinematográfico. Introduz-se então uma cena que transcorre paralelamente. Um personagem masculino ("você", mas também referido como "moleque") bebe gin tônica em um balcão de bar (de fórmica...?). O breve diálogo com o garçom e a descrição do seu andar indicam seu grau de embriaguez. Ao telefone público, ele tenta chamar alguém, as vozes femininas reproduzem o som de chamada ocupada, ao mesmo tempo que indicam a repetição do ato em várias tentativas. Presume-se que o personagem tente alcançar a mulher da outra cena, que entra em um fliperama e entrega seu dinheiro para outro personagem masculino. Presume-se também que o bêbado que ela avista no final da canção seja o personagem "você" que estava no bar. Uma outra presunção, um pouco mais arriscada, é de que a personagem feminina seja a prostituta das canções anteriores, que agora vai ao encontro do seu cafetão e entrega-lhe o dinheiro. Outra arriscada suposição é que o personagem embriagado seja o motoboy que protagoniza as duas últimas canções do álbum. Não há nenhum elemento textual que confirme essas suposições, embora elas construam uma espécie de continuidade entre as cenas das canções. 
Trata-se uma cena que se constrói com mais ênfase na referência a elementos visuais, ao passo que os elementos sonoros são feitos de modo a caracterizar os sons e sensações desses ambientes. Em primeiro lugar, observemos que a música se organiza por blocos de frases musicais, alguns muito contrastantes entre si. O primeiro deles, tocado por guitarra e piano, executa uma frase atonal cuja recorrência das mesmas figuras rítmicas sustenta a entoação das vozes. O primeiro verso repete-se três vezes, e depois mais duas com a inversão da distribuição entre vozes masculina e feminina. Ao longo das repetições outros instrumentos vão se agregando, e assim como na canção anterior, a voz de Arrigo Barnabé vai adquirindo aos poucos a emissão tenso-estrangulada. As vozes femininas, embora agudas, não deixam de conotar certa sensualidade, principalmente nos glissandos ao entoar "sujo". O registro agudo dessas vozes encontra eco nos instrumentos de sopro, que também operam num registro agudo e com um timbre metalizado. Eles reproduzem linhas melódicas do canto, mas nem sempre em sincronia com ele: repetem melodias que já foram cantadas ou adiantam outras que ainda não foram. Tem-se assim, em momentos da canção, várias linhas melódicas sobrepostas, emissões hiperagudas, timbres metálicos, excesso de informações, repetição ao mesmo tempo incessante e dessincronizada de versos e melodias, somadas à persona "tenso-estrangulada" do narrador masculino. Sobretudo na estrofe que descreve a cena do bar de fórmica vermelha, ouve-se ao fundo a repetição melódica, rítmica e verbal do verso "era um balcão de bar..." ao mesmo tempo em que vários outros fragmentos musicais/entoativos se somam ao relato. Essa sobreposição de elementos contrastantes desperta uma sensação de saturação, de caos sonoro, adequada à descrição do bar e do antro sujo de diversões eletrônicas. O luminoso anuncia as palavras "Diversões Eletrônicas", ou seja, uma casa de jogos eletrônicos e fliperamas, muito comuns em São Paulo até a década de 1990, mas que perderam espaço para os jogos desenvolvidos para computadores pessoais. Em tais espaços de "diversões eletrônicas" era característico o ambiente saturado de luzes e sons artificiais, ambiente que é recuperado na atmosfera sonora da canção, onde as vozes femininas agudas e metalizadas, assim como as séries dodecafônicas provocam estranheza e desconforto nos ouvintes.

O narrador e sua emissão tenso-estrangulada, embora não incorpore nenhum personagem, coloca-se, conforme dito, como testemunha ocular. Arrigo Barnabé, em entrevista, diz ter-se inspirado em Gil Gomes na criação de sua persona e no seu estilo de emissão de voz, evocando assim o narrador radiofônico (e posteriormente televisivo) de programas policiais, onde crimes, assassinatos e violências de todo gênero são relatadas com sensacionalismo e dramaticidade. Mas não é sem interesse que ele se dirija diretamente à 
personagem como "você", provocando a síncrise típica da canção entre a comunicação representada e a comunicação direta com o ouvinte.

Os personagens - o bêbado, a mulher, o boyzinho e o garçom - também são criados na mesma tendência de trabalhar mais a chave da iconização do que a da narração. Ou seja, deparamo-nos muito mais com imagens, sensações, retratos do que com uma narrativa linear típica, configurando aquilo que Tatit chama de iconização: unidades de sentido indecomponíveis que reclamam uma captação em bloco (1996, p.266). O bêbado é a personagem e o interlocutário a quem se dirige o relato da canção, ao passo que a mulher é o sujeito principal de quase todas as ações, é ela quem "entra" no antro sujo, quem entrega o dinheiro, que vê o bêbado no chão, que sorri perversa. A sintética narrativa da canção centra-se na alusão da tensão entre essas duas personagens. "Você" embriaga-se e tenta sem sucesso entrar em contato com ela, ao passo que ela, o objeto de valor desejado, entrega o seu valor "grana" para um outro personagem masculino, caracterizado na canção como de alguma forma indigno dos prêmios que recebe (pois a alusão ao comportamento violento com suas amantes deixa a entender que não é só a grana que ela entrega) ao ser designado como boyzinho sacana e violento. Na terminologia semiótica de Luis Tatit, temos um sujeito que deseja estar em conjunção com seu objeto de valor, mas encontra-se separado dele. Estamos assim no terreno da disforia, da disjunção entre sujeito e objeto de valor que leva ao esvaziamento modal do personagem. A embriaguez causa para o "você" a perda da capacidade de andar e por fim, a perda total das capacidades representada na imagem de um bêbado caído ao chão. O programa narrativo aproxima-se de uma conjunção quando ela subitamente o avista no chão e sorri, mas trata-se de um sorriso perverso. Aqui aparece novamente a temática da ambiguidade e da ambivalência entre euforia e disforia, conjunção e disjunção ao longo do álbum Clara Crocodilo. A palavra "perversa" já supõe essa ambiguidade entre aparência e essência, entre o prazer e a dor. $\mathrm{Na}$ canção, o sorriso é perverso justamente por indicar o prazer em ver a infelicidade do outro. Mas o próprio narrador não é isento de perversidade, de prazer na observação e relato da cena, como está implícito, sobretudo no modo de entoar alguns versos como "só você não viu" e nas incursões de fala cotidiana pura (que também exercem a função de corte entre a cena no bar e a cena no fliperama, e desta ao encontro com o bêbado no chão). "Você me dá dó, pena" são palavras ditas não sem escárnio. A perversidade do narrador condiz com a atmosfera de programa policial sensacionalista evocada pela persona de Arrigo Barnabé, programas nos quais a denúncia dos crimes e o prazer sádico em descrevê-los se misturam, nos quais o 
prazer mórbido em descrever as atrocidades se revestem hipocritamente de denúncia e apelo à ordem.

A ambivalência entre euforia/disforia, atrativo e repulsivo faz-se presente também no desenho entoativo. Escute-se no primeiro verso a repetição da mesma figura rítmica tanto na parte instrumental quanto no canto. A entoação, próxima das formas típicas da tematização, é usada para a apresentação e caracterização do antro sujo; sobretudo o efeito sensual de glissando na entoação de "sujo" é indicativo dessa ambiguidade. A canção inteira segue nesse mesmo padrão de união entre melodia e letra: figuras rítmicas recorrentes, típicas da tematização, com a letra que trabalha a iconização de ambientes disfóricos. Exceção são os momentos de fala pura e da última estrofe que narra o encontro entre "ela" e "você". Nesta, estamos claramente no âmbito da passionalização, usado também ironicamente para mostrar a alegria perversa do encontro.

Mas, antes de prosseguir, é preciso fazer uma breve observação da intertextualidade que essa canção nos apresenta, quando o narrador cita os versos de outra canção. Essa citação é interessante sobretudo quando se tem em mente o deslocamento que há, nas canções de Arigo Barnabé, em relação às figuras tradicionais da canção brasileira: deslocamento de figuras "solares" como a baiana, a morena, o malandro, para figuras ligadas a uma urbanidade mais sombria, a metrópole dos luminosos, do fliperama, da prostituta, do marginal, das diversões eletrônicas. Desloca ao mesmo tempo que recupera o ébrio, boêmio urbano e noturno, como o personagem da canção Arranha Céu:

Arranha Céu:

Cansei de esperar por ela

Toda noite na janela

Vendo a cidade a luzir

Nestes delírios nervosos

Dos anúncios luminosos

Que são a vida a mentir

E cada vez que subia

O elevador não trazia

Esta mulher, maldição

E quando lento

Gemia o elevador que descia 


\author{
Subia o meu coração \\ Cansei de olhar as reclames \\ E disse ao peito não ames \\ Que o teu amor não te quer \\ Descansa, feche a vidraça \\ Esquece aquela desgraça \\ Esquece aquela mulher \\ Deitei-me então sobre o peito \\ Vieste em sonho ao meu leito \\ E eu acordei que aflição \\ Pensando que te abraçava \\ Alucinado apertava \\ Eu mesmo meu coração
}

A canção acima, de Orestes Barbosa, interpretada por Silvio Caldas, traz uma série de imagens e metáforas sobre a vida e a situação subjetiva de um habitante da grande cidade (como sugere o próprio título da canção Arranha Céu), que foram em parte recuperadas por Arrigo Barnabé em Diversões Eletrônicas. É surpreendente que uma canção brasileira de 1937, momento em que apenas se iniciava o processo de industrialização e a consequente explosão demográfica nas grandes cidades brasileiras, retrate com tanta intensidade imagens da vida urbana e escolha o arranha céu como imagem símbolo da canção. O núcleo de tensão reside na disjunção amorosa do eu lírico, que anseia pela presença da mulher amada, que anseia, portanto, pela conjunção do seu "eu" com o objeto de desejo. O eu lírico projeta então o seu estado interno de disjunção, a falta ocasionada pela ausência física da amada e sua presença virtual que se manifesta no estado de espera e carência amorosa, em metáforas que se constroem a partir da cidade observada pelo sujeito. O sujeito vê uma cidade que luz, mas cujo luzir advém de "delírios nervosos / Dos anúncios luminosos / Que são a vida a mentir". O ouvinte pode facilmente imaginar, a partir desses versos, o mundo das imagens publicitárias, no qual é comum que se representem casais em estado de perfeita conjunção amorosa, assim como o impacto que essas imagens presumivelmente causam no sujeito da canção, que vê o brilho desses anúncios, mas percebe-os como delírio e mentira. O próximo elemento que a canção traz como metáfora da disjunção amorosa é o elevador que, a cada vez que sobe, lembra o eu lírico da ausência da amada, experimentada como maldição. A 
cada vez que o elevador desce, dispara o coração do sujeito. Na próxima estrofe voltam os anúncios ("as reclames") e a presença da disjunção amorosa. O paralelismo entre o brilho mentiroso dos anúncios e a ilusão amorosa é ainda mais estreito na estrofe seguinte, onde a ação de fechar a vidraça equivale a esquecer "aquela desgraça", "aquela mulher". Contudo, a mesma relação entre imagens enganadoras (no sentido de trazer uma presença apenas virtual do objeto de desejo) e a presença "fantasmagórica" da amada transfere-se nos versos finais para o sonho, em que o sujeito "alucinado" aperta o próprio coração pensando abraçar a amada.

“Arranha céu" e "Diversões eletrônicas" aproximam-se ao tematizarem o desejo frustrado seguido pela presença virtual dolorosa do objeto de desejo, e o paralelo desse estado psíquico com as imagens luminosas, os letreiros e reclames. Imagens atraentes, mas que, de alguma forma, não cumprem a "promessa de felicidade" que lhes é implícita. Em ambas as canções, as desilusões com a promessa de felicidade amorosa funcionam ao mesmo tempo como uma crítica implícita ao universo urbano da propaganda e do consumo.

Apesar da proximidade, a diferença entre a persona que enuncia a canção de Orestes Barbosa e a de Arrigo Barnabé não poderia ser maior. A de Arrigo, incorporada em sua emissão gutural, já carrega por si só traços de agressividade. Podemos falar de uma aparência agressiva no sentido de Goffman, a qual está em consonância com a maneira: os estímulos indicadores do tipo de interação proposta. A agressividade e perversidade do narrador com relação ao seu personagem estende-se, pela síncrise, ao ouvinte, "você". Desse modo, a canção não apenas retrata como também instiga o ouvinte a adentrar em seus meandros e antros. Ao interpelar o ouvinte de forma sarcástica, ao descrevê-lo como digno de pena, verme, farrapo humano, objeto do riso perverso da mulher que deseja, Arrigo procede a uma profanação do ouvinte, profanação semelhante à qual estão sujeitos os frequentadores dos antros sujos - bêbados prostitutas e farrapos. Essa animosidade em relação ao ouvinte apenas aumentará nas últimas canções do álbum.

\title{
4. Instante
}

\author{
Desapareceu \\ Foi sumindo \\ Como um som se vai \\ Sempre achei \\ Não é só som \\ É vento nas folhas \\ Murmúrio de água
}


A canção Instante é considerada pelo próprio Arrigo como algo destoante do álbum Clara Crocodilo, uma canção que pouco se encaixa no conjunto e que poderia ter sido deixada para um outro álbum-. Contudo, essa canção não deixa de ter traços interessantes para se pensar a estética do conjunto; ela funciona na economia do álbum como uma espécie de interpolação entre blocos de canções, assim como um entreato que prepara um corte na narrativa.

Diferentemente das três canções anteriores, temos aqui um andamento lento, as curvas melódicas se expandem em longos passeios pelos campos da tessitura intercalados por saltos. Deparamo-nos com uma atmosfera dramática e introspectiva, ao contrário do que vinha sendo feito até então, onde velocidade do andamento, uso desmedido da dissonância e tematização compunham um ambiente sonoro saturado. A instrumentação, feita exclusivamente com instrumentos de sopro, contribui para o clima etéreo da peça. De todo o álbum essa é a faixa que menos se aproxima das convenções da canção popular, assemelhando-se muito mais a uma peça erudita, um poema musicado. Arrigo aponta para a influência de Debussy nessa canção.

A entoação da voz, exclusivamente feminina (e apenas uma voz) integra-se ao clima dramático e etéreo da parte instrumental, declamando versos que também destoam da tendência que vinha sendo construída até então. Em vez de imagens fortes de ambientes urbanos, esses versos aludem à transitoriedade, presente no som que se vai e no murmúrio de sons naturais. De fato, uma contemplação algo melancólica, o spleen que advém da percepção da passagem, anunciada já no próprio título, Instante. Contudo, também essa melancolia e essa tematização da natureza fazem parte de um "sentimento" da modernidade que vinha se desenhando nas canções anteriores. Um sentimento que, conforme veremos adiante, ressoa em Baudelaire, na melancolia da grande cidade, na percepção do moderno como o transitório, mas também como o decadente. Desse modo, essa canção traz novos elementos para caracterizar o narrador do álbum Clara Crocodilo, para caracterizar o olhar que ele lança à cidade e às figuras que circulam por alguns de seus espaços sombrios. Por trás do narrador perverso e explosivo de uma canção como Diversões eletrônicas há também um observador introspectivo e melancólico, a refletir sobre a transitoriedade.

\section{Sabor de Veneno}

Você já viu aquela menina

Que tem um balanço diferente 


\author{
Se você viu e reparou \\ Ela tem um jeito de sorrir, de falar, de olhar \\ Que me deixa louco \\ Ah, eu fico louco \\ Não sei se ela veio da lua \\ Ou se veio de marte me capturar \\ Só sei que quando ela me beija \\ Eu sinto um gosto \\ Uma coisa estranha, um negócio esquisito \\ Meio amargo do futuro \\ Sabor de veneno
}

Depois do momento de interpolação feito pela última canção, Sabor de Veneno dá continuidade ao álbum com uma cena que também não se conecta diretamente com aquela que foi desenvolvida nas três primeiras. Diga-se logo, apenas as duas últimas canções de alguma forma retomam a temática que ali foi desenvolvida, mas também apenas indiretamente. Semelhante à canção anterior, esta começa apenas com instrumentos de sopro, mas, em contraste, eles perfazem aqui um ataque rítmico intenso. Ou seja, a curva melódica nesse caso não se alonga pelo campo da tessitura, mas cria temas que se repetem insistentemente, reafirmando um pulso rítmico bem delineado. A curva melódica está, portanto, no terreno da tematização, e a letra da canção vem reafirmar esse sentimento de conjunção com o objeto de desejo: aqui, como em tantas outras canções, trata-se de uma menina, seu jeito, seu balanço ao caminhar. Ainda assim, o movimento da melodia é construído sobretudo no registro hiperagudo dos instrumentos, e a melodia acelerada e repetitiva é trabalhada aqui novamente na base da dissonância. Ou seja, ao contrário do que ocorre normalmente, quando a melodia que constrói temas é feita de consonâncias, o que é homologamente reafirmado na letra com sentimentos eufóricos de conjunção entre sujeito e objeto, Arrigo tem a proeza de construir temas e celebrar a conjunção na base da dissonância. O estranhamento e a ambiguidade que isso causa no ouvinte não são pequenos: se, por um lado, reconhecemos os temas, as conjunções, os sentimentos eufóricos, reconhecemos ao mesmo tempo a dissonância, a disjunção e disforia.

Duas rápidas observações: vemos aqui claramente como, apesar de tantos elementos incomuns, "vanguardistas", o trabalho de Arrigo Barnabé encontra-se plenamente no terreno da canção popular (embora a canção anterior seja a única do álbum que fuja disso), que as formas de junção entre letra e melodia obedecem as tendências observadas por Luiz Tatit, e 
que se valem de muitos dos recursos típicos de persuasão do ouvinte, embora consigam introduzir distorções e ambiguidades até então impensáveis no seio dessa linguagem. A segunda diz respeito à afirmação de Wisnik de que Arrigo seria um nosso outro Tom Jobim, um Tom atonal. Sem entrar no mérito de detalhar a coerência ou não dessa afirmação num sentido global, a canção Sabor de Veneno possui elementos que nos remetem diretamente ao clássico Garota de Ipanema. A construção da cena possui a mesma estruturação: ambas as cenas começam com uma interpelação do interlocutor, valendo-se de um deítico visual: "Olha, que coisa mais linda", "Você já viu...". A partir desse simulacro de situação de comunicação que "puxa" o ouvinte para dentro da cena, como se fizesse parte dela, o interlocutor delineia o seu objeto de desejo: "Mais cheia de graça /É ela, menina / Que vem e que passa", "[...] aquela menina / Que tem um balanço diferente /Se você viu e reparou / Ela tem um jeito de sorrir, de falar, de olhar". Mas, se em Garota de Ipanema temos uma segunda parte na qual prevalece a passionalização, em que o interlocutor pondera seu afastamento do objeto, a canção de Arrigo permanece tempo todo na marcação rítmica acelerada da tematização e logra injetar, mesmo aí, o abjeto no seio do objeto de desejo: o sabor de veneno.

Ainda a respeito da construção da cena em Sabor de Veneno, estamos aqui novamente na chave da iconização: menos do que a apresentação de um programa narrativo em que uma transformação de um estado a outro se desenvolve, a canção constrói um ícone a ser apreendido em bloco, letra, melodia e ritmo trabalham conjuntamente para a construção da menina e seu jeito, seu balanço (aludido na marcação rítmica, a qual chega mesmo a lembrar a síncope do samba). O recurso da ilusão enunciativa é acionado aqui pelo simulacro de comunicação, pelo deítico que simula um diálogo direto e convoca a observação para o euaqui-agora da enunciação. É digno de nota o recurso à visualidade, tão marcante em todas as canções do álbum: o interlocutário se posiciona como o observador da cena, e a reconstrói para o ouvinte a partir de sua observação. Isso interessa não apenas pelo recurso estético que isso configura (não por acaso o álbum foi reinterpretado em ópera e ballet), mas também porque ajuda a delinear a posição da persona incorporada pela voz de Arrigo Barnabé. É possível perceber que essa persona vai se delineando progressivamente como um observador/avaliador das cenas retratadas (no jargão semiótico de Tatit isso seria chamado de destinador julgador), semelhante ao gigantesco olho de crocodilo estampado na capa do álbum.

Contudo, esse observador não está fora da cena, introduzindo-se nela nos reflexivos: "Que me deixa louco", "Quando ela me beija". É a partir desse envolvimento mais íntimo 
do interlocutor com a cena que são introduzidos os marcadores fóricos decisivos: ela o deixa "louco", e a partir do beijo ele sente uma coisa "estranha", um gosto amargo do "futuro". Já ao colocar a dúvida a respeito da origem da menina, (lua ou marte?), o estranhamento em relação ao objeto de desejo se faz presente, mas com a tematização do "gosto amargo do futuro" e "sabor de veneno", a questão da ambiguidade e ambivalência, que permeia todo o álbum, faz-se aqui definitivamente presente. Além disso, ao associar a menina com extraterrestre e o beijo com o futuro, a canção que até então parecia tratar apenas do desejo pessoal vai além dessa dimensão, alçando-se para uma tematização do futuro, da modernidade. A ambiguidade dela é traduzida aqui na metáfora do beijo, amargo, mas apreciado; venenoso, mas ainda assim um beijo. Mais um passo e estamos no terreno da perversão, do sadismo, do prazer no abjeto: tema da próxima canção.

Desse modo, é interessante notar como essa canção remete à história da música popular brasileira, como ela ao mesmo tempo acata e embaralha as categorias da linguagem canção, e como ela logra num contexto insuspeito, o da celebração do objeto de desejo (tema típico da canção temática) reintroduzir o topos da ambivalência e do moderno. Todos esses aspectos do conteúdo são reforçados na forma da melodia: um samba acelerado e sincopado construído de linhas atonais.

\section{Infortúnio}

Ontem, no cemitério

Ela gritou, gritou muito

Quando fecharam o caixão de seu marido

Ficou histé, histé, histé, histérica

Blasfemou, 'rancou cabelos

Rogou a Deus que a levasse também

Implorou, rasgou as roupas

Se arrastou gritando entre as estátuas

Que desespero! Ela tava desesperada

Seu corpo inteiro tava doendo de saudade

Do seu marido... do maridinho adorado

Anoiteceu e ela ficou ali jogada

Saudade, do maridinho adorado

Ela estava com saudade

A soluçar e quando veio a madrugada 


\author{
Ela saiu e foi até o Riviera \\ E se entregou a todo homem que encontrou \\ Hoje, ela só bebe. Nunca esqueceu a sua morte \\ Vive nos bares e cafés dizendo a todos: \\ Ele morreu porque pensou, pensou demais \\ E ela grita, e ela blasfema \\ E roga a Deus que leve todos também
}

Essa canção também foi apresentada no Festival Universitário de MPB da TV Cultura de 1979. Arrigo relata que a canção chamou a atenção da censura militar, que não queria permitir a sua apresentação no festival.. A estratégia usada pelos organizadores foi a de "trocar" duas canções panfletárias (que não haviam sido classificadas para o festival) pela permissão da apresentação de Infortúnio. . Apesar de não haver nenhuma referência explícita, Arrigo reconhece que parte da letra foi inspirada no assassinato de Vladmir Herzog por parte dos militares, de onde o verso "Ele morreu porque pensou, pensou demais".

A canção tem início com uma linha melódica executada por cordas, acompanhada por grunhidos de choro ao fundo. Entra então a voz feminina em "bel canto", no estilo operístico, configurando mais um momento do álbum que se afasta da entoação típica da canção. Essa forma de união entre melodia e letra predomina por toda a primeira estrofe. Logo após, entra o piano em fortíssimo, e é possível perceber como as mãos de fato esmurram as teclas, ao estilo de Barthók. Segue-se então a entrada dos instrumentos de sopro, e a melodia assume um perfil mais acelerado, temático, e aos poucos reingressa no tipo de perfil melódico/cancional característico do álbum. Segue-se um longo interlúdio instrumental, ao qual vem se juntar baixo, bateria, guitarra elétrica e sintetizador, reintroduzindo a instrumentação característica do rock e da canção popular. Após o interlúdio, o canto reaparece na tendência insólita de se juntar a tematização melódica acelerada ao uso quase ininterrupto da dissonância. A parte instrumental obedece à estrutura recorrente nas canções do álbum, em que diferentes módulos de melodias que acompanham os versos são embaralhados, desestruturando a progressão linear da canção.

Já a partir da entrada do canto após o interlúdio, a narração da cena é retomada. Se na primeira parte o andamento lento e a entoação operística davam um ar grave, dramático, triste à tragédia relatada, com a transformação da entoação pelo andamento acelerado e também pelo uso agudo das vozes o relato assume um ar mais cínico. Sobretudo o uso do diminutivo em "maridinho" e o glissando sensual na entoação de "adorado" dão um tom perverso ao relato, entrevê-se certo sadismo na observação do sofrimento da viúva. Segue 
então o relato do sofrimento de uma mulher ao presenciar o enterro do marido. Sofrimento exposto sem pudor, sofrimento apreendido como um espetáculo, como escândalo. O luto transfigura-se então na entrega ao álcool e ao sexo, e finalmente em ódio, desejo de que todos morram. A cena é apresentada como relato de uma observação, tem início com o deítico temporal "ontem" e espacial "no cemitério", e assim surge uma construção que faz uso mais uma vez do enunciador observador como estratégia de persuasão da "verdade enunciativa". O enunciador não chega a configurar-se como personagem da cena. A menção ao "Riviera" localiza a cena muito provavelmente no cemitério da Consolação, em São Paulo, em cuja proximidade se encontra o conhecido bar.

A debreagem enunciva distancia o narrador da cena, e nos defrontamos com um relato de um observador anônimo, mas ainda assim, a linha entoativa nos dá indícios do envolvimento afetivo, "fórico" com o relato. Da lentidão à aceleração tem-se um movimento que vai da alusão a uma tristeza compadecida (muito embora o tom grandiloquente da ópera também possa ser encarado como uma forma de ironia) à excitação sádica. Não apenas nas vozes femininas como também na emissão "tenso estrangulada" de Arrigo, o narrador de programas policiais, sente-se certa cumplicidade com o ódio da personagem. O movimento emocional da personagem da canção vai numa direção parecida, da dor ao ódio, do sentimento de perda ao desejo de destruição. Pode-se sem dúvida notar que, dado o contexto de ditadura e o subtexto secreto de denúncia de um assassinato político, esse ódio, bem como a identificação com ele, não são uma forma de sadismo gratuito, mas expressão de revolta política.

Observe-se também o deslocamento social realizado pela viúva: de uma posição "aceitável" ou até mesmo socialmente tida como "respeitável" de mulher casada, ela passa a uma mulher identificada com o álcool e a promiscuidade. Esse movimento de decadência na escala social de status possui ressonância semântica na transição do dia à noite: "anoiteceu", "e quando chegou a madrugada". Isso é bastante significativo do tipo de revolta social e política manifesta no álbum de Arrigo. Pois o ódio, que não pode confessar a quem se dirige, move-se então para a sombra, para a noite, para as margens. A canção apresenta uma narrativa que, à primeira vista, poderia ser só mais uma das que são apresentadas em programas policiais, nas páginas de jornais sensacionalistas. Contudo, o contexto extramusical faz entender que essa tragédia aparentemente microssocial, particular, enquadra também questões mais amplas Essa canção integra-se ao álbum ao retratar o processo de declínio que leva da destituição ao ódio, o qual é justamente o tema das duas 
próximas canções, que retratam a personagem título "Clara Crocodilo". Nelas, o caráter social do desejo de destruição faz-se mais evidente.

\title{
7. Office-boy
}

\author{
Nome: Durango \\ Profissão: Office-boy \\ Trabalhava que nem um \\ Desgraçado a semana inteira \\ No sábado, porém, ele estava duro
}

Era sábado e ele ali, sozinho

Sem nem um tostão

Pensava naquela vedete morena

Que tirava a roupa no Áurea Strip Show

Pensava nela dançando coquete

Discoteque

Ele estava duro e resolveu ligar a TV, a TV

A TV, a TV

Ele viu uma chacrete linda

Mascando chiclete, olhando pra ele

Sorrindo, sorrindo

Primeiro erro: ligar a TV

Segundo erro: prestar atenção na imagem

Que estava sendo transmitida

Era a face de alguém conhecida!

Sim, há muito tempo

Não podia ser! Aquele rosto, ele o conhecia

Oh não! Deus, era Perpétua

Sua antiga namoradinha

Mas ela era apenas... ela era apenas...

Ela era caixa num supermercado

Todo dia ela só, só apertava os botões

E aquelas máquinas cantavam

Sim, de uma simples caixa a uma estrela famosa

Se você quiser possuí-la novamente

Você precisa arranjar muito dinheiro, Durango 
Como era mesmo aquele anúncio no jornal?

Durango, aquele anúncio no jornal

Procura-se rapaz para testar um novo produto

Paga-se bem

Ele então saiu pra procurar

Sozinho o tal endereço

E deu numa casa escura, sombria

Que até dava medo mas ele entrou

Uma enfermeira bonita, gostosa

Falou assim pra ele:

Venha aqui, querido

que eu vou te dar

uma injeção especial, você vai

flutuar

E ele flutuou. Sim, flutuou pra longe

dali, envolvido numa sensação deliciosa

Mas, o que ele não sabia, era que estava

sendo transformado num terrível monstro

mutante, meio homem, meio réptil, vítima

de um poderoso laboratório multinacional

que não hesitou em arruinar sua vida para

conseguir seus maléficos intentos.

Os cientistas haviam calculado tudo, mas o

que eles não imaginavam era que aquela criatura

havia conservado parte de sua

consciência. E logo, sim meus amigos, e logo

todo seu poder se

transformou em fúria e violência sobre-humana.

Os cientistas foram os primeiros

a conhecer sua fúria. Depois, toda a cidade

estremeceria ao ouvir falar em

Clara Crocodilo.

Nas duas últimas canções do álbum, os traços estilísticos que Arrigo Barnabé vinha desenvolvendo até aqui encontram seu paroxismo, sua máxima intensidade. Por exemplo, o uso de construções modulares que se alternam e por vezes se embaralham, o uso do caos sonoro como recurso para a construção estética da cena, a construção de um narrador observador (que se escancara enquanto narrador de uma história ficcional) que se aproxima, 
pelos traços caricaturais e "campy" 83 do estilo das histórias em quadrinhos, e também o uso da conjunto de aceleração, tematização e dissonância. Se, nas canções apresentadas até agora, apesar do modo incomum da construção, elas guardavam certo cuidado com a verossimilhança das cenas, no sentido de que o relato poderia muito bem passar por uma cena real, nessas duas últimas canções a ficcionalidade ganha muito mais espaço, adquirindo liberdade para representações mais imaginárias.

Esta canção já inicia na conjunção entre dissonância, tematização e aceleração. A mesma figura rítmica sustenta as frases atonais sendo repetidas com variações pelos instrumentos de sopro. Essa "cama" rítmico-melódica ao mesmo tempo repetitiva (por conta da figura rítmica reincidente) e desestabilizadora (por conta das variações das linhas melódicas atonais) sustenta a entoação que, em praticamente toda a canção, permanece na tendência à oralização. A construção da cena principia pela caracterização do personagem de um modo que não poderia ser mais explícito: nome e profissão são anunciados como se estivesse lendo uma ficha policial. A voz de Arrigo Barnabé assume, apenas pela segunda vez em todo álbum, a narração, introduzida numa debreagem enunciva, afastando a história do narrador, e dessa vez sem grandes preocupações em esconder ou disfarçar a ficcionalidade do relato. Aparece então o protagonista, o motoboy "Durango", cujo nome já indica sua questão principal: a falta de dinheiro, o paradoxo de trabalhar exaustivamente e ainda assim não ter dinheiro para, sábado à noite, realizar suas aspirações, sobretudo eróticas. Note-se a ambivalência do adjetivo "duro" em "estava duro e resolveu ligar a TV", ou seja, sem dinheiro e ao mesmo tempo sexualmente sedento. A saída foi tentar aliviar-se pelas imagens televisivas. A configuração dessa cena traz de volta a temática trabalhada nas três primeiras canções: o binômio sexo/dinheiro, bem como a tensão entre imagem e realidade. Lembre-se da intertextualidade de "Diversões Eletrônicas» com os "Delírios nervosos dos anúncios luminosos que são a vida a mentir". O símbolo que concentra a ambivalência da imagem, atraente mas ilusória, nesta canção é a TV. Repare-se no crescendo das vozes femininas ao repetir quatro vezes essa palavra. Traduzindo isso para a linguagem dos quadrinhos, ter-se-ia possivelmente uma sequência de closes em que a TV ocupa um espaço cada vez maior do quadro.

Transforma-se então o módulo instrumental, tem-se um sintetizador que repete em looping uma escala cromática descendente, ao passo que uma figura ritmo-melódica se repete também insistentemente ao fundo. Esse é um dos momentos de maior aceleração da

${ }^{83}$ Camp é um termo inglês, que em estética designa um estilo vulgar, exagerado, kitsch, mas que desperta o interesse justamente pelo valor irônico ou mesmo contestador que essas qualidades podem adquirir. 
entoação em todo o álbum. Enquanto as vozes femininas repetem diversas vezes os versos "Ele viu uma chacrete linda / Mascando chiclete, olhando pra ele / Sorrindo, sorrindo", a voz de Arrigo dá sequência à narrativa. Se a estrofe anterior deu ênfase ao binômio sexodinheiro, esta tematiza a ambivalência da imagem em maior detalhe: os dois grandes erros do protagonista foram ligar a TV e prestar atenção na imagem, a partir dos que se desencadeia um processo de sedução que terá consequências drásticas para ele. Note-se de passagem que o que se apresenta como imagens ambivalentes, enganadoras e mesmo perigosas não é a imagem em si, mas um estatuto muito particular de imagem: o luminoso, os anúncios, a TV. São as imagens publicitárias.

Ao reencontrar a antiga namorada transformada em chacrete, o protagonista decide ir em busca do dinheiro necessário para possuí-la. É digno de nota que, com a entrada da próxima estrofe, onde é tematizada a condição de Perpétua antes da fama, a canção se desacelera e retoma uma figura rítmica muito semelhante àquela que sustenta os versos "era um balcão de fórmica vermelha" em Diversões Eletrônicas. Intencionalmente ou não, esse detalhe reforça a proximidade dos temas tratados nessas duas canções. Se ali tínhamos um ambiente de diversões artificiais, eletrônicas, no caso de Perpétua há uma trabalhadora reduzida ao estado maquinal de apertar botões ao passo que as máquinas cantam. No aspecto mais geral da narrativa, há um personagem masculino que, também por conta da frustração sexual-amorosa, se embriaga e se torna objeto do riso perverso daquela que era seu objeto de desejo. Há aí um movimento de perda que culmina na figura da humilhação. Já nessa última canção, o mesmo mote da frustração sexual, potencializada pela falta de dinheiro, leva à perda das características humanas e à passagem da vítima a agressor, da perda à destruição (reencontram-se também ecos com o quadro da viúva).

Interessante notar o processo que leva "Durango" ao laboratório. É o próprio narrador, na voz de Arrigo, que sugere o dinheiro como meio para reconquistar a namorada, é ele também quem aponta o anúncio no jornal, interpela a personagem protagonista diretamente, como que o cutucando com o anúncio. Depois de uma breve retomada da escala descendente no sintetizador durante a entoação do anúncio, volta-se ao módulo instrumental que sustentava a primeira estrofe quando da narração da chegada de Durango ao laboratório. Todos os traços são aqui exagerados e caricaturais, reafirmando a estética dos quadrinhos: a casa escura, a enfermeira gostosa, a injeção. Na entoação de "injeção especial", as vozes femininas retomam o crescendo utilizado nas repetições de "a TV", apontando novamente para um momento de clímax e inflexão na narrativa. Logo após, há um ralentando, a diminuição do andamento da música feito por meio de fragmentos sonoros, os quais se 
retraem para o segundo plano, deixando a cena para uma voz feminina, delicada, que declama a última estrofe com uma pronúncia "meiga", contrastando com a história narrada de ficção científica e terror. A "fachada pessoal” dessa voz aproxima-se do tom narrativo de histórias infantis, reafirmando a distância irônica e até mesmo o estranhamento com relação ao conteúdo da narrativa. Não seria absurdo supor que esse distanciamento serve exatamente para dar o tom irônico necessário a um relato tão caricatural. Narra-se aqui a transformação de Durango em Clara Crocodilo. Essa forma monstruosa ainda guarda parte de sua consciência humana, o que alimenta seu ímpeto destrutivo contra os cientistas e a cidade.

Note-se que a queda do protagonista na cilada e sua transformação no "delinquente", "facínora", Clara Crocodilo não foi algo diretamente relacionado com as questões da violência urbana e exclusão social (na próxima canção a aproximação do protagonista com a questão social da delinquência e da violência urbana ficará mais evidente) mas sim a desilusão amorosa. A propósito, em um show no Sesc Pompéia, em 2015, em que Arrigo reinterpretava momentos de sua carreira (dos primeiros álbuns experimentais às posteriores releituras de clássicos da canção popular), foi encenado um curioso encontro musical de Clara Crocodilo com Paulinho da Viola. O monstro Clara Crocodilo vinha destruindo a cidade, no melhor estilo de filmes de terror de baixo orçamento, e, ao se deparar com um ébrio sentado no banco com um maço de flores na mão e lágrimas nos olhos (a imagem da capa do álbum "Nervos de aço" de Paulinho da Viola de 1973), o monstro compadeceu-se, identificou-se com o ébrio e dele escutou "Você sabe o que é ter um amor meu senhor...", a canção Nervos de aço, de Lupicínio Rodrigues. Essa anedota mostra que, mesmo com toda a inovação e experimentação, as canções de Clara Crocodilo guardam inúmeras proximidades e mesmo intertextualidades com a tradição da música popular brasileira que se desenvolveu a partir da introdução da indústria fonográfica no Brasil-. O trabalho com a isotopia da desilusão amorosa é mais uma dessas proximidades, assim como o fato, que temos salientado ao longo desta análise, de Arrigo trabalhar majoritariamente dentro da linguagem especificamente cancional, embora quase sempre testando os limites dela.

O tema da desilusão amorosa permeia o álbum. Já foi visto em Diversões Eletrônicas e agora em Office-boy. Mesmo em Infortúnio, é possível constatar a presença da dor amorosa. Contudo, mesmo que este seja o mote que desencadeia a perda, a humilhação, o ódio e depois a vontade de destruição, não nos impede de ver a dimensão social desse ódio. No caso da viúva da sexta faixa, o contexto extramusical esclarece a dimensão política desse ódio. Já nas demais faixas, a construção dos personagens e dos espaços é sugestiva. $\mathrm{O}$ “antro sujo" é indicativo do espaço frequentado pela ralé, e o ambiente noturno dá ensejo para a 
entrada de personagens sombrias, que ocupam a face oculta, ocultada e desvalorizada da sociedade: a prostituta na boca da noite, o coroa num carro esportivo, o cafetão, o bêbado jogado no chão. Já o office-boy pertence a uma profissão que é em si mesma estigmatizada. A falta de dinheiro crônica de sua posição coloca-o a um passo da marginalidade, e bastou a provocação, a sedutora mentira de uma imagem para que ele se deslocasse à casa escura e sofresse a transformação que, afinal de contas, estava no plano daqueles que ocupam uma posição muito mais poderosa que a sua. Assim se explicita no álbum o conflito entre dois sistemas de valores que, apesar dos pesares, se interpenetram, e que encontra forte ressonância semântica na oposição claro/escuro. Como dito anteriormente, o próprio título Clara Crocodilo foi pensado como um jogo de palavras entre os opostos luz, claridade, “clara", e "crocodilo", associado ao pântano, à profundeza, à sombra. À noite foi ambientada a primeira cena, da prostituta, assim como aquelas do drive-in e do antro sujo. Viu-se também que a decadência da viúva é acompanhada pela transição do dia à madrugada, e o office-boy encontra sua desgraça numa casa escura. A noite traduz-se em personagens relegados à sombra que, culminando no marginal/monstro, virão assombrar os habitantes da "luz", do lado legitimado e aceito da sociedade, na forma espectral da canção. Não apenas como sublimação estética da violência urbana e de ambientes degradados, as canções de Arrigo Barnabé também almejam, e isso ficará evidente na próxima canção, uma agressão simbólica do ouvinte, enquanto membro hipócrita de um setor legítimo da sociedade que produz o lado sombrio, mas não é capaz de olhar para ele.

\section{Clara Crocodilo}

São Paulo, 31 de dezembro de 1999. falta

Pouco, pouco, muito pouco mesmo para o

Ano 2000 e você, ouvinte incauto, que no

Aconchego de seu lar, rodeado de seus

Familiares, desafortunadamente colocou

Este disco na vitrola, você que, agora,

Aguarda ansiosamente o espocar da

Champanha e o retinir das taças, você,

Inimigo mortal da angústia e do

Desespero, esteja preparado... o pesadelo

Começou. sim, eu sei, você vai dizer que é

Sua imaginação, que você andou lendo

Muito gibi ultimamente, mas então por

Que suas mãos tremeram, tremeram, 
Tremeram tanto, quando você acendeu Aquele cigarro... e por que você ficou tão Pálido de repente? será tudo isto fruto da Sua imaginação? não, meu amigo, vá ao

Banheiro agora, antes que seja tarde

Demais, porque neste mero disco que você Comprou num sebo, esteve aprisionado

Por mais de 20 anos, o perigoso marginal, $\mathrm{O}$ delinquente, o facínora, o inimigo

Público número 1, Clara Crocodilo...

Quem cala consente, eu não calo

Não vou morrer nas mãos de um tira

Quem cala, consente, eu desacato

Não vou morrer nas mãos de um rato

Não vou ficar mais neste inferno

Nem vou parar num cemitério

Metralhadora não me atinge

Não vou ficar mais neste ringue

Ei, você que está me ouvindo, você acha

Que vai conseguir me agarrar? pois então,

Tome...

Já vi que você é perseverante. vamos ver Se você segura esta...

Meninas, vocês acham que eles querem

Mais?

Querem sim!

Você que então é tão espertinho, vamos

Ver se você consegue me seguir neste

Labirinto.

Clara crocodilo fugiu

Clara crocodilo escapuliu

Vê se tem vergonha na cara

E ajuda clara, seu canalha

Olha o holofote no olho,

Sorte, você não passa de um repolho

Onde andará clara crocodilo? onde

Andará? será que ela está roubando algum 


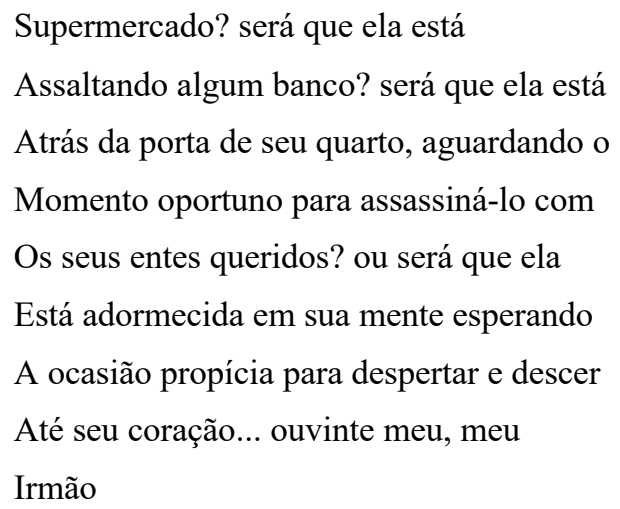

A última canção do álbum começa com um fragmento de música eletroacústica retirada de uma peça de Stockhausen. Apesar da erudição da referência, esse fragmento serve muito bem ao propósito de preâmbulo e ambientação para a cena da canção: uma cena de terror e ficção científica "campy", o retrato da libertação, fuga e revolta do personagem Clara Crocodilo. Esse fragmento é também sugestivo do uso de ruídos que essa canção fará na configuração do seu ambiente sonoro, sobretudo na primeira parte. Naquele que podemos designar como o primeiro de seis módulos da canção, temos a voz de Arrigo Barnabé com sua emissão "tenso estrangulada" ocupando o primeiro plano da cena sonora, neste que talvez seja o momento de maior e mais longo destaque da sua voz em todo o álbum. Ela claramente mimetiza uma emissão de programa policial radiofônico, e por isso mesmo se está no terreno da oralização, da intervenção da fala cotidiana pura. Junto com a voz, há a entrada do baixo e da bateria ao fundo, repetindo em looping uma frase musical descendente no registro grave, criando uma ambientação sonora pesada, escura e ameaçadora. É com esse cenário que o narrador incorporado na voz de Arrigo Barnabé inicia o relato da cena num modo típico da narração de histórias: a debreagem enunciva constrói o tempo e o espaço do relato num "ele-lá-outrora" distante do narrador: "São Paulo, 31 de dezembro de 1999".

Que as demais cenas do álbum estejam ambientadas em São Paulo era algo até agora apenas implicado em referências discretas, mas esse ponto é escancarado logo nas primeiras palavras da canção, o que está em consonância com outras "revelações" que serão feitas ao longo da canção. A ambientação temporal da cena é então a data da virada do século e do milênio (embora tecnicamente isto tenha ocorrido apenas no ano seguinte), data carregada de profecias, simbologias e expectativas, uma espécie de materialização da ideia de futuro presente nas décadas que a precederam. A cena prossegue com a descrição de um evento comum para essas datas comemorativas: a reunião familiar, o brinde à meia noite, a música na "vitrola": estamos portanto no espaço inverso ao dos ambientes escuros, sujos, degradados e marginais que vinham sendo retratados até aqui; no oposto da obscuridade, a 
cena começa com uma intervenção do domínio da claridade. A libertação do protagonista, o monstro Clara Crocodilo advém justamente do ato de se colocar o disco para tocar. É interessante o jogo metalinguístico feito pela canção: ela retrata uma cena no futuro onde ocorre, justamente, sua reprodução em um aparelho sonoro, colocando em cena um simulacro de comunicação direta com o ouvinte, reconstruindo uma cena provavelmente semelhante àquela em que um ouvinte porventura estaria, caso tenha reproduzido a canção minutos antes da virada dos anos 2000. Nesse simulacro da situação de escuta da canção trazido para dentro da própria, a voz do narrador dirige-se diretamente ao ouvinte, descrevendo seu medo e nervosismo, bem como o perigo iminente que ele corre ao escutar essa canção Nesse jogo de espelhos, o simulacro da recepção dentro da própria canção introduz a dúvida: seria o marginal ali fruto da imaginação ou não? Com que tipo de entidade estaríamos lidando? Quem ou o que é Clara Crocodilo?

A entrada do segundo módulo marca a ruptura com o ambiente sonoro que vinha se estabelecendo até então. Da região grave da tessitura e uso de poucos instrumentos, passase agora para o registro agudo, sobretudo nas frases dos instrumentos de sopro e sintetizador, que assumem a condução da linha melódica. Voltamos aqui à conhecida conjunção de aceleração, formação de temas rítmico-melódicos bem delineados e a linha melódica atonal. A entoação também se transforma da oralização para a curva temática típica (não fosse a dissonância): repetição de uma figura entoativa bem delineada. Desse momento em diante é possível apreender a capacidade de Arrigo Barnabé, bem captada por Wisnik, de encontrar melodias cancionais nas linhas melódicas as mais incomuns. De fato, essa canção irá construir refrãos bem delineados nos próximos módulos, com linhas entoativas facilmente reconhecíveis e reproduzíveis (fáceis de cantar junto e que até mesmo "colam" no ouvido), recoberta por rimas também facilmente memorizáveis, configurando assim o momento do álbum que mais se aproxima da canção pop.

Os versos desse segundo módulo são entoados por uma voz masculina ainda não ouvida no álbum, e podemos presumir que se trata do próprio "Clara Crocodilo", sobretudo por conta do uso da primeira pessoa: "eu não calo", "eu desacato". Nessa estrofe, o enunciador coloca-se em contraposição a um anti-sujeito construído logo nos primeiros versos: "quem cala consente, eu não calo". A ele é atribuída a ação de calar, de silenciar e de consentir, ao que o protagonista contrapõe o seu não calar. "Não vou morrer nas mãos de um tira" identifica claramente o anti-sujeito ao policial (a gíria tira designa policial, mas também poderia servir para os membros das forças armadas) e à ameaça de morte que ele representa para o protagonista. Os versos seguintes obedecem a mesma estrutura, no lugar 
de "calo" entra "desacato" (trazendo para o campo semântico da canção a linguagem jurídico-policialesca) e no lugar de "tira", "rato". Nos quatro versos seguintes, as qualidades ameaçadoras do anti-sujeito são agora transferidas para a dimensão espacial: "inferno", "cemitério" e "ringue" caracterizam o espaço, a cidade à qual o protagonista se contrapõe e da qual pretende escapar. É interessante notar que esses poucos versos ocupam bastante espaço na canção, com eles é feito um jogo de permutações entre as vozes (Clara Crocodilo, Arrigo e o coro feminino) combinado com alternâncias das figuras ritmo-melódicas e entoativas. A aceleração do andamento e o jogo com as linhas entoativas evoca um ambiente dinâmico, em movimento, como se estivéssemos diante do protagonista em deslocamento pela cidade. Ao adentrarmos no âmbito de "Clara Crocodilo", é curioso que a ambiguidade e ambivalência que permeavam todas as outras canções estejam, pelo menos até aqui, suspendidas. Há aqui um sujeito e um anti-sujeito bem definidos, bem como uma contraposição clara e simples entre eles: Clara Crocodilo contra as forças da ordem e contra a cidade, naquilo que ela tem de infernal, de morte e luta, de onde ele deseja escapar.

A entrada do terceiro módulo também se dá em ruptura com o anterior. Dessa vez, com um súbito breque. A voz de Arrigo Barnabé retoma o primeiro plano, assim como o simulacro de diálogo direto com o ouvinte. A ambientação sonora faz uso do eco, evocando a impressão de espaço amplo vazio. Se antes se estava diante de Clara Crocodilo correndo pela cidade, agora ouvinte e protagonista (incorporado por Arrigo) chegam em outro espaço. Diferentemente da estrofe anterior, onde os anti-sujeitos eram a polícia e a cidade, agora a canção volta a ameaçar o ouvinte e a construí-lo como seu opositor. Retorna aqui também a estética "kitsch" e o distanciamento irônico do narrador. A persona na voz de Arrigo é caricatural, assim como seu pseudo ataque ao ouvinte. Se no princípio da canção ela o ameaçava de morte, nesse momento os ataques são apenas musicais. O coro feminino assume aqui status de personagem da canção, as "meninas", cujas vozes agudas e metalizadas contribuem para o aspecto caricatural, kitsch e irônico da cena. Isso persiste também nos últimos versos dessa estrofe, nos quais o desafio lançado soa muito mais como um convite ao ouvinte para seguir o protagonista no labirinto musical. Veja-se que a própria música, em sua parte instrumental, vai progressivamente adquirindo status de um personagem: os ataques são musicais, o labirinto também é musical. Isso dá continuidade ao jogo metalinguístico iniciado na primeira estrofe: a canção tematiza seus próprios poderes, a princípio ameaçadores, e agora um jogo mais lúdico do que ameaçador. O que vai se tornando mais claro é a síncrise operada em "Clara Crocodilo", ele é um personagem, mas também serve de signo para a própria música. Quem esteve, afinal de contas, aprisionado 
por mais de 20 anos em um disco esquecido é a música, transfigurada em um de seus personagens. Isso vale também para os poderes destrutivos, insubmissos e contraventores que se atribui ao protagonista: é a própria música que pretende possuir tais atributos.

O labirinto musical que segue é um dos momentos musicais mais interessantes do álbum, no que concerne à transformação, ou até mesmo revelação do personagem-música. O labirinto tem início com frases executadas nos instrumentos de sopro e sintetizador: frases atonais e a princípio desconexas vão se conectando progressivamente. Sobretudo após a entrada do baixo e da bateria, começa a delinear-se uma frase musical evidente, e então todos os instrumentos em uníssono dão ensejo à entrada do refrão: "Clara Crocodilo fugiu, Clara Crocodilo escapuliu". Temos aqui o momento mais consoante de todo álbum: Clara Crocodilo escapa, liberta-se, e a sua liberdade traduz-se musicalmente em consonância, ela revela-se uma música indubitavelmente popular, consoante e até mesmo alegre. A disposição ameaçadora em relação ao ouvinte suaviza-se e transforma-se em pedidos de ajuda acompanhados de provocações bem-humoradas. Em linguagem cinematográfica estamos no momento do filme em que o conflito de alguma forma se resolve e é celebrado o êxito do herói. No caso, a fuga do protagonista e seu desaparecimento em um labirinto.

Contudo, ainda temos o epílogo, quando volta a conjunção de aceleração, tematização e dissonância, e a persona de Arrigo Barnabé retoma a posição de narrador, bem como sua emissão tenso-estrangulada. “Onde andará Clara Crocodilo?” é uma questão que, como já está claro agora, remete ao mesmo tempo ao personagem e à própria música. Se na história narrada essa pergunta indaga a respeito do personagem herói-marginal, ela também é uma indagação a respeito do fim que levará essa música. Mais uma vez a canção aborda sua recepção e seu provável esquecimento: onde estaria esse álbum vinte anos após o seu lançamento? Esquecido e empoeirado em algum sebo? A mesma ambivalência estende-se para os versos seguintes: que Clara Crocodilo esteja em algum lugar escondido, aguardando o momento para assassinar o ouvinte e seus entes queridos refere-se também às canções do álbum, possivelmente perdidas, à espreita de seus ouvintes, aguardando a oportunidade para tomá-los de assalto. Passando ao âmbito psicológico, os versos finais sugerem que ela esteja em nossa mente, e quando despertar, descerá ao nosso coração. Que ela almeje nosso coração, apesar da ameaça implícita, alude também ao desejo de conquistar a simpatia e afeto, o que fica ainda mais evidente quando ela se declara fraternal ao ouvinte "meu irmão", em referência aos versos de Baudelaire. Clara Crocodilo é, afinal de contas, canção, e busca como tal a persuasão e a aceitação do público. 


\section{Considerações finais:}

Para resumir as principais características formais das canções do álbum Clara Crocodilo: 1. Canções que combinam a linguagem musical das vanguardas eruditas do começo do século XX com a linguagem da canção, por meio do uso de módulos e da repetição, articulando assim as duas linguagens. 2. Canções que se valem da inusitada combinação de curva melódica temática com o uso da dissonância, cujo resultado estético é um estado de tensão permanente embalado por figuras rítmicas bem delineadas que se repetem insistentemente. 3. Nesse estado de tensão permanente, euforia e disforia, atração e repulsão são ambiguamente aproximadas, evocando figuras discursivas como a ambiguidade, perversidade e até mesmo o sadismo. 4. A persona incorporada pela voz de Arrigo Barnabé em sua emissão "tenso-estrangulada" assume o papel de narrador, realiza retratos urbanos que abordam a temática da violência, submundo, vício, desilusão amorosa e prostituição. 5. A personagem Clara Crocodilo abarca, no seu espectro de conotações, a figura de um lúmpen proletário transformado em monstro/marginal, e ao mesmo tempo, a própria canção marginalizada no circuito independente, a qual, como bem formulou Garcia $^{84}$, existe mais como potência do que como ato: esquecida num disco empoeirado, aguarda o momento oportuno para conquistar nossos corações.

Podemos retomar aqui um pouco mais dos argumentos de Garcia $^{85}$. Segundo o autor, o foco das canções de Clara Crocodilo, assim como as do primeiro álbum de Itamar Assumpção Nego Dito seria a própria canção; elas realizam um comentário sobre as formas da canção popular brasileira e de sua situação no momento "independente" vivido por esses artistas. Realizando um "salto interpretativo", Garcia argumenta também que a representação da marginalidade nessas canções não convence, não possuem a mesma força do que, por exemplo, o Rap dos anos 1990 de grupos como Racionais MC's e Facção Central. Conforme argumentamos acima, o foco das canções de Barnabé não é exclusivamente a canção, a posição independente ou o recrudescimento da violência urbana, mas tudo isso ao mesmo tempo. No entanto, Garcia tem razão ao chamar a atenção para o distanciamento que há nessa representação. Como a nossa análise pretende ter mostrado, procedimentos como a ironia, o kitsch, a estética "camp" e a ambiguidade sarcástica do narrador incorporado pela persona de Barnabé distanciam-no do objeto da narração distanciamento que se mostra crítico e mesmo por vezes depreciativo. Esse distanciamento se mostra também na posição que Barnabé pretendia galgar no campo da canção: o volume

${ }^{84}$ Walter Garcia. Clara Crocodilo e Nego Dito: dois perigosos marginais? Antíteses (Londrina), v. 8, p. 1036, 2015.

${ }^{85}$ Idem. 
de informações oriundas da esfera erudita mobilizado pelo compositor mostra quão intensamente ele buscou se destacar, se distinguir pela busca da raridade, das informações mais raras e por isso mais nobres no campo da canção. O olhar ao submundo, a agressividade, o "marginal" são representações feitas a partir de uma posição privilegiada no mundo da cultura, que as observa e as trabalha esteticamente, mas à distância.

Que as canções de Clara Crocodilo façam também um comentário sobre a história da MPB não é de espantar, uma vez que a noção de "linha evolutiva" servia a Arrigo como proposta para inovar a forma da canção mediante uma releitura crítica da tradição. Mas haveria alguma conexão entre essa radicalização da proposta tropicalista e o distanciamento irônico/depreciativo ante os problemas sociais representados nas canções? Qual o significado desse paradoxo entre a busca de uma posição privilegiada no mundo cultural e o retrato ambíguo das esferas sociais mais baixas? Agora que já foi feita uma análise das canções, é preciso destrinchar os fios que elas deixaram soltos e usá-las como uma sonda para mergulhar em momentos anteriores da canção. Precisamos detalhar melhor qual o diálogo desse álbum com momentos anteriores da canção popular e quais as linhas traçadas nos modos de representar a ideia de um Brasil moderno.

Os próximos capítulos buscam reconstruir momentos chave na constituição da canção popular brasileira, tendo por objetivo sintetizar, a partir da literatura acadêmica disponível, bem como das próprias canções e outras obras culturais significativas (sobretudo o cinema), quais os sentidos associados a ideia de um Brasil moderno nesses momentos. Contudo, conforme veremos, a ideia de modernidade brasileira esteve sempre atrelada à figura do povo e dos possíveis papeis que ele poderia cumprir nesse processo especialmente em se tratando da canção, forma artística popular por excelência, a qual teve uma proeminência incomum na dinâmica cultural brasileira.

É preciso manter em mente que, apesar da distância temporal desses momentos em relação ao que foi discutido acima, o que se pretende clarificar nos próximos capítulos são determinadas linhas de força presentes na canção enquanto prática de representação. Elas não somente atravessaram todo o século XX como também são até hoje atuantes $\mathrm{e}$ provavelmente permanecerão por muito tempo exercendo um papel decisivo: qual o papel das classes populares na construção de um país moderno? Em que medida a modernização foi associada a superação dos dilemas nacionais? Como se posicionou a canção na esfera pública para a articulação dessas questões? 


\section{Capítulo V: Nacionalização e internacionalização do samba nas décadas de 1920 e 1930}

\section{Introdução}

Este capítulo procura revisitar três autores clássicos dos estudos sobre música popular brasileira (Hermano Vianna, José Miguel Wisnik, e Marcos Napolitano) para averiguar como eles abordaram a questão da ascensão do samba à categoria de música nacional e símbolo da brasilidade por excelência, tanto para o público nacional quanto para o internacional, nas décadas de 1920 e 1930 . Como veremos, a canção e sobretudo o samba enquanto expressão da cultura nacional e símbolo de brasilidade por excelência foi resultado da dinâmica social e política ocorrida nessas décadas. Foi também aí que a introdução do gramofone e da Rádio Nacional fez circular uma cultura popular distinta do folclore, prezado por parte da intelectualidade como fonte de autenticidade cultural para a arte brasileira. $\mathrm{O}$ samba, enquanto gênero mais popularizado da canção, emergiu, então, enquanto símbolo de uma cultura nacional e popular. Mas o popular emerge como portador de ambiguidades: os pobres, os negros, os moradores da favela, seriam o povo carente de cultura, educação, civilidade, um outro perigoso ante o qual são necessários dispositivos pedagógicos e de controle. Ao mesmo tempo, é dele que emana o samba e o carnaval, expressões "autênticas" de um país mestiço. Outra dicotomia que se estabelece diante do popular é a emergente cultura de massas - vista ora como mero entretenimento indisciplinado, ora como espaço para a atuação do artista/intelectual pedagogo. Portanto, este capítulo dedica-se a traçar alguns esquemas referentes à canção nessas décadas, período crítico na formação do Brasil moderno, do qual emergiram símbolos de brasilidade que persistem até os dias de hoje (samba, carnaval, futebol, o mulato...), e da qual surgiram linhas de força que marcaram a prática da canção popular nas décadas posteriores. Ao mesmo tempo, chama-se a atenção para o fato de que a transformação da canção e do samba em manifestações de brasilidade foi realizada não apenas em âmbito nacional, mas também ocorreu conjuntamente com a construção de uma imagem internacional do Brasil.

A discussão a respeito do samba envolve também outras dimensões. Vianna aborda o processo de nacionalização do samba questionando como se deu a sua passagem, de ritmo popular aparentemente desprezado pelas elites e reprimido pela polícia a ritmo celebrado, inclusive internacionalmente, como brasileiro (ou seja, um ritmo não apenas específico de uma determinada classe ou espaço social, mas comum a toda "comunidade" nacional) por excelência (Vianna, 1994). Para o autor, esse processo está intimamente associado à 
transformação da figura do mestiço, de causa do atraso a bastião da originalidade brasileira, a partir da obra de Gilberto Freyre. Wisnik (1983), por sua vez, aborda a relação política por vezes conflituosa entre a intelligentsia musical (Mario de Andrade e Villa-Lobos) e a música popular. Já Napolitano $(2002,2007)$ se debruça sobre a construção da "autenticidade" do samba. Ou seja, a discussão do samba envolve inevitavelmente questões relativas à identidade nacional, centralização do poder do Estado e a relação entre "raças" e classes sociais.

Segue então uma contextualização das décadas de 1920 e 1930, para depois apresentar os principais argumentos dos autores brasileiros em questão. Então, parte-se para a questão da internacionalização da música popular brasileira para finalmente discutir-se a nacionalização e internacionalização do samba enquanto a música popular brasileira por excelência.

\section{Contextualização}

Com a Primeira República ${ }^{86}$, surgiram diversos desafios para a elite social que tomou o poder da coroa. Além da necessidade de redesenhar as instituições políticas brasileiras e o arranjo entre os diversos grupos que disputavam o poder, havia, no plano simbólico, um duplo desafio: inscrever o Brasil em uma nova dinâmica internacional, ao mesmo tempo em que buscava, para si mesma, novas definições de brasilidade. Segundo Schwarcz e Starling, (2015, p. 545), mesmo os nomes de batismo dado aos nascidos na época apontavam para as ambições republicanas: Jefferson, Washington, Franklin...

Um interessante exemplo da interação entre a busca de novos símbolos de brasilidade e a busca de associações com símbolos internacionais de modernidade e cosmopolitismo é a própria bandeira do Brasil: a primeira versão da bandeira, criada no império, aludia às casas de Bragança e Habsburgo, inscrevendo o Brasil no âmbito das casas monárquicas europeias. Estavam nela também os ramos de tabaco e café, os produtos nacionais, aludindo à economia agrário-exportadora do país. Já a bandeira criada por Rui Barbosa e usada apenas nos primeiros dias da república é uma alusão direta à bandeira dos Estado Unidos, aproximando assim a nova república de um novo contexto internacional: o republicanismo. A bandeira, em sua versão atual, criada em 19 de novembro de 1889, recupera a bandeira imperial "traduzindo-a" para a ideologia então moderna e progressista do positivismo: as

\footnotetext{
${ }^{86}$ Em vez de "República Velha", damos aqui preferência à nomenclatura "Primeira República", pois, seguindo o argumento de Schwarcz e Starling (2015, p.601), o adjetivo "velha" implíca juízos de valor atribuídos a esse período, na época do Estado Novo, quando, justamente, se contrapunha o "novo" à indesejável "velha" república. [Onde é advérbio de lugar; quando é advérbio de tempo]
} 
cores das casas de Bragança e Habsburgo passaram a representar o verde das matas e o amarelo do ouro e, no céu estrelado, figura o lema de "Ordem e Progresso".

Uma breve reconstrução da dinâmica social e política da Primeira República pode ajudar a compreender o contexto de criação desses novos símbolos de brasilidade, e, inclusive, como pôde a música popular (sobretudo o samba) ascender a símbolo por excelência da cultura popular brasileira. A Primeira República foi marcada pela descentralização das bases políticas - as forças regionais, como os cafeicultores em São Paulo, os produtores de leite e café em Minas Gerais e os estancieiros do Rio Grande do Sul compunham oligarquias que disputavam o poder, possuindo interesses políticos divergentes (Fausto, 1994, p. 139). Os cafeicultores paulistas dependiam da exportação do seu produto e valeram-se do seu peso político para assegurar a intervenção do governo estadual e federal na proteção do preço do café no mercado internacional de compras estatais (Fausto, 1994; Schwarcz e Starling, 2015). Já os estancieiros do Rio Grande do Sul dependiam do mercado interno para o escoamento da sua produção, sobretudo a carne seca, assim como a produção agrária de Minas Gerais também dependia do mercado interno. Esses três estados compunham as principais forças regionais a exercer pressão descentralizadora na primeira república. Já os militares compunham a principal força que reivindicava a centralização do poder: o movimento tenentista e a Coluna Prestes foram eventos que marcaram a oposição ao sistema político das oligarquias regionais. As forças militares tiveram um papel decisivo na revolução de 1930 (Idem), que depôs a Primeira República.

Havia, portanto, o desafio de conciliar a força política (divergente) das oligarquias com as aspirações de fortalecer o poder central da república. Tênue equilíbrio foi conquistado com a assim chamada política dos governadores (a representação parlamentar de cada estado correspondia ao grupo regional dominante (Fausto, 1994, p. 147)), o sistema político do coronelismo (a compra de votos em troca de favores ou a simples fraude dos votos pelo "coronel" local) e a alternância da influência de São Paulo e Minas Gerais no mandato presidencial (Fausto, 1994; Schwarcz e Starling, 2015). Mas não apenas os militares encamparam a insatisfação com o sistema político. A primeira república foi marcada também pela urbanização, industrialização e o surgimento das primeiras greves e movimentos operários. Porém, o mais marcante conflito social da época foi a guerra de Canudos, registrada na obra de Euclides da Cunha. O arraial de cerca de 20 mil pessoas, liderado por Antônio Conselheiro, reunia populações sertanejas alvejadas pela pobreza e falta de terra. Famílias que lá chegavam recebiam um lote de terra para viver e trabalhar, ao passo que a pregação mística de Conselheiro condenava a república em nome da monarquia. 
Dizimada pelas forças republicanas, a cidade de Canudos repercutiu como símbolo do “outro" Brasil (Schwarcz e Starling, 2015). Do ponto de vista das elites regionais, este era o Brasil atrasado, pauperizado, retrógado, ignorante e "degenerado". Ironicamente, a vegetação que recobria os montes na região de Canudos viria a emprestar seu nome para as ocupações urbanas dos morros cariocas pela população pobre: favela (Schwarcz e Starling, 2015, p. 578). Não é mera coincidência: as populações urbanas pobres, em geral negros e mestiços, também figuravam como o "outro" degenerado. Ainda assim, já na primeira república esse "outro" foi também vislumbrado como o Brasil autêntico, o possível elemento chave para a união social, política e simbólica da nação: o sertanejo, para Euclides da Cunha, é antes de tudo um forte. A semana de arte moderna de 1922 também elegeu a cultura popular rural (o "folclore") como a fonte de uma arte legitimamente nacional (Wisnik, 1983) recuperando a figura do indígena (sobretudo retrabalhando a antropofagia em estratégia cultural), a linguagem vernácula popular (veja-se a prosa de Mário de Andrade) bem como os ritmos musicais (importante salientar: do folclore rural) como fonte da nova música (erudita) legitimamente nacional.

A população pobre urbana, que até os dias atuais possuem na favela a sua imagem mais emblemática, permaneceram em grande medida como o "outro" indesejável, o polo negativo da sociedade. Pobreza e exclusão social foram acompanhadas pela discriminação racial: autores como Nina Rodrigues e Silvio Romero procuraram explicar esses problemas sociais em termos de degeneração biológica. Mesmos modernistas como Mário de Andrade viram com desconfiança a música que emergia dos cortiços e favelas (voltaremos a este ponto). Contudo, contra todas as expectativas, poucos anos após a revolução de 1930 o samba é elevado à categoria de música popular nacional por excelência, o carnaval torna-se a festa nacional patrocinada inclusive pelo Estado Novo, e a obra de Gilberto Freyre de 1933 logra ressignificar o mestiço: de fonte do atraso para fonte do Brasil enquanto civilização única e original, a figura da potência e elo de ligação da nação. Como pôde o samba e o mestiço passarem, em poucos anos, de raça degenerada e ritmo maldito a símbolo e orgulho nacionais? Eis o "mistério do samba" estudado por Hermano Vianna.

\section{Vianna e o mistério do samba}

O livro de Hermano Vianna O mistério do samba (1994) aborda justamente a transformação do samba em ritmo símbolo da brasilidade, em elemento central da identidade nacional tanto para o público nacional quanto para o internacional. O que há de misterioso nesse processo é a narrativa - segundo o autor tantas vezes repetida - de descontinuidade. 
Num primeiro momento, o samba era reprimido: possuir um violão era motivo suficiente para levar um mulato à cadeia ou acabar com a reputação de um homem branco (o autor oferece muitos exemplos, os melhores deles sendo alguns trechos do romance $O$ triste fim de Policarpo Quaresma, de Lima Barreto). Samba seria música restrita aos cortiços e favelas, desprezado pela elite. Num segundo momento, sem que se explique como se deu a passagem, o samba e a música popular se generalizaram, conquistaram as camadas médias e superiores, e passaram a simbolizar a cultura brasileira em geral no âmbito nacional e internacional. Nas palavras de Antônio Cândido:

\footnotetext{
na música popular ocorreu um processo equivalente de "generalização" e "normalização", só que a partir das esferas populares, rumo às camadas médias e superiores. Nos anos 30 e 40, por exemplo, o samba e a marcha, antes praticamente confinados aos morros e subúrbios do Rio, conquistaram o País e todas as classes, tomando-se um pão-nosso quotidiano de consumo cultural. Enquanto nos anos 20 um mestre supremo como Sinhô era de atuação restrita, a partir de 1930 ganharam escala nacional homens como Noel Rosa, Ismael Silva, Almirante, Lamartine Babo, João da Bahiana, Nássara, João de Barro e muitos outros. Eles foram o grande estímulo para o triunfo avassalador da música popular nos anos 60 , inclusive de sua interpenetração com a poesia erudita, numa quebra de barreiras que é dos fatos mais importantes da nossa cultura contemporânea e começou a se definir nos anos 30, com o interesse pelas coisas brasileiras que sucedeu ao movimento revolucionário. (SOUZA, 1989, p. 198).
}

Ao mistério do samba, Vianna agrega o "mistério da mestiçagem": considerada a causa dos males nacionais, ela passou, sobretudo a partir da publicação de Casa Grande e Senzala, em 1933, a ser a garantia da originalidade e força da civilização brasileira.

Vianna procura resolver o mistério do samba a partir de um encontro ocorrido em 1926, num bar no centro do Rio de Janeiro. Gilberto Freyre, Sergio Buarque de Holanda, Prudente de Morais, Villa-Lobos e Luciano Gallet passaram a noite com os sambistas Patrício Teixeira, Donga e Pixinguinha. Se o samba era um ritmo maldito e reprimido, o que faziam esses intelectuais pertencentes à elite (branca) num bar com músicos populares, pobres e negros? Para o autor, esse encontro, anotado no diário de Freyre, mas que não fora noticiado em lugar nenhum como algo extraordinário, é indicativo de uma longa história de mediações culturais entre a elite e as classes populares. Vianna transporta para a história do samba o argumento de Freyre de que, entre a casa grande e a senzala, havia trocas em ambas as direções, gerando formas culturais em que os contrários se equilibravam. Também argumenta que o Brasil é uma sociedade contraditória, onde mesmo nos momentos em que 
o repúdio à cultura nacional e popular parecia reinar absoluto, no seio das elites, havia interesse e espaço para a cultura popular: Rui Barbosa recriminou abertamente a apresentação do "Corta-Jaca" de Chiquinha Gonzaga nas recepções presidenciais, mas foi às lágrimas com os versos de Catulo da Paixão Cearense numa reunião em sua própria casa (Vianna, 1994, p. 46). O samba era reprimido pela polícia, sim, mas também aceito e apreciado: o poeta Manuel Bandeira era frequentador da casa da Tia Ciata ${ }^{87}$ ao passo que sambistas como João da Baiana eram convidados para animar festas de senadores (Vianna, 1994, p. 114).

A grande diferença, na passagem da Primeira República para o Estado Novo em contraposição aos outros momentos em que também haviam interpenetrações culturais entre as camadas sociais, foi que nesse momento houve a necessidade política de estabelecimento de novos símbolos nacionais que abarcassem o conjunto da população. Junto a isso, a introdução de novas tecnologias permitiu a difusão de ideias homogeneizadoras a respeito do significado de "nacional" a partir de um centro difusor: a Rádio Nacional, inaugurada em 1936 no Rio de Janeiro e a indústria do disco que também se instalou na capital federal. Embora tais desenvolvimentos tenham se dado sobretudo a partir da era Vargas, já na década de 1920 o modernismo propôs uma redescoberta simbólica do Brasil. Após a revolução de 1930, o Estado Novo contrapôs-se às oligarquias regionais também no plano cultural, promovendo símbolos que unificavam a nação em torno do seu projeto: o Brasil mestiço, país do carnaval e do samba. Na década de 1940, Carmen Miranda e Walt Disney projetaram essa imagem do Brasil no exterior.

É preciso ressaltar, no entanto, que além da atuação de intelectuais como Freyre e mesmo da atuação do Estado Novo, havia também motivos estruturais para que a canção popular viesse a exercer um papel destacado na cultura brasileira: o analfabetismo. Durante a primeira república, a participação nas eleições variou entre aproximadamente 1\% e 5\% da população, e um dos fatores de ser tão limitada era o pré-requisito de ser alfabetizado para votar (Fausto, 1994). O sociólogo Renato Ortiz argumenta a respeito das possíveis causas da surpreendente interpenetração entre as culturas erudita e popular, no Brasil, que fez da canção popular, nas palavras de Lilian Schwarcz: "a mais eficiente linguagem produtora de conhecimento sobre o Brasil e acessível a toda a população" (Schwarcz e Starling, 2015).

\footnotetext{
${ }^{87}$ A casa da Tia Ciata foi um espaço decisivo na criação do samba moderno no início do século XX no Rio de Janeiro, citado por praticamente todos os autores que trabalham sobre o tema. Lá se reuniam os músicos acima citados por Vianna, além de nomes como o poeta Manuel Bandeira. "Tia" era o apelido dado às mulheres negras baianas que trabalhavam vendendo quitutes no Rio de Janeiro. Ciata era uma dessas mulheres, e sua casa, como veremos mais adiante com Wisnik, era um espaço de importante encontros e mediações culturais, onde foi composto o primeiro samba gravado "Pelo Telefone", de Donga.
} 
Segundo Renato Ortiz, a introdução do capitalismo no Brasil e o surgimento de um mercado cultural de massas deu-se em condições muito distintas do que na Europa. Lá, já no século XIX, havia um mercado cultural de massas. A esse respeito, é sugestiva a seguinte passagem de Ortiz:

O índice de alfabetização [na França], que era em torno de 30\% no ancien regime, sobe para $60 \%$ em 1860 para atingir $90 \%$ em 1890. A produção média anual de livros no século anterior era em torno de 600 a 800 títulos; em 1850 ela passa para 7658 e em 1889 para 14 849. [...] Na Inglaterra as mudanças caminham na mesma direção. Em 1841 o número de pessoas alfabetizadas já atinge 59\%; em 1900 ele é de $97 \%$. (ORTIZ, 1988, p. 24)

Quadro muito distinto do Brasil, onde o índice de analfabetismo permaneceu elevado século XX adentro: 1890 - 84\%, 1920 - 75\%, 1940 - 57\% (ORTIZ, 1988, p. 28). Ou seja, mesmo até meados do século XX a maioria da população estava excluída da cultura letrada! Desse modo, todas as tentativas de criar uma identidade cultural no âmbito literário estava fatalmente circunscrita à minoria ${ }^{88}$. Portanto, num país majoritariamente analfabeto, a canção foi provavelmente o instrumento mais acessível de disseminação cultural.

Houve nos anos 1930, segundo Candido ${ }^{89}$, um processo de ampliação e normalização na vida cultural brasileira de elementos renovadores surgidos na década de 1920. Um processo de "normalização" de elementos que, na década anterior, eram percebidos como uma vanguarda provocadora. O modernismo musical foi assimilado com a entrada de VillaLobos ao ministério Capanema, cujo edifício foi projetado por Lucio Costa e Niemeyer. A prosa vernácula brasileira, recurso estilístico modernista em Mário de Andrade, encontrou consolidação e difusão em nomes como Graciliano Ramos e Jorge Amado. Essa consolidação e difusão foi acompanhada de uma preocupação cada vez maior com as "coisas nossas": a literatura regional, a prosa brasileira, os problemas sociais (anos 1930 foi a década dos grandes ensaios interpretativos do Brasil, com Casa Grande e Senzala, em 1933, de Gilberto Freyre, Raizes do Brasil, em 1936, de Sérgio Buarque de Holanda e Formação do Brasil Contemporâneo, em 1942 , de Caio Prado Junior). O que distingue a canção e,

88 "Todos os testemunhos e as análises apontam que, até a década de 30, a produção e o comércio de livros no Brasil eram praticamente inexistentes em termos de mercado. A tiragem de um romance era em média de mil exemplares, e um best-seller como Urupês vendeu, em 1918, oito mil cópias. Em São Paulo, entre 1900 e 1922, publicaram-se somente 92 romances, novelas e contos, ou seja, uma média de sete livros de literatura por ano". (ORTIZ, 1988, p. 28)

${ }^{89}$ Antonio Candido de Mello e Souza. A revolução de 1930 e a cultura. Novos estudos CEBRAP, v. 2, n. 4, p. 27-32, 1984. 
sobretudo, o samba dessas outras manifestações que encontraram normalização e difusão na década de 1930 é sua origem popular, de baixo, que foi galgando penetração em camadas superiores num processo de mediação cultural que culminou no "mistério do samba" estudado por Vianna: o samba marginalizado, de grupos sociais também marginalizado transformou-se em símbolo popular de brasilidade por excelência, coisa nossa, num momento em que havia a vontade política e os recursos tecnológicos (fonografia e rádio) para a sua difusão em âmbito nacional e internacional.

Mas a relação entre samba, mestiçagem e projeto de uma nova nação no Estado Novo não foi livre de conflitos (tema do próximo item). A relação ambígua entre o samba e a ordem, bem como a situação precária das populações pobres urbanas, convivendo com o limiar entre o lícito e o ilícito é notada com muita ironia no samba "Coisas nossas" de Noel Rosa.

"Coisas nossas" de Noel Rosa, 1931,

\author{
Malandro que não bebe, \\ Que não come, \\ Que não abandona o samba \\ Pois o samba mata a fome, \\ Morena bem bonita lá da roça, \\ Coisa nossa, coisa nossa \\ O samba, a prontidão \\ E outras bossas, \\ São nossas coisas, \\ São coisas nossas! \\ Baleiro, jornaleiro \\ Motorneiro, condutor e passageiro, \\ Prestamista e o vigarista \\ E o bonde que parece uma carroça, \\ Coisa nossa, muito nossa
}

O malandro e o samba não são simples exaltações do prazer e do ócio, mas expedientes para enfrentar a fome. A última estrofe é especialmente significativa da ambiguidade e permeabilidade entre ordem e transgressão ao arrolar no mesmo páreo profissionais urbanos e o vigarista, o bonde e a carroça. 


\section{Wisnik e Napolitano}

Contudo, a relação entre membros intelectuais da elite, como Mário de Andrade e Villa-Lobos, com a música popular urbana, sobretudo o samba, não foi tão pacífica quanto o texto de Vianna dá a entender. Não por acaso o próprio autor assume seu "Gilberto Freyre centrismo" na interpretação da ascensão do samba à categoria de música nacional: Freyre é amplamente criticado por subsumir o aspecto conflitivo das relações entre negros, brancos e indígenas na sociedade escravocrata brasileira em nome de um "equilíbrio dos contrários" numa sociedade mestiça. $\mathrm{O}$ argumento de Vianna também se deixa levar pelo ideal de uma sociedade brasileira mestiça na qual os conflitos de raça e classe se apaziguariam.

Em sentido oposto, José Miguel Wisnik trabalhou a relação de Mário de Andrade e Villa-Lobos com a música popular nas décadas de 1920 e 1930. O autor argumenta que compositores eruditos da escola nacionalista, como Villa Lobos e Guarnieri, informados em larga medida pelas concepções de Mário de Andrade, valeram-se do material popular em suas composições (WISNIK, 1982, p. 130), mas não da música popular urbana que começava a se disseminar pelo gramofone, vista como impura, indisciplinada e indigna, mas sim a música popular oriunda das tradições rurais, vistas sob a perspectiva do folclore. Este seria a fonte e a raiz a partir da qual a música erudita deveria trabalhar, estilizar, "elevar", tendo em vista a afirmação da arte nacional.

[...] o povo homenageado e imaginado por esses músicos, o povo bom-rústico ingênuo do folclore, difere drasticamente de um outro que desponta como antimodelo: as massas urbanas, cuja presença democrático anárquica no espaço da cidade (nos carnavais, nas greves, no todo-dia das ruas), espalhada pelos gramofones e rádios através do índice do samba, provoca estranheza e desconforto. (WISNIK, 1982, p.131)

Havia, portanto, uma separação entre a boa música, fruto da aliança entre a arte erudita e as formas regionais, rurais e comunitárias, e a música má, fruto do avanço da modernidade capitalista, tanto na forma da música popular urbana e comercial quanto nas formas das vanguardas europeias. Ante essas tendências modernas, procurava-se resguardar, pela aliança do popular-folclórico com o erudito, a autonomia de uma arte legitimamente nacional. ${ }^{90}$

90 "Está formada a cadeia conflitual bem típica da discussão brasileira: a conjunção entre o nacional e o popular na arte visa à criação de um espaço estratégico onde o projeto de autonomia nacional contém uma posição 
Ainda segundo Wisnik, essa ideologia de uma música nacional, defendida por expoentes do modernismo como Villa-Lobos e Mário de Andrade, visava um projeto de elevação estético-pedagógico do país, uma pedagogia que emanava do artista a serviço do Estado-nação. Este seria o orquestrador do encontro entre o povo enquanto fonte da cultura autêntica com o povo enquanto massa analfabeta, supersticiosa e indolente. Havia, junto da cisão entre a música popular, fonte de virtudes, de um caráter nacional adormecido e da música popular urbana, uma cisão entre o povo como nação adormecida e o povo vulgar "sem cultura". O artista/intelectual seria o agente da superação pedagógica dessa cisão:

\begin{abstract}
Em alguns casos (e é o caso de Mário de Andrade) o intelectual quer ser o orquestrador de sua própria oscilante superioridade/inferioridade frente à cultura popular, e se projeta imaginariamente num ponto-de-epifania de onde divisa o encontro das águas do povo opaco e do povo luminoso, redimidos da sua dualidade numa nova unidade transparente e transformadora. [...] Através dessa curiosa operação desalienante, em que o povo-nação recupera o "caráter" que lhe falta, o intelectual letrado-pedagogo fica no centro imaginário, de onde procura reger o coro nacional, levando-o à unidade harmônica. (WISNIK, 1983, p.146)
\end{abstract}

O artista deveria "atrair os broncos à civilização" "91, sanar a falta de caráter nacional, e a música seria $o$ lugar de manifestação da linguagem popular original, só ela poderia orquestrar uma sociedade dividida e mediar a passagem de uma sociedade em potencial para uma sociedade efetiva ${ }^{92}$. Mas o projeto de "dominar o popular em benefício da totalidade" no âmbito do Estado Novo, era a todo momento desmentido pela música popular que, alheia às concepções pedagógicas, se espalhava pela via do mercado.

A canção popular urbana, embora não dotada de um projeto pedagógico ou da elevação formal exigida pela música erudita, possuía uma dinâmica própria e, o que não é

defensiva contra o avanço da modernidade capitalista, representada pelos sinais de ruptura lançados pela vanguarda estética e pelo mercado cultural" (Wisnik. 1982, p. 134).

${ }^{91}$ Veja-se o pronunciamento feito em 1941 por um membro da Rádio Ministério da Educação, transcrito por José Miguel Wisnik: “A nosso turno adiantamos que, (...) todos os indivíduos analfabetos, broncos, rudes de nossas cidades são muitas vezes pela música atraídos à civilização. (...) dia virá, estamos certos, que o sensualismo que busca motivos de disfarce nas fantasias de carnaval, seja a caricatura, o fantoche, o palhaço, o alvo ridículo desta festa pagã. Enquanto não dominarmos esse ímpeto bárbaro é prejudicial combatermos no broadcasting o samba, o maxixe e os demais ritmos selvagens da música popular. (...) o samba, que traz na sua etimologia a marca do sensualismo, é feio, indecente, desarmônico e arrítmico. Mas paciência: não repudiemos esse nosso irmão pelos defeitos que contém. Sejamos benévolos; lancemos mão da inteligência e da civilização. Tentemos devagarinho torná-lo mais educado e social. Pouco nos importa de quem ele seja filho." (Wisnik, 1982, p. 135-136).

92 "Mas o poder da música, veículo privilegiado de transmissão social, é multiplicado ainda mais no Brasil pela sua ampla penetração, pelo fato de ser o lugar de produção de uma linguagem popular original (a música popular é a “criação mais forte e a caracterização mais bela de nossa raça', dizia Mário de Andrade)" (Wisnik, 1982, p. 146). 
desimportante, carregava as marcas dos espaços sociais onde era produzida. Vejamos uma ilustrativa fábula recuperada pelo historiador Marcos Napolitano, na qual são apresentados os lugares e a genealogia da canção popular numa espécie de mito de origem da canção:

Em 1933, numa revista-opereta de sucesso intitulada Canção brasileira (de Luis Iglesias e Miguel Santos, com canções de Henrique Vogeler), a personagem-título, filha da aristocrática modinha e do elegante Lundu, é raptada, ainda recém-nascida, pelo trio formado pela Flauta, pelo Cavaquinho e pelo Violão. Eles levam a Canção para o morro, acreditando que ela seria mais feliz ao lado do povo do que nos salões aristocráticos. No morro ela conhece o Samba, filho do maxixe. Os dois crescem juntos e se enamoram. Anos depois, a Canção é reencontrada pela mãe, e a paixão pelo Samba é ameaçada pelo Tango, latino sedutor. A modinha e o Tango convencem a Canção a descer o morro e voltar para a cidade, seu "verdadeiro lugar", apesar da paixão que ela nutre pelo Samba. Os personagens do morro ficam inconformados e, ao final, o Samba consegue reconquistar a Canção brasileira, harmonizando o morro e a cidade. (NAPOLITANO, 2007, p.9)

É interessante notar, na fábula, como os gêneros musicais configuram uma espécie de mapa simbólico da cidade, no caso, a cidade do Rio de Janeiro, que, na primeira metade do século XX, concentrou em si as instituições do mercado musical nacional. Contudo, no plano simbólico, a canção de certo modo atravessa diversos espaços sociais conflitantes (como mostra o final feliz da fábula). Enquanto emblema de uma identidade cultural brasileira, a canção era reivindicada e disputada por diversos grupos. De um lado, o Estado Novo buscava a legitimidade na imagem do popular e, ao mesmo tempo, procurava disciplinar essas manifestações populares por meio do "samba cívico": temas de elogio à nação e às qualidades do povo que "trabalha cantando", ou seja, que se deveria submeter alegremente à disciplina do trabalho. Do outro lado, classes populares marginalizadas, sobretudo os negros, buscavam pela via musical uma forma de reconhecimento de sua cidadania: “[...] o Estado busca legitimação na imagem do popular e o popular busca cidadania no reconhecimento oficial, num jogo de mimetismos carnavalescamente espelhados, onde ambos se engrupem mutuamente" (Wisnik, 1983, p. 175).

Mas, ainda que, como emblema do nacional, a música popular fosse reivindicada por diversos grupos, persistia a questão dos diversos espaços sociais que não se deixavam misturar, tanto no plano social concreto quanto no plano simbólico. Wisnik, recuperando a história da casa da Tia Ciata como metonímia da vida cultural brasileira, monta o seguinte espectro de espaços sociais, dos mais nobres aos mais populares: a sala de concerto, o sarau, 
o salão de baile, o quintal de samba e o terreiro de candomblé. Espaços hierarquizados no plano simbólico, mas que "vazavam sinais em ambas as direções". Ou seja, embora as classes e os espaços sociais estivessem hierarquicamente segregados, havia mediações culturais entre eles, como Vianna nos mostrou.

Outro fator que promoveu a especial mobilidade da canção popular urbana e comercial advém do fato que, uma vez mediada pelos meios de reprodução fonográfica, ela adquire a capacidade de circular para além dos seus espaços sociais de produção, permeando a hierarquia e o mapa simbólico da cidade, de tal forma que o samba, oriundo de espaços e de grupos sociais marginalizados pôde, com o surgimento da fonografia no Brasil, elevarse ao status de música nacional. Nos anos de 1940 e 1950, a difusão das canções populares e, em especial, do samba, como o gênero nacional e popular por excelência, outrora restrita a seus espaços originais de produção, mas ainda carregando em si os seus códigos culturais, teve sua capacidade de penetração social multiplicada pela Rádio Nacional, criada em 1936. Nos anos do auge da rádio, persistiu a contradição entre uma concepção pedagógica dos meios de comunicação - o projeto civil-pedagógico encampado pelo Estado-Novo - e a existência de programas voltados ao entretenimento das classes populares (NAPOLITANO, 2007, p.52).

Pode-se notar nesse conjunto de questões a respeito da canção popular, nas décadas de 1920 e 1930, que essa forma musical foi abordada por expoentes da elite cultural brasileira dentro do binômio "expressão das massas" (legítima ou ilegítima) e "educação das massas" (formação de um gosto legítimo e introjeção de valores cívicos). Assim como Mário de Andrade via no popular a raiz e a fonte das formas autenticamente nacionais e dignas, e, ao mesmo tempo, a fonte de formas impuras, indignas e vulgares, nas décadas posteriores, consolidou-se uma nova representação do popular legítimo contra o popular vulgar. Mas não foi o folclore rural que se firmou como o autenticamente popular, mas sim a canção e, em especial, o samba.

\section{Noel Rosa e Wilson Batista}

As questões levantadas acima a respeito da canção manifestavam-se não apenas no debate feito pelas camadas intelectuais; nos próprios sambas é possível identificar os conflitos a respeito da posição da canção popular, na cultura nacional que emergia das novas instituições políticas e tecnologias da década de 1930. Conflitos não apenas a respeito da posição da canção, mas também das classes populares, ao qual ela estava associada e muitas vezes representava. 
Conforme observou-se no trabalho de Vianna, a elevação do samba a ícone de brasilidade deu-se nos anos 1930, conjuntamente com a reapreciação da figura do mestiço, cujo grande amparo foi a obra Casa grande e senzala de Freyre. Mestiço é o produto da miscigenação, fato que, desde que o Brasil se preocupou em escrever a sua própria história e construir uma identidade, foi tido como a característica nacional mais marcante ${ }^{93}$ : se, na virada do século XIX para o XX, ainda persistia a ideologia do branqueamento e da miscigenação como mácula, nos anos 1930, o samba, a feijoada e a capoeira tornaram-se ícones da brasilidade, da singularidade brasileira, e modelos de uma pretensa democracia racial.

Contudo, essa passagem não foi uma simples transformação de um polo a outro, na qual os elementos da fase anterior estariam completamente superados no segundo momento. A figura do malandro, indissociável do samba, do carnaval, da festa e do popular, concentra as dicotomias e contradições da frágil posição do samba e do popular. A dialética da malandragem, segundo Antonio Candido, é um princípio estrutural da sociedade brasileira ${ }^{94}$ na primeira metade do século XIX, mas certamente também é sugestivo para o momento em questão. Trata-se da dialética entre ordem e desordem, entre a lei e a transgressão, em que um polo se alimenta do outro, e pode-se facilmente deslizar de um para o outro. O malandro é a figura por excelência do trânsito dúbio entre o lícito e o ilícito, da recusa ao trabalho regular e da criminalidade potencial. Na sua negação da moral do trabalho e da conduta cívica exemplar, o malandro traz consigo o elogio da dança, da bebida, do lúdico, do prazer, da orgia: o "orgulho em ser tão vadio" é a afirmação do ócio, uma conquista para a população em condições precárias que, em 1930, estava apenas algumas décadas depois do fim da escravidão ${ }^{95}$. O malandro é o reverso da figura do operário e vice-versa (Idem). A canção "Lenço no pescoço", de Wilson Batista, é um dos mais clássicos retratos da figura de um malandro no samba da década de 1930. Transcrevemos abaixo um trecho dela:

“Lenço no pescoço", 1933, Wilson Batista

\footnotetext{
${ }^{93}$ Lilia Schwarcz. Complexo de Zé Carioca: notas sobre uma identidade mestiça e malandra. Revista Brasileira de Ciências Sociais, v. 29, n. 10, p. 49-63, 1995.

${ }^{94} \mathrm{O}$ ensaio de Candido sobre o romance Memórias de um Sargento de milícias, de Manuel Antônio de Almeida, elege a dialética da malandragem como o princípio estrutural de organização da sociedade do Brasil urbano da primeira metade do século XIX, período retratado no romance. Ainda assim, essa dialética certamente é significativa para as décadas de 1920 e 1930, como vimos nos trabalhos de Schwarcz, Vianna, Wisnik e Napolitano.

95 José Miguel Wisnik. Algumas questões de música e política no Brasil. Em: José Miguel Wisnik. Sem receita: ensaios e canções. São Paulo: Publifolha, 2014.
} 


\author{
Meu chapéu do lado \\ Tamanco arrastando \\ Lenço no pescoço \\ Navalha no bolso \\ Eu passo gingando \\ Provoco e desafio \\ Eu tenho orgulho \\ Em ser tão vadio \\ Sei que eles falam \\ Deste meu proceder \\ Eu vejo quem trabalha \\ Andar no miserê \\ Eu sou vadio \\ Porque tive inclinação \\ Eu me lembro, era criança \\ Tirava samba-canção \\ Comigo não \\ Eu quero ver quem tem razão
}

A canção de Wilson Batista é exemplar na construção de um personagem. Começa com a descrição de aspectos visuais do personagem como um olho que escrutina de cima a baixo: o chapéu, o tamanco, o lenço, a navalha. Depois, uma série de verbos descrevem o movimento do personagem, o passo, o gingado, a provocação, o desafio. Tudo nele é objeto de sutis alterações, pequenas adaptações que apontam sua constituição ambígua: o chapéu do lado, o tamanco arrastado, o passo gingado, a navalha no bolso indica que ele é potencialmente perigoso ${ }^{96}$. A segunda estrofe vem justificar a atitude do malandro e seu orgulho em ser vadio: quem trabalha anda na miséria e ele reafirma sua inclinação para o ócio, o samba, a festa, o desafio à ordem. Interpretada na voz de Silvio Caldas, a canção é um perfeito exemplo da tematização (a curva da entoação) enquanto modo de concretizar uma ideia na canção. O gingado da curva melódica temática se arrasta, alonga-se numa disposição preguiçosa, ociosa, vadia, ao passo que a interpretação de Caldas é rica em glissandos, onde a voz escorrega de uma nota a outra.

96 Em seu curso oferecido para a graduação (2015) no IEB-USP, Walter Garcia analisou essa canção. Ele chamou a atenção para o elemento "lenço no pescoço". Segundo o professor, o lenço de seda era uma espécie de dispositivo de segurança entre os malandros, uma vez que a seda protegia o pescoço do corte da navalha no caso de uma briga, pois o tecido da seda, de alguma forma, faz o fio da navalha escorregar, e impede o corte. 
Como é sabido, essa canção iniciou uma batalha entre Batista e Noel Rosa, na qual cada um criou canções em resposta ao outro, contradizendo-o praticamente verso por verso. Para além da anedota de uma disputa musical entre dois sambistas, a disputa é significativa de distintos papeis atribuídos ao malandro por cada um deles, assim como do lugar social que o samba deveria ocupar. Ainda que Noel Rosa, arquétipo do sambista boêmio brasileiro, esteja longe de qualquer ética moralista, na disputa contra Wilson Batista ele defende a todo momento o sambista como figura digna de respeito e admiração, não como exemplo de cidadania, mas como talentoso produtor de um feitiço decente. A mais famosa canção produzida por Noel Rosa nessa disputa foi "Feitiço da Vila", da qual transcrevemos um trecho:

"Feitiço da vila", 1934, Noel Rosa,

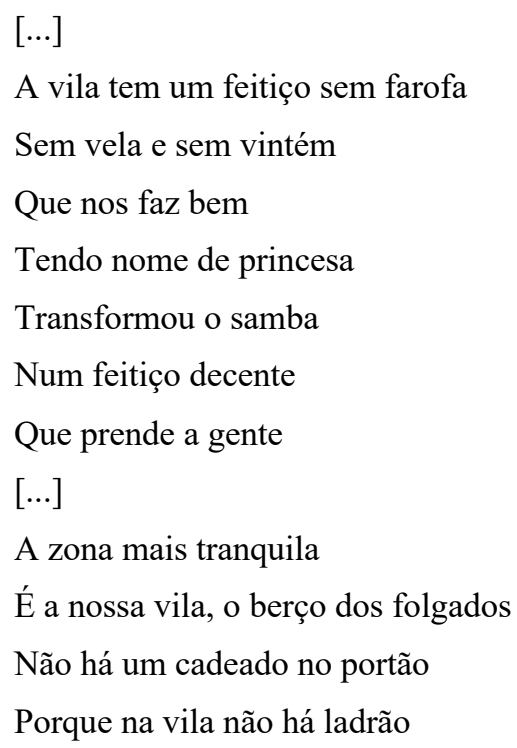

A canção de Noel logra conjugar o samba, a predileção pela noite, festa e ócio com a "decência", um feitiço decente expurgado dos elementos africanos (vela e farofa do candomblé), uma zona onde boemia, bacharel e tranquilidade andam de mãos dadas. O que se nota nessa famosa disputa entre sambistas é novamente a dicotomia entre o popular potencialmente perigoso, o "outro" das favelas e da malandragem de um lado, e do outro, o popular assimilável à totalidade, boêmio mas ainda assim decente, brasileiro.

\section{Internacionalização}

O argumento dos autores, visto acima, aborda o processo de transformação do samba em ritmo nacional de uma perspectiva sobretudo "nacional": nele são privilegiados os 
fenômenos internos ao país nesse processo. O que não equivale a dizer que os autores ignorem ou subestimem a importância de dinâmicas internacionais: sobretudo Vianna faz uma discussão atenta de processos que se passam nos Estados Unidos e na Europa, os quais contribuíram para a transformação do status simbólico conferido aos negros, mestiços e ao samba. A saber: a antropologia cultural de Franz Boas nos Estados Unidos (a qual influenciou diretamente Gilberto Freyre) bem como o interesse das vanguardas europeias do início do século XX pela arte africana (o que certamente aguçou a sensibilidade dos modernistas brasileiros para a arte indígena e afro-brasileira).

No entanto, os artigos reunidos no volume Brazilian Popular Music and Globalization (Perrone; Dunn, 2002) trabalham diretamente a questão da música popular brasileira e a internacionalização (compreendida aqui polissemicamente como: imitação, adaptação ou apropriação de elementos culturais não apenas no eixo norte-sul, mas também da diáspora do "atlântico negro"). Segundo Perrone e Dunn, os dois momentos mais importantes em termos de internacionalização da música popular brasileira foram Carmen Miranda (década de 1940) e a Bossa Nova (década de 1960). No primeiro, a política de boa vizinhança do governo americano no contexto da segunda guerra mundial promoveu a aproximação cultural entre a América Latina e os EUA: Walt Disney realizou dois filmes que promoviam o Brasil (inclusive o samba e o malandro como símbolos brasileiros) Saludos Amigos e The Three Caballeros (1943, 1945), ao passo que Carmen Miranda tornou-se estrela da Broadway, chegando a ser a atriz mais bem paga dos EUA. Já a bossa nova seria reflexo de um momento de confiança do Brasil em seu processo de modernização e desenvolvimento: figuras como Tom Jobim, João Gilberto e Vinícius de Morais conquistaram fama mundial (“Garota de Ipanema” é nada menos que a segunda música mais gravada no mundo), sucesso comercial e interesse por parte dos jazzistas americanos. Em 1959, foi lançado o filme Orfeu Negro de Marcel Camus, o qual, segundo os autores, foi a obra mais importante já realizada na construção de uma imagem do Brasil no exterior, imagem fortemente vinculada ao negro, ao carnaval e à música popular (incluíndo aí a bossa nova).

Podemos nos deter por um momento sobre Carmen Miranda e o filme Orfeu Negro para refletir sobre o significado desses dois eventos no processo de internacionalização de uma imagem brasileira (retomamos aqui os argumentos apresentados nos artigos de Caetano Veloso e Charles A. Perrone). Segundo Caetano Veloso (2002), Carmen Miranda é, ao mesmo tempo, a caricatura e o raio $\mathrm{X}$ da cultura brasileira, motivo de orgulho e vergonha, um estrondoso sucesso e uma paródia de si mesma, o que a aproxima do olhar que o 
tropicalismo, décadas mais tarde, lançou sobre o Brasil. O motivo dessa ambiguidade da figura de Carmen Miranda advém do fato de, por um lado, ela ser uma artista competente, cantora de qualidade técnica, que logrou articular elementos culturais brasileiros numa mensagem estética universalmente legível. Por outro lado, ela é o paroxismo do autoexotismo, sua figura é o kitsch por excelência, a grande manifestação da cultura brasileira "para gringo ver". A figura de Carmen Miranda concentra, portanto, as ambiguidades da internacionalização da imagem brasileira via canção popular: ao mesmo tempo que é motivo de orgulho, há sempre o risco do auto-exotismo, do kitsch e da perda a "autenticidade". A canção "Disseram que voltei americanizada" é uma resposta exatamente às acusações de que ela havia cometido uma "falsificação" da cultura do samba.

Questões muito semelhantes são levantadas no artigo de Perrone "Myth, Melopeia and Mimesis: Black Orpheus, Orfeu and the Internationalization in Brazilian Popular Music", que trata do filme Black Orpheus, 1959. O filme, realizado a partir da peça de teatro homônima de Vinícius de Morais, recebeu diversas críticas do público brasileiro por sua inautenticidade: a população negra na favela é apresentada num ambiente em que quase todos os problemas sociais que a afligem estão ausentes. $\mathrm{O}$ filme conta com a trilha sonora de Tom Jobim e Vinícius de Morais, mas os espaços urbanos da nova classe média carioca (onde surgiu e era praticada a música usada no filme) está completamente ausente. Críticas mais severas surgiram pela exploração dos artistas locais pelo diretor europeu: muitos dos figurantes negros que atuaram no filme não receberam qualquer pagamento pelo trabalho, assim como o contrato feito com os músicos era para eles amplamente desvantajoso. Desse modo, apesar de o filme ter projetado uma imagem poética das populações negra nas favelas, elevando o samba e o carnaval à dimensão mítica (a peça de Vinícuis de morais é uma adaptação do mito grego de Orfeu ao contexto das favelas cariocas, mito que tematiza justamente os poderes encantatórios da música), ele não está isento das críticas de exploração cultural/econômica no eixo norte-sul, assim como de inautenticidade. O samba "Chiclete com Banana" de Jackson do Pandeiro resume muita das questões levantadas acima ${ }^{97}$. A possibilidade de misturar chiclete com banana, bebop e samba não é recusada pelo sambista, desde que haja reciprocidade nesse processo de internacionalização cultural.

97 Trecho da letra da canção: "Eu só boto bebop no meu samba/Quando Tio Sam tocar um tamborim/Quando ele pegar/No pandeiro e no zabumba/Quando ele aprender/Que o samba não é rumba/Aí eu vou misturar/Miami com Copacabana/Chiclete eu misturo com banana/E o meu samba vai ficar assim (...)" 


\section{Conclusão}

Vimos neste capítulo como, com a nova configuração política que entrou em cena com o Estado Novo, era necessário vencer as forças regionais que compunham a primeira república também no âmbito simbólico. Nesse contexto, a canção popular, com o samba à frente, emergiu enquanto símbolo por excelência da brasilidade, fortalecida até mesmo pelo fato de a maioria da população ser analfabeta, estar excluída da cultura letrada. A canção permeia espaços e classes sociais, numa "quebra de barreiras que é dos fatos mais importantes de nossa cultura" segundo Antônio Candido. Mas, enquanto símbolo da miscigenação étnica, cultural e da permeabilidade entre classes, ela também carrega as contradições a ambiguidades do popular: a fonte de autenticidade e cimento da coesão social, mas também o outro perigoso, violento, inculto. Música popular seria ora a expressão inculta e incivilizada das massas ignorantes, ora o lócus privilegiado para uma educação cívica e estética do popular, e sempre o "autenticamente" popular e brasileiro. Esta foi não apenas uma discussão da intelligentsia, mas registrada nos próprios sambas, questão vivida na prática do cancionista.

Nas décadas posteriores, culminando nos festivais do final da década de 1960, a canção fez apenas ampliar o seu protagonismo cultural no Brasil, assim como as ambiguidades e disputas das quais ela foi objeto também só se fizeram intensificar, conforme discutiremos nos próximos capítulos.

Note-se ainda como último registro da ascensão da canção e do samba como símbolo de brasilidade, o importante filme de Nelson Pereira dos Santos, Rio 40 graus, de 1955. Obra considerada precursora do cinema novo e do paradigma do nacional popular no cinema brasileiro, o filme é fruto da observação do diretor a respeito da vida das populações dos morros cariocas. Nelson Pereira dos Santos era então membro do Partido Comunista Brasileiro, sendo um dos precursores da temática social no cinema, sobretudo das favelas: "só não coloquei, no filme, comunista entrando, vendendo jornal, ninguém comprando" (Pereira apud Ridenti, 2014, p. 50). Tendo a vida nas favelas como foco da narrativa, o diretor procura fazer um retrato abrangente da capital carioca num domingo de sol. Não faltam os retratos do futebol, da vida social nas praias, das negociatas políticas, os turistas, a menina pobre do Nordeste que engravida de um soldado, os garotos da favela vendendo amendoim e pedindo esmola. A trama principal se dá em torno do noivado da jovem do morro Rosa. Ela é a paixão do violento Miro, que é ao mesmo tempo uma espécie de herói do morro: defendeu os trabalhadores na última greve havida, batendo nos policiais. Na cena final, Miro e o noivo de Rosa, Pedro, se encontram no samba, e para espanto geral, em vez de brigar, os dois se abraçam, pois são amigos e companheiros de luta nas greves. Essa 
última cena mostra a população pobre transmutada pelo samba: mulheres e homens trabalhadores estão agora vestidos de branco, de terno e vestido, dançam com graça e elegância. Em estilo pomposo de estadista, um locutor saúda a visita dos amigos da Portela, reforçando a transformação do povo em realeza durante o samba: o drama popular é sublimado num samba feliz. Em tomada aérea cobrindo a cidade, é tocado o samba de Zé Keti, no qual o próprio samba é transformado em personagem, ele é a voz do morro, a alegria do brasileiro:

A voz do morro, Zé Keti, 1955

Eu sou o samba

A voz do morro sou eu mesmo sim senhor

Quero mostrar ao mundo que tenho valor

Eu sou o rei dos terreiros

Eu sou o samba

Sou natural daqui do Rio de Janeiro

Sou eu quem levo a alegria

Para milhões de corações brasileiros

Mais um samba, queremos samba

Quem está pedindo é a voz do povo de um país

Pelo samba, vamos cantando

Essa melodia de um Brasil feliz 


\section{Capítulo VI: Bossa Nova}

\section{Nacionalização e internacionalização da bossa nova}

Se nas décadas de 20 e 30 do século XX a canção popular e, sobretudo, o samba alcançaram o status de símbolo de brasilidade por excelência, manifestação cultural em torno da qual diversos grupos étnicos e classes sociais encontraram um referencial comum quanto a ser brasileiro, foi somente a partir da bossa nova que a canção popular brasileira adquiriu projeção nacional e internacional como forma cultural digna de apreciação "séria"98. músicos eruditos, jazzistas, diretores de cinema, críticos literários e demais produtores culturais identificados com a alta cultura passaram a considerar a canção como forma artística digna de atenção. Não mais como os compositores eruditos do começo do século, que viam no popular uma fonte de inspiração legitimamente nacional, mas que deveria ser elevada pela verdadeira arte (WISNIK, 1982), mas sim como uma forma artística já em si mesma rica e estimulante.

Tornou-se lugar comum nos estudos da música popular brasileira dizer que a bossa nova inaugurou um arco no qual, indo até a tropicália, a canção popular se modernizou, adquiriu um novo status cultural, consolidando a prestigiosa instituição cultural chamada $\mathrm{MPB}^{99}$. Ou seja, se, nas décadas anteriores, a canção tornou-se popular - com ampla penetração social, utilizada até mesmo pelo aparato do Estado Novo como expressão de brasilidade - com a bossa nova, ela assumiu relevância cultural para além do popular. Assumindo o samba enquanto paradigma da brasilidade, ela introduziu novos elementos formais que se tornariam o filtro a partir do qual a tradição cancional seria relida ${ }^{100}$, e a partir da qual se produziriam canções com pretensões culturais elevadas. Isso com tamanha força que chegaria a oprimir outras formas da canção: o samba tradicional passou a ser tachado de "sambão quadrado", a canção passional de "brega" e assim por diante. Foi tão forte o crivo de avaliação instaurado a partir da bossa nova que, daí em diante, se tornariam corrente as noções de "modernização", “evolução", "passo à frente" no intenso debate cultural dos anos 60 e 70 (e também nos anos 80 com a vanguarda paulista). Retomar formas cancionais

\footnotetext{
${ }^{98}$ Poder-se-ia argumentar que compositores como Chiquinha Gonzaga e Villa-Lobos realizaram muito antes da bossa nova uma aproximação da linguagem popular e erudita na música brasileira. Mas nesses casos, a canção não era a forma trabalhada.

${ }^{99}$ A esse respeito, veja-se: Julio Medaglia. Balanço da bossa nova. Augusto de Campos (org.). Balanço da bossa e outras bossas. 5a ed. São Paulo: Perspectiva, 1993. Marcos Napolitano. Seguindo a canção: engajamento político e indústria cultural na MPB (1959-1969). São Paulo: Annablume/FAPESP, 2001. 100" A bossa nova atuou como filtro, através do qual elementos da música popular anteriores a ela foram assimilados posteriormente na música popular. Não só Ary Barroso e Dorival Caymi, mas muitos estilos do passado serão re assimilados pelas lentes da bossa. Por exemplo, o modo como Chico se apropriou de Noel." Marcos Napolitano. Seguindo a canção: engajamento político e indústria cultural na MPB (1959-1969). São Paulo: Annablume/FAPESP, 2001. p. 27
} 
anteriores à bossa nova era sinônimo de passo a trás, involuir ${ }^{101}$. Tamanho o prestígio cultural da bossa que Tom Jobim se transformou em monumento cultural brasileiro (POLETTO, 2010): universidades, aeroportos e salas de concerto receberam o seu nome, bem como uma estátua em sua homenagem foi erguida no Arpoador, praia do Rio de Janeiro.

Uma vez que o nosso foco está nas representações da modernidade brasileira, é preciso apreender, em primeiro lugar, as múltiplas camadas de sentido em que a bossa nova se associou às noções de modernidade e desenvolvimento, tanto da linguagem cancional quanto nacional. Como primeiro passo, a famosa declaração de Jobim por ocasião do concerto no Carnegie Hall, em 1962, o qual sedimentou a bossa nova como fenômeno internacional, nos dá muitos elementos:

\footnotetext{
Já não vamos tentar 'vender' o aspecto exótico, do café e do carnaval. Já não vamos recorrer aos temas típicos do subdesenvolvimento. Vamos passar da fase da 'agricultura' para a fase da 'indústria'. Vamos apresentar a nossa música popular com a convicção de que ela não só tem características próprias, como alto nível técnico. E acho que conseguiremos nos fazer ouvir e respeitar. (JOBIM apud POLETTO, 2010, p. 27).
}

A analogia entre a nova forma cancional e a superação do subdesenvolvimento econômico, a passagem de uma estrutura produtiva simples para outra mais complexa, desenvolvida e moderna, de "alto nível técnico", mostra-nos até que ponto a bossa nova estava afinada com o pensamento socioeconômico prevalecente nos anos de Juscelino Kubitschek. Seguindo a síntese desse período feita por Schwarcz e Sterling (2015), temos que no período de Kubitschek na presidência se consolidou, a partir de Celso Furtado e de intelectuais ligados ao ISEB (ORTIZ, 1985; SCHWARCZ; STERLING, 2015), um pensamento segundo o qual o subdesenvolvimento era uma condição de sociedades, como a brasileira, cuja inserção no capitalismo internacional se dera como subsidiária do sistema colonial. A consequência disso seriam males crônicos que persistem apesar da modernização internacional: estrutura agrária arcaica, monocultura exportadora e desigualdade. Caberia então ao Estado promover um conjunto de reformas para que o país se modernizasse, se desenvolvesse, passasse da "fase da agricultura para a indústria":

A chave para construir esse novo país chamava-se "desenvolvimentismo" e defendia a ideia de que nossa sociedade, defasada e dependente dos países mais avançados, repartia-se em duas: uma parte do Brasil ainda era atrasada e

\footnotetext{
${ }^{101}$ Veja-se o ensaio de Augusto de Campos Da jovem guarda a João Gilberto, em: CAMPOS, 1993, op. cit.
} 
tradicional; a outra já seria moderna, e estava em franco desenvolvimento. Ambas, o centro e a periferia, conviveriam no mesmo país, e essa era uma dualidade que se devia resolver pela industrialização e pela urbanização. (SCHWARCZ; STERLING, 2015)

Uma das consequências diretas do projeto "50 anos em 5", ainda segundo as historiadoras, foi o acesso de uma parte da população a toda uma série de bens de consumo duráveis que vieram configurar um novo estilo de vida, de aspirações sofisticadas e modernas: televisão, máquina de lavar roupa, rádio de pilha... E, por que não admitir, as próprias canções bossanovistas eram também um bem cultural, produto e produtor desse novo estilo de vida que se desenhava na zona sul carioca. Produto e produtor, pois a bossa nova não apenas "representava" esse novo estilo de vida que surgia das aspirações de modernidade de uma classe social, como também ajudava ativamente a delinear a estética desse estilo de vida: estética aqui na acepção original de fenômeno sensível, sensório, novos modos de sentir corporalmente. Produto e produtor também no fato dos produtores da bossa nova pertencerem a esse grupo: ela marca a entrada de um novo estrato social no espaço de produção da música popular. Como formulou Lorenzo Mammì:

\footnotetext{
Surge a bossa nova e morre o botequim como lugar de criação da música popular. Aquela indistinção aparente, complementar à falta efetiva de mobilidade social, que aproximava Mário Reis e Sinhô, se esvanece. A nova música deve muito pouco ao samba do morro, muito mais, eventualmente, às lojas de discos importados que distribuíam Stan Kenton e Frank Sinatra. Sua postura em relação às influências internacionais é mais livre e solta, porque suas raízes sociais são mais claras e sua posição mais definida. Bossa nova é classe média, carioca. Ela sugere a idéia de uma vida sofisticada sem ser aristocrática, de um conforto que não se identifica com o poder. Nisto está sua novidade e sua força. (MAMMì, 1992, p.63)
}

Não por acaso, o título do artigo (“João Gilberto e o projeto utópico da bossa nova") refere-se ao "projeto utópico" da bossa nova, utopia de uma classe média que reclama uma condição cultural mais rica do que aquela que até então lhe fora reservada, e que procura eternizar um "momento feliz" da história brasileira, momento de utopias de um Brasil moderno.

Mas como pôde uma manifestação cultural de um nicho social tão específico firmarse no âmbito nacional e internacional como símbolo de brasilidade modernizada? Contam 
os cronistas e historiadores da bossa ${ }^{102}$ que ela surgiu na áurea idílica de pequenos apartamentos da zona sul carioca e na vida boêmia desse mesmo bairro (o famoso Beco das Garrafas). Seu marco inaugural é o LP "Chega de Saudade”, 1959, de João Gilerto. O minimalismo no arranjo e no canto recebeu o epíteto de "performance de apartamento", o que remete ao intimismo sugerido pela performance, mas também aos espaços onde ela surgiu: "Entre uma boate e um apartamento, ambos em Copacabana, no fim dos anos 50 João Gilberto modifica a canção brasileira" (GARCIA, 1999, p. 18). Que de um espaço tão diminuto possa ter saído tamanha influência, se explica em parte pelo fato de nele estar um círculo de músicos já influentes na música brasileira: Tom Jobim, Vinícius de Morais, Nara Leão, Ronaldo Bôscoli entre outros.

A partir da consolidação de um "estilo" bossa nova com características formais definidas no álbum de João Gilberto (lançado pela gravadora Odeon), teve início o processo de "nacionalização" da bossa, sua penetração no território nacional, primeiramente a partir de pequenos shows em diretórios acadêmicos: em 22 de setembro de 1959 realizou-se na faculdade de arquitetura do Rio de Janeiro o $1^{\circ}$ Festival de Samba Session (NAPOLITANO, 2001, p. 61). André Midani, importante produtor da Philips, estava na plateia e já a partir desse momento, Odeon e Philips, duas das mais importantes gravadoras, começaram a firmar contratos com a nova geração de músicos (como Carlos Lyra e Sérgio Ricardo), fazendo da música popular "moderna" um importante nicho de mercado. Posteriormente, nos anos de 1964 e 1965 foi realizada no teatro Paramount de São Paulo uma série de shows (Idem), organizados pelo radialista Walter Silva, que firmaram ainda mais o laço na nova música popular brasileira com o público universitário. Mas então já havia uma diferença fundamental: a bossa nova, enquanto sinônimo de popular "elevado" e consumida por um público com capital cultural relativamente elevado (estudantes universitários), conquistava também o status de oposição ao regime que se instalara em abril de 1964. Ou seja, ela, e sobretudo a corrente participativa da bossa nova que surgira no começo dos anos $1960 \mathrm{em}$ torno do Centro Popular de cultura da Une, passou a exercer o papel de cultura jovem de oposição. Nesse contexto despontaram nomes que formariam o panteão (ou na linguagem das gravadoras, o Cast) da MPB: Chico Buarque, Elis Regina, Toquinho, Gilberto Gil etc. Os Lps que decorreram desses shows tornaram-se best-sellers, ao passo que a expansão do público da bossa e da canção popular entrou em exponencial: do programa "Fino da Bossa", que se tornaria líder de audiência na TV Record, aos festivais da canção, quando foi atingido o paroxismo da relevância da canção na vida política nacional: a disputa entre "Sabiá" de

\footnotetext{
102 Ruy Castro. Chega de Saudade. São Paulo: Companhia das Letras, 1990.
} 
Jobim e Buarque e "Pra não dizer que não falei das flores" de Vandré tomou proporções consideráveis (POLETTO, 2010).

Paralelamente, ocorria também o processo de internacionalização da bossa nova, cujo divisor de águas foi o já citado show no Carnegie Hall em novembro de 1962, seguido por outras apresentações que familiarizaram os músicos americanos com a bossa. Segundo Medaglia (Op. Cit.), a penetração no mercado americano foi fundamental para que canções como "Desafinado" e "Garota de Ipanema" se tornassem fenômenos mundiais, num processo de internacionalização semelhante ao que antes havia ocorrido com Carmen Miranda. Entretanto, a grande diferença foi que, dessa vez, não apenas penetrou como também modificou o mercado americano. Nas palavras de Augusto de Campos, ela foi de influenciada a influenciadora do jazz: "Sim, a bossa nova foi uma revolução na música popular, e não apenas na brasileira. Segundo a revista Down Beat, há 40 anos ninguém influenciava a música americana como o fez João Gilberto" (CAMPOS, 1993, p.180). Tal influência mostrou-se nas elevadas posições assumidas nas paradas de sucesso, pelos vários álbuns gravados com temática bossa nova e pelos músicos consagrados como Stan Getz, Charlie Byrd e Frank Sinatra que se aproximaram dos brasileiros. Tom Jobim e João Gilberto transferiram residência para os EUA (na verdade, toda uma trupe surfou na onda bossa nova nos EUA: João Donato, Sérgio Mendes, Moacir Santos entre outros), marcando um relativo distanciamento deles em relação aos desdobramentos da canção no Brasil, a qual se politizava cada vez mais. Jobim gravou, em 1963, “The Composer of Desafinado Plays”, em 1965, “The Wonderful World of Antonio Carlos Jobim” e, em 1967, “A certain Mr. Jobim”, álbuns que consolidaram sua presença no mercado americano de tal modo que várias de suas canções tornaram-se standards de jazz, publicadas no livro cânone Real Book. Nesse momento da carreira de Jobim firmou-se a estética "clássica" da bossa nova, em contraposição à vertente engajada que se desenvolvia.

A partir do processo de internacionalização, a bossa alcança aquilo que Jobim almejava quando da sua declaração citada acima: ela tornou-se um produto cultural de "alto nível técnico", ouvida mundialmente e respeitada, realizando no plano simbólico da canção popular a aspiração de superar o subdesenvolvimento e colocar o Brasil entre os países exportadores de cultura. Novamente nas palavras de Augusto de Campos: "a bossa deu a virada sensacional na música brasileira [...] conseguindo que o Brasil passasse a exportar para o mundo produtos acabados e não mais matéria-prima musical (ritmos exóticos), 'macumba para turista', segundo a expressão de Oswald de Andrade" (CAMPOS, 1993, p. 286). 
Este é um dos aspectos nos quais a bossa nova construiu uma representação da modernidade brasileira "livre, generosa e socializável"103: canção sofisticada, de amplo sucesso popular mundial. Ainda assim, também nos aspectos técnicos, os quais veremos a seguir, ela formalizou processos sociais e aspirações de modernidade.

\section{A canção bossa nova}

O primeiro LP da bossa nova a criar um marco na história da canção popular foi Chega de Saudade, de João Gilberto, em 1959. João Gilberto foi sobretudo um intérprete (neste seu primeiro LP apenas duas canções são de sua autoria: Bim Bom e Ho-Ba-La-La), que promoveu uma releitura do samba, dispensou a intensidade passional na emissão da voz e valorizou os aspectos harmônico-percussivos do violão, evocando o ritmo do samba pelo seu viés mais irregular, as batidas do tamborim (TATIT, 2004, p.49). Assim sumariza Tatit algumas características da interpretação de João Gilberto:

\footnotetext{
Neutralizou a potência de voz até então exibida pelos intérpretes, já que sua estética dispensava a intensidade e tudo que pudesse significar exorbitância das paixões. Neutralizou o efeito de batucada que, por trás da harmonia, configurava o gênero samba em boa parte das canções dos anos trinta e quarenta, eliminando a marcação do tempo forte na batida do violão. Desfez a relação direta entre o ritmo instrumental e a dança que caracterizava as rodas de samba. Dissolveu a influência do cool jazz nos acordes percussivos estritamente programados para o acompanhamento da canção, sem dar espaço à improvisação. E, acima de tudo, pela requintada elaboração sonora do resultado final, desmantelou a ideia dominante de que "música artística" só existe no campo erudito. (TATIT, 2004, p. 50)
}

A releitura da bossa nova, como descreve Tatit, baseia-se sobretudo numa série de neutralizações, de reduções de elementos expressivos da canção ao seu formato mínimo, em contraste com o samba da década de 1950, comumente executado em formações orquestrais e performances virtuosísticas (pense-se nas performances de Carmen Miranda ou na intensidade passional dos sambas de Lupicínio Rodrigues). É por esse motivo que, novamente Luiz Tatit, identifica na bossa nova um gesto de triagem que a partir de então comporia um dos núcleos fundamentais da canção brasileira. O processo de triagem

\footnotetext{
${ }^{103}$ Guilherme Wisnik. Cerimônia mostrou um Brasil que ainda pulsa e se atualiza diante de nós. Folha de São Paulo. São Paulo, 08 agosto 2016. Disponível em: http://www1.folha.uol.com.br/colunas/guilherme-wisnik/2016/08/1800104-cerimonia-mostrouum-brasil-que-ainda-pulsa-e-se-atualiza-diante-de-nos.shtml. Acesso em: 03/01/2017.
} 
caracteriza-se pela “operação simultânea de eliminação e seleção de valores, considerados respectivamente como indesejáveis e desejáveis, de acordo com a visão de mundo de um grupo social num período histórico determinado" (TATIT, 2004, p.93). A bossa nova eliminou, na temática das letras das canções, os conteúdos excessivamente passionais, os quais pediam do intérprete uma grande intensidade e extensão na emissão da voz para dar veracidade à "dor" exprimida nas letras, dando preferência a temas que retratassem o próprio samba ou a alusões rarefeitas aos conteúdos passionais, como o "amor, o sorriso e a flor".

Desse modo, Tatit interpreta a bossa nova como um gesto que permaneceria ativo na linguagem cancional brasileira: a triagem, o ato de selecionar, despojar a canção de atributos que não sejam essenciais. Mas é necessário lembrar que a triagem da bossa nova foi feita mediante a releitura, o que vai de acordo com a análise de Brasil Rocha Brito ${ }^{104}$ (num dos primeiros ensaios dedicados à análise formal da bossa nova), de que ela foi uma revitalização do popular. Mediante a pesquisa do material popular, compositores e intérpretes bossanovistas extraíram procedimentos estruturais, integrando-a canção brasileira nos parâmetros modernos de composição ${ }^{105}$. Ou seja, pela releitura, faz-se a triagem de características que são transformadas em procedimentos estruturais.

Dentre esses procedimentos, Rocha Brito destaca o não reconhecimento da hegemonia de um parâmetro sobre os demais: melodia, harmonia e ritmo, todos se integram na proposta estética da canção, sem destaque particular. Mesmo o intérprete coloca sua voz sem se sobrepor em relação aos outros elementos: daí que a canção passe a ser vista menos como performance vocal (e que o público a identifique menos com o intérprete) e mais como uma obra que conjuga diversos elementos, trazendo o compositor para o primeiro plano. Várias vezes já foi repetido que, com a bossa nova, compositores e intérpretes "sem voz" sentiram-se encorajados a assumir o papel de intérprete (por exemplo, o próprio João Gilberto, ou mesmo Vinícius de Morais). Outro parâmetro é o chamado caráter anticontrastante das canções: em vez do dualismo harmônico típico de tensão e relaxamento, dissonância e consonância, a canção bossanovista trabalha com progressões de acordes alterados. Na linguagem de Tatit, esse procedimento é chamado de "acordes de engate e desengate": na harmonia tradicional há um caminho "natural" da tônica pelos graus da escala

\footnotetext{
104 Brasil Rocha Britto. Bossa Nova. Em: Augusto de Campos (org.). Balanço da bossa e outras bossas. 5a ed. São Paulo: Perspectiva, 1993.

$105 \mathrm{O}$ autor escreve que ela "tira o atraso" da música popular brasileira em relação à erudita, o que se, por um lado, conflui com ideias exploradas por Augusto de Campos sobre as conexões e procedimentos comum entre o popular e o erudito, adianta também aspectos da ideia de "linha evolutiva" da canção popular (elaborada por Caetano Veloso apenas alguns anos mais tarde) justamente no que ela tem de mais problemático: de que haveria um sentido unívoco na evolução da linguagem musical.
} 
e de volta para a tônica, no qual o acorde dominante (V grau da escala, auge da dissonância) é o "engate" para o retorno à tônica. Mas a introdução de acordes alterados abre maneiras de "desengatar" esse caminho e abrir outros, menos previsíveis. Daí que a melodia e a linha de canto também saiam de sua rota previsível, harmonia e melodia interceptam-se e comentam-se mutuamente. Diferentemente do jazz, o qual é sem dúvida a fonte de inspiração dos acordes alterados e das modulações de tom - a bossa valoriza a melodia, nela não há improviso instrumental virtuosístico assim como a melodia não adquire vida independente da harmonia ${ }^{106}$ (e quando jazzistas americanos usam essas canções como standards para a improvisação, a sensação é de completa futilidade dos arabescos melódicos ${ }^{107}$. Ou seja, na bossa nova, a melodia perde seu rumo previsível, sua autonomia habitual, mas ainda assim é valorizada: caminhos imprevisíveis que, porém, soam como necessários. O "samba de uma nota só" é o caso paradigmático de interação entre melodia e harmonia onde cada uma adquire seu sentido em relação a outra, e onde a letra recorta a melodia comentando essa relação e transformando-a em analogia da relação amorosa. Um exemplo de integração de parâmetros, onde cada um é resumido ao mínimo para render o máximo.

O acorde compacto com notas alteradas concilia as funções harmônica e rítmica, uma totalidade compacta apropriada à batida executada pelo violão: a dissonância, ao mesmo tempo que abre os caminhos melódicos se encontra com a periodicidade temática, a reiteração de motivos rítmicos extraídos do samba. Chegamos aqui ao fator que conferiu à bossa nova sua característica estilística definida: a batida de violão. Foi a batida criada por João Gilberto que promoveu o "salto" da bossa, que catalisou os esforços anteriores de transformação do samba em um estilo facilmente reconhecível: ouça-se a esse propósito o álbum "Canção do amor demais" de Elisete Cardoso e compare-se com "Chega de Saudade", gravado poucos meses depois (GARCIA, 1999, p. 74). A batida de violão formalizou a transformação estética que vinha sendo feita por Jobim e Vinícius de Morais.

O estudo de Walter Garcia (1999), que disseca e interpreta esse fator estilístico central da bossa, identifica no violão de João Gilberto a redução da batucada ao violão, estilizando jazzisticamente as sincopas do tamborim. Em se tratando do violão, onde uma mão se encarrega de gerar a parte rítmica, temos apenas dois elementos estruturais a compor a batida: o bordão (as notas graves geradas nas três cordas superiores) executado pelo polegar, e o ataque dos acordes realizados pelos dedos médio, anular e indicador. O bordão

\footnotetext{
${ }^{106}$ Na observação de Rocha Brito: mesmo que se assobie uma melodia bossa nova, ele é de tal modo dependente da harmonia que sempre teremos os acordes na cabeça.

${ }^{107}$ Ouça-se a versão de "Retrato em branco e preto", por Chet Baker.
} 
de João Gilberto acentua de maneira uniforme os dois tempos fortes do compasso binário, ao contrário do surdo do samba (o elemento percussivo de som mais grave), o qual marca apenas o segundo tempo do compasso. A defasagem causada pela marcação do segundo tempo é a responsável pela força com que a batucada convida o corpo à dança, a sua qualidade "temática", no vocabulário de Tatit. Que a batida da bossa opte pela uniformidade do bordão, significa que ela "renuncia ao convite à dança", não exerce o mesmo apelo físico, mas induz o ouvinte a uma apreciação estético-contemplativa. Nesse quesito, ela recupera o samba canção tradicional (o Orlando Silva tão admirado por João Gilberto). Esse é o "samba de meio de ano", com tendências mais passionais do que o samba para o carnaval. Já o ataque dos acordes evoca o ritmo do piano jazzificado e do tamborim da batucada, o elemento que se destaca pelo timbre agudo e por sua liberdade rítmica. É nesse aspecto que a batida mais se aproxima do jazz ainda que, diferentemente dele, ela mantenha a mesma figura rítmica por toda a canção (ainda que sincopada).

Desse modo, a batida se constrói pela articulação da regularidade do baixo com a irregularidade dos ataques dos acordes. O primeiro elemento institui a baliza, a regra, enquanto o outro a desrespeita. A regularidade e a irregularidade constroem-se mutuamente, naquilo que Garcia chama de "contradição sem conflito", equilíbrio entre o samba e o jazz, o local e o universal, num jogo de identidade e diferença: "uma forma estética que suspende, a um novo patamar, a antiga contradição entre o arcaico e o moderno, o local e o exterior, o particular e o universal, este é um daqueles verdadeiros milagres que ocorrem na experiência brasileira apenas algumas poucas vezes" (GARCIA, 1999, p.114).

Milagre ou não, a bossa nova alcançou formalizar aspirações de um momento da cultura brasileira: aspiração de integrar-se ao moderno, ao desenvolvimento, ao internacional, sem renunciar ao local, articular sem conflitos os diversos elementos num movimento de transformação.

\section{Melodia e letra}

Vimos acima algumas das formas nas quais a bossa nova interpelou a ideia de um Brasil moderno, pelo desejo de criar uma música popular sofisticada e ultrapassar a "fase da agricultura" musical com o desenvolvimento de técnicas composicionais sofisticadas. Estas, articulam o influxo estrangeiro com o nacional, o popular e o erudito, o tradicional e o moderno, a lei e a transgressão numa contradição sem conflitos. Podemos deter-nos ainda mais um instante nos aspectos musicais antes de avançarmos para as letras. Relembrando a classificação de Middleton das conotações que podem emergir de eventos musicais, os 
valores intencionais ocorrem quando eventos sonoros são intencionalmente criados para adquirir determinada conotação (como o uso de um berimbau para conotar local ou tradicional). Os parâmetros musicais da bossa nova vistos acima possuem, nesse sentido, valores intencionais, buscavam propositalmente evocar a noção de uma modernidade brasileira, o samba "novo", não mais subdesenvolvido. Ou seja, a canção bossa nova evoca conotações de modernidade mesmo quando a letra não o articula explicitamente.

Lembrando também do argumento de Tatit (2016), a respeito da oralização e da musicalização, sendo que a primeira entoação se aproxima da fala e a letra adquire maior peso semântico (como no caso do rap); e na segunda ela perde seu peso semântico ao se aproximar do som puramente musical, a canção bossanovista é para Tatit o grande exemplo de musicalização: as letras perdem muito do seu valor semântico e ganham na valorização do seu aspecto musical. Essa percepção é partilhada por Medaglia, para quem, na bossa nova, os textos não são valorizados, mas sim a palavra como unidade sonora ( $O p$. Cit.). Porém, essas observações não devem fazer crer que o elemento textual na bossa é desimportante. Pelo contrário, musicalização e dessemantização são estratégias desse tipo de canção, um recurso da ilusão enunciativa para dar persuasão à atmosfera de leveza muitas vezes elaborada pelo texto. Muitas das canções constroem cenas do cotidiano urbano e praieiro, crônicas de uma vida que saboreia as sutilezas ${ }^{108}$. O tipo de conjunção entre sujeito e objeto proposta pela bossa depende da leveza proporcionada pela musicalização, do difícil e muito breve equilíbrio conquistado pela letra, harmonia, melodia e ritmo. A canção "Felicidade" de Jobim e Vinícius de Morais pode ser ouvida como um manifesto da "promessa de felicidade"109 feita pelas canções bossanovistas: "A felicidade é como a gota / De orvalho numa pétala de flor / Brilha tranquila / Depois de leve oscila / E cai como uma lágrima de amor", "A felicidade é como a pluma / Que o vento vai levando pelo ar / Voa tão leve / Mas tem a vida breve / Precisa que haja vento sem parar". O "momento feliz" da bossa nova advém dessa leveza, desse tênue equilíbrio, da contradição sem conflitos, do encontro de uma linha entoativa melodiosa com uma sequência de acordes alterados, por vezes sem um centro tonal definido.

\footnotetext{
108 Por exemplo: "Lobo bobo", "Brigas nunca mais", "Saudades fez um samba em seu lugar", todas do Lp Chega de Saudade.

${ }^{109}$ Promessa de felicidade é expressão célebre criada por Henri Beyle, ou Stendhal, escritor francês do século XVIII. No seu tratado sobre o amor De L'amour (1822), ele expôs a famosa analogia do galho seco lançado às minas de sal de Salzburg. Quando se lança um galho nas minas, em poucos dias todo o seu corpo, mesmo as mais míseras hastes são recobertas de brilhantes cristais de sal. Assim seria a mente de uma pessoa apaixonada: ela recobre a imagem do ser amado, mesmo seus defeitos, com inúmeros brilhantes cristais do seu desejo, da felicidade que ele pretende alcançar com a pessoa amada. Assim a beleza da pessoa amada corresponde à expectativa de felicidade que ela promete: a beleza é a promessa de felicidade.
} 
"Garota de Ipanema", "Chega de Saudade", "Samba de uma nota só", "Desafinado" são canções que não apenas firmaram esse estilo no contexto musical global, mas são também manifestos dessa promessa de felicidade, conquistada em transitório e improvável equilíbrio. Na primeira, a persona construída pela letra transmite seu prazer em observar o balanço feminino, balanço transportado à curva entoativa temática, contrabalançado na parte B, passional, que fala de solidão e ausência do objeto de desejo, só para voltar com alegria renovada à contemplação do balanço. Se há nessa canção certa melancolia, o índice eufórico é certamente predominante. Estrutura semelhante a "Chega de Saudade", na qual a parte A, em ré menor, articula na letra a separação entre sujeito e objeto de desejo: saudade é a palavra própria para designar a presença virtual e dolorosa de um objeto de desejo ausente. A modulação harmônica transpõe a tonalidade para ré maior, onde a alegria antecipada do reencontro é tematizada pela letra e pela curva da entoação. "Samba de uma nota só" e "Desafinado" são canções cujas letras articulam ao mesmo tempo um comentário a respeito da própria canção, mas que funciona também como recado amoroso: o despojamento e aparente simplicidade (da melodia sustentada por uma sequência harmônica complexa) saudadas na primeira são equiparadas à alegria conjugal. Na segunda, o enunciador defendese das acusações de desafinar, aludindo à naturalidade da música e à grandeza do amor.

Nessas canções-símbolo da bossa predominam a conjunção, a euforia, embora a passionalização e as demais tendências da canção também sejam acionadas (segundo o argumento de Tatit de que as quatro tendências estão sempre presentes). No entanto, Júlio Medaglia, em artigo de 1966, elabora uma interessante chave de leitura "a contrapelo" da bossa. O "elogio da leveza", as crônicas do cotidiano suave, citadino, praieiro e romântico, a promessa de felicidade de uma modernidade que suavizaria os contrastes ( em vez de intensificá-los), essa "sede de afetividade, pureza e ingenuidade" (CAMPOS, 1993, p. 87) não são a simples expressão de um momento feliz (para um determinado estrato social), eles não registram um dado, mas sim uma aspiração afetiva. É um contraponto ao que se estaria perdendo, rareando com o avanço da industrialização: "Como que tentando uma reação, a fim de não sucumbir ao determinismo da técnica, à aridez do asfalto, à luta aflitiva pela sobrevivência material [...] a imaginação poética $\mathrm{BN}$ foi encontrar na simbologia do 'amor sorriso e flor' a sua fonte de inspiração e energia espiritual" (Idem).

Nessa chave de leitura, a leveza da bossa nova não é um mero reflexo, mas um antirreflexo do processo de modernização, um registro do que estava sendo varrido. Essa é uma hipótese que seria difícil de sustentar no final dos anos 1950, mas o passar dos anos 
veio a dar cada vez mais sentido a essa leitura, como se depreende dos seguintes depoimentos de Jobim:

Veja: Para você, escrever uma letra hoje é mais fácil do que nos tempos de "Garota de Ipanema?Tom: Não sei se a gente pode falar de fácil. Era diferente. Naquele tempo, fumaça era progresso, não era veneno. Só por isso você já pode ver até que ponto eram diferentes as coisas... (JOBIM apud POLETTO, 2010, p. 263)

Acho que estamos num grande dilema. O homem, na ânsia do progresso, está destruindo tudo: as árvores, os rios, os animais. Toda chaminé que surge, cada automóvel, tudo o que é baseado na combustão, vai eliminando o oxigênio do ar. E olhe que só temos oito quilômetros para cima; depois, tudo fica bastante rarefeito. Então, ao mesmo tempo em que o progresso resolve certos problemas, cria a cidade neurótica, a São Paulo, a Nova Iorque. O Rio de Janeiro tem o tráfego, o assalto, a metralhadora, o apartamento, o refrigerado. Aí eu faço uma música como Matitaperê (sic) e fica um negócio assim de a pessoa ter de ir ao dicionário procurar o significado. O matita é um passarinho do sertão: ele não vai nos ajudar a comprar nada, a ir ao supermercado, a comprar máquina de lavar roupa... assim ele começa a virar uma figura, como direi (underground?), uma figura folclórica, um ente, um saci. Ora, o que é que o barulho do Rio tem a ver com um saci? Saci não dá em apartamento. (Idem).

Já nos anos 70, em plena vigência da ditadura civil-militar e do AI-V, a canção de Vinícius de Morais e Toquinho retoma, na chave da nostalgia, o período de nascimento da bossa nova e seu espaço social: Ipanema, céu, Redentor, e como se turvou aquele Rio de amor.

\section{Carta ao Tom 74}

Rua Nascimento Silva,cento e sete

Você ensinando prá Elizete

As canções de canção do amor demais

Lembra que tempo feliz, ai que saudade,

Ipanema era só felicidade

Era como se o amor doesse em paz

Nossa famosa garota nem sabia

A que ponto a cidade turvaria este

Rio de amor que se perdeu

Mesmo a tristeza da gente era mais bela 


\title{
E além disso se via da janela \\ Um cantinho de céu e o Redentor \\ É, meu amigo, só resta uma certeza, \\ É preciso acabar com essa tristeza \\ É preciso inventar de novo o amor
}

Mesmo que a "famosa garota" ainda não soubesse que a pureza, afetividade e ingenuidade da bossa se tornariam nostalgia, o que de fato resultou da transformação do espaço urbano num período de modernização e industrialização não foi a superação dos contrastes sociais em direção a uma totalidade não contrastante como a estética da canção bossa nova. Mas, pelo contrário, a intensificação dos contrastes sociais até o limite do suportável e do coabitável, resultando na irreparável perda da leveza proposta por essa estética. Na sátira de Jobim e Buarque, de 1977:

\author{
Rua Nascimento Silva, 107 \\ Eu saio correndo do pivete \\ Tentando alcançar o elevador \\ Minha janela não passa de um quadrado \\ A gente só vê cimento armado \\ Onde antes se via o Redentor \\ É, meu amigo \\ Só resta uma certeza \\ É preciso acabar com a natureza \\ É melhor lotear o nosso amor
}

Sabiá é provavelmente a canção mais emblemática da passagem da bossa, da promessa de felicidade às ilusões da delicadeza perdida. Apresentada no terceiro Festival Internacional da Canção (FIC), da TV Globo, 1968 (POLETTO, 2010, p.82) - o mesmo ano da erupção da tropicália, também nos festivais - a canção foi marcada por uma polêmica significativa quanto ao fim da possibilidade da leveza bossanovista. Sabiá, primeira parceria entre Tom Jobim e Chico Buarque e Pra não dizer que não falei das flores de Geraldo Vandré enfrentaram-se na eliminatória carioca do festival, e a vitória da primeira foi recebida com "uma vaia retumbante, prolongada, maciça e raivosa" (Idem) do público. Este manifestava apoio à canção de Vandré, que se tornaria a mais emblemática canção de 
protesto da era dos festivais. A canção de Vandré era uma negação, praticamente ponto por ponto, da proposta bossanovista: sem sofisticação harmônica, da forma mais simples e direta possível ela comunicava um texto cujo peso semântico é o único que há de relevante. Ou seja, a canção funciona como suporte da comunicação política: pelos campos há fome, as flores vencem os canhões, a antiga lição de morrer pela pátria e viver sem razão deve ser substituída pela nova de tomar a história nas mãos e fazer acontecer. $\mathrm{O}$ chamado de urgência em resistir (não se deve esperar!) à opressão militar conquistou a simpatia do público majoritariamente estudantil do maracanãzinho (onde se fazia a eliminatória), ao passo que o júri deu a vitória a Sabiá. Jobim e Buarque, ambos já ícones da canção brasileira, foram então recebidos pela vaia.

Essa canção tinha realmente todas as qualidades para causar estranhamento no público e decepcionar quem aspirava por engajamento político. Ainda assim, ou por isso mesmo, ela é um extraordinário registro das desilusões do ideário bossa nova. A letra de Sabiá opera uma releitura da Canção do Exílio de Gonçalves Dias, subvertendo o saudosismo ufanista do poema:

\author{
Vou voltar \\ Sei que ainda vou voltar \\ Para o meu lugar \\ Foi lá e é ainda lá \\ Que eu hei de ouvir cantar \\ Uma sabiá \\ Vou voltar \\ Sei que ainda vou voltar \\ Vou deitar à sombra \\ De uma palmeira \\ Que já não há \\ Colher a flor \\ Que já não dá \\ E algum amor talvez possa espantar \\ As noites que eu não queira \\ E anunciar o dia
}

\title{
Vou voltar
}

Sei que ainda vou voltar

Não vai ser em vão

Que fiz tantos planos 


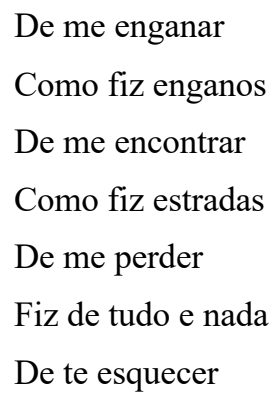

Como observou Mammi. a primeira estrofe de Buarque inverte a estrutura conceitual das últimas estrofes de Gonçalves Dias. Se, no poema, há a esperança de volta a uma terra pródiga em belezas naturais e alegria de viver (as aves, as estrelas, flores, vida, amores e palmeiras) a letra da canção repete obsessivamente "Vou Voltar", mas a palmeira já não há e a flor já não dá. Enquanto letra e melodia repetem "Vou voltar", a afirmação é contradita pela harmonia que, sem tonalidade definida, perde-se em modulações:

\footnotetext{
"Sei que ainda vou voltar", que poderia sugerir uma reiteração, é na realidade um esvaziamento: devido à marcha harmônica, o segundo 'voltar' está mais distante do que o primeiro, e 'o meu lugar' fica ainda além, num "lá e ainda lá" em fá sustenido, inalcançável como um horizonte, de onde vem não a voz, mas a promessa da voz de uma sabiá (MAMMI, 2004, p. 23, grifo nosso)
}

A segunda estrofe vem sublinhar tudo o que há de ilusório na esperança, na promessa de voltar: "planos de me enganar", "enganos de me encontrar", "estradas de me perder". Se no plano denotativo do texto está claro que se fala de ilusão, perda, esvaziamento, para quais eventos extratextuais ela poderia apontar no plano conotativo? Novamente Mammi: "A ilusão de uma modernização doce, segundo a qual uma industrialização acelerada poderia conviver com o clima edênico da beira-mar carioca, se desfaz completamente nessa canção" (Idem). Que a canção, em pleno 1968, quando a juventude engajada tinha os olhos e esperanças voltados para o "amanhã”, o "dia que virá", fale em voltar, em regresso impossível, já é muito significativo da desilusão ante um processo modernizador que prometia vencer a dualidade legada pelo subdesenvolvimento. Ao contrário, há o acirramento das tensões ante um regime autoritário: destruição da natureza, poluição, espaço urbano opressivo, miséria, marginalidade e ataque às liberdades civis. Diante do novo quadro social, tendências da canção popular partem para novas posições: o engajamento político (a canção de protesto) e o engajamento estético (tropicália). 


\section{Conclusão}

A bossa nova é sem dúvida um dos momentos mais importantes da canção brasileira, especialmente por ser o ponto de inflexão na dinâmica cultural da canção, a qual culmina na emergência da MPB enquanto marco cultural brasileiro e a relevância sem precedentes da canção na vida cultural e política brasileira no final dos anos 1960. Ela logrou isso ao articular, tanto na estética musical quanto no conteúdo doas letras, o desejo de desenvolvimento, modernização e industrialização dos anos 1950. Ela pretendeu mostrar o caminho, ainda que na diminuta esfera da prática cancional, para a superação dos aspectos "arcaicos" da sociedade brasileira (pobreza, segregação, desigualdade social, subdesenvolvimento econômico etc.) numa forma arrojada, cosmopolita, mas ainda assim inconfundivelmente brasileira. Um delicado equilíbrio conquistado pela contradição sem conflito: do popular com o erudito, do local com o internacional, do ritmo e sua quebra (a ordem e a desordem).

O argumento de Garcia (1999) a respeito da "contradição sem conflitos" nos remete à dialética da malandragem e da posição social do samba nas décadas de 1920 e 1930. Naqueles momento, ordem e desordem se interpelam e interpenetram, sobretudo na figura do malandro, ao passo que o samba, fruto do encontro de heranças culturais distintas, se torna símbolo de um pais alegremente mestiço. Já a dialética da bossa nova retoma a quebra de barreiras da malandragem e sua contradição entre ordem e desordem, mas a partir de um estrato social privilegiado: uma classe média urbana que flerta com a modernização do estilo de vida propiciada pela modernização [???]. O elemento subversivo na bossa nova não é a insinuação do corpo, da sensualidade, do erótico no ritmo e na dança, mas a ideia de uma modernização “à beira mar”. Ou, como vimos com Medaglia, aquela em que os elementos afetivos que estavam sendo varridos pelo asfalto eram resgatados e mantidos na equação do Brasil moderno. Se o samba logrou uma "quebra de barreiras que é dos fatos mais importantes da nossa cultura", a bossa nova também o fez, mas não tanto no sentido das barreiras entre estratos sociais, mas entre a afetividade e a modernização do estilo de vida, o gingado local e a inventividade formal cosmopolita.

Retomando ainda mais uma vez os argumentos de Garcia, temos que a regularidade do baixo na batida da bossa nova leva à renúncia do apelo à dança (1999, p. 27), o que afasta o samba da sua função social de dança coletiva e festa popular, sendo então dirigido para a apreciação contemplativa e intelectual. A renúncia ao ritmo marcado e à corporalidade da dança, tão presentes no samba, são significativos do protagonismo de uma outra classe social. Nesse sentido, a bossa nova é a plena realização da canção "Feitiço da Vila", de Noel Rosa: bacharéis que abraçam o samba e o expurgam dos elementos demasiadamente 
corporais e populares - feitiço decente - "branco na poesia" embora ainda reste algo de negro no coração. Essa linha de raciocínio levou nomes como José Ramos Tinhorão a julgála como engodo cultural, uma expropriação da música popular do seu nicho de origem, entregando-a aos interesses internacionais e imperialistas. $\mathrm{O}$ flerte da bossa nova com a cultura e o mercado norte americanos é inegável, bem como seu balanço e seu gingado trazem a marca iniludível de uma origem social privilegiada. Mas também é inegável que essa síntese cultural, ainda que feita a partir "de cima", procura apontar caminhos para um Brasil utópico, moderno, onde popular e refinado são polos que se atraem.

Contudo, aquilo que era promessa de felicidade nos anos 1950 tornou-se registro das ilusões perdidas apenas uma década mais tarde. Podemos também apontar uma "rotinização" desse projeto utópico no seu aspecto musical. Se os acordes alterados e caminhos melódicos quando do lançamento do LP Chega de Saudade eram inusitados, estranhos e arrojados, a neutralização das tensões e a estética anti contrastante da bossa nova fez dela um produto ideal para o uso mercadológico: não por acaso os "standards" de Jobim são extensivamente usados na trilha sonora de novelas, como música de elevador, supermercados e chamadas de telemarketing. Todas essas situações em que o conflito precisa ser apaziguado, silenciado. A síntese sem conflitos acaba funcionando como silenciadora deste numa sociedade em que a síntese renovadora não ocorreu. Tudo isso, ainda assim, não impede que as canções da bossa nova e suas dissonâncias persistam em irradiar promessas de um Brasil cuja modernidade é sinônimo de leveza, delicadeza, doce balanço. 


\section{Capítulo VII: Do CPC à Som Livre}

\section{Introdução}

Foi também entre o final dos anos 1950 e o começo dos anos 1960 que se intensificou a vertente do nacional popular entendido como projeto político de esquerda por grupos ligados ao Centro de Cultura Popular da União Nacional dos Estudantes (o CPC da UNE). Esses grupos se contrapunham à noção folclorista do popular, na qual a cultura popular era vista como uma tradição e um patrimônio que deveria ser preservado. Ao contrário, para o CPC, a cultura popular é vista como instrumento de transformação, uma forma de consciência política que deveria conduzir a ação política popular. Portanto, cultura denota aqui (Cf. Ortiz, 1985) um conjunto de atividades em prol de um projeto político, chegandose mesmo à máxima de que "fora da arte política não há arte popular". Contudo, devemos notar que, nesse projeto de cultura popular, fala-se do povo e para o povo, mas o povo ainda tem muito pouca voz por si.

Segundo Ortiz, no projeto cultural político promovido pelo CPC da UNE, no início dos anos 1960, a categoria central para a análise da realidade nacional era a alienação (ORTIZ, 1985, p.75). A situação de subdesenvolvimento e exploração da classe trabalhadora deveria ser superada primeiramente pela supressão da cultura alienada oriunda das classes dominantes. Desse modo, o nacional e o popular seriam faces da mesma moeda, uma cultura legítima contra uma cultura ilegítima e alienada:

\footnotetext{
Popular e nacional representam assim faces de uma mesma moeda; neste sentido, a prática do CPC implicaria a tomada de consciência da dependência dos países subdesenvolvidos com relação aos centros de decisões econômicas e culturais. Retoma-se de certa forma o argumento isebiano que focalizava o problema da dependência cultural em termos de alienação. A luta anti-imperialista, tema essencial das manifestações estudantis, penetra desta forma (...)o texto artístico, e pode, pedagogicamente, ser exposta para a grande massa. (ORTIZ, 1985, p.75)
}

Ainda segundo o autor, o equívoco desse pensamento foi, primeiramente, o de eleger arbitrariamente os valores de uma cultura "autenticamente" popular, e o de confundir uma cultura nacional com uma autêntica e emancipatória. Erro, uma vez que, após o golpe de 1964, se consolidaria uma cultura nacional, via indústria cultural, que reafirmaria a dominação das classes populares. Ou seja, uma cultura não é emancipatória pelo simples fato de ser nacional. 
[...] pela primeira vez o Estado estabelece uma política cultural a nível nacional. Surgem, assim, organismos do tipo EMBRAFILME, FUNARTE, projeto Minerva, TV Globo, que começam a atuar como administradores culturais. Toda manifestação popular tende, portanto, a ser inserida num espaço de subordinação que arbitrariamente é imposto a partir do alto. O problema se apresenta, pois, como relação de forças, não como alienação. (ORTIZ, 1985, p.78)

Mas voltando à canção popular, os músicos que incorporaram as posições do CPC se defrontaram com o desafio de superar a distância social e cultural da sua produção em relação ao gosto e à linguagem popular. Músicos como Carlos Lyra, Sergio Ricardo e Geralo Vandré não se submeteram completamente aos ditames do CPC, que em seu manifesto declarava que a arte deveria submeter a forma ao conteúdo, submeter os aspectos estéticos à função social e política que lhe cabia, a de conscientizar as massas (NAPOLITANO, 2001). Contudo, assumiram o desafio de conciliar o refinamento estético conquistado para a canção popular pela bossa nova com a proposta de arte popular, nacional e engajada. Ou seja, o desafio era conciliar o capital cultural recentemente conquistado pela bossa nova para a canção popular com engajamento político.

Em termos artísticos, os músicos da Bossa Nova identificados com as propostas do CPC promoveram uma "subida ao morro" e a retomada de formas e compositores do samba tradicional (Idem). Figuras como Cartola, Nelson Cavaquinho e Zé Kéti foram novamente trazidas para o centro das atenções e uma consequente ampliação do leque expressivo das canções que, a partir da bossa nova, ocupavam o centro do holofote. Segundo Napolitano, a utilização de materiais das formas tradicionais de samba, sem abandonar o intimismo da bossa nova, lançou as bases para o tipo de canção que se iria desenvolver nos festivais da canção. Artistas como Edu Lobo, Chico Buarque, Nara Leão e Elis Regina iriam trabalhar justamente um resgate das formas tradicionais da canção urbana, mas reinterpretadas pelo filtro estético da bossa nova.

Vale notar que todos esses artistas, fossem eles das vertentes mais politizadas, identificadas com o CPC, ou das vertentes mais abertas ao jazz e demais influências internacionais, todos encontraram o seu respectivo espaços nas gravadoras e tinham o seu trabalho distribuído pela venda de Lps, nas rádios e, principalmente, na televisão, a qual se fortalecia cada vez mais como o principal meio de difusão da produção musical na década de 1960. Nesse momento, início da década de 1960, não se sentia grandes contradições entre a intenção política, e até mesmo revolucionária de certas canções, e sua difusão pelos meios da indústria cultural. 


\subsection{A criação do CPC}

O Centro Popular de Cultura originou-se da cisão entre alguns participantes e o teatro de Arena de São Paulo, o principal deles sendo Oduvaldo Viana Filho (o Vianinha), enquanto o teatro excursionava pelo Rio de Janeiro, em 1961. Insatisfeitos com o público limitado que o teatro de Arena atraía (tanto em número quanto na faixa social, "burguesa") Vianinha aspirava pela "comunicação direta com as massas populares, através de um teatro feito diretamente para o povo" 110 . Os integrantes do Arena que decidiram permanecer no Rio de Janeiro pretendiam construir um teatro para as "massas", ao passo que o Arena, com seus 150 lugares, atraía apenas uma parcela politizada do público paulistano: "um movimento de massas só pode ser feito com eficácia se tem como perspectiva inicial a sua massificação, sua industrialização. É preciso produzir conscientização em massa, em escala industrial"111. Com esse objetivo, foi montada a peça "A mais valia vai acabar, seu Edgar" de Vianinha, a qual era musicada com canções de Carlos Lyra, no teatro da faculdade de arquitetura do Rio de Janeiro. Para a realização da peça, que tinha por intenção explicar didaticamente o conceito de mais-valia, foram buscar "consultoria" científica no ISEB (Insituto Superior de Estudos Brasileiros 1955-1964), e foi a partir desse contato que Carlos Estevam Martins, futuro redator do Manifesto do $C P C$, 1962, se aproximou do grupo.

Segundo depoimento do próprio Martins, a peça musical atraiu o interesse dos estudantes que circulavam pelo prédio da Faculdade, os quais assistiam à peça por mais de uma vez e ficavam para debater. Toda uma geração de futuros artistas e intelectuais estava presente (como Leon Hirszman, Arnaldo Jabor, Carlos Diegues), de modo que a ideia de criar um movimento cultural para a politização das massas, com o engajamento de grande número de artistas e intelectuais ganhou corpo, assim como o ISEB forneceu as bases teóricas para politização. Da proximidade com o ISEB veio também a influência de Paulo Freire e seu programa para a alfabetização de adultos, no qual alfabetização e politização, entendida como tomada de consciência dos problemas concretos da população pobre, caminhavam juntas. O programa de alfabetização de Paulo Freire e a difusão artística eram praticados também pelo Movimento de Cultura Popular (MCP) de Pernambuco, sob o governo de Michel Arraes, uma das grandes inspirações do CPC.

\footnotetext{
110 Depoimento de Carlos Estevam Martins publicado em: Arte em Revista v.2, n. 3., março 1980, p.77-82.

111 Do Arena ao CPC.
} 
A União Nacional dos Estudantes cedeu uma sala de sua sede ao então nascente CPC, o qual se organizou em seis grupos de trabalho $(\mathrm{GT})^{112}$ : GT de repertório (produção de peças teatrais), GT de Teatro, GT de Cinema (realização de filmes e atividades cineclubistas), GT de Espetáculos Populares (realização de espetáculos em entidades "de massa" como associações profissionais, sindicatos, clubes de bairro, favelas, faculdades etc.), GT da Produtora de Arte e Cultura (edição e promoção de livros e discos do CPC) e GT de Reestruturação (atender às necessidades de crescimento do CPC). Retomando o depoimento de Estevam Martins, o intuito do centro era, mediante o contato com entidades como sindicatos, associações e ida à periferias e favelas, entrar em contato com o "povo". No entanto, mostrou-se como "terrível decepção" a ilusão de que facilmente entrariam em contato com o povo, pois tanto a polícia impedia a realização de espetáculos na periferia, quanto os operários simplesmente não se encontravam nos sindicatos. Em depoimento ${ }^{113}$, Ferreira Gullar relembra que, nos espetáculos do CPC em fábricas e sindicatos, apenas alguns dirigentes e estudantes permaneciam até o fim, ao passo que trabalhadores não mostravam grande interesse pelas peças. Segundo Gullar, se fazia a discussão de como conquistar o interesse dos trabalhadores quando, em 1964, as atividades foram interrompidas pelo golpe militar.

Embora a ambição fosse atuar com e para as massas, o "povo", o CPC "acabou conquistando mesmo o público estudantil"114 quase exclusivamente. Embora não tenha "penetrado nas massas", o CPC, por intermédio da UNE volante (comitiva que percorreu os principais centros universitários de todo o país) construiu unidades em todo o país, num total de 12: "O impacto da UNE Volante em 1962 foi grande, numa época sem rede de televisão nacional, em que a malha viária ainda estava pouco desenvolvida e a comunicação entre os estados era difícil” (RIDENTI, 2014, P. 91). O próprio Caetano Veloso, em sua autobiografia, viria a lembrar-se das discussões sobre música popular brasileira feitas num teatro em Salvador, discussões que o impactaram, e da, em suas próprias palavras, "a mais graciosa" canção de protesto que surgiria, mais tarde, no Brasil.

O objetivo político do CPC (o qual discutiremos em maior detalhe a seguir a partir de seu Manifesto) era levar as ideias do socialismo e do anti-imperialismo para o maior

\footnotetext{
112 Relatório do Centro Popular de Cultura, apresentado no $1^{\circ}$ Encontro Nacional de Alfabetização e Cultura Popular, realizado em Recife, de 15 a 21 de setembro de 1963. Reproduzido do livro de Jalusa Barcellos, CPC da UNE: uma história de paixão e consciência. Rio de Janeiro, Nova Fronteira: 1994. Anexo, p. 441 a 456.

${ }^{113}$ Depoimento disponível em: http://forumeja.org.br/book/export/html/1720

${ }^{114}$ Depoimento de Carlos Estevam Martins op. cit.
} 
número possível de pessoas, valendo-se da arte como um instrumento para chegar à nova sociedade $^{115}$. A cultura popular seria instrumento da tomada de consciência revolucionária da sociedade brasileira (das causas da pobreza, das crises econômicas e do subdesenvolvimento), fazendo da obra de arte uma forma de ação numa luta que se pretendia revolucionária contra a alienação e o imperialismo econômico de grandes empresas internacionais atuando em solo brasileiro. Isso seria alcançado investindo conteúdos políticos "conscientizantes" nas formas artísticas populares: "levar ao povo o significado humano do petróleo e do aço, dos partidos políticos e das associações de classe [...] Para a nossa arte há de ser incomparavelmente mais pungente uma fogueira de toneladas de café do que as mesquinhas paixões de um marido traído" ${ }^{116}$. Combater a alienação, nesse contexto, era, em primeiro lugar, retratar os problemas do povo brasileiro, o que, segundo Gullar, levava necessariamente a encontrar a raiz desses problemas na "dominação imperialista". Como bem observou Roberto Schwarz (1969), as correntes de esquerda pré64 eram mais anti-imperialistas do que anticapitalistas. Por outras palavras, a alienação era associada aqui à situação colonial (Ortiz, 1985), à falta de uma consciência autenticamente nacional dos países economicamente dominados (e em geral ex-colônias) que fazia do pensamento desses países uma expressão moldada pelos países dominantes, sobretudo por meio das obras culturais importadas.

Um dos materiais produzidos pelo CPC foi o Violão de Rua: poemas para a liberdade, volume que reúne poemas engajados de autores como Ferreira Gullar, Moacyr Felix e Vinícius de Morais, com o intuito de "divulgar poetas que usam seus instrumentos de trabalho para participar, de modo mais direto, nas lutas em que ora se empenha o povo brasileiro, revolucionariamente voltado para as exigências de um mundo melhor e mais humano", segundo consta na contracapa. Talvez o mais famoso poema desse volume seja o "João Boa Morte: Cabra marcado pra morrer" de Gullar, o qual viria a dar o nome ao documentário de Eduardo Coutinho sobre as ligas camponesas. O poema narra a história de um "cabra marcado para morrer" por ousar desafiar o coronel e que, desesperado, à beira do suicídio, encontra nas ligas camponesas a força para viver: “Já vão todos compreendendo / Como compreendeu João / que o camponês vencerá / pela força da união. Que é entrando para as Ligas / que ele derrota o patrão / que o caminho da vitória / está na Revolução".

Outro material produzido pelo CPC, de relevo no panorama cultural brasileiro, foi o filme "Cinco vezes favela", que reúne 5 curtas, de 5 diretores, que retratam os morros

${ }_{115}^{15}$ Ferreira Gullar. Arte em Revista v.2, n. 3., março 1980, p. 83-87.

${ }^{116}$ Manifesto do CPC publicado em: Carlos Estevam Martins. A questão da cultura popular. Rio de Janeiro: Tempo Brasileiro, 1963. 
cariocas. Todos eles apresentam situações dramáticas de pobreza, fome, moradia e trabalho. O quarto episódio "Couro de Gato", de Joaquim Pedro de Andrade, musicado por Carlos Lyra e premiado na Alemanha e Itália (1962), retrata garotos da favela trabalhando pela cidade: jornaleiros, engraxates, vendedores de amendoim. Mas como o carnaval se aproxima e o preço do tamborim dispara, os garotos passam a caçar gatos, cujo couro será usado para os tamborins. Apesar da afeição e carinho que um dos garotos mostra pelo gato capturado, a pressão material obriga-o a entregá-lo para o abate.

$\mathrm{Na}$ música popular, o produto mais importante realizado diretamente pelo CPC foi o disco "O Povo Canta". Ele talvez seja o mais perfeito exemplo da problemática concepção do CPC a respeito da arte popular: uma arte considerada inferior, da qual o artista revolucionário (que não era povo senão por "opção") deveria servir-se para esclarecer a massa a respeito de seus próprios interesses e de sua própria condição ${ }^{117}$. Conforme escrito no encarte: "o compositor se faz o intérprete esclarecido dos sentimentos populares, induzindo-o a perceber as causas de muitas das dificuldades com que se debate". Uma vez que se partia do pressuposto de que a arte popular não possuía nem poderia possuir valor formal, sua única razão de ser era a pedagogia política. Assim são as canções de "O povo Canta", panfletos políticos musicados. A primeira faixa, a marcha "Subdesenvolvido", música de Carlos Lyra e letra de Francisco de Assis, a qual se tornou o hino do CPC, narra as sucessivas etapas de colonialismo econômico pela qual o Brasil passou: Portugal, Europa e Estados Unidos, além do latifúndio nacional. "João da Silva ou o falso nacionalista" canta, sobre uma base de bossa nova, o cotidiano de um cidadão comum que usa produtos importados em todos os momentos de sua rotina, do shampoo palmolive ao café nescafé, a gilette, a esso e a coca-cola ${ }^{118}$. A canção "Trilhãozinho" declara que, melhor do que receber a ajuda monetária de outros países, seria o Brasil investir na instrução, superar a alienação e assim produzir seu próprio "trilhãozinho". As duas últimas canções "Grileiro vem pedra vai”" e "Zé da Silva homem livre" são as únicas que não abordam o imperialismo econômico, mas sim a luta contra a espoliação da moradia e a exploração do trabalho, respectivamente. Mais uma vez, pode-se observar que o CPC associava alienação muito mais intimamente com a relação econômica internacional de imperialismo econômico do que com a exploração capitalista do trabalho, assim como identificava o nacional na luta popular contra os interesses estrangeiros. Ser popular era ser nacionalista e vice-versa.

117 Aprofundaremos esta questão logo adiante, na análise do Manifesto do CPC.

118 Note-se que Caetano Veloso se enganou ao declarar que "Alegria Alegria" é a primeira canção brasileira a mencionar a Coca-Cola. 
O CPC era movido, segundo Martins, pela disposição, pelo "fervor” que os artistas e intelectuais nutriam pela "causa", pela certeza absoluta que tinham de estar do "lado certo" da história e de que a vitória de sua causa era certa e inevitável; para tanto era necessário aumentar as fileiras, politizar a massa, engrossar o movimento que alcançaria, muito brevemente, a "transformação estrutural da sociedade brasileira". Nessa equação, a qualidade artística foi relegada a segundo plano, no entendimento de que qualidade estética e pedagogia política dificilmente andariam de mãos dadas: “ou se fazia pedagogia política, usando a arte para produzir conscientização política, ou então nada feito, voltava-se para o teatro de elite, a música de elite, a literatura, o cinema de elite" ${ }^{119}$. A opção foi por uma arte que se pretendia educativa, que "dava o seu recado", e era mais uma arma no front da luta revolucionária do "povo", ainda que o povo não tenha sido tão facilmente encontrado na busca do CPC.

Que a qualidade estética tenha sido relegada em nome da pedagogia política (o que, como veremos, decorre da análise francamente pejorativa que era feita da capacidade artística e da sensibilidade popular, ao mesmo tempo em que via no povo a qualidade de heróis revolucionários) é algo que a ideologia do CPC pretende justificar. Mas surpreendente é o fato do centro ter optado por ser uma empresa em vez de funcionar como um movimento social. Segundo Carlos Estevam Martins, o funcionamento em termos empresariais tinha a vantagem de "tirar o Estado da jogada" e não ficar, como os sindicatos, presos a ele pela dependência econômica. O CPC deveria ser uma empresa sustentada pelo "povo", e que por isso mesmo teria a obrigação de ser ouvida e compreendida por ele. Curiosamente, o centro foi uma empresa razoavelmente bem-sucedida, contando com 300 a 400 pessoas envolvidas, criando sua própria distribuidora de livros e discos (PRODAC) de modo tão bem-sucedido que atraiu o interesse da editora Civilização Brasileira ${ }^{120}$. Seus planos eram de contínua expansão de suas atividades em todo o território nacional quando o incêndio da sede da UNE em abril de 1964, durante o golpe militar, encerrou as suas atividades.

\subsection{Manifesto do CPC}

É necessário compreender com um pouco mais de profundidade as concepções teóricas e ideológicas que direcionaram as atividades do centro, cujo principal documento é o Manifesto do CPC redigido por Carlos Estevam Martins, em 1962. Compreendendo a cultura como parte da "superestrutura" social, em estreita conexão com o conjunto das

\footnotetext{
119 Op. cit.

120 Idem.
} 
relações de produção, o CPC acreditava distinguir-se da cultura alienada pela consciência de que a arte só poderia ser compreendida em sua relação com a base material. Uma vez que seria a partir desta s que se deveria orientar, o autor propõe que existem apenas duas alternativas para os produtores culturais, ou se é sujeito ativo na luta pela transformação dos suportes materiais, ou se é objeto passivo, ponto morto que é "determinado sem determinar". Ainda assim, dada a capacidade da superestrutura de reagir dialeticamente sobre as bases, as obras culturais poderiam servir ao propósito de serem "armas espirituais da libertação material e cultural do povo". Quando a consciência penetrasse na massa, aceleraria a ascensão dela ao poder.

A existência do artista de esquerda, cujo trabalho não é a "anestesia social", é possível, para o autor do Manifesto, pois a formação social não seria maciça, mas contraditória: haveria duas sociedades na sociedade, a velha e a nova, o imperialismo e o latifúndio de um lado, e a nação despertando para a conquista do seu futuro do outro. A nova sociedade, diz o Manifesto, é o povo: "novo é o povo e que há o novo onde está o povo e só onde está o povo". Portanto, o que distingue o artista do CPC é a clarividência que ele pretende possuir da arte em sua relação com a estrutura social, bem como sua opção de ser povo, de ser o novo transformador: "Os membros do CPC optaram por ser povo, ser parte integrante do povo, destacamentos de seu exército no front cultural".

É claro que essa opção por ser povo não viria sem sacrifícios. Se os membros do CPC optaram por ser povo, isto implica que eles não o são de fato, ou seja, pertencem a um estrato social diferente daquele, "o artista do CPC não pertence ao povo senão por espírito". Esse casamento espiritual exige fidelidade: se há divórcio entre artista e o povo, é necessário que o primeiro se policie para não o trair em sua atividade. Só quando a entrega não é total é que o engajamento seria sentido enquanto restrição à liberdade criativa. É preciso que o artista não sucumba aos hábitos arraigados de sua condição pequeno burguesa, que se imponha limites. Mas que fique claro, é o criador engajado quem proíbe a si mesmo de trair a classe revolucionária que ele desposou.

Contudo, se o casamento do artista engajado com o povo tem um futuro promissor, a cultura popular com a qual ele deve manter relações não é lá muito atrativa. O Manifesto postula a existência de três artes do povo. A primeira é a arte do povo: produto das comunidades economicamente mais atrasadas, artista e público não se distinguem e suas obras são tão primárias que não passam de uma mera ordenação dos dados na consciência popular atrasada (!). Já a segunda, a arte popular, apresenta divisão entre artista e público e é realizada nos grandes centros urbanos. Esta não passa, segundo o Manifesto, de um 
passatempo inconsequente e escapista, ela é a "produção em massa de obras convencionais cujo objetivo supremo consiste em distrair o espectador em vez formá-lo”. Segundo o CPC, nenhuma dessas duas formas de arte - as quais são as únicas que ele reconhece enquanto advindas do povo - se credenciam como experiência legítima no campo da arte, nem merecem a denominação de popular, pois expressam o povo apenas em suas manifestações fenomênicas não em sua essência. Apenas a arte popular revolucionária proposta pelo CPC se defronta com a essência do povo: a privação do poder em que se encontra o povo enquanto massa dos governados. Apenas a partir dessa premissa se poderia ser revolucionário e popular, pois ser povo é se identificar com sua aspiração de tomar o poder e deixar de ser povo. Ser povo é engajar-se na luta política na qual o povo supera a si mesmo, de modo que “fora da arte política não há arte popular". Seria uma verdade que paira acima de qualquer contestação o fato de não haver métodos distintos para se tomar o poder e para fazer arte popular: ambos teriam de ser feitos a partir das mesmas premissas.

Notemos de passagem que o povo e suas manifestações culturais, no manifesto, aparecem como portadores de qualidades exclusivamente negativas: povo é miséria, ignorância, falta de poder. Tanto é assim que o autor não nega a superioridade da arte de minorias no aspecto formal. $\mathrm{O}$ artista de minorias dirigir-se-ia a um público de condições culturais idênticas (?) às do artista. Ele não precisaria preocupar-se com a comunicabilidade de sua arte pois, se o seu público não está apto a compreendê-la, ele que se eduque para isso. Já o artista revolucionário, ao se dirigir ao povo (o qual é no Manifesto, em termos culturais, o repositório do atraso e da bestialidade), faz uma arte que em nada teria a ver com as duas outras artes do povo, mas delas necessita. Uma vez que ele se dirige a um público "artisticamente inculto" e "incapaz de participar da problemática artística da arte", o artista revolucionário deve limitar-se às formas de expressão inferiores para poder fazer-se comunicar. Uma vez que o Manifesto parte do pressuposto que o artista revolucionário pertence a um estrato cultural superior ao do público, ele não pode ir além do limite que lhe é imposto pela capacidade desse público; "nossa arte só irá aonde o público consiga acompanha-la". O artista revolucionário deveria recolher, num trabalho de campo, o material expressivo do qual se servirá, aprender a sintaxe das massas para infundi-las com conteúdo de pedagogia política. Qualidade artística é, para o autor do Manifesto, tomar consciência da necessidade e da urgência da revolução brasileira.

Em um texto tão profundamente antipopular, é mesmo incrível que se diga enxergar no povo a "qualidade heroica de futuros combatentes do exército de libertação nacional e 
popular”. Não fosse a imaginária guerra futura de libertação nacional, é difícil compreender o interesse por um povo retratado de maneira tão repulsiva.

\subsection{Críticas ao Manifesto}

A principal crítica redigida ao Manifesto do $C P C$ é provavelmente o texto de Marilena Chauí, em seu $11^{\circ}$ seminário sobre o nacional e o popular na cultura brasileira, dedicado aos Cadernos do Povo e ao Manifesto do CPC. Segundo a autora, a linguagem do Manifesto opera com maniqueísmos e estereótipos (o povo, a nação, a elite, o artista da minoria, o artista revolucionário, entidades que desfilam como fantasmas, descarnadas de material histórico que lhes dê substância). Ao mesmo tempo, também no plano conceitual, o texto opera de modo normativo e impositivo, jamais demonstrando como chega às suas premissas. Ele se dirige ao povo e ao interlocutor como dirigentes, comandantes. Sintomaticamente, o interlocutor do Manifesto não é o povo, mas o intelectual e o artista de elite, os quais ainda não optaram por "ser povo", e para os quais ele se esforça em demonstrar a superioridade da arte revolucionária. Não conseguindo fazê-lo em termos formais e de qualidade estética, tudo se justifica em nome da vindoura revolução, sem a qual o artista do CPC não teria motivo algum para se interessar pelo povo. Já Heloísa Buarque de Hollanda (1980) observa que, ao adotar a opção moral de ser povo, o artista do CPC cria uma linguagem que se pretende popular, mas não passa de uma ficção, construída com moralismo e disciplina. Uma linguagem celebradora, ritualizada, exortativa, codificada, esquemática.

É o que se pode claramente observar, por exemplo, nas canções de "O povo canta", canções que, retrospectivamente, não marcaram a história da música popular, numa época em que ela gozava de especial prestígio. Quando se fala de canções engajadas ou de oposição ao regime militar, lembra-se muito mais facilmente de nomes como Nara Leão, Chico Buarque ou mesmo de Carlos Lyra e Sérgio Ricardo, de canções não produzidas diretamente para o CPC. As canções como "Subdesenvolvido" simplesmente não convencem, não seduzem o ouvinte, não há a eficácia e o encanto típicos da linguagem cancional. À luz das canções de "O povo canta" e das proposições do Manifesto, podemos apontar o que talvez seja o ponto mais problemático do CPC: o pressuposto de que a arte popular é inferior e sem nenhuma qualidade formal resultou em produções que, no fundo, subestimam tanto a potência criativa da arte popular quanto a importância da estética para a eficiência da persuasão que, afinal de contas, subjaz a toda forma de comunicação. Pretendendo ser o intérprete esclarecido do povo, o CPC e seu Manifesto realizam uma ofensa implícita ao povo que pretendem esclarecer, tratando-o como um boçal. Em nenhum outro momento da 
canção popular abordado neste trabalho houve uma visão tão negativa do povo e da arte popular (da qual faz parte a canção) quanto esse.

\section{A canção de protesto pré-1964}

Em depoimento, já em 1980, Carlos Estevam Martins defendeu a produção do CPC apesar dos textos a partir dos quais se criticou esta proposta de arte política: "a vida do CPC foi incrivelmente diferente dos textos"121. Ironicamente, o texto no qual se centram as críticas ao centro é o manifesto escrito pelo próprio. Mas de fato, ao contrário da proposta de "aprender a sintaxe das massas" para investi-la de outro conteúdo (de pedagogia política), os temas do nacional popular na canção brasileira foram investidos na linguagem popular refinada cujo grande paradigma era a bossa nova. Esta, feita pela síntese de dois elementos sintáxicos distintos, a harmonia anti-contrastante e "atonal" do jazz e a estilização da batida do samba em seu elemento mais irregular, o tamborim. A linguagem cancional da bossa nova, síntese de um referente musical popular e nacional com procedimentos internacionais e refinados (para além do jazz, o romantismo e impressionismo franceses), veiculava letras no mais das vezes apolíticas. Como vimos com Tatit (2014), a linguagem da bossa tendia à musicalização, à leveza e mesmo à dessemantização do elemento textual, pois o peso semântico poderia atrapalhar sua proposta de leveza.

Não obstante, foi pelas mãos de figuras como Carlos Lyra, Sérgio Ricardo, além de Vinícius de Morais, Edu Lobo e Nara Leão que os temas do nacional popular entraram na canção. Mas não nas formas mais populares, e sim no (inter)nacional-refinado-popular da bossa. Os temas dos textos passaram da temática "amor, sorriso e flor" para o enaltecimento afetivo do povo brasileiro, o que fez mais de um pesquisador afirmar um certo "romantismo" na proposta cancional inspirada pelo nacional popular cepecista. Marcelo Ridenti (2014) fala de um "romantismo revolucionário" em toda a produção cultural engajada dos anos 1960, do teatro de arena ao oficina, do cinema novo à literatura de Antônio Callado e, evidentemente, na canção de protesto. Seria um romantismo revolucionário pois elementos de um passado idealizado, do homem comum, do campo ou das favelas, eram recuperados para a proposta do "novo homem", do futuro utópico que se procurava construir pela revolução social ${ }^{122}$.

\footnotetext{
121 Depoimento de Carlos Estevam Martins publicado em: Arte em Revista v.2, n. 3., março 1980, p.77-82

122 Proposta que, ao nosso ver, corre o risco de alargar por demais a noção de romantismo a ponto de absolutamente tudo poder ser associado a ela. De fato, o texto que serve de referência a Ridenti, de Löwy e Sayre (1995), pretende colocar sob a rubrica de romantismo praticamente todos os movimentos culturais que, a partir do século XIX, tiveram alguma dimensão utópica, chegando a oximoros tais como "romantismo
} 
Menos idealizando o passado do que vendo no homem do povo, seja ele do campo ou da favela, o "novo", (afinal, como escreveu Martins no Manifesto, “o novo é o povo”), cancionistas buscaram reafirmar a brasilidade e temas que celebravam as qualidades do povo, sem abandonar as conquistas formais da bossa nova. Isso, por outro lado, equivale a dizer: sem abandonar a nova posição social que a bossa conquistou, uma posição elitizada quando comparada ao samba de morro ou à música sertaneja e nordestina. A mesma fração culta e cosmopolita que conquistara uma nova posição cultural no panorama musical brasileiro encarregou-se da divulgação e ampliação do "mercado consumidor" de um imaginário nacional popular.

Ao mesmo tempo, a "sintaxe das massas" foi pesquisada e valorizada, mas também filtrada pelo paradigma da bossa (Napolitano, 2001). Edu Lobo foi talvez o grande paradigma da pesquisa formal da música folclórica brasileira, reinserindo-a nas formas populares e refinadas da canção de protesto, vide a premiada Ponteio. Por outro lado, figuras como Zé Ketti, João do Vale, Clementina de Jesus e mesmo Cartola foram promovidas e popularizadas em faixas sociais mais amplas pelo esforço do CPC (Idem). Uma vez que não havia um projeto específico para a canção, ela se realizou através de matizes poéticos e políticos muito distintos (Contier, 1998). Como se pode depreender de um depoimento de Carlos Lyra, o qual chegou a ser diretor do departamento musical do CPC, havia dentre os criadores consciência a respeito das suas relações com a arte popular, bem como das implicações de sua posição social. O mesmo Carlos Lyra que compôs "Subdesenvolvido" sabia que sua arte não seria, apesar das intenções, uma arte do povo, mas sim uma arte para o povo, que buscava alcançá-lo:

\footnotetext{
(...) Faço bossa-nova, faço teatro. Mas, da mesma forma que não acho que o teatro que a gente faz seja um teatro do povo, a minha música, por mais que eu pretenda que ela seja politizada, nunca será uma música do povo. Tudo pode ser feito com essa intenção de chegar ao povo, um teatro para o povo, uma música que busque a participação, a integração popular. Mas, classificá-los como arte popular, aí já é outra história (LYRA apud CONTIER, 1998)
}

revolucionário", "romantismo fascista", "romantismo conservador", "romantismo jacobino democrático". Se elementos tão disparatados podem ser associados ao termo "romantismo", qual teor explicativo essa categoria teria? A proposta dos autores, de que todos os elementos que recusam a modernidade em nome de uma nostalgia melancólica do passado, seriam "românticos" nos parece por demais imprecisa.[O que seria "romantismo", do seu ponto de vista?] 
Carlos Lyra, além de ter mantido estreita relação com o CPC (o que pode ser visto pelo grande número de peças de teatro e filmes produzidos pelo centro cuja parte musical coube a Lyra, além do fato de ele ter sido diretor musical da unidade do Rio de Janeiro), pode ser considerado como um caso exemplar do compositor engajado pré-1964. Sintomaticamente, seu primeiro álbum intitula-se Carlos Lyra - Bossa Nova, surgido no mesmo ano de Chega de Saudade, 1959, o que já indica o quanto a canção de protesto brasileira esteve umbilicalmente unida à Bossa. Aliás, há duas canções de Lyra em Chega de Saudade, "Lobo bobo" e "Maria ninguém". A primeira, canção exemplar da leveza bossanovista, narra a propositalmente pueril história de um lobo que sai para caçar o seu jantar, mas encontra uma "chapeuzinho de maiô", jura-lhe amor e hoje "não janta nunca mais", retrato do cotidiano do flerte nas praias da zona sul. "Maria ninguém", por sua vez, já resvala na semântica do nacional popular, tematizando a figura da "Maria" que, apesar de não ser ninguém, é “um dom que muito homem não tem”. Em 1963, no álbum em que Lyra adentra de vez a temática engajada sem abandonar a bossa (Depois do Carnaval), surge outra $\operatorname{Maria}^{123}$, a "Maria do Maranhão":

\author{
Maria, pobre Maria \\ Maria do Maranhão \\ Que vive por onde anda \\ E anda de pé no chão \\ Maria desceu escada \\ Atravessou o país \\ Procurava muito pouco \\ Muito pouco, ser feliz \\ Nem feliz queria ser \\ Que feliz não pode ser \\ Quem anda pelas estradas \\ Atravessando o país \\ Maria, pobre Maria \\ Maria do Maranhão \\ Que vive por onde anda \\ E anda de pé no chão \\ Maria seguiu estrada \\ A estrada de uma estrela \\ Maria não viu a estrela \\ Maria é só na estrada \\ Mas muita gente seguiu \\ A estrela que ela não viu \\ E vai dizer pra Maria \\ Que tudo tem solução
}

\footnotetext{
123 Já em 1967 Augusto de Campos defendeu Alegria Alegria de Caetano Veloso contra a enxurrada de Marias e violas nas canções dos festivais.
} 
Até mesmo pra Maria
Maria do Maranhão
Que vive por onde anda
Que anda de pé no chão

Em tom menor, a canção apresenta a curva melódica típica da passionalização: percursos de busca e vagueia pelo campo da tessitura, em perfeita consonância com a busca da Maria, a retirante do nordeste de pés no chão pela estrada. Relação mais complicada entre curva melódica, arranjo e letra é a canção Influência do Jazz, provavelmente o maior sucesso da carreira de Lyra. A letra da canção surgiu da observação de que músicos brasileiros como João Gilberto, Vinícius de Morais balançavam de um lado para o outro quando tocavam, ao passo que Ray Charles e demais jazzistas americanos balançam pra frente e pra trás: "Essa foi, de repente, aquelas sacadas que a gente tem, que de repente não tem nada a ver, mas que era engraçado era" 124 . Assim foi composta a letra que critica a influência do jazz no samba brasileiro, presença intensificada pela própria bossa nova da qual Lyra fazia parte. O balançado do jazz prejudicaria o balançado do samba, e a salvação seria voltar para o morro para se livrar da má influência. A ironia está em que a curva melódica temática é uma das mais envolventes e dançantes da história da bossa nova, sendo ela totalmente "jazzificada". Segundo o próprio Lyra, muitos músicos influenciados pelo jazz, como Sérgio Mendes e Simonal regravaram a música sem dar menor importância para a "propaganda subliminar", nas palavras de Tom Jobim, da letra. Ainda mais irônico ainda foi o fato da canção ter sido apresentada duas vezes no fatídico show do Carnegie Hall, de 1962. Na plateia, uma miríade de músicos de jazz (Stan Getz, Charlie Byrd, Herbie Mann) receberam muito bem uma canção que pretendia criticar a influência do jazz, e acabou por tornar-se um standard do samba-jazz, executada e regravada por jazzistas em todo o mundo. Como se não bastasse, essa canção que foi apresentada ao CPC como exemplo da arte engajada, em seus interlúdios musicais entra pela rumba cubana, ao passo que na terceira estrofe diz "No afro-cubano vai complicando, vai pelo cano vai". Segundo o próprio Lyra, nessa passagem também há uma crítica à influência de Cuba na música brasileira. Realmente, uma complexa relação entre sentidos denotados e conotados pela letra, entoação, harmonia e arranjo, numa canção que explode em ambiguidades envolventes e dançantes:

Pobre samba meu

Foi se misturando se modernizando, e se perdeu

E o rebolado cadê?, não tem mais

Cadê o tal gingado que mexe com a gente

${ }^{124}$ Depoimento de Lyra retirado de: http://osomdovinil.org/carloslyra-depoisdocanaval 


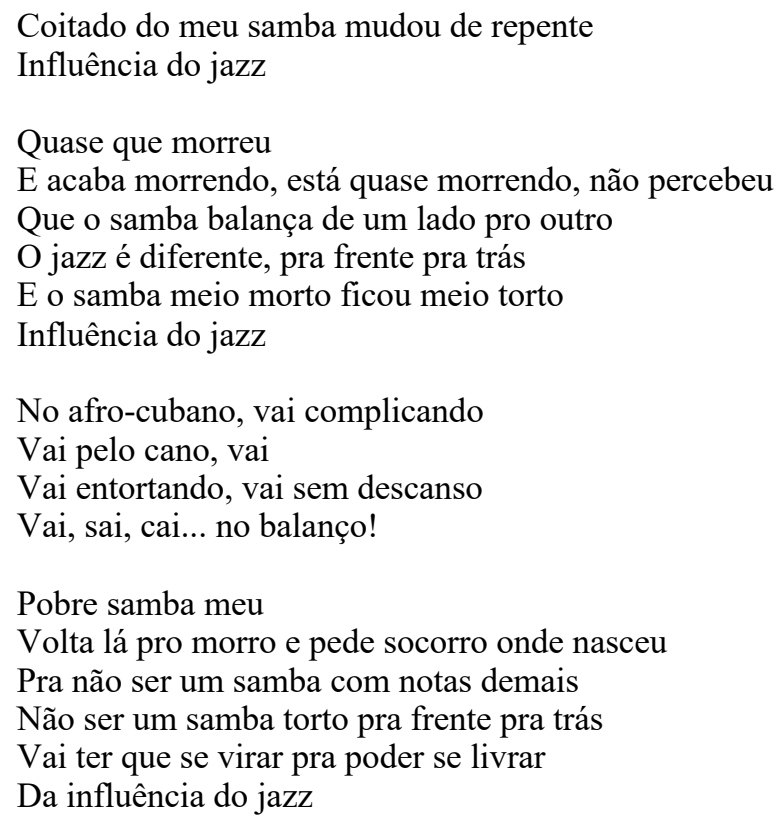

O álbum de 1963 ainda conta com outras canções engajadas, como "O melhor mais bonito é morrer", escrita com o próprio Vianinha para a peça A mais valia vai acabar, seu Edgar, canção que versa sobre um trabalhador pobre e desempregado, sem opções, considera a morte melhor, pois ela pelo menos dará trabalho para outros trabalhadores como o coveiro, carpideiro e vigário. Já a "Marcha da quarta-feira de cinzas”, outra das mais famosas canções de Lyra, alude apenas indiretamente ao tema da revolução social, às "promessas de luz" que existem e, portanto, apesar das tristezas "é preciso cantar". O estilo indireto de alusão tonarse-ia uma marca registrada da canção de protesto após o golpe de1964, devido à censura. A própria "Marcha da quarta-feira de cinza" foi inserida na peça Opinião, onde adquiriu imediatamente a conotação de oposição ao regime militar, apesar do qual seria preciso cantar.

Outra temática recorrente na cultura engajada do $\mathrm{CPC}$ era o olhar cético quanto à religião, a qual enfraqueceria o ímpeto revolucionário popular. Tal visão aparece com muita força no filme clássico do então nascente cinema novo Os fuzis, de Ruy Guerra, 1964: o campesinato nordestino morre de fome e segue um profeta com seu "boi santo", ao passo que no vilarejo um grupo armado do exército é convocado para proteger as mercadorias do armazém que devem ser transportadas para outra cidade, enquanto o povo apático e morrendo de fome apenas observa a abundante comida. Ao final do filme, morre o boi e o povo ataca a sua carne: desfazem-se as ilusões e o povo, simbolicamente, finalmente reclama os seus direitos. Temática semelhante aparece nas canções "Borandá" de Edu Lobo e "Esse mundo é meu" de Sérgio Ricardo: 
Edu Lobo "Borandá" (trecho):

Deve ser que eu rezo baixo

Pois meu Deus não ouve não

Vam' borandá

Que a terra já secou, borandá

É, borandá,

Que a chuva não chegou, borandá

Já fiz mais de mil promessas

Rezei tanta oração

Deve ser que eu rezo baixo

Pois meu Deus não ouve não

Sérgio Ricardo, "Esse mundo é meu” (trecho):

Fui escravo no reino

E sou

Escravo no mundo em que estou

Mas acorrentado ninguém pode

Amar

Saravá Ogum

Mandinga da gente continua

Cadê o despacho pra acabar

Santo guerreiro da floresta

Se você não vem eu mesmo vou

Brigar

A defesa da cultura nacional, de certos padrões de brasilidade (samba e ritmos regionais como os estilos autenticamente nacionais), a exaltação das figuras do "povo" (como as "Marias", os trabalhadores e os favelados) bem como alusões, ainda que distantes, da revolução social são temas caros ao CPC que penetraram na canção popular. Como já repetimos, mesmo artistas como Carlos Lyra, membros do CPC, não abriram mão da posição social que a bossa nova havia conquistado para a canção popular, e assim como antes acontecera com o teatro de arena, e depois aconteceria com os espetáculos Opinião, Arena canta Zumbi, Liberdade Liberdade, a canção engajada circulou sobretudo entre frações intelectualizadas do público consumidor de cultura popular.

O paradoxal resultado do engajamento político foi "adubar o campo", consolidar a demanda para produtos culturais os quais a indústria fonográfica, que se viria s consolidar com os festivais da canção e a infraestrutura instalada pela ditadura militar, soube aproveitar. O engajamento cepecista consolidou no público jovem e estudantil, de relativo poder econômico e capital cultural, o gosto pelas "coisas nossas" populares, sem o qual a MPB enquanto segmento de mercado não teria o sucesso avassalador da era dos festivais, assim como as canções, filmes e peças de teatro de teor político tiveram seu público consumidor consolidado pelos esforços dessa década. 


\section{O golpe civil-militar}

Autores como Renato Ortiz, Marcos Napolitano e Heloísa Buarque de Hollanda são unânimes na constatação de que, após o golpe, a cultura engajada teve suas pontes com as associações de classe (partidos, sindicatos etc.) cortadas. Como resultado, ela passou a realizar-se no circuito do mercado (teatro, gravadoras, cinemas, concertos, festivais...) onde obteve um consistente sucesso. O golpe civil-militar de 1964 trouxe, portanto, duas consequências imediatas para os produtores de canção popular. Primeira: o corte dos elos do artista engajado com as organizações políticas como o CPC da Une, uma vez que tais organizações foram postas na ilegalidade. A segunda decorre do fato de que a prioridade do governo militar foi perseguir e destruir as organizações políticas opositoras, restando, até a promulgação do AI-5, em 1968, uma relativa liberdade de criação e expressão na área da cultura. Esta tornou-se, portanto, um dos últimos refúgios para a atuação da esquerda nacional e um dos seus únicos espaços de atuação possível (ORTIZ, 1988).

Desse modo, instaurou-se com o golpe de 1964, uma ruptura no modo de organização social da esfera cultural. Entrou em cena um processo de racionalização das políticas governamentais e das técnicas de planejamento, processo que se estendeu para todas as áreas governamentais, com a criação de entidades como o Conselho Federal de Cultura, Instituto Nacional do Cinema, EMBRAFILME e FUNARTE (Ortiz, 1988, p.116). Com isso, o mercado cultural brasileiro adquiriu um volume e uma dimensão nacional muito mais abrangente. Por exemplo, a produção de livros, entre 1966 e 1988, cresceu de 43,6 para 245,4 milhões de exemplares anuais (ORTIZ, 1988, p.122). Já na indústria cinematográfica, havia uma média de 32 filmes anuais entre 1956 e 1966, ao passo que em 1980 foram produzidos 103 filmes (ORTIZ, 1988, p.124). No mercado fonográfico, entre 1967 e 1980 houve um crescimento de $813 \%$ na venda de toca-discos, e entre 1970 e 1976 um crescimento de $1375 \%$ no faturamento das empresas fonográficas (ORTIZ, 1988, p.127).

O planejamento colocado em prática pelo regime militar seguia a ideologia da Segurança Nacional, na qual a cultura era vista como "cimento da solidariedade orgânica da nação”. Segundo Ortiz:

Ao definir a integridade nacional enquanto "comunidade", o Manual da Escola Superior de Guerra retoma os ensinamentos de Durkheim e mostra a necessidade da cultura funcional como cimento de solidariedade orgânica da nação. A noção de integração, trabalhada pelo pensamento autoritário, serve assim de premissa a toda uma política que procura coordenar as diferenças, submetendo-as aos 
chamados Objetivos Nacionais. No entanto, a ideologia autoritária não se contenta com as categorias durkheimianas e vai além; aqui vale a pena citar: "No Estado de Segurança Nacional, não apenas o poder conferido pela cultura não é reprimido, mas é desenvolvido e plenamente utilizado. A única condição é que esse poder seja submisso ao Poder Nacional”. Isto significa que o Estado deve estimular a cultura como meio de integração, mas sob o controle do aparelho estatal. (ORTIZ, 1985, p.82)

Caberia ao Estado "dar as diretrizes e prover as facilidades" para a implantação da infraestrutura das telecomunicações no Brasil, as quais, no entanto, seriam exploradas por empresas privadas. Ao Estado caberia ainda "normatizar e regulamentar" a vida cultural, promovendo, via mercado, uma significativa expansão da produção e difusão de bens culturais, ao mesmo tempo em que exercia sobre eles uma forte repressão ideológica. Foi nesse período, que se estendeu de 1964 a 1980, que se consolidaram os grandes conglomerados de comunicação de massa no Brasil, num movimento de monopolização e centralização do poder em escala nacional, como, por exemplo, as empresas fundadas por Victor Civita (Editora Abril) e Roberto Marinho (TV Globo).

Em suma, o regime militar não apenas oprimiu e censurou as manifestações políticas e culturais opositoras ao regime. O seu papel na organização da vida cultural brasileira não se deu apenas no sentido de supressão. Ele colocou em marcha uma nova forma de organização e planejamento da vida cultural, instalou a infraestrutura necessária para o moderno mercado de bens culturais e garantiu que seria dentro da forma mercadológica que a vida cultural brasileira seria exercida.

No período que vai de 1964 a 1968, não foi percebida como problemática a atuação do músico engajado dentro da nova organização mercadológica da cultura. O mercado se abria para a MPB nacionalista e engajada, ao mesmo tempo que outros espaços, como o CPC da UNE, eram fechados pelo regime (NAPOLITANO, 2001). A bossa nova aportou no circuito universitário paulistano com shows no teatro Paramount, mas, depois do golpe de 1964, o novo gênero não era apenas uma nova moda e expressão da utopia de um Brasil moderno, mas também passou a ser percebido como forma de resistência ao regime militar. A música popular "moderna" ia então ampliando o seu público nacional e valorizando o seu capital simbólico. Esse foi um rearranjo de posições importante para a explosão de popularidade e o aumento de capital simbólico que a canção conquistaria a partir dos festivais de 1966. 
Nos anos 1960, foi a televisão, sobretudo o canal Record, o meio responsável pela massificação do público da canção popular. Marcos Napolitano argumenta que não é correto dizer que houve "cooptação" dos músicos pelo mercado - nesse momento, representado sobretudo pela televisão - uma vez que a aspiração por um público amplo, que abrangesse todo o território nacional e todas as classes sociais era um desejo e uma demanda dos próprios músicos, principalmente daqueles ligados ao nacional popular e ao CPC da UNE. O desafio do músico engajado após a bossa nova era o de conciliar as novas conquistas estéticas com a pedagogia política das classes populares. Uma vez que a canção tornou-se atração na televisão, apresentou-se a esses músicos a oportunidade de utilizar esses meios difusores para atingir um público muito mais amplo do que antes. A televisão, segundo Napolitano, não apenas consolidou a mudança do lugar social da canção iniciado pela bossa nova, como ampliou quantitativamente audiência e modificou sua composição qualitativa. A canção deslocou-se dos círculos boêmios e universitários para uma audiência de massas. Ampliaram-se não apenas as faixas sociais, mas também as faixas etárias que passaram a consumir música popular engajada e modernizada. Segundo o autor:

[...] nascia um novo conceito de MPB, herdeira da bossa nova, mas que incorporava gêneros, estilos e obras que extrapolavam os paradigmas delimitados pelo movimento de 1959. Esse processo não pode ser desvinculado da crescente importância da TV e se revestiu de uma complexidade que não pode ser reduzida a um fenômeno de expropriação cultural por parte da classe média, como afirma Tinhorão. [...] Os acontecimentos subsequentes da música brasileira, entre 1967 e 1968, marcados pelo jogo simultâneo de delimitação e transmigração de faixas de público, estabelecimento e rompimento de tradições culturais, simbiose de realização comercial e esforço de conscientização política, é consequência direta desse fenômeno de divulgação musical via TV. (NAPOLIATNO, 2001, p. 82, grifos no original)

Com a modernização do mercado de bens culturais e a instalação de novos meios de comunicação de massa, a canção popular moderna, e engajada, espaço de oposição ao regime militar, foi, ironicamente, amplamente beneficiada pela infraestrutura instalada por esse regime. Ela passou então a ocupar uma posição privilegiada, em três campos que funcionam com lógicas distintas: o mercado, a política e a cultura. $\mathrm{O}$ acúmulo de capitais específicos a esses três campos propiciou à canção popular, no Brasil, o exercício de um protagonismo social e de um reconhecimento que ela raramente desfrutou em outros lugares, permitindolhe ocupar, sobretudo na era dos festivais da canção, uma posição proeminente na vida 
cultural do país : posição de cruzamento entre as mais diversas ambições, entre os mais diversos projetos políticos de modernidade brasileira e representações do Brasil.

\section{Os festivais}

A canção adquiriu o seu espaço na televisão primeiro com programas musicais no canal Record. Entre eles, O fino da bossa, que estreou no dia 17 de maio de 1965, estrelado por Elis Regina e Jair Rodrigues, e logo adquiriu um expressivo sucesso de audiência (NAPOLITANO, 2001). Segundo o historiador: "O clima de festa dançante predominava e as músicas representavam um panteão de compositores antigos e novos, desde que coubessem, de alguma forma, dentro das diversas correntes do Samba e outros gêneros "nacionais"' (NAPOLITANO, 2001, p.89). Este programa ajudou a estabelecer a linguagem da nova MPB, uma linguagem que mantinha vínculos com a bossa nova, mas ao mesmo tempo retomava o samba carioca e outros gêneros da canção popular representantes do "autenticamente nacional".

Contudo, a organização da cultura com base na forma mercadológica, embora tenha recebido formas artísticas criadas ao largo das suas estruturas, também não tardou a produzir, ela mesma, manifestações culturais mais adaptadas, "racionalizadas" conforme seu modo de funcionamento. Em outubro de 1965, apresentado por Roberto Carlos, Wanderléia e Erasmo Carlos, surgiu o programa Jovem Guarda, também na Record. Musicalmente, a jovem guarda limitava-se a "importar" formas do rock e do pop anglo-saxão, canções de comprovado desempenho comercial. Reproduzimos a seguir o texto do jornalista Tárik de Souza, recuperado por Marcos Napolitano, o qual explica como se deu a construção de um movimento musical diretamente dentro das engrenagens da indústria cultural, algo até então inédito no Brasil:

Carlito Maia, da agência de publicidade de Magaldi, Maia \& Prosperi, tinha a ideia de construir ídolos de consumo no Brasil. Seguindo padrões norte-americanos, pretendia, pela propaganda maciça, criar um mito para juventude (...) Um acontecimento - aparentemente sem nenhuma relação com a música - veio dar a Magaldi a oportunidade que esperava. A Federação Paulista de Futebol proibiu a transmissão direta dos jogos pela televisão e a audiência das emissoras, nos domingos à tarde, caiu verticalmente. O canal 7, TV Record de São Paulo, então na linha dos grandes musicais, resolveu programar um show de música jovem, que deveria se chamar os Reis do iê-iê-iê. Imediatamente, Magaldi, Maia e Prosperi entraram em ação, comprando o horário e contratando três cantores apresentadores fixos: dois homens (Roberto e Erasmo) e uma mulher (Wanderléa) (...) Sem vender o programa (mesmo porque, de início, os patrocinadores hesitavam em associar seus 
produtos àqueles 'delinquentes cabeludos', a agência assumiu todo o ônus financeiro e montou uma gigantesca máquina publicitária (...) Como um toque de ironia final, Maia denominou o programa de jovem guarda e registrou a marca, embora tirada de uma frase de Lênin (...) Em outubro de 1965 o programa estava no ar e em três semanas seria um sucesso absoluto (Souza apud Napolitano, 2001, p. 96)

Tem-se, com a MPB, uma produção musical que, oriunda de diversos espaços sociais de produção e em interlocução com a história dos gêneros da canção brasileira, usou e foi usada pelos novos meios de comunicação de massa. Já com a Jovem Guarda, está-se diante de um movimento musical criado pelos agentes dos novos meios de comunicação, com vista a atender em primeiro lugar os seus propósitos de lucro, e valendo-se de uma linguagem construída para atender a esse fim.

Os dois programas, O Fino da Bossa e Jovem Guarda, eram líderes de audiência em seus respectivos horários, ambos na TV Record. Observando o potencial da música na televisão, os canais Excelsior, Record e o governo da Guanabara promoveram, na segunda metade da década de 1960, uma série de festivais da canção, fazendo desse período a "era dos festivais". Em março de 1965, a TV Excelsior organizou o I Festival Nacional de Música Popular, vencido por Elis Regina, que interpretou a canção Arrastão de Edu Lobo e Vinícius de Morais. Em outubro de 1966, o governo da Guanabara organizou o I Festival Internacional da Canção (FIC), e também nesse mês foi organizado o II Festival de MPB da TV Record, que "superou todas as expectativas de público e consagrou um novo panteão de cantores populares" (NAPOLITANO, 2001, p. 154).

Pode-se dizer, em suma, que a televisão e os festivais cumpriram o papel de sondagem e de estruturação de mercado para as gravadoras (Napolitano, 2001). Testaram os artistas e as obras num público difuso, massificado, sem preferências completamente mapeadas.

\section{A estruturação da indústria cultural brasileira}

A canção popular brasileira, tanto na década de 1930 quanto na de 1960, momentos de intenso debate e reorganização institucional da vida cultural do país, foi influenciada por diferentes versões do pensamento do "nacional popular", o qual, seja sob o Estado Varguista, que desejava valer-se da cultura popular para legitimar-se perante a sociedade e fazer da canção popular um canal da propaganda do Estado, seja sob o CPC da UNE, que desejava valer-se da canção para fomentar o seu projeto de ação política, colocando-a a serviço de um 
projeto político. Como sublinha Renato Ortiz, a temática do nacional-popular e da identidade nacional tinham em vista um país a ser construído (1988). Mas, a partir da década de 1970, a modernização da sociedade brasileira impôs-se como uma realidade, um fato consumado apesar de todas as suas contradições, e não mais como um projeto a ser realizado.

Ainda segundo Ortiz, houve um relativo silêncio sobre a construção de uma cultura de massas no Brasil. O Estado autoritário teria desviado a análise dos críticos da cultura do que se passava estruturalmente na sociedade brasileira. Eles teriam focado apenas na censura e na ameaça de "desnacionalização" da cultura, mas não se concentraram na consolidação de um mercado de bens culturais no Brasil a partir da década de 1970. No caso da canção popular, vimos que o debate nos anos 1960 centrou-se em torno da sua como forma de conscientização das massas, da música como identidade nacional e consciência política, da estética de uma canção legitimamente nacional, mas a discussão sobre a consolidação de uma indústria musical no Brasil e das possíveis consequências da circulação da canção sob a forma mercadoria permaneceu fora do debate. Ao contrário, a entrada da música popular na televisão e a sua consagração nos festivais foi vista como algo positivo para essa forma artística e até mesmo para os grupos mais engajados na politização da canção, uma vez que a indústria cultural que se abria para a canção foi vista como uma forma eficaz de alcançar as massas.

Com a entrada dos militares no poder, houve a consolidação de um mercado moderno e a realização de uma modernidade brasileira pela inserção da economia no capitalismo internacional e a estruturação dos mercados culturais. O Estado autoritário foi o portador do capitalismo, o qual, a partir da década de 1960, superou a sua incipiência. Como já foi apontado, foi na década de 1960 que se formaram os grandes conglomerados que monopolizam os meios de comunicação no Brasil, como a Globo e a editora Abril, os quais só puderam desenvolver-se por conta do investimento feito em infraestrutura pelo regime militar, bem como pelo modelo de gestão da cultura, o qual possuía não apenas a sua face repressiva (a censura), como também promovia um modo de pensar e gerir a cultura pela via do mercado.

Esse desenvolvimento teve grande impacto no modo de organização da produção musical brasileira, alterando definitivamente o tipo de relação que até então havia se estabelecido entre música popular e os meios de difusão de massa. Nos anos 1970, houve um crescimento explosivo da indústria fonográfica brasileira: 
[...] Mas o que os números indicam é, sobretudo, o aumento do volume de vendas, que no período cresce de 25 milhões para 66 milhões de discos comercializados anualmente. (ORTIZ, 1988, p.127)

Seja na fonografia, no rádio, na televisão ou na imprensa, a parir da década de 1970 o mercado cultural brasileiro atingiu o grau de integração e racionalização característicos da indústria cultural.

\section{Reestruturação da indústria fonográfica}

Nas décadas de 1960 e 1970, as gravadoras s valeram-se dos festivais da canção para a formação de um "cast" estável de artistas. O “cast" designa o conjunto de artistas nos quais as gravadoras investem a longo prazo, uma vez que é mais lucrativo manter um quadro de artistas que vendam discos com regularidade do que confiar apenas nos artistas de sucesso intenso, mas de curta duração (DIAS, 2000, p.61). A formação desse conjunto de artistas que formava o panteão das gravadoras foi um primeiro passo na reestruturação do mercado fonográfico brasileiro, o qual também foi impulsionado pela presença do LP. A venda de um disco com várias canções favorecia a concepção de venda do trabalho de um artista, ao passo que, na venda de compactos, com apenas uma ou duas canções, o que se vendia não era o artista, mas a própria canção.

Além da infraestrutura implementada pela ditadura militar, a indústria fonográfica também foi favorecida, em 1967, pela isenção do Imposto sobre Circulação de Mercadorias a todas as empresas fonográficas que tivessem uma devida quantidade de artistas nacionais em seu catálogo (DIAS, 2000, p.62). Essa medida favoreceu especialmente as empresas estrangeiras que, se montassem um cast de artistas nacionais, poderiam distribuir seus produtos produzidos em outros países por um custo reduzido, o que contribuiu para a implantação da indústria mundial do disco no Brasil.

A canção popular já desfrutava, antes da década de 1970, da interação com diversos meios difusores, como a televisão e as gravadoras, na época dos festivais. Mas um outro tipo de interação começou a estabelecer-se nos anos 1970, quando os meios difusores começaram a investir de modo planejado na construção de ídolos de consumo (algo que já havia sido feito pioneiramente com Roberto Carlos), de forma a integrar a música/mercadoria num circuito mais ampliado e mais integrado de marketing. $\mathrm{O}$ exemplo do plano de lançamento da cantora Rita Lee é ilustrativo: 
A interação de vários setores da indústria cultural, a grande simbiose de valores culturais industrializados e mundializados e sua definitiva consolidação no Brasil dos anos 70, são exemplarmente observados na estratégia de marketing que lançou a cantora brasileira Rita Lee, então vocalista do grupo musical Mutantes, em carreira solo. Em 1970, o interesse de André Midani, presidente da Philips (a gravadora do grupo) em investir na artista, fez com que sugerisse seu nome para Lívio Rangan, presidente da Rhodia no Brasil, para estrelar um show de lançamento da coleção de tecidos da empresa, no início do referido ano. [...] Mas, em agosto do mesmo ano, surgiu o segundo espetáculo, mais vultuoso e elaborado, a partir do sucesso do primeiro. A Rhodia montou uma superprodução para o lançamento de sua segunda coleção, estrelado, da mesma forma, por Rita Lee que, simultaneamente, lançava seu primeiro disco solo. Tanto o show-desfile, quanto o disco, tinham o emblemático nome de Bild Up, que em inglês significa construir, mas em termos de mídia, significa construir, articular a imagem de um artista, ou de um produto, para que ele seja mais facilmente consumido e era, no fundo, o que eles queriam fazer com a Rita [...] A Rhodia montou um show que era o seguinte, uma artista jovem que era a Rita, que ia passar por um processo de bild up na indústria. Então a cantora ia ser uma modelo em começo de carreira, ingênua, que ia fazer contato com a agência de publicidade. Esse era o cenário do show. Uma agência de publicidade, onde as contas eram dos mais variados produtos, por exemplo, tinha um dentifrício, uma marca de carro, um cosmético. Vários produtos passam pela indústria, articulados naquela agência de propaganda e justamente, cada um dos produtos para os quais a agência ia bolando as propagandas, a Rita, como modelo, ia promovendo. E esses produtos eram aqueles que estavam pagando o show, eram os próprios patrocinadores do show. Para a época, uma coisa muito bem articulada. (CALADO apud DIAS, 2000 p. 67-68)

Ou seja, com a estruturação da indústria fonográfica no Brasil, em estreita conexão com outros setores, houve um estreitamento das relações entre o produto musical e outros produtos da indústria em geral. A canção, para chegar efetivamente aos ouvidos da grande massa, precisava então passar por mecanismos mais sofisticados e muito mais caros de divulgação, distribuição e marketing. Podemos notar a esse respeito, que surge na década de 1970 a gravadora Som Livre, da Rede Globo, que em poucos anos (1971-1976) tornou-se a líder de mercado com a comercialização de trilhas sonoras de novelas, valendo-se da vantagem de usar a sua própria estrutura de telecomunicações para a divulgação dos seus produtos (DIAS, 2000). Ou seja, estamos diante de uma forma de interação entre produção musical e meios difusores muito distinta das décadas anteriores.

As fusões das empresas fonográficas, tanto no plano nacional quanto internacional levaram a uma "concentração de poder em escalas sem precedentes" (ORTIZ, 2000), 
passando a dirigir sua atuação no controle dos canais de distribuição e de acesso à mídia. Uma das consequências dessa concentração do mercado foi a necessidade de retorno cada vez maior do investimento e de planejamento e segurança do retorno da quantia investida, uma vez que se tornava cada vez mais cara a colocação do produto no mercado em escala industrial, pois era necessário um investimento cada vez maior. Desse modo, tornou-se também progressivamente necessário um maior controle sobre as características do produto a ser lançado: padronização. Não tardou para que a própria indústria assumisse a criação musical:

\footnotetext{
$\mathrm{Na}$ época [anos 1930] o talento nascia naturalmente, nas boates, nos bairros, em locais absolutamente anônimos... Depois, eles [os talentos] ganhavam espaço nos meios de comunicação, eles eram conhecidos e só então vinha a gravação, que documentava aquilo e espalhava pelo Brasil... Isso ainda aconteceu até o final dos anos 60. Infelizmente, com o passar do tempo as grandes gravadoras assumiram a responsabilidade dessa produção e, como a máquina ficou grande demais, ficou tudo muito gigantesco, e essa máquina precisa estar sempre aquecida e sempre vendendo sem parar... eles perderam a paciência de lidar com o talento, e: "vamos inventar nós mesmos as nossas coisas”. Conclusão: isso resultou numa produção simplória, medíocre, que é uma coisa linear, uma coisa melódica, sem absolutamente nenhum talento... Mas que tem uma certa produção, um certo melodismo, um invólucro bonito de instrumentação e de produção. (MEDAGLIA apud FENERICK, 2007, p.78, grifos nossos)
}

Durante as décadas de 1970 e 1980, foi possível observar uma grande mudança no conjunto de questões que orientavam a prática musical era produzida e difundida pelos grandes meios de comunicação. As questões do nacional popular, a tropicália, a canção de protesto, a tradição..., todas essas posições perderam força uma vez que as questões decisivas para a produção de canções com ampla penetração nacional partiam muito mais dos departamentos das poucas gravadoras que dominavam o mercado do que do próprio campo artístico de produção. Fora o panteão de artistas consagrados nas décadas anteriores, os quais ainda podiam negociar com as gravadoras a linguagem de suas canções, elas davam espaço apenas para a linguagem musical por elas mesmas produzida com o objetivo de maximizar o retorno financeiro. Luiz Tatit fala de uma nova triagem na linguagem cancional brasileira promovida por agentes que não foram os artistas, a qual acabou por tornar a tríade SertanejoAxé-Pagode o carro chefe da indústria fonográfica nacional nos anos 1990, os estilos mais veiculados nos grandes meios de comunicação: 
[...] esta última [triagem] elegeu o consumo como critério maior para a caracterização de seus modelos. Os verdadeiros sujeitos da quarta triagem foram os representantes das empresas (diretores, produtores, e homens de mídia) que respondiam pelo perfil artístico dos grupos e pelos acordos com os veículos de divulgação. Os artistas em sua maioria eram tratados como peças de uma engrenagem que poderiam ser substituídas a qualquer instante sem causar prejuízos significativos à carreira do grupo. [...] Para selecionar os formatos ideais de uma canção que produzisse sentimentos passionais (como a sertaneja), ou que estimulasse a dança e alimentasse o espetáculo para a produção de imagens televisivas (como o axé e o pagode), enfim, que fosse apreciada "de longe", os agentes da quarta triagem tiveram que eliminar qualquer complexidade harmônica ou rítmica de seus produtos, bem como sinais de elaboração menos linear do conteúdo das letras. (TATIT, 2004, p.107-108)

Esta triagem foi especialmente restritiva quando, em 1980, a recessão econômica atingiu o Brasil. O país viveu anos de hiperinflação e o mercado de discos sofreu forte retração (DIAS, 2000, p. 81). Reencontramos, então, o cenário discutido no primeiro capítulo: a indústria fonográfica tornou-se impenetrável para artistas novos que almejassem produzir uma linguagem inovadora no campo da canção. Na correlação de forças entre artistas e meios de gravação/difusão, já não havia mais espaço para novos ingressantes que pretendessem levar adiante as posições criadas dentro do campo artístico de produção. A canção popular produzida na interlocução com a história do campo, a canção "consciente de suas possibilidades culturais" (como formulou Caetano) permaneceu como privilégio de poucos artistas eleitos, ou refugiou-se em circuitos independentes. 


\section{Capítulo VIII: Moderno, arcaico e mítico: o Brasil moderno e eterno na tropicália}

A tropicália talvez seja o momento mais debatido e tematizados nos estudos da canção popular. Já há uma bibliografia considerável a respeito das canções tropicalistas e das implicações políticas e históricas da sua estética, contando inclusive com a participação de figuras proeminentes da crítica cultural acadêmica, como Roberto Schwarz, e da arte erudita de vanguarda, como Augusto de Campos. Muitos dos que se debruçaram sobre a tropicália a consideram como o encerramento de um ciclo da canção popular, o qual se teria iniciado com a bossa nova: daí que "da bossa nova à tropicália" fosse a designação recorrente para a época mais crítica da MPB, período de ascensão da canção popular ao status de forma cultural refinada, de proeminência na esfera pública e de resistência ao regime militar, encerrando-se nas experimentações algo violentas e de alta densidade simbólica da tropicália. Ciclo que se fechou também (e o que não é um fator desimportante) pelo exílio forçado e censura impostas pela ditadura ${ }^{125}$.

Está claro que este trabalho, tendo escolhido como ponto de partida e sonda dos sentidos construídos em torno da noção de Brasil moderno na canção popular a figura de Arrigo Barnabé, não compartilha da visão de encerramento do ciclo "modernizante" da canção. Claro também deve estar que as noções de "ciclo" ou "linha evolutiva" da canção popular são sempre construções feitas pelo analista (no caso da "linha evolutiva", construída também pelos próprios agentes) a partir de fatores por ele selecionados e organizados de acordo com seu instrumental teórico, com vistas a obter mais clareza quanto aos sentidos e possíveis nexos causais no desenrolar dos fenômenos, cuja realidade empírica é sempre inesgotável e inapreensível em sua totalidade. Ou seja, a importância do "ciclo" que vai da bossa nova à tropicália poderia ser plenamente relativizada se escolhêssemos outros pontos de vista para enquadrar o fenômeno canção popular: clube da esquina, mangue beat, e o rap dos anos 90 são eventos da canção popular que desafiam a centralidade conferida à bossa e a tropicália, bem como às décadas de 1950 e 1960.

Ainda assim, este trabalho deve agora debruçar-se sobre a tropicália pois, não apenas ela foi de suma importância para desenvolvimentos ulteriores da canção (sobretudo Arrigo

\footnotetext{
${ }^{125}$ Fizeram parte da tropicália Caetano Veloso, Gilberto Gil, Gal Costa, Maria Bethânia, Tom Zé, os Mutantes, Torquato Neto, Capinan, os músicos eruditos Julio Medaglia, Rogério Duprat. Também viriam a se alinhar com as posições da tropicália os poetas concretos Augusto de Campos, Haroldo de Campos e Décio Pignatari. Cronologicamente, a tropicália surgiu com a apresentação das canções Domingo no Parque e Alegria Alegria no festival da canção de 1967. Ganhou fôlego com o álbum coletivo Panis et Circensis, desenvolveu-se ainda mais nos álbuns de Caetano, Gilberto Gil, vindo a extinguir-se após o exílio dos artistas entre, 1969 e 1972.
} 
Barnabé), como também foi nesse momento que se construíram noções que viriam a orientar a prática da canção nas décadas posteriores (a tal "linha evolutiva" e a importância assim conferida à inovação formal consciente no âmbito da linguagem da canção, não necessariamente vinculadas aos parâmetros do samba e da bossa nova). Mas acima de tudo, a tropicália certamente foi um dos momentos da canção em que a questão dos significados de um Brasil moderno tenha sido mais intensamente e propositalmente trabalhada. Os cancionistas da tropicália assumiram a tarefa de interpretar $n a$ linguagem da canção popular os sentidos do Brasil, num momento de aguda crise política e social (pós 64), o que certamente reforça a importância desse momento.

Segundo Caetano em Verdade Tropical (livro que será utilizado como bússola do tropicalismo), foi o choque provocado pelo filme Terra em Transe, de Glauber Rocha, o grande elemento deflagrador desse movimento ${ }^{126}$. Esse filme tematiza alegoricamente as forças sociais em crise e em choque no golpe de 1964, resume de forma brilhante muito do que estava em jogo para os agentes, sobretudo elementos culturais, do momento. É por isso que este capítulo se abre com uma análise do filme e a visão de Brasil que dele emerge: o choque fermentador da tropicália.

\section{Terra em Transe}

Terra em Transe, 1967, é o filme mais conhecido de Glauber Rocha, lançado apenas três anos após o golpe civil-militar de 1964. Ele inscreve-se na história brasileira como exemplar das experimentações vanguardistas típica dos anos 1960, mas também como fonte de reflexões sobre o impasse político em torno do golpe de 1964. Um dos muitos testemunhos do choque causado pelo filme no público da época foi registrado por Caetano Veloso em sua autobiografia: "Vi essa cena - e as cenas de reação indignada que ela suscitou em rodas de bar - como o núcleo de um grande acontecimento [...] a morte do populismo. [...] era a própria fé nas forças populares - e o respeito que os melhores sentiam pelos homens do povo - o que aqui era descartado como uma arma política ou valor ético em si” (VELOSO, 1997, p. 105). Mais adiante será retomado o comentário de Caetano bem como a cena que ele aborda. Por ora, basta notar que o filme de Glauber Rocha tocava nos nervos sensíveis de um país dilacerado, em crise violenta; e que a esquerda organizada, que se julgava perto de tomar o poder em nome do povo, se via então distante do poder e do povo.

126 "Se o tropicalismo se deveu em alguma medida a meus atos e ideias, temos então de considerar como deflagrador do movimento o impacto que teve sobre mim o filme Terra em Transe, de Glauber Rocha" Caetano Veloso. Verdade tropical. São Paulo: Companhia das Letras, 1997 p. 99. 
O relato do filme inicia-se com um plano panorâmico, no qual do mar se chega à terra, o país alegórico de Eldorado, com batuques africanos ao fundo (é interessante notar o aspecto sonoro do filme, que compõe uma narrativa à parte, paralela às imagens e palavras). Em seguida, com um ruidoso solo de bateria, temos um plano em um palácio, onde um político cercado por militares, clérigos, militantes e assessores está afundado no caos e prestes a anunciar sua renúncia: é o líder popular Vieira, que pressionado pelas tropas militares federais abre mão de sua candidatura à presidência. Abre mão também da possibilidade de uma resistência armada perante o golpe de Estado liderado por Diaz, a personificação quase diabólica do conservadorismo, do status-quo antipopular. Entra em cena o protagonista, o poeta Paulo Martins, toma a metralhadora em mãos e roga pela resistência armada. A câmera, que até então se movimentava intensamente por entre os personagens (a característica «câmera na mão» de Glauber Rocha) se fixa, ao passo que o protagonista assume o movimento incessante. O solo de bateria dá lugar ao silêncio e depois a um melancólico violoncelo. O líder popular Vieira dita suas últimas palavras enquanto candidato para sua assistente Sara (companheira de Paulo), ao passo que se ouve em over a voz de Paulo que os circunda de metralhadora nas mãos.

Passamos então para o plano no automóvel do poeta que, junto à Sara, manifesta sua inconformidade pessoal contra a abdicação, contra a recusa da luta armada. O tom pessoal e até mesmo subjetivo de sua revolta manifesta-se quando arremessa seu carro contra uma barreira policial aos gritos de «Eu preciso cantar!». Mortalmente ferido, nos braços de Sara, Paulo começa seu delírio e rememoração dos últimos anos da sua vida. Sozinho nas dunas e ainda de metralhadora em mãos, surge no plano o poema de Mário Faustino «não consegui firmar o nobre pacto entre o cosmo sangrento e a alma pura / Gladiador defunto, mas intacto (tanta violência, mas tanta ternura)». Eis o ensejo para o flashback - delírio que recompõe os últimos anos do poeta até o momento de sua morte, sozinho nas dunas, com a metralhadora apontada para os céus.

Muitos elementos importantes do filme já foram expostos nessas primeiras cenas. Já está claro que o ensejo do relato é um país tropical (o plano por sobre o mar, a praia e a mata tropical) num momento de decisiva crise política, onde cada personagem alegoriza um setor social, os quais compõem as forças em disputa no momento de crise. Vieira é o líder popular mas também populista, político provinciano que oscila entre o apoio de suas bases eleitorais (o povo) e os compromissos políticos com a elite. Sara e os demais militantes à sua volta são a esquerda partidária organizada (no contexto, o Partido Comunista Brasileiro dos anos 1960) que apoiavam Vieira por conta da «função histórica» que ele poderia exercer em 
Eldorado: é conhecida a doutrina «etapista» da esquerda brasileira dos anos 1960, segundo a qual uma democracia burguesa forte e desenvolvimento industrial no Brasil eram etapas necessárias antes de uma futura revolução socialista no país. Já apareceram em cena também o clero (é conhecido o papel de algumas correntes da igreja católica como a Teologia da libertação na resistência ao golpe de 1964 e na denúncia da tortura) e as forças militares federais. A mais complexa dessas personagens e talvez a menos alegórica delas é o protagonista poeta Paulo Martins. É a partir de seu fluxo de consciência agonizante que se constrói o relato, embora também haja no filme elementos que não partem diretamente de sua consciência. Daí o crítico Ismail Xavier ter designado a instância narrativa do filme como «subjetiva indireta livre»: o estado de espírito do poeta dá o tom da narrativa, ele é ao mesmo tempo personagem, narrador e comentador quase onisciente dos fatos, mas a narrativa transcende a subjetividade de Paulo, deixando abertos outros canais de informação_-127.

O poema-epitáfio de Faustino é sugestivo quanto ao conflito que se desenvolve na narrativa: entre cosmo sangrento e alma pura, entre violência e ternura, em suma, entre a interioridade do poeta, sua fome fáustica de absoluto e os horizontes reais que se descortinam num país tropical em crise, ou melhor, «transe». Mas seria mesmo pura a interioridade do poeta? Seria heroica sua atuação? Será de fato ele antagonista das forças opressoras e reacionárias? O filme não deixa de ser um exame da (má) consciência do poeta, e por isso mesmo ele tocou na ferida da intelectualidade de esquerda nacional em 1967, e cinquenta anos depois ainda é capaz de despertar do sono conflitos psicológicos e sociais na consciência brasileira.

A personagem seguinte a entrar em cena é Don Porfírio Diaz, nome emprestado do general mexicano deposto pela revolução mexicana, em 1911. Anunciado pelo poeta como nada menos que «meu Deus da juventude», Diaz surge carregando uma bandeira negra, junto a um conquistador Ibérico do século XV e um padre. A tríade de conquistadores avança pela praia em direção a um índio, numa reencenação da primeira missa no Brasil, e do mito de fundação da pátria. As forças reacionárias do golpe de 1964 surgem assim como que inseridas na dimensão ancestral e mítica do país, a partir da qual momentos de transe e crise como 1964 não passariam de uma repetição quase inevitável. O início da aventura do poeta se dera sob a proteção de Diaz, encarnação do despotismo e da submissão popular «pela força, pelo amor da força» como ele dirá na cena final de sua coroação. Além de Paulo e

\footnotetext{
${ }^{127}$ Ismail Xavier. Alegorias do subdesenvolvimento: Cinema Novo, Tropicalismo e Cinema Marginal. São Paulo: Cosac Naify, 1993.
} 
Diaz, no palácio deste surge Silvia, amante de Paulo, espécie de mulher-objeto cuja beleza está presente em muitas cenas, mas não emite uma única palavra ao longo do filme. Privada da fala, ela é uma espécie de adorno que enfeita a vida dos homens no poder. Silvia é o oposto de Sara, militante, engajada, disciplinada e ativa, que muitas vezes guiou as ações e opiniões de Paulo, e é para ela que ele dirige seu relato agonizante.

A relação entre Paulo e Diaz é um dos principais motores da ação do filme. Diaz é um homem cuja consciência está diretamente alinhada com sua função política: crê-se predestinado ao privilégio do comando e da dominação, traz consigo a cruz, a bandeira negra e a coroa. É uma espécie de figuração de um poder quase medieval, hereditário e inato à dominação. Já Paulo é uma mente em crise, que em tudo vê a marcha trágica para a morte e podridão, mas anseia por algum tipo de ação para desanuviar sua angústia. No palácio de Diaz, Paulo pede para ser liberado de sua proteção, pede como um filho suplica ao pai a liberdade de escolher seus primeiros passos na vida adulta. Diaz não compreende por que seu protegido não estaria satisfeito com suas regalias, seria feito deputado nas próximas eleições e Silvia lhe seria dada como esposa. Também como um pai, vê na atitude de Paulo um radicalismo juvenil.

Paulo Martins vai para a cidade provinciana de Alecrim, onde trabalha em um jornal «independente e noticioso», em que também encontra Sara, que lhe vem mostrar fotos de crianças em situação de miséria. A reação de Paulo é «precisamos de um líder político», e logo se veem Paulo e Sara na casa de Vieira, candidato a governador de Alecrim. O casal torna-se assessor de campanha de Vieira, e descortina-se o teatro eleitoral típico brasileiro. $\mathrm{O}$ candidato sai às ruas abraçando a população, fazendo promessas e anotando demandas. Em especial, vem pedir-lhe ajuda um pobre lavrador, queria ter água para melhorar as suas terras. Uma vez eleito, não demoram para surgir as discrepâncias entre o candidato em campanha e o governador eleito: entre os compromissos com as bases eleitorais e com a elite que lhe dá apoio, Vieira opta pelos últimos, chamando a repressão policial para conter a agitação dos camponeses pobres. A revolta de Paulo contra Vieira, que é a nova figura masculina de poder para a qual ele se põe a serviço, não é livre de contradições e ambiguidades. Bêbado, em confissão à Sara, vemos a imagem do poeta a reprimir os camponeses pobres com as próprias mãos. Vemo-lo provocar e insultar o mesmo lavrador pobre que apareceu na campanha de Vieira. Ainda que ele justifique seu ato como uma provocação, seria isso verdade? Não haveria em Paulo traços de um ranço autoritário e elitista ao estilo de Diaz? Sua figura macabra, de capa preta e braços abertos avança sobre os lavradores. O líder camponês é morto e a população revoltada culpa Paulo e Vieira pelo 
assassinato político. Embriagado e com remorsos, Paulo rompe com Vieira, ao saber que ele optara por continuar ao lado das elites e reprimir os manifestantes.

De volta à capital de Eldorado, vemos Paulo em orgias patrocinadas por Fuentes, empresário oligarca, dono de quase todas as grandes empresas do país. Com Fuentes, surge no filme a representação da burguesia nacional com a qual a esquerda pretendia fazer aliança contra as forças arcaicas do país, contra a exploração estrangeira e o imperialismo. Diferente de Diaz, Fuentes é citadino e cosmopolita, aprecia o Jazz, as festas, as artes, as mulheres, as bebidas. Por meio de Paulo, Sara e os militantes de esquerda procuram persuadir Fuentes a romper com Diaz, seu aliado político, e apoiar a candidatura de Vieira à presidência. Os argumentos de persuasão são de que a empresa estrangeira que atua no país e financiou todas as campanhas de Diaz tinha interesse em destruir seu império empresarial. Já o que convence Paulo a trair seu "Deus da juventude", Diaz, é a possibilidade de voltar para Sara. A campanha publicitária feita por Paulo contra Diaz revela uma trajetória bastante comum de políticos latino-americanos: Diaz havia traído em seu percurso político diversos regimes e presidentes e, com o apoio do capital estrangeiro, apoiara inúmeros golpes e ditaduras. Mas é com sentimento de remorso e culpa que Paulo visita seu antigo protetor Diaz, de onde sai o rompimento final entre os dois e o retorno de Paulo a Alecrim, onde trabalha na campanha de Vieira.

Surge então a cena mais emblemática e debatida de Terra em Transe. «Encontro de um líder com o povo» é o letreiro que introduz a cena, e aos gritos Paulo anuncia: «um candidato popular!». Segue-se então um estranho carnaval. Um bloco de escola de samba faz evoluções no pátio da casa de Vieira, e logo atrás vem o candidato, com seu terno branco, acompanhado de um padre à direita e um político caduco à esquerda. Enquanto o padre profere um discurso em homenagem às missões cristãs na colonização, o político faz uma exortação ao progresso. A farsa desse baile de máscaras sociais, no lugar de onde deveria se apresentar uma alternativa popular e libertadora ante as forças retrógradas de Diaz evidenciase primeiro no mal-estar de Paulo. Ele, enquanto personagem e comentador, circula por entre as personagens alegóricas. A voz de Paulo em over exorta o povo à morte em meio à festa, a morte enquanto força transformadora: «o sentimento do nada que gera o amor, a morte como fé, não como temor». Já ressoa nessas palavras de Paulo a exortação à luta armada das cenas finais, assim como a resistência individual e suicida que ele empreenderá como último gesto de sua vida. Aqui, não existe vislumbre da morte como perspectiva real de transformação e vitória, mas um gesto simbólico, quase ritual de autodestruição num momento de crise. 
Sara, ao observar a turbulência subjetiva de Paulo, convoca Jerônimo para falar. Jerônimo, líder sindical, é designado como o povo, e suas palavras são aguardadas com respeito. Era de esperar que Sara, militante de esquerda, enxergasse no povo o portador de uma nova ordem. A partir da teoria marxista, seriam as mesmas contradições de forças históricas que produziram o proletariado enquanto classe que fariam dele a classe cuja luta é portadora de uma nova ordem, o «salto para a liberdade», o «fim da pré-história da humanidade». Mas as palavras de Jerônimo são tímidas, confusas e servis, limita-se a dizer que o país está em crise, que não sabe o que fazer e que «aguarda as ordens do presidente». Paulo tapa-lhe a boca e, olhando para a câmera diz: «Estão vendo o que é o povo? Um imbecil, um analfabeto, um despolitizado. Já pensaram Jerônimo no poder?». Eis a cena controversa que tocou profundamente Caetano Veloso, a partir da qual ele sentiu-se «liberto» das obrigações do engajamento político e viu a morte do populismo enquanto respeito e esperança nas potencialidades políticas do povo. Mas seriam as palavras de Paulo Martins para serem acatadas assim, literalmente? Ou estaria Glauber Rocha provocando seu público? Ou estaria ele expondo as contradições da inteligência, ela mesma parte da elite opressora, expondo um ranço elitista tabu dos intelectuais? Seja como for, Jerônimo é líder sindical e foi convidado pelos poderosos a falar. Mas um outro povo surge na cena e toma a palavra sem ser convidado. Um povo de roupas rasgadas e miserável toma a palavra e diz: «O povo sou eu, que tenho sete filhos, e não tenho onde morar!». O povo-miséria que toma a palavra sem o aceite dos políticos, dos militantes e da inteligência é duramente repreendido, espancado, enforcado e finalmente morto com um tiro na boca. A miséria não tem lugar no carnaval populista, seja ele de direita ou esquerda. Fora do jogo organizado por aqueles que detêm o poder, o povo se traduz em miséria, em fome, e suas demanda são por demais radicais, "extremistas".

Se não bastasse essa cena para expor as contradições sangrentas e inconciliáveis da estrutura social de Eldorado, a cena seguinte, onde Diaz e Fuentes se encontram, torna isso ainda mais evidente. Diaz vem persuadir o empresário Fuentes a quebrar seu acordo com Vieira e, junto a ele, participar do golpe de Estado que colocará Diaz no poder. Didaticamente explica Diaz a Fuentes: "Escute, imbecil, a luta de classes existe. Qual a sua classe? Como feras famintas eles [o povo] desejarão sempre mais. Eles querem o poder”. Consumada a traição e o golpe, temos a renúncia de Vieira e o fim do flashback. Reencontramos o poeta nos momentos de agonia, e em paralelo se exibe a cena da coroação de Diaz. Esta talvez seja uma das cenas mais carregadas em elementos alegóricos. Novamente, lá está o colonizador ibérico do século XV, o clero, Fuentes, Silvia e uma 
gigantesca coroa. A ascensão de Diaz ao poder possui fortes paralelos com a cena do descobrimento, como se o golpe fosse mais uma etapa do ciclo lá iniciado. Paulo, em delírio, vislumbra o povo faminto invadir a coroação, sua metralhadora abater a todos e a coroa na mão do miserável, mas essa imagem não passa de desejo inalcançável. Com olhar diabólico Diaz vocifera: “Aprenderão, aprenderão! Pela força, pelo amor da força! Pela harmonia infernal dos infernos, chegaremos a uma civilização!".

Fecha-se o ciclo, a agonia, a crise, o transe. A reafirmação da força pela força, do exercício de poder como prerrogativa de uma minoria. Como bem observou Ismail Xavier, a estrutura de Terra em transe é ao mesmo tempo linear e cíclica. O filme tanto retrata um episódio histórico concreto, o golpe de 1964, quanto o inscreve numa estrutura mítica que condena a repetir o ritual macabro em tempos de transe. Afinal, 1964 seria um ano de crise ou transe?

\section{Transe revelador}

Há ao menos duas formas em que o filme de Glauber Rocha influiu sobre aquilo que viria a constituir o tropicalismo, sobretudo no que concerne à pessoa e àss canções de Caetano Veloso. A primeira delas seria o procedimento alegórico como forma de construir a representação: a criação de imagens e personagens que, mesmo tendendo para o absurdo ou irreal, traduzem um conceito a respeito da realidade brasileira que se pretende representar (aprofundaremos isso mais adiante). A segunda, é o aspecto irracional da imagem que se constrói: o país não está em crise, mas sim em transe, as forças em disputas não são apenas históricas, mas inscrevem-se numa temporalidade cíclica, erigindo uma imagem mítica do país. Ou seja, para que ocorra um desvendamento do Brasil, seria necessário ir além das categorias políticas tradicionais, segundo Glauber Rocha: "Não somente a esquerda, mas os partidos liberais não são mais do que uma excrescência europeia num mundo desconhecido, cujas leis eles não conhecem. Meus país é um continente desconhecido" (ROCHA apud RIDENTI, 2014, p. 150, grifos nossos). E foi exatamente como uma revelação de aspectos até então inconscientes que o filme foi apreendido por Caetano Veloso ${ }^{128}$. Justamente esse esforço de ir além das categorias analíticas tradicionais (mesmo que isso desemboque por vezes num misticismo de inspiração sebastianista), na tradução, revelação, ou, para usar uma palavra em voga no tropicalismo, no desrecalcar da realidade nacional, é um traço fundamental do papel que esses artistas reclamaram para si.

128 "E, à medida que o filme seguia em frente, as imagens de grande força que se sucediam confirmavam a impressão de que aspectos inconscientes de nossa realidade estavam à beira de se revelar" Caetano Veloso. Verdade tropical. São Paulo: Companhia das Letras, 1997, p.99. 
Verdade Tropical abre-se com considerações a respeito do Brasil: esse nome sem país, esse lugar nenhum cujo nome arde, esse grande outro da América (o duplo, a sombra, o negativo dos EUA) então prestes a completar cinco séculos de história. O significado desse movimento seria justamente de, pretendendo galgar para si uma posição além da dicotomia política que fendia nação nos anos 1960, desvelar o mistério-Brasil em toda sua complexidade e contradição ${ }^{129}$, nos anos traumáticos dos quais Veloso com plena razão afirma só serem considerados datados e distantes por aqueles que temiam os desafios então surgidos e ainda os temem por saberem-nos por demais presentes (p.19). Mas, antes de prosseguir com a caracterização do tropicalismo e de posições desse movimento deflagradas pelo filme de Glauber Rocha, daremos agora um passo atrás para verificar a recepção da tradição da canção popular brasileira pelos tropicalistas, bem como da dicotomia nacionalestrangeiro.

\section{Santo Amaro global e João Gilberto}

O primeiro capítulo do livro de Veloso descreve a infância na cidade de Santo Amaro, interior da Bahia, anos 1950. Ao contrário do que poderia imaginar tanto o leitor atual quanto os contemporâneos da crônica do autor, a pequena cidade no interior do nordeste, que havia conhecido certa opulência durante o ciclo da cana, mas estava então decadente, não era nem isolada e ignorante da cultura internacional, nem um ambiente puro e intocado da brasilidade, livre dos influxos maléficos do imperialismo cultural. Havia em Santo Amaro os fãs do rock de Elvis Presley, e no cinema, exibiam-se filmes do neorrealismo italiano e demais filmes europeus, além dos americanos. O influxo da cultura global estava presente na província, nem tão ignorante nem tão pura quanto se supunha (mais adiante o autor descreve que as tradições musicais populares lhe haviam chegado pelo intermédio da obra de Edu Lobo, e que ouvintes de Bethânia não aceitavam que ela não cantasse música da "sua terra", sendo que seu repertório de boleros era o que ela de fato ouvia em Santo Amaro). Distinguindo-se da posição dos CPCs diante da cultura internacional (que Veloso viria a conhecer apenas posteriormente, em São Paulo), o autor expõe seu desagrado com o rock não por ser suposto produto alienante do imperialismo cultural, mas pela

\footnotetext{
129 "O que se pretende contar e interpretar neste livro é a aventura de um impulse criativo surgido no seio dos anos 60, em que os protagonistas - entre eles o próprio narrador - queriam poder mover-se além da vinculação automática com as esquerdas, dando conta ao mesmo tempo da revolta visceral contra a abissal desigualdade que fende um povo ainda assim reconhecivelmente uno e encantador, e da fatal participação na realidade urbana universalizante e internacional, tudo isso valendo por um desvelamento do mistério da ilha Brasil". Idem. $\mathrm{p}$. 16 , grifos nossos.
} 
inautenticidade psicológica daqueles que o seguiam. Ou seja, o importante não era a procedência dos modelos culturais, mas sua funcionalidade para a rebeldia. Como situar-se diante da influência americana sem perder a liberdade, inclusive a liberdade de aproveitar um modelo interessante e mais adiantado ${ }^{130}$ ?.

O que o autor procura mostrar, já durante o relato da infância, é que o influxo estrangeiro tanto poderia ser enganador e inautêntico, quanto libertador, a depender da sua articulação com a vida local: Veloso queria ver a vida transformada, mas transformada em Santo Amaro, a partir dela. A cultura popular de massa era potencialmente libertadora, desde que servisse ao desbloqueio da situação local, estagnada pelos conservadorismo, patriarcalismo e desigualdade social.

Longe de ser um anseio pessoal do autor, essa equação entre os problemas sociais da vida local (e nacional), o influxo externo potencialmente libertador, mas também alienante e o trabalho dessa questão nas formas estéticas era vivido candentemente em âmbito nacional. Em Salvador, o recém-inaugurado Museu de Arte Moderna, sob a organização de Lina Bo Bardi, exibia obras do modernismo europeu, além de um acervo crescente de obras brasileiras. O cinema vivia a descoberta da Nouvelle Vague, no teatro se experimentava Brecht, e o maestro e compositor Hans-Joachim Koellreutter apresentava a música dodecafônica e serial. Ao mesmo tempo Miguel Arraes, em Pernambuco, fazia "um governo admirável, em estreita união com as camadas populares; com os CPCs da UNE produzindo peças e canções panfletárias, mas muito vitais (...) o país parecia estar à beira de realizar reformas que transformariam sua face profundamente injusta" (VELOSO, 1997, p.64). Em suma, transformação social, política e cultural, inserida na dialética entre afirmação nacional (popular) e acesso ao cosmopolitismo estava na ordem do dia. Nas palavras de Schwarz, o país estava irreconhecivelmente inteligente.

Mas a figura que sintetiza esse momento feliz de promessa de modernização abrangente, inclusiva e esteticamente bela é, mais uma vez, João Gilberto. Aos 17 anos Veloso ouviu pela primeira vez esses sons "malucos" e "desafinados" (segundo a descrição do amigo que lhe apresentou o disco Chega de Saudade), que, na época, desafiava o gosto conservador. $\mathrm{O}$ impacto é descrito como um processo radical de mudança de estágio cultural, que levou o Brasil a rever suas possibilidades, uma revolução que não apenas abriu o caminho para o desenvolvimento de músicos contemporâneos, como Jobim, mas deu sentido à busca de modernização do samba que vinha sendo empreendida anteriormente. Sobretudo,

${ }^{130}$ Roberto Schwarz Verdade tropical: um percurso de nosso tempo. Martinha versus Lucrécia. São Paulo: Companhia das Letras, p. 52-110, 2012. 
usando a ponta de lança da invenção musical americana (o cool jazz) para melhor religar-se à tradição da canção brasileira, Gilberto "marcou uma posição em face da feitura e fruição de música popular no Brasil que sugeria programas para o futuro e punha o passado em nova perspectiva" (VELOSO, 1997, p.36). Assim, a bossa nova teria nos dado a segurança quanto a nossa capacidade de criar produtos estéticos de grande sutileza e complexidade. Já nas últimas páginas de seu livro o autor se volta mais uma vez para João Gilberto, reafirmando mais uma vez sua importância:

Fique apenas claro aqui que a vereda que leva à verdade tropical passa por minha audição de João Gilberto como redentor da língua portuguesa, como violador da imobilidade social brasileira - da sua desumana e deselegante estratificação -, como desenhador de formas refinadas e escarnecedor das elitizações tolas que apequenam essas formas, (VELOSO, 1997, p.502)

Que o bossanovista seja designado como violador da imobilidade social atesta que o jogo com as formas estéticas não se via de modo algum afastado da interrogação das formas sociais: que o samba do morro, ligado a procedimentos inventivos americanos encontre sua sublimação num produto estético refinado, que subverte o fluxo cultural hegemônico nacional e internacional, além de colocar do Brasil definitivamente no mapa musical mundial, mostra que Gilberto procurava dizer e realizar algo a respeito da estratificação social brasileira. Para Schwarz: "a reviravolta é um micromodelo do alcance total de uma revolução, mesmo restrita" (SCHWARZ, 2012, p.73).

\section{Rupturas (Isto é o povo!)}

Voltemos à cena de Terra em Transe em que o poeta Paulo Martins tapa a boca do líder sindical Jerônimo, humilha-o, xinga-o de imbecil, despolitizado, desqualificando a possibilidade de um poder popular. Cena vista por Veloso como o "núcleo de um grande acontecimento", o qual ele resume como "a morte do populismo". Fosse a morte do populismo em sua acepção correta de manipulação dos interesses populares em nome de um projeto político que perpetua a desigualdade social, não seria de espantar. Mas o que Veloso viu e com o qual se identificou foi a morte da "fé nas forças populares - e o próprio respeito que os melhores sentiam pelos homens do povo - o que aqui era descartado como arma política ou valor ético em si” (VELOSO, 1997, p.105). A cena, que seria um golpe no "populismo de esquerda", abrira-lhe novas perspectivas de natureza "antropológica, mítica, mística, formalista e moral" (Idem), sem a qual o tropicalismo não teria existido. Eis uma 
interpretação um tanto quanto unilateral de uma cena polissêmica e provocadora: Veloso acata sem mais a estúpida violência do ambíguo poeta, alegoria da posição social da intelectualidade de esquerda e do seu papel potencialmente opressor na relação com as forças populares.

Esse evento é sintomático da ruptura que se instaura com o golpe de 1964 (cujo filme procura captar em toda amplitude e profundidade), e da ruptura que o gesto estético do tropicalismo procura assumir. "A desilusão de Paulo Martins transformara-se em desobrigação (...) Se o povo, como antípoda do privilégio, não é portador virtual de uma nova ordem, esta desaparece do horizonte" (SCHWARZ, 2012, p.79). Na interpretação do crítico, a súbita descrença de Veloso nas forças populares é sintomática de um pósmodernismo precoce no Brasil, entendido como momento em que já não há mais um horizonte de superação do capitalismo que pudesse relativizá-lo (Idem). De fato, e ainda acompanhando os argumentos do crítico literário, ocorre na narrativa uma súbita virada: a esquerda, até então criticada, mas estimada, adquire de uma hora para outra um caráter antidemocrático e opressor que não aparecia nos primeiros capítulos. A posição tropicalista (nesse momento ainda em gestação), procurava rechaçar os "embriões de estruturas opressoras" (VELOSO, 1997, p.107) tanto da direita quanto da esquerda - Veloso chega a sentir "estranho júbilo" ao assimilar e concordar com as razões que levaram um colega seu a comemorar o incêndio do prédio da UNE ${ }^{131}$.

Mas qual foi de fato a opressão realizada por essas estruturas? Os dissabores do autor com os membros do CPC e da esquerda, no campo cultural, tiveram início com a sua mudança para São Paulo, em 1965. Sua irmã Maria Bethânia fora chamada para substituir Nara Leão no espetáculo Opinião, dirigido por Augusto Boal. Segundo Veloso, foi irônico que seu primeiro contato com as mentiras do marketing tenha ocorrido com esses homens da esquerda: eles obrigaram Bethânia a alisar os cabelos, e no cartaz do espetáculo diziam que ela era ponta esquerda num time de futebol na Bahia. Considerava então que o nacionalismo daqueles artistas não passava de uma simples reação ao imperialismo, e não genuíno gosto pelas coisas brasileiras nem vontade de propor "soluções originais para os problemas do homem e do mundo", a partir do nosso jeito. Incomodou-o que rechaçassem a hipótese defendida pelos concretistas (com os quais iria em breve se alinhar) de revolucionar pela forma da obra artística. Já em 1967 teria lugar a briga com Geraldo Vandré, o qual tentou convencê-los a não proporem nada de novo no festival pois, pelo bem do Brasil, ele

\footnotetext{
131 "Ele detectava embriões de estruturas opressoras no seio mesmo dos grupos que lutavam contra a opressão, mas nem por isso iria confundir-se com os atuais opressores destes" Caetano Veloso. Verdade tropical. São Paulo: Companhia das Letras, 1997, p. 107
} 
deveria ser a bola da vez, deveria ser a principal atração (haveria ainda o episódio em que Vandré chamou a canção Baby de "merda", acirrando a disputa). Por último, e talvez a mais consequente das disputas, houve a discussão com o jornalista José Ramos Tinhorão, que, em artigos, denunciava a bossa nova e demais correntes inovadoras da MPB como alienantes e antipopulares. Para Veloso, ele era "a defesa articulada do ideário nacional-popular que permeava todos os julgamentos dos esquerdistas brasileiros" (VELOSO, 1997, p.114).

Episódios como esse aguçaram o desejo tropicalista de "destruir o Brasil dos nacionalistas, tínhamos que ir mais fundo e pulverizar a imagem do Brasil carioca (...) tínhamos, por assim dizer, assumido o horror da ditadura como um gesto nosso, um gesto revelador do país"132 (VELOSO, 1997, p.50). Vemos aqui aquela atitude inspirada em Glauber Rocha de "revelar" indo além dos esquemas tradicionais de interpretação, o Brasil em toda sua amplitude, em todas as suas contradições, mesmo naquilo que ele pode ter de horrível, violento e irracional. Mais adiante, no livro, Veloso narra a experiência psicodélica de Gilberto Gil com a Aiuasca, que, sob efeito alucinatório, viu os militares no aeroporto e se sentiu capaz de também amá-los, pois eles também fazem parte do Brasil. Nesse mesmo trecho, que precede o episódio da prisão de ambos os protagonistas do tropicalismo, Veloso considera que a experiência alucinatória e psicodélica (que não apenas eles experimentaram, mas fazia parte do momento de contracultura que chegara ao Brasil em plena ditadura militar), simultânea ao horror do Estado totalitário, é o verdadeiro pano de fundo da tropicália, seu contexto. É nesse clima de contracultura que Veloso mais uma vez delineia suas discordâncias com a cultura política da esquerda, o nacional popular: "eles nunca discutiam temas como sexo e raça, elegância e gosto, amor ou forma. Nesses itens o mundo era aceito tal e qual" (VELOSO, 1997, p.116).

As contradições e inconsistências da "libertação" e "revelação" tropicalista são inúmeras. É o próprio livro de Veloso que fornece muitos elementos contra sua acusação da cultura política da esquerda. Como bem observou Ridenti ${ }^{133}$, suas recriminações ao nacional popular são quase sempre generalizantes e abstratas, sem nomear um artista ou obra que fossem "caretas" ou empobrecedoras. Sobram elogios à figura de Edu Lobo e sua pesquisa formal do folclore brasileiro, elogio mesmo à peça "Arena canta Zumbi”, da qual diz ser a grande responsável pela modernização do teatro brasileiro (sendo o exemplo clássico do nacional popular brasileiro!). O tom é elogioso e reverente, como não poderia deixar de ser,

\footnotetext{
132 Diga-se de passagem, os tropicalistas jamais manifestaram qualquer apoio ou simpatia à ditadura, porém manifestavam um certo apoio, ainda que longínquo à luta armada, à guerrilha urbana.

${ }^{133}$ Marcelo Ridenti. Em busca do povo brasileiro: artistas da revolução, do CPC à era da TV. São Paulo: Editora Unesp, 2014, p.262.
} 
a Vinícius de Morais, apresentado pelo próprio narrador como um dos precursores, junto com Nara Leão (também louvada), da aproximação da bossa nova à arte engajada, cujo resultado foi a criação no Brasil da "forma mais graciosa da canção de protesto do mundo" (VELOSO, 1997, p.72). Seguindo mais uma vez a análise de Schwarz (2012, p.89), a caracterização da esquerda como um bloco maciço e retrógado em estética simplesmente não corresponde à realidade: além dos já citados Vinícius de Morais e Nara Leão, Ferreira Gullar, Sérgio Ricardo, Carlos Lyra, Sérgio Ferro e mesmo integrantes da tropicália como Torquato Neto e Capinan foram artistas ligados ao CPC e realizaram obras que dialogavam com o nacional popular. Ou seja, embora de fato existissem obras simplórias, panfletárias e retrógadas como o disco "O povo canta" lançado pela UNE, em 1961, muito do que se fez de mais ousado em experimentação formal na arte brasileira da segunda metade do século XX mantinha ao menos algum tipo de relação com as propostas do CPC.

Se a acusação estética não procede, haveria alguma consistência na acusação política de opressão? A reação inicial de Veloso diante do golpe de 1964 foi afinada com a avaliação da esquerda: ele seria uma ruptura brusca com o processo de superação da desigualdade social e reafirmação dos interesses hegemônicos dos EUA, ao passo que, antes, o país vivia a sensação de uma modernização abrangente que, como experimentada em Santo Amaro, não negava o que o país tinha de particular, nem era necessariamente opressora aos mais pobres. Ainda assim, o golpe de 1964 e a desobrigação ante o engajamento na luta popular, simbolizado pela cena de Glauber Rocha, emergiram como uma "libertação" para a experimentação formal e comportamental fortemente inspirada na contracultura, então em voga internacional. As palavras "ditadura do proletariado" soavam-lhe mal, não via por que os operários da construção civil ou os da Petrobrás (os quais, na Bahia, já ocupavam uma posição privilegiada dentre os mais pobres) devessem decidir quanto ao futuro da sua vida (VELOSO 1997,p.116). Mais uma vez retomando os argumentos de Schwarz, a alergia de Veloso ao vocabulário marxista tinha ela mesma um viés de classe: para além da ilusão de uma liberdade pessoal incondicionada na sociedade de mercado, será que sua aversão se estenderia aos empresários, banqueiros, donos de gravadoras de estações de tv? Não influenciariam eles a sua liberdade pessoal? O fato é que Veloso, saudando a "morte" da crença nas energias libertadoras do povo, imaginava-se numa posição ao mesmo tempo de ultraesquerda e pró-mercado: ultraesquerda pois desprezava a "caretice" do comunismo ortodoxo e simpatizava com os estudantes do maio de 1968, com Fidel, Guevara e Mariguela, e pró-mercado, pois lutava para contribuir com as "conquistas técnicas e mercadológicas da minha classe" (VELOSO, 1997, p.489), sendo que a própria existência 
de um mercado cultural no Brasil já era vista como uma vitória nacional. "Uma política unívoca, palatável e simples não era o que podia sair daí” (Idem. p.446).

Contudo, todos esses aparentes paradoxos tornam-se inteligíveis quando vistos a partir da posição que Veloso e os tropicalistas tentavam galgar no estrelato musical brasileiro. Nunca é demais reforçar que, nos anos 1960, a canção popular era um assunto tratado com seriedade máxima, ela era o grande veículo na esfera pública brasileira: artigos da época de Julio Medaglia, Augusto de Campos e Homem de Mello testemunham o peso conferido às canções nos festivais, nas quais e pelas quais o embate social velado pela ditadura encontrava uma "rede de recados". Se os tropicalistas quisessem galgar um espaço proeminente no estrelato da MPB, a única opção era contraporem-se à estética do samba e da bossa nova - a qual já tinha sua figura maior e por isso mesmo arquirrival da tropicália: Chico Buarque. A posição de Veloso é perfeitamente inteligível como um esforço para destroná-lo:

\footnotetext{
Ele [Chico Buarque] era a grande unanimidade nacional, o jovem compositorcantor excelente e sedutor, a estrela máxima desse público estudantil que lotava os auditórios dos festivais. Era também o grande sintetizador das conquistas modernizadoras da bossa nova com anseio de volta ao samba tradicional dos anos 30 e de avanço no sentido da crítica social (...) Tudo isso compunha uma imagem preciosa que sua beleza física, sua educação naturalmente elegante, seu gênio pessoal só faziam realçar. Ele encarnava o melhor do melhor da história da música brasileira e era assim que todos o viam. (VELOSO, 1997, p.173-174)
}

Esse retrato, feito por Veloso, resume com muita propriedade a variedade de capitais que a MPB em geral e Chico Buarque em particular acumulavam no final dos anos 1960: jovem e belo, sucesso ao mesmo tempo no público amplo e no público intelectualizado, sucesso de vendas e de engajamento social, popular e ao mesmo tempo sofisticado - ele era síntese do "melhor do melhor" da MPB. A canção Alegria Alegria, que ao lado de Domingo no Parque deflagrou o tropicalismo, foi concebida exatamente como um decalque de $A$ Banda, uma anti-Banda. Na leitura de Augusto de Campos: esta busca o passado e a pureza das bandas e coretos (retratando o poder da canção de trazer alegria efêmera ao povo), enquanto aquela mergulha no presente, com uma linguagem fragmentária, capta o imprevisto da realidade urbana (CAMPOS, 1967). No âmbito estético Alegria Alegria é o posto da canção de Chico, pelo uso de acordes simples (sem pretensão de refinamento harmônico), acompanhada de uma banda de rock e do timbre da guitarra elétrica (do qual sabemos a semântica que isso tinha na época), uma letra não narrativa que "exibia aceitação 
da vida do século XX, mencionando A Coca-Cola" (CAMPOS, 1967, p. 174). Ainda assim, conforme Veloso, ambas se aproximam na métrica e no fato de serem canções de festival, feitas para abrir as portas do sucesso comercial.

Veloso, no mesmo trecho do seu livro, não esconde a intenção de "disputar com ele [Chico] o mesmo lugar no olimpo das estrelas nacionais" (VELOSO, 1997, p. 174). Mas há um outro episódio que demonstra o aspecto relacional da atitude provocadora tropicalista, e da razão de tanta violência simbólica contra os padrões estabelecidos para poder propor essa nova estética urbana, assumidamente cosmopolita e simpática ao universo do consumo e da tecnologia, embora ousada no campo da sexualidade e do comportamento. No final de 1968, Veloso e Gilberto Gil participaram do festival internacional da canção com as canções $E$ proibido proibir e Questão de Ordem: as quais diferentemente de Alegria Alegria e Domingo no parque, foram veementemente vaiadas e desclassificadas, dando ensejo ao famoso discurso-happening de Veloso. Era o momento de auge da provocação tropicalista: Veloso habitava um apartamento no centro de São Paulo decorado com móveis de acrílico, de onde, numa manhã, viu uma passeata estudantil ser dispersada pela brutalidade policial. Ele desceu para ver o que ocorria, de calça jeans, torso nu, sandália, casaco militar europeu antigo e um colar de dentes de animal. Decidiu agressivamente apelar os passantes contra a sua indiferença medrosa, dizendo-lhes desaforos, seguro de que ninguém lhe tocaria um dedo, de que os soldados não o abordariam, pois ia em sentido contrário aos estudantes. Ele se colocava portanto fora do embate direto entre estudantes e militares - e sentindo-se salvo realizava uma performance agressiva para aqueles que queriam apenas passar; "a participação que o profeta [Veloso] incita os passantes não vale para ele próprio" (SCHWARZ, 2012, p.91), calculando que os militares não o veriam como inimigo. Nesse momento, talvez o ponto alto do livro, o cume da atitude tropicalista, declara o autor:

\footnotetext{
Mas nessa estranha descida à rua, eu me sabia um artista realizando uma peça improvisada de teatro político. De, com a licença da palavra, poesia. Eu era o tropicalista, aquele que está livre de amarras políticas tradicionais e por isso pode reagir contra a opressão e a estreiteza com gestos límpidos e criadores. Narciso? Eu me achava nesse momento necessariamente acima de Chico Buarque ou Edu Lobo, de qualquer um dos meus colegas tidos como grandes e profundos. (VELOSO, 1997, p. 319)
}

O significativo episódio concentra muito dos significados do tropicalismo. Um happening afinado com as performances da vanguarda inseria-se obliquamente no vórtice 
do conflito político, mas, embora provocador, calculava friamente as distâncias entre cada um dos polos para manter-se em segurança. Ainda que jogasse com símbolos de amplo alcance (o jeans americano, o casaco militar, o colar de dentes indígena, o torso nu e a cabeleira típicos da libertação sexual contra cultural) os dividendos da performance eram sobretudo subjetivos (narcisistas). Pretendendo estar acima da clivagem política, da opressão da direita e a estreiteza da esquerda, a grande satisfação de fato era considerar-se acima dos colegas de profissão e concorrentes do estrelato. Veloso, que até então possuía uma técnica instrumental apenas rudimentar, podia enfim sentir-se superior ao mestre em harmonização Edu Lobo.

Seja como for, o cálculo subjetivo de Veloso de que estaria à esquerda da esquerda por questionar temas como sexualidade, gosto, forma e beleza, e de que não seria visto como inimigo pelos militares pois saudava a saúde do mercado, revelou-se errado: ele e Gilberto Gil foram presos no final de 1969, depois exilados até 1972. Ainda assim, permaneceu a posição oblíqua tropicalista: embora tenha reafirmado no interrogatório que a sua prisão era injusta, ele não escondeu a irônica satisfação quando o general afirmou que o que ele e Gil faziam era mais perigoso, mais subversivo do que as canções de protesto. $\mathrm{O}$ relato do encarceramento e da brutalidade militar, embora duro, não contempla a dimensão política da opressão, centrando-se muito mais em aspectos subjetivos como a relação do autor com o sono e a ereção, as lágrimas e o sêmen, durante o período no cárcere. Uma vez readmitido ao Brasil pelos militares, Veloso assumiu de vez seu papel como cantor e performance, centrando seu esforço em equiparar o nível do produto musical brasileiro aos padrões ingleses e americanos. Isto talvez seja o que a tropicália tenha de mais inquietante e provocador: ela configurou-se como um imenso esforço de desafiar os padrões estéticos da canção brasileira e sua relação com o engajamento político para possibilitar que seus criadores assumissem o eles são (todos eles, Buarque e Vandré inclusive): criadores de produtos musicais refinados numa sociedade de mercado. Cancionistas que podem ao mesmo tempo intervir e criticar a realidade nacional, inventar formas vanguardistas para a canção, e não precisam envergonhar-se de que "o disco é feito para vender" e de "ganhar muito dinheiro", conforme está provocativamente escrito na capa do álbum Panis et circenses.

\section{Uma arte de invenção brasileira}

Ainda assim, não devemos deixar que a problemática inserção da tropicália no panorama social e político dos anos 1960 nos ceguem para os aspectos propriamente 
estéticos do movimento, que não se esgotam nessa primeira dimensão. $O$ tropicalismo encontrou ampla reverberação no meio intelectual, com cineastas artistas plásticos e críticos alinhando-se às propostas do grupo, ao passo que canções como "Alegria Alegria" gozaram de ampla aceitação popular. Foi seguramente decisivo para o impacto do tropicalismo nos círculos intelectuais a retaguarda crítica que eles receberam dos poetas concretistas, sobretudo Augusto de Campos, que escreveu artigos francamente partidários a favor de Veloso e Gil, reunidos no volume O balanço da bossa e outras bossas.

Já num artigo de 1966, "Da Jovem Guarda a João Gilberto" - portanto anterior à tropicália -, Augusto de Campos começou a preparar o terreno para a defesa de canções que retomassem a inovação formal realizada pela bossa nova. No diagnóstico apresentado, a MPB dos anos 1960 teria estagnado, retomado o paradigma do "sambão quadrado" pré bossa nova, o que seria perceptível no programa da TV Record "O fino da Bossa”, onde Elis Regina, com sua performance maximalista e extrovertida, teria abandonado a sofisticação interpretativa de João Gilberto. Além disso, no mesmo canal de TV (vale lembrar que nessa época a TV era o grande veículo da música popular e a TV Record concentrava todo o "catálogo" das grandes figuras) Erasmo Carlos e Roberto Carlos recriavam no Brasil o pop comercial internacional, para desespero dos nacionalistas da MPB. Estes sentiram (não inteiramente desprovidos de razão) que o imperialismo cultural chegara para disputar espaço na canção brasileira, e reagiram criando a "Frente Ampla da MPB contra o iêiêiê". Na interpretação de Augusto de Campos, ao contrário do que acreditava a frente nacionalista, que para ele havia se convertido numa espécie de "guerra santa", eram os cantores da Jovem Guarda que, com uma interpretação despojada, se aproximavam mais do refinamento de João Gilberto do que os recursos teatrais e dramáticos de Elis Regina e a retórica nacionalizante e folclorizante que rondava a MPB.

Foi nesse contexto que o poeta concretista saudou o aparecimento de Veloso e Gil nos festivais de 1967, os quais, "furando a maré de violas e marias", e recusando a dicotomia entre iêiêiê e a guerra santa contra ele, teriam assimilado a informação moderna dos movimentos de massa da juventude (o pop internacional), captado o imprevisto da vida urbana e traduzindo-o numa linguagem isomórfica, também fragmentária.

Os tropicalistas assim teriam uma atitude antropofágica, deglutiam o que há de novo, sem temer a procedência da informação: Beatles, Jimmi Hendrix, Luis Gonzaga e Vicente Celestino eram assimilados à plêiade da bossa nova. Desse modo, pela assimilação crítica da informação internacional, eles estariam retomando a "linha evolutiva" da canção. Ainda que esteticamente opostos ao que João Gilberto realizou, os tropicalistas aproximavam-se 
dele ao retomar o trabalho sobre o código da canção, a inovação não em termos de temática, mas da própria gramática de sua forma de expressão:

\begin{abstract}
A lição de João é o desafio aos códigos e convenções musicais e a colocação da música popular nacional não em termos de matéria bruta ou matéria prima ("macumba pra turistas", na expressão de Oswald de Andrade) mas como manifestação antropofágica, deglutidora e criadora da inteligência latinoamericana. (CAMPOS, 2012, p. 285)
\end{abstract}

Tratava-se, portanto, de uma estética pautada pela invenção, pela criação de novas formas, que opera diretamente no código, e não apenas no conteúdo ou na matéria prima. Augusto de Campos ampliou o amparo crítico aos tropicalistas ao compará-los com os poetas concretos, sendo Oswald de Andrade o ponto comum entre eles: "a Antropofagia oswaldiana é a própria justificação da Tropicália (Op. Cit. p. 287). Esse ponto comum é o fato das letras tropicalistas valerem-se de uma linguagem não-discursiva, ou seja, com poucos elementos sintáxicos articulando as palavras e/ou sonoridades, prevalecendo o processo de justaposição e de montagem.

O tropicalismo aproximava-se das vanguardas também pelo trabalho em conjunto com músicos eruditos ligados ao grupo da música nova: Julio Medaglia e Rogério Duprat, familiarizados com as técnicas contemporâneas da música serial, eletrônica, concreta, aleatória, etc. Eles trabalharam como arranjadores nos álbuns Panis et Circenses, Gilberto Gil, e Caetano Veloso, num processo que, segundo Gil, foi de criação conjunta das canções ${ }^{134}$. Essa convergência entre música erudita e popular não foi unilateral. Não foram apenas os tropicalistas que se valeram do status e da competência dos eruditos, mas a própria música erudita de vanguarda internacional já caminhava em direção aos aspectos do cotidiano e de uma experiência fragmentária. Essa aproximação entre o músico "de laboratório", ou seja, o pesquisador profissional de novas formas de expressão, e do músico inserido na esfera do consumo cultural, Augusto de Campos apelidou de "produssumo", pesquisa, produção e consumo sendo pensados conjuntamente. Não por acaso essa admissão do fator consumo provocou frisson entre intelectuais de esquerda como Roberto Schwarz: admitir que "o disco foi feito para vender", de que Elis, Chico Buarque e Veloso eram, dentre

\footnotetext{
134 "Nós nos sentamos, durante 4 ou 5 dias, em tardes consecutivas, e fomos discutindo, formulamos, reformulamos e até no estúdio ainda fizemos modificações em função das sonoridades que resultavam, Foi realmente um trabalho em conjunto". Duprat Apud Augusto de Campos (org.). Balanço da bossa e outras bossas. 5a ed. São Paulo: Perspectiva, 2012
} 
outras coisas, vendedores de discos, foi um dos tabus com os quais a tropicália provocou a cultura política dos anos 1960 .

Mas devemos retomar ainda o contato dos tropicalistas com a antropofagia, pois é aí que reside o sumo da visão que esses cancionistas lançaram sobre a ideia de uma modernidade brasileira. Tanto Veloso, Gil, e Campos associaram o trabalho dos tropicalistas com a antropofagia de Oswald Andrade quanto críticos externos ao movimento os aproximaram desse momento da cultura brasileira, o qual também propunha uma visão sobre a modernidade nacional, mas com diferenças fundamentais, que devem ser ressaltadas. Os tropicalistas valeram-se da antropofagia como modelo para a articulação do local com o global, a cultura brasileira e a mundial, mas também como modo de articular o arcaico e o moderno: o berimbau e a guitarra elétrica, o monumento e a criança feia e morta, a bossa e a palhoça, batman e macumba. Mas como se daria essa articulação entre local/global, arcaico e moderno em Oswald de Andrade, sobretudo no âmbito do Manifesto Antropófago?

Seguindo a interpretação de Beatriz Azevedo ${ }^{135}$, o Manifesto de Oswald de Andrade pretendia manifestar, trazer à tona, desvelar, desrecalcar a concepção antropofágica: uma articulação entre eu e outro, identidade e alteridade feita pelo estômago, na chave do lúdico: a "antropofagia nos une", social, economica e filosoficamente. Mas esse unir-se não trata de assimilar o outro ou mimetizá-lo, mas por meio dele transformar o próprio eu em outro, auto transfigurar-se com a ajuda do contrário. "Só me interessa o que não é meu. Lei do homem. Lei do antropófago"136 diz o quinto aforismo, mas um interesse pelo outro livre de "todas as catequeses" (quarto aforismo). O índio nu, polígamo e ocioso, que ignorava a gramática ("nunca tivemos gramáticas", nono aforisma), que nunca admitiu o nascimento da lógica, que fez Cristo nascer na Bahia, que nunca admitiu um "espírito sem corpo". Este ser, portador de uma cultura matriarcal e lúdica, nos ajudaria a superar a cultura patriarcal, messiânica e autoritária, aliando-se à técnica: "já tínhamos o comunismo" (25) e "antes dos portugueses descobrirem o Brasil, o Brasil tinha descoberto a felicidade" deveria aliar-se à técnica "A fixação do progresso por meio de catálogos de televisão. Só a maquinaria". O "bárbaro tecnicizado" de Oswald de Andrade era a sugestão de uma apropriação subversiva do progresso técnico em nome de uma sociedade antiautoritária, desrecalcada, matriarcal e lúdica: contra a imagem do pai, dos sistemas lógicos, da catequese, da gramática, da ordem.

Embora haja pontos de contato entre a antropofagia oswaldiana e o tropicalismo, mesmo em aspectos formais de construção do texto, há uma diferença importante. A

\footnotetext{
135 Beatriz Azevedo. Antropofagia: palimpsesto selvagem. SÃO PAULO: Cosac-Naify, 2016.

136 Manifesto Antropófago 1928.
} 
articulação do arcaico e do moderno, no tropicalismo, não surge em razão de uma perspectiva utópica, libertadora. Surgiu da percepção da permanência insistente de elementos arcaicos sumamente negativos como a miséria, a desigualdade, a autoridade patriarcal reacionária, no seio de uma sociedade que se tentava modernizar. $\mathrm{O}$ arcaico aqui não é o índio nu, livre e comunista, mas a criança feia e morta, miserável, o autoritarismo reacionário deflagrado pelo golpe de 1964: mais uma vez, a cena do conquistador ibérico, do padre e do político reacionário em Terra em Transe, forças arcaicas inscritas na esfera mítica do país. Daí a pertinente leitura de Robert Schwarz, no artigo Cultura e Política, de 1969: em oposição à cultura política da esquerda, para a qual os males do subdesenvolvimento seriam passíveis de superação (por exemplo o método Paulo Freire que propunha superar o analfabetismo e politizar as classes populares), na alegoria tropicalista os males do subdesenvolvimento figuram como insuperáveis, numa justaposição aberrante. O tropicalismo registra, valendo-se de recursos e técnicas da vanguarda e da moda internacionais, com seus pressupostos econômicos, o atraso do país como coisa aberrante, mas inscrita na alma nacional. Ele cristaliza a imagem do Brasil em 1964 e reafirma o fato de que, nos países subdesenvolvidos, a integração ao novo se faz estruturalmente mediante o atraso social, que se reproduz em lugar de extinguir. Nesse modo de ver, o conjunto da América Latina é tropicalista (SCHWARZ, Op. Cit).

Favaretto, por sua vez, argumenta que as alegorias tropicalistas funcionam como uma experiência alucinatória do mundo patriarcal, mas que apresentaria o Brasil não como uma fatalidade, mas sim como um país que ainda não chegou a ser. Ainda assim, isso se articula com o ponto de Schwarz no sentido de que o Brasil, enquanto de algum modo não realizar as suas potencialidades, está como que fadado ao kitsch arcaico-moderno. Já o país que ainda não veio a ser configura-se como um ideal sebastianista - como admitido pelo próprio Caetano, inspirado por Glauber Rocha (VELOSO, 1997, p.340) - um país que seria uma "solução nova e original para os problemas do homem e do mundo" graças a um "jeito nosso" especial, único, um não sei que gracioso que um dia fará do Brasil a terra utópica de um mundo melhor e experimental. Segundo Schwarz, com toda razão, essa é uma visão regressiva: abdica da história e recai em remotos misticismos nacionalistas ${ }^{137}$.

\footnotetext{
${ }^{137}$ Eis um exemplo retirado de uma recente crônica de Caetano, apenas um entre tantos, a respeito de suas crenças num "destino" grandioso para o Brasil, de inegável inspiração sebastianista : "Desistir do Brasil, não desisto. Gosto dele como Dostoiévski gostava da Rússia. Mas, sendo o Brasil o que é e eu quem sou, com mais alegria. Com sonhos de tornarmo-nos caminho de luz para todos os povos, brecha aberta para passagem ao Quinto Império. Sim, Império" Caetano Veloso: Revisão muito incompleta do ano de 2018. Folha de São Paulo. São Paulo, 25 dez. $2018 . \quad$ Disponível $<$ https:/www1.folha.uol.com.br/ilustrissima/2018/12/caetano-veloso-revisao-muito-incompleta-do-ano-de2018.shtml>. Acesso em: 03 maio 2019.
} 


\section{Capítulo IX: Crise e Clara}

Se anteriormente dissemos que o álbum Clara Crocodilo nos serviria como sonda para mergulhar em momentos anteriores da canção brasileira, agora podemos dizer, mais corretamente, que esse álbum pode ser compreendido como um palimpsesto: texto escrito sobre camadas e mais camadas de escritas anteriores. Mesmo não pertencendo a nenhum panteão das grandes obras nacionais ${ }^{138}$, este álbum, esquecido e empoeirado nos sebos, concentra um grande volume de informações a respeito da canção brasileira e da dinâmica política e cultural na qual ela está inserida. Uma vez traçado o panorama de momentos chave da canção, podemos divisar agora algumas das principais linhas de força que se insinuam no álbum de Barnabé e interpretar o significado delas na dinâmica cultural da canção.

\section{A representação do popular:}

Nas canções de Clara Crocodilo temos a representação de espaços de prostituição, jogos noturnos, cemitérios, bares, espaços habitados por figuras igualmente afastadas das categorias de status mais elevadas: a prostituta, o cliente, o cafetão, o bêbado, a viúva que vai da luz à sombra com o desespero da morte do marido. Personagens e espaços sombrios, ocultados, habitados por párias. Embora esses personagens pertençam aos grupos de status mais baixos, é nas duas canções finais que surgem, de maneira inequívoca, figuras populares. O motoboy transformado em monstro-marginal-facínora e sua ex-namorada Perpétua são figuras do trabalhador pobre. Se ela, antes caixa de supermercado (uma existência transformada em apêndice da máquina no processo de produção) logra ascender socialmente ao ceder sua imagem e seu apelo sexual para as sedutoras e traiçoeiras imagens eletrônicas (a vida a mentir), Durango transforma-se em monstro, vítima e por fim, carrasco. Como já foi notado por Nazário e Garcia, o monstro Clara Crocodilo alude ao processo de exclusão e de violência urbana. "Clara" é o outro, a potência sempre perigosa e ameaçadora presente nas classes populares.

Vimos que nas décadas de 1920 e 1930, no próprio termo favela ressoa o juízo negativo do povo visto como o outro, o inculto, degenerado e ameaçador - como a população dizimada na guerra de Canudos. Mas também era desse outro que dependia o projeto de construção de um país moderno, foi da sua presença nos modernos meios de difusão sonora

\footnotetext{
${ }^{138} \mathrm{Ou}$, como formulou Georg Simmel: "de qualquer ponto na superfície da existência, por mais que ele pareça brotar apenas nessa superfície e a partir dela, se pode sondar a profundidade da alma”. Georg Simmel. As grandes cidades e a vida do espírito. (1903). Mana, Rio de Janeiro, v. 11, n. 2,p. 577-591, Out. 2005.
} 
que emergiu o símbolo de brasilidade por excelência (o samba), temido por setores de elite como expressão inculta e incivilizada de um povo que precisaria ser educado por uma música de ethos cívico. Essa contradição entre o povo enquanto potência criadora de uma nação vindoura (e a ideia de modernidade, nos países latino-americanos, no início do século XX, esteve mais associada à utopia temporal de um futuro redentor do que à percepção de uma crise) e o povo enquanto repositório do atraso, vulgaridade e destruição é uma clivagem das mais importantes na dinâmica política da canção. A partir dessa contradição fundamental, podemos compreender a disputa entre Noel Rosa com seu "feitiço decente" e Wilson Batista com seu "orgulho em ser tão vadio" como algo muito maior do que uma disputa pessoal e anedótica. Mas sim uma disputa, no âmbito da prática de representação mais disseminada na cultura brasileira, pelos sentidos associados ao popular e o lugar social do samba. $\mathrm{Na}$ dialética da malandragem-samba, ora o acento recaía sobre a assimilação (ainda que carnavalizante) à totalidade e à ordem, ora na sua negação e afirmação de um ethos desafiador.

É a partir dessa mesma contradição que se compreende como pôde a inovação formal de João Gilberto ser considerada um desafio à "nossa deselegante desigualdade social": mostrar que o samba pode ser alçado ao refinamento formal das mais inventivas formas internacionais jamais deixará de ser uma afronta à segregação, assim como um micro modelo de uma revolução social, como percebeu Roberto Schwarz. Essa mesma contradição aparece com força na proposta política do nacional popular do CPC, embora seja surpreendente a visão sumamente negativa da arte popular no Manifesto do $C P C$, a qual só poderia ser redimida quando transformada em instrumento pedagógico. Não deixa de ser surpreendente também que criadores ligados ao CPC, como Lyra, Sergio Ricardo e Vinícius de Morais, concretizaram um imaginário nacional popular na canção brasileira à revelia das propostas do manifesto, conquistando frações intelectualizadas do público.

A personagem criada por Barnabé manifesta a mesma "morte" da esperança nas classes populares assumida pelos tropicalistas. Há nela o mesmo gozo ambíguo da cultura popular como manifestação algo grotesca e kitsch do "Brasil profundo". Se Veloso interpretou em seu álbum de 1967 o dramalhão sentimental de "Coração Materno" de Vicente Celestino, Barnabé faz ecoar os versos de Orestes Barbosa como imagem espectral a assombrar o jovem bêbado e sexualmente frustrado num balcão de bar: indicações de que esses artistas se reapropriavam de linhas longínquas da canção. Nesse aspecto, Barnabé radicaliza o estranhamento e o desconcerto manifestado já na tropicália com o popular, intensificando também o potencial ameaçador e destrutivo dessa figura. Tal figuração do 
povo, em ambos os momentos, não são aleatórias, mas articulam processos sociais e políticos com os quais se defrontavam: a situação da esquerda pós golpe de 1964 e o recrudescimento da violência urbana na crise pós milagre econômico.

É preciso salientar também a diferença fundamental entre tropicália e Barnabé na representação do popular. A "morte do populismo" não significou, para Veloso, o distanciamento puro e simples das esperanças associadas à modernidade nacional, mas sim, em suas palavras, na "abertura de novas perspectivas" (VELOSO, 1997, p. 105). No lugar da cultura popular como pedagogia política, Veloso por vezes opta por uma representação que capta a vivência da pobreza, como em Paisagem útil (Domingo no Parque de Gilberto Gil também pode ser compreendida nessa chave). Em Arrigo Barnabé percebe-se um distanciamento muito maior, na representação do popular e das esperanças a ele associadas numa visão da modernidade. Distância estilisticamente construída pela ironia e pela estética kitsch. Não por acaso, nas duas canções que abordam diretamente figuras populares, a construção da cena apela para recursos ficcionais que desconstroem a verossimilhança, beirando mesmo o absurdo e o deboche. Recursos que distanciam o envolvimento emocional do ouvinte. Ao lidar com a representação do popular, a estética de Barnabé é ambígua e ironicamente distanciada.

\section{Crise da aspiração modernizante como superação do subdesenvolvimento:}

A articulação de imagens, ideias e aspirações em relação à modernidade nacional é uma outra linha de força que atravessa a história da canção em todas as suas fases, sendo um ponto de especial interesse no álbum Clara Crocodilo. Nas décadas formadoras da linguagem cancional brasileira, embora a temática da modernização mostre-se de modo mais oblíquo que em momentos posteriores, devemos notar que o problema da identidade e do popular (em sua contradição) estavam intimamente atrelados ao projeto de se construir uma nação. Isso está bem exposto na discussão de Wisnik a respeito do projeto musicalpedagógico de Villa-Lobos e Mário de Andrade. Deve-se notar também que a linguagem cancional surge da introdução das tecnologias de reprodução sonora e ainda hoje é especialmente permeável a todo tipo de influência tecnológica e estética do momento. Não por acaso a primeira canção gravada no Brasil, "Pelo Telefone", remete às novas tecnologias de comunicação e se apresenta como um "recado" telefônico. Técnica, popular e modernidade estiveram, na história da canção, sempre entrelaçados.

Mas é com a bossa nova que a modernidade passa a ocupar o centro das preocupações da canção, em diversos níveis e num amplo espectro de conotações. Podemos dizer que a 
preocupação central da estética da bossa nova foi criar uma canção inequivocamente brasileira, a qual formaliza materiais populares transformando-os em um artefato estético moderno. Uma canção de "exportação", complexa, insinuando possibilidades de o Brasil superar sua posição subdesenvolvida e dependente. Ela oferece imagens de uma modernidade leve e sofisticada, onde as contradições entre o local e o universal, o popular e o refinado estão senão superadas, ao menos equilibradas na leveza.

Em Clara Crocodilo percebe-se a mesma ambição de criar canções que sejam um artefato moderno, atualizado perante as tendências eruditas e pop internacionais, mas fazendo-o no polo oposto à bossa nova. No álbum, as referências às formas da canção nacional estão muito mais distantes, fazendo-se presente em primeiro plano as influências da cultura pop internacional: os quadrinhos, o cinema, a ficção científica. As intertextualidades com a canção nacional ocorrem mais no plano do conteúdo do que no plano da forma. Ainda assim, a absorção tanto do pop internacional quanto da canção brasileira recebe um tratamento distanciado pela ironia e pelo kitsch. Já as técnicas de composição da segunda escola de Viena, apropriadas com todo respeito, não são mobilizadas para apontar caminhos utópicos de uma modernidade acolhedora, mas sim para criar, na esdrúxula conjunção de melodia temática, aceleração e dissonância, um retrato caricatural de uma modernidade desumana, monstruosa, sombria. Qualquer noção de síntese e equilíbrio são aqui afastadas.

Se é evidente que Barnabé recupera muito do que fora proposto pela tropicália, suas canções estão desprovidas da alegria carnavalizante do jogo com as formas pop e populares, assim como o influxo estrangeiro não exerce uma influência libertadora ou contestadora, categorias caras à tropicália. Apaga-se aqui a esperança de uma modernidade nacional positiva - nem mesmo a esperança mítica da tropicália subsiste -, restando apenas o gozo ambivalente na exaltação da dissonância, a volúpia pelo desprezível, a atração pelo repulsivo, o abjeto transformado em objeto. Uma imagem em perfeita consonância com o poema de Baudelaire citado - erroneamente - por Barnabé nos últimos versos da canção, do qual selecionamos a seguinte estrofe ${ }^{139}$, especialmente explícita de uma experiência do moderno como o gozo (sempre fugaz e transitório) do pútrido:

Assim como um voraz devasso beija e suga

O seio murcho que lhe oferta uma vadia,

\footnotetext{
139 Trata-se dos versos da canção "Clara Crocodilo": "Até seu coração...ouvinte meu, meu Irmão", que se referem aos seguintes versos do poema de abertura das Flores do Mal: "Hipócrita leitor, meu igual, meu irmão!”
} 
Furtamos ao acaso uma carícia esguia

Para espremê-la qual laranja que se enruga

É certo que a volúpia pelo desprezível é algo inerente à tropicália: “Zé Celso gostava de dizer que havia um forte componente masoquista no tropicalismo. De fato, havia como que uma volúpia pelo antes considerado desprezível” (VELOSO, 1997, p. 256). Mas nela, ainda havia a esperança de que essas "heresias" estivessem "organicamente vinculadas à regeneração do ambiente da música popular no Brasil” (Idem). Masoquismo ligado não apenas à esperança de regeneração musical, mas ligado à pretensão, de inspiração oswaldiana de "superar o messianismo patriarcal", superar os elementos "caretas", disciplinadores e conservadores presentes até mesmo na estética e na política nacional popular do CPC. Um mergulho no inferno com intenções de choque revelador e "desrecalcante" - ou, como formulou Roberto Schwarz, provocar a sensação de que segredos de família foram expostos à luz do dia. Mesmo essa função terapêutica do abjeto parece distante das canções de Barnabé, restando do choque com a dissonância pouco mais do que o habituar-se com o sabor do gosto amargo do futuro. Não há horizonte de superação e a única figura a desestabilizar tal estado de coisas é ela também terrível e ameaçadora. Se Antonio Candido celebrou o fato de o samba vencer barreiras de classe, se Veloso saúda Gilberto como violador da desigualdade social e se o tropicalismo se pretendia violador de todas as estruturas opressoras, quebra, violação e destruição é tudo o que resta na imagem de São Paulo feita por Barnabé, sem que qualquer modernização como esperança de superação esteja no horizonte.

\section{Crise da posição da MPB na esfera pública e na indústria cultural:}

Mas a modernização claustrofóbica desse álbum também aponta para outra questão: a problemática posição ocupada por Barnabé e seus colegas da Vanguarda Paulista no campo musical, assim como do próprio nicho da canção que dialoga diretamente com as posições apresentadas ao longo dos últimos capítulos. Como já foi notado mais de uma vez ao longo deste trabalho, o monstro marginal de Barnabé é também (mas em hipótese alguma somente) uma alegoria da própria canção: uma morta-viva aprisionada em discos fora dos grandes circuitos de circulação - uma prática musical que permaneceu restrita a um nicho específico de ouvintes e desconhecida do grande público.

O trabalho de Dias (2000) expõe em detalhes o processo de reestruturação da indústria cultural brasileira nos anos 1980, um processo de desterritorialização e concentração de poder em escala global, os quais, aliados à forte recessão econômica pós-milagre, resultou 
num ambiente muito mais restrito para a construção de novas carreiras e novas propostas musicais. É preciso lembrar que, em momentos anteriores, todos os artistas que "marcaram época" na canção haviam encontrado apoio nas estruturas das grandes gravadoras (ou, como foi o caso nos anos 1960, a canção era o grande atrativo dos programas televisivos líderes de audiência). Os artistas da Vanguarda Paulista também aspiravam ao amplo sucesso, mas permaneceram em um público restrito.

Conforme procuramos apresentar no primeiro capítulo, a narrativa segundo a qual os artistas da Vanguarda Paulista não obtiveram o sucesso e o reconhecimento por haverem sido marginalizados pelas grandes gravadoras não se sustenta. Todos receberam, em algum momento de sua carreira, um contrato de gravação com uma das "majors", ainda que por tempo limitado e sem grande auxílio para o marketing e distribuição. Ou seja, o sucesso amplo não ocorreu por uma série de motivos, muito mais complexos que a simples vitimização desses artistas. Ainda assim, é inegável que nos anos 1980 ocorreu uma reorganização na indústria musical brasileira que, se, por um lado, produziu sucessos de massa como o Axé, a Lambada, o Sertanejo etc., passou a ser mais restritiva no apoio a propostas que dialogavam com as questões culturais e políticas nas quais a MPB esteve engajada ao longo de décadas. Sem entrar em juízos de valor contra vertentes da canção hoje desprezadas como lixo cultural, exatamente como o samba nas primeiras décadas do século XX, é inegável que a reorganização da indústria musical orientou-se para a produção de sucessos de massa, ao passo que a produção engajada na problemática política e cultural da MPB deu-se majoritariamente fora do circuito das gravadoras.

Contudo, se em momentos como a bossa nova, na canção engajada do CPC e mesmo na tropicália veem-se esforços para criar um discurso que articule a nação em sua totalidade, na Vanguarda Paulista não há a ambição - ou até mesmo a possibilidade - de criação desse discurso: uma imagem-choque-desvendamento do Brasil não surge aqui, mas sim um discurso muito mais fragmentário a respeito da cidade e da modernidade nela experimentada. Isso se articula também com o fato de que, já no governo Figueiredo, a ação política não estava mais restrita ao âmbito cultural, como no período pós 1968, sendo articulada diretamente em movimentos sociais e partidos como o então recém fundado PT. Com a retomada do voto e da participação política, aliada a um circuito cada vez mais fechado das gravadoras, a MPB perdeu parte do impulso que fez dela, nas décadas anteriores, um lócus privilegiado para a articulação de discursos na esfera pública brasileira. 


\section{Crise da MPB oriunda de setores da classe média como articuladora de um discurso totalizante a respeito da sociedade brasileira:}

Uma canção morta-viva num disco empoeirado, representação irônica, kitsch e distanciada da marginalidade, da desigualdade e violência urbana; a figura do povo, na qual outrora se via a "qualidade de heróis da futura guerra de libertação nacional" transformada em monstro: não faltam elementos indicativos de que, no álbum em questão, se está diante de uma crise social, política e cultural. Mas gostaríamos de adicionar mais uma dimensão da crise que se articula nesse discurso: a crise de um radicalismo de classe média como articulador de um discurso totalizante a respeito da sociedade brasileira. Marcelo Ridenti recupera o conceito de Antonio Candido sobre o radicalismo de classe média, ao discutir as posições políticas do nacional popular e do tropicalismo na década de 1960: um pensamento que, passando por cima das cisões de classe, pensa os problemas na escala da nação e preconiza soluções para ela em seu conjunto (RIDENTI, 2014, p. 268) Ou seja, trata-se de um discurso que frequentemente elude as questões de classe em nome de visões unificadoras e totalizantes da nação (lembre-se que Veloso constrói uma linha que vai dos sambas do recôncavo baiano, passando por Caymmi, até João Gilberto como modelador do "estilo brasileiro nuclear").

No panorama que traçamos, especialmente a partir da bossa nova, é inegável que artistas oriundos de setores da classe média reclamaram para si uma posição de destaque no campo cultural e articularam discursos - por vezes utópicos, críticos, engajados e até mesmo distópicos - do Brasil, sua modernização e o papel do povo nesse processo. Nas palavras de Ridenti: "Essa indefinição de classe e a utopia da brasilidade como portadora de uma nova civilização seriam marcas da vivência, da produção artística e do pensamento social brasileiro dos anos 1960, produzido pela intelectualidade emergente e engajada de classe média, buscando sua própria representação política como classe” (RIDENTI, 2014, p.270). Um aspecto essencial da crise que se articula em Clara Crocodilo é a dificuldade cada vez maior de um nicho da canção, enquanto prática cultural oriunda de estratos da classe média, de falar em nome do povo elaborar visões para o Brasil como um todo. Clara não apenas sofre as consequências da fragmentação do campo musical, como também pressente o Negro Drama: na década de 1990 surgirão artistas das classes mais baixas, que, sobretudo no rap, articularão discursos sobre violência, racismo, exclusão como testemunhas dos seus próprios relatos. Os "intérpretes esclarecidos do povo", como se pretendiam os artistas do CPC, são aqui dispensados: a "voz do povo" deixa de ser uma figura de expressão ou mero slogan político. A ambivalência do popular dá lugar à luta deflagrada, retratos de uma guerra 
cotidiana com cor, gênero e classe. Por sua vez, nas primeiras décadas do século XXI o panorama musical, por um lado, fragmenta-se ainda mais com as tecnologias digitais de reprodução e circulação musical que põem em crise as grandes gravadoras; por outro, abrese para uma gama de pautas identitárias ((homo)sexualidade, (trans)gênero e periferias) que tornam impensável a voz do povo como uma única voz.

\section{Conclusão}

Afinal de contas, o objetivo pode ser definido como um esforço para dar concretude à frase de José Miguel Wisnik: "a canção popular soletra em seu próprio corpo as linhas da cultura, numa rede complexa que envolve a tradição rural e a vanguarda, o erudito e o popular, o nacional e o estrangeiro, o artesanato e a indústria" (WISNIK, 2014, p.210). Assim fizemos no exercício de destrinchar as linhas de forças sócio históricas a partir de um "ponto da superfície" da canção. Mas em vez da metáfora do "soletrar", adotamos aqui o conceito de articulação, justamente para nos afastarmos da visão das formas culturais como mero reflexo das formas sociais e econômicas. A ideia de articulação procura reforçar justamente o aspecto ativo da prática de representação, não simplesmente um reflexo fiel, mas um esforço produtivo de atribuição de sentido. O especial interesse pelas formas culturais, "lúdicas", como a canção, é a capacidade de suas formas de persuasão de insinuarse no e pelo corpo: um corpo perceptível, sensível, desejante. Se Walter Benjamin reconhece no cinema a introdução da máquina nos nervos do homem, as máquinas de reprodução sonora que fizeram surgir a moderna canção fazem pulsar no corpo representações mergulhadas em conflitos e contradições históricas. 


\section{Bibliografia:}

ADORNO, Theodor; Horkheimer, Max. Dialética do Esclarecimento. São Paulo: Jorge Zahar Editor, 1985.

ALMEIDA, Jorge; BADER, Wolfgang (orgs). Pensamento Alemão no século XX. Vol. III. São Paulo: COSAC NAIFY, 2013.

ANDRADE, Mário de. Ensaio sobre música brasileira. S. Paulo: Martins, 1962.

ANDRADE, Mario de. Aspectos da música brasileira. Belo Horizonte/ Rio de Janeiro: Villa Rica, 1991.

ANDRADE, Mário de. Pequena história da música. São Paulo: Livraria Martins, 1967.

Arte em Revista - Independentes, Ano 6, número 8, São Paulo: CEAC/ECA, 1984.

AUSLANDER, Philip. Performance Analysis and Popular Music: A Manifesto. Contemporary Theatre Review, Vol. 14(1), 2004,

AUSLANDER, Philip. Musical persona : the physical performance of popular music. In: SCOTT, Derek. The Ashgate research companion to popular musicology. Ashgate Publishing, 2009.

AZEVEDO, Beatriz. Antropofagia: palimpsesto selvagem. SÃO PAULO: Cosac-Naify, 2016.

BARCELLOS, Jalusa. CPC da UNE: uma história de paixão e consciência. Rio de Janeiro, Nova Fronteira: 1994. Anexo, p. 441 a 456.

BASTOS, Maria. Processos de composição e expressão na obra de Itamar Assumpção. 2012. Dissertação de Mestrado - Universidade de São Paulo. Escola de Comunicação e Artes. Departamento de Música.

BATISTA, Juliana. O universo de Clara Crocodilo: História e música no LP de Arrigo Barnabé. 2013. Dissertação de Mestrado - Pontifícia Universidade Católica do Rio Grande do Sul. Faculdade de Filosofia e Ciências Humanas. Programa de Pós-Graduação em História.

BAXANDALL, Michael. L'oeil du Quattrocento: l'usage de la peinture dans l'Italie de la Renaissance. Paris: Gallimard, 1985.

BECKER, Howard S. Les mondes de l'art. Paris: Flamarion, 1988.

BRIGUET, Paulo. O que compõe Arrigo Barnabé. Entrevista de Arrigo Barnabé ao Jornal de Londrina (online), 20 de julho de 2010.

BORGARDS, Roland. Texte zur Kulturtheorie und Kulturwissenschaft. Stuttgart: Reclam, 2010.

BOURDIEU, Pierre. A distinção: crítica social do julgamento. São Paulo: Edusp, 2007. 
BOURDIEU, Pierre. A produção da crença: contribuição para uma economia dos bens simbólicos. Porto Alegre: Zouk, 2006.

BOURDIEU, Pierre. Les règles de l'art. Paris: Éditions du Seuil, 1992.

BOURDIEU, Pierre. Questions de Sociologie. Paris: Les Éditions Minuit, 1984.

BUARQUE de HOLANDA, Heloísa. Impressões de viagem: CPC, vanguarda e desbunde. Rio de Janeiro: Rocco, 1980.

BÜRGER, Peter. Teoria da Vanguarda. São Paulo: Cosac Naify, 2012.

CAMPOS, Augusto de (org.). Balanço da bossa e outras bossas. 5a ed. São Paulo:

Perspectiva, 1993.

CANDIDO, Antonio. O discurso e a cidade. São Paulo: Duas cidades, 1993.

CANDIDO, Antonio. A revolução de 1930 e a cultura. Novos estudos CEBRAP, v. 2, n. 4, p. 27-32, 1984.

CASTRO, Riba de. Lira Paulistana: um delírio de porão. São Paulo: Editora do Autor, 2014.

CAVAZOTTI, André. O serialismo e o atonalismo livre aportam na MPB: as canções do LP Clara Crocodilo de Arrigo Barnabé. IN: Per Musi On line - Revista Acadêmica de Música. BeloHorizonte.V.1,2000.

CAVAZOTTI, André. Processos seriais na música de Arrigo Barnabé: As oito canções do LP “Clara Crocodilo”. 1993. Dissertação (Mestrado em Música) - Universidade Federal do Rio Grande do Sul. Instituto de Artes. Curso de Pós-Graduação em Música, Porto Alegre.

CERQUEIRA, Beatriz Lopes Jardim. Você já viu aquela menina que tem um balanço diferente? A vanguarda musical paulista dos anos 1980. 2005. Dissertação de Mestrado - Universidade de São Paulo. Faculdade de Filosofia, Letras e Ciências Humanas.

Departamento de História.

CHAGAS, Luiz; TarantIno, Mônica. Pretobrás: Por que Eu Não Pensei Nisso Antes? vol. 1. São Paulo, ediouro, 2006a.

CHAUÍ, Marilena. O nacional e o popular na cultura brasileira: Seminários. São Paulo: Brasiliense, 1983.

CONTIER, Arnaldo Daraya. Edu Lobo e Carlos Lyra: o nacional e o popular na canção de protesto (os anos 60). Revista brasileira de História, v. 18, n. 35, p. 13-52, 1998.

DANIELSEN, Anne. Aesthetic value, cultural significance, and canon formation in popular music. In: BIELEFELDT, Christian; DAHMEN, Udo; GROßMANN, Rolf (Ed.). PopMusicology: Perspektiven der Popmusikwissenschaft. transcript Verlag, 2015. 
DENORA, Tia. Music and Social Experience. In: JACOBS, Mark; HANRAHAN, Nancy. The Blackwell Companion to Sociology Of Culture. Blackwell Publishing, 1995.

DENORA, Tia. After Adorno: Rethinking Music Sociology. Cambridge: Cambridge University Press, 2003.

DENORA, Tia. Music in Everyday Life. Cambridge: Cambridge University Press, 2004.

DIAS, Márcia Tosta. Os Donos da Voz. São Paulo: Boitempo, 2000.

ELIAS, Norbert. Mozart: sociologia de um gênio. Rio de Janeiro: Jorge Zahar, 1995.

ESQUENAZI. Jean-Pierre. Sociologie des oeuvres. De la production à l'interprétation. Paris: Armand Colin, 2007.

FAVARETTO, Celso. Tropicália: alegoria, alegria. $2^{\mathrm{a}}$ ed. São Paulo: Ateliê Editorial, 1996.

FAUSTO, Boris. História concisa do Brasil. São Paulo: Edusp, 1994.

FENERICK, José Adriano. Outros fins e outros sons: a metrópole e a "Vanguarda Paulista". In: MNEME - Revista de humanidades, Publicação do Departamento de História e Geografia da Universidade Federal do Rio Grande do Norte - Centro de Ensino Superior do Seridó - Campus de Caicó, v.4 - n.8 - abr./set. de 2003. p. 241-260.

FENERICK, José Adriano. Façanhas às próprias custas: A produção musical da Vanguarda Paulista. (1979-2000). São Paulo: Annablume; Fapesp, 2007.

FLICK, Uwe; Ernst von Kardorff; Ines Steinke (Hrsg.). Qualitative Forschung. Ein Handbuch. 2003.

FOUCAULT. Michel. O que é um autor? Em : Ditos e Escritos: Estética - literatura e pintura, música e cinema (vol. III). Rio de Janeiro : Forense Universitária, 2001. p. 264298.

FRITH, Simon. Performing Rites: on the value of popular music. Cambridge: Harvard University Press, 1998.

GARCIA, Walter. Bim Bom: a contradição sem conflitos de João Gilberto. São Paulo: Paz e Terra, 1999.

GARCIA, Walter. "Clara Crocodilo" e "Nego Dito": dois perigosos marginais?. Antíteses, v. 8, n. 15, 2015.

GARCIA, Walter. Melancolias, Mercadorias: Dorival Caymmi, Chico Buarque, o pregão de rua e a canção popular-comercial no Brasil. Cotia: Ateliê Editorial, 2013.

GAÚNA, Regiane. Rogério Duprat: Sonoridades múltiplas. São Paulo: Ed. Unesp, 2001.

GHEZZI, Daniela Ribas. De um porão para o mundo: A vanguarda paulista e a 
produção independente de LP's através do selo Lira Paulistana nos anos 80 - um estudo dos campos fonográfico e musical. 2003. Dissertação de Mestrado - Universidade Estadual de Campinas. Instituto de Filosofia e Ciências Humanas. Departamento de Sociologia.

GOFFMAN, Erving. A Representação do Eu na Vida Cotidiana. 6a . ed. Petrópolis: Vozes, 1985.

GOFFMAN, Erving. Gender Advertisements. New York: Harper and Row Publishers, 1976.

GOFFMAN, Erving. Forms of Talk. University of Pennsylvania Press, 1981.

Greimas, A. J.; Courtès, J. Dicionário de semiótica. 2. ed. São Paulo: Contexto, 2011.

GULLAR, Ferreira. Cultura posta em questãoem questão. Arte em Revista v.2, n. 3., março 1980, p. 83-87.

HALL, Stuart. The Work of Representation. In: HALL, Stuart; EVANS, Jessica; NIXON, Sean, Representation. London: Sage Publication, 2013.

HALL, Stuart. Encoding/Decoding. In: HALL, Stuart; HOBSON, Doothy; LOWE, Andrew; WILlIS, Paul. Culture, Media, Language: Working Papers in Cultural Studies, 1972-79. London: Routledge, 2004

KATER, Carlos. Música Viva e H. J. Koellreuter: movimentos em direção à modernidade. São Paulo: Musa, 2001.

LEPPERT, Richard (org). Essays on Music: Theodor Adorno. Berkeley: University of California Press, 2002.

MACHADO, Regina. A voz na canção popular brasileira: um estudo sobre a Vanguarda Paulista. 2007. Dissertação de Mestrado - Universidade Estadual de Campinas. Instituto de Artes.

MAMMÌ, Lorenzo. João Gilberto e o projeto utópico da bossa nova. Novos Estudos, no 34. São Paulo, Cebrap, nov.1992. pp. 63-70.

MARTINS, Carlos Eduardo Estevam. História do CPC. Arte em Revista v.2, n. 3., março 1980, p.77-82.

MARTINS, Carlos Eduardo Estevam. A questão da cultura popular. Rio de Janeiro: Tempo Brasileiro, 1963.

MARRACH, Sonia Alem. Música e universidade na cidade de São Paulo: do samba de Vanzolini à Vanguarda Paulista. São Paulo: Editora Unesp, 2011.

MED, Bohumil . Teoria da música. Brasília: Musimed, 1996.

MEDAGLIA, Júlio. Música Impopular. São Paulo: Global, 1988. 
MELLO, Zuza Homem de. A era dos festivais: uma parábola. São Paulo: Editora 34, 2003.

MIDDLETON, Richard. Studying Popular Music. Buckingham: Open University Press, 1990.

MORAES, José Geraldo Vinci de. História e música: canção popular e conhecimento histórico. Revista brasileira de história, $\mathrm{n}^{\circ} 38$. Versão eletrônica. http://www.scielo.br/pdf/rbh/v20n39/2987.pdf.

MORAES, José Geraldo Vinci de. Metrópole em Sinfonia. História, Cultura e Música Popular em São Paulo nos anos 30. São Paulo, Ed. Estação Liberdade, 2000.

MURGEL, Ana Carolina Arruda de Toledo. Alice Ruiz, Alzira Espíndola, Tetê Espíndola e Ná Ozzetti: produção musical feminina na Vanguarda Paulista. 2005. Dissertação de Mestrado - Universidade Estadual de Campinas. Instituto de Filosofia e Ciências Humanas. Departamento de História.

NAPOLITANO, Marcos. A síncope das idéias: a questão da tradição na música popular brasileira. São Paulo: Ed. Fundação Perseu Abramo, 2007.

NAPOLITANO, Marcos. A música popular brasileira (MPB) dos anos 70: resistência política e consumo cultural. Disponível em http://www.hist.puc.cl/historia/iaspmla.html

NAPOLITANO, Marcos. Cultura brasileira: Utopia e massificação (1950/1980). 3a Ed. São Paulo: Contexto, 2006.

NAPOLITANO, Marcos. O conceito de « MPB » nos anos 60. História. Questões e Debates. Curitiba: Ed. da UFPR, vol. 1, n 30, jan/jun 1999.

NAPOLITANO, Marcos. Seguindo a canção: engajamento político e indústria cultural na MPB (1959-1969). São Paulo: Annablume/FAPESP, 2001.

NAPOLITANO, Marcos. História e Música. Belo Horizonte: Autêntica, 2002.

NAVES, Santuza Cambraia. Da Bossa Nova à Tropicália. Rio de Janeiro: Zahar, 2001.

NAVES, Santuza Cambraia. A canção brasileira: leituras do Brasil através da música. Rio de Janeiro: Zahar. 2015.

NAZARIO, Luiz . O universo de Clara Crocodilo . Revista do Instituto de Estudos Brasileiros, Brasil, n. 59, p. 413-418, dec. 2014. ISSN 2316-901X. Disponível em:

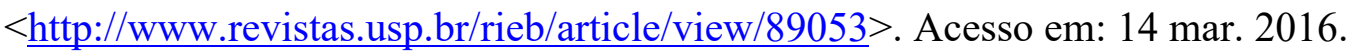

OLIVEIRA, Laerte Fernandes de. Em um porão de São Paulo: O Lira Paulistana e a produção alternativa. São Paulo: Editora Brasiliense: Annablume: Fapesp, 2002.

ORTIZ, Renato. A moderna tradição brasileira: cultura brasileira e indústria cultural. São Paulo: Brasiliense, 1988. 
ORTZ, Renato. Cultura brasileira e identidade nacional. São Paulo: Editora Brasiliense, 1985.

ORTIZ, Renato. Mundialização e Cultura. São Paulo: Brasiliense, 2000.

PERRONE, C. A., \& DUNN, C. (Org.): Brazilian popular music and globalization.

New York; London: Routledge, 2002.

POLETTO, Fabio Guilherme. Saudade do Brasil: Tom Jobim na cena musical brasileira (1963-1976). 2010. Tese de Doutorado. Universidade de São Paulo.

RIDENTI, Marcelo. Em busca do povo brasileiro: artistas da revolução, do CPC à era da TV. São Paulo: Editora Unesp, 2014.

SADER, Eder. Quando novos personagens entraram em cena. Rio de Janeiro: Paz e Terra, 1988.

SANDRONI, Carlos. Feitiço descente: transformações do samba no Rio de Janeiro, 1917-1933. São Paulo: Zahar, 2001.

SANT'ANNA, A. Romano. Música popular e moderna poesia brasileira. São Paulo: Nova Alexandria, 2013.

SCHWARZ, Roberto. O pai de família e outros estudos. $2^{\mathrm{a}}$ ed. Rio de Janeiro: Paz e Terra, 1978.

SCHWARZ, Roberto. Ao Vencedor as Batatas: Forma literária e processo social nos inícios do romance brasileiro. São Paulo: Duas Cidades / Ed. 34, 2000.

SCHWARZ, Roberto. Sequências brasileiras. São Paulo: Companhia das Letras, 1999.

SCHWARZ, Roberto. Que Horas São? São Paulo: Companhia das Letras, 1987.

SCHWARZ, Roberto. Cultura na Política, 1964-1969. Rio de Janeiro: Paz e Terra, 2001.

SCHWARZ, Roberto. Martinha versus Lucrécia. São Paulo: Companhia das Letras, 2012

SQUEFF, Enio. Vila Madalena: Crônica histórica e sentimental. São Paulo: Boitempo Editorial. 2002.

STARLING, Heloisa; SCHWARCZ, Lilia Moritz. Brasil: uma biografia. São Paulo: Companhia das Letras, 2015.

STROUD, Sean. Música popular brasileira experimental - Itamar Assumpção, a vanguarda paulista e a tropicália. REVISTA USP, São Paulo, n.87, 2010.

TARUSKIN, Richard. The Oxford History of Western Music. Oxford: Oxford University Press, 2005.

TATIT, Luiz. A Canção, Eficácia e Encanto. São Paulo: Atual Editora, 1986. 
TATIT, Luiz. Análise Semiótica Através das Letras. São Paulo: Ateliê Editorial, 2001.

TATIT, Luiz; LOPES, I. C.. Elos de Melodia e Letra. São Paulo: Ateliê Editorial, 2008.

TATIT, Luiz. Musicando a Semiótica: Ensaios. São Paulo: AnnaBlume, 1997.

TATIT, Luiz. O Cancionista: Composição de Canções no Brasil. São Paulo:

Edusp,1996.

TATIT, Luiz. O Século da Canção. São Paulo: Ateliê Editorial, 2004.

TATIT, Luiz. Semiótica da Canção: Melodia e Letra. São Paulo: Escuta, 1994.

TATIT. Luiz. Todos Entoam: Ensaios, Conversas e Lembranças. Cotia: Ateliê Editorial, 2014.

TATIT, Luiz. Estimar Canções: Estimativas Íntimas na Formação do Sentido. Cotia, SP: Ateliê Editorial, 2016.

TATIT, L. ; NESTROVSKI, A. ; MAMMÌ, L. . Três Canções de Tom Jobim. São Paulo: Cosac Naify, 2004.

TAUSSING, Michael. Mimesis and Alterity: a particulary history of the senses. New York: Routledge, 1993.

TINHORÃO, José Ramos. História social da música popular brasileira. São Paulo: Ed. 34, 1998.

VELOSO, Caetano. Verdade tropical. São Paulo: Companhia das Letras, 1997.

VIANNA. Hermano. O mistério do samba. Rio de Janeiro: Zahar, 1995.

WALTER, Benjamin. Magia e técnica, arte e política. São Paulo: Brasiliense, 2012.

WEBER, Max. Economia e Sociedade: Fundamentos da Sociologia Compreensiva. Brasília: Editora Universidade de Brasília, 1991. 2v.

WEBER, Max. Os fundamentos racionais e sociológicos da música. São Paulo: Edusp, 1995.

WILLIAMS, Raymond. A política e as letras. São Paulo: Editora Unesp, 2013.

WISNIK. Guilherme. Cerimônia mostrou um Brasil que ainda pulsa e se atualiza diante de nós. Folha de São Paulo. São Paulo, 08 agosto 2016. Disponível em:

http://www1.folha.uol.com.br/colunas/guilherme-wisnik/2016/08/1800104-cerimoniamostrou-um-brasil-que-ainda-pulsa-e-se-atualiza-diante-de-nos.shtml. Acesso em: $03 / 01 / 2017$

WISNIK, José Miguel. O coro dos contrários. São Paulo: Duas Cidades: SCCT, 1977 
WISNIK, José Miguel. O Som e o Sentido. São Paulo: Companhia das Letras, 1989.

WISNIK, José Miguel. Sem receita. São Paulo: Publifolha, 2004.

WISNIK, José Miguel., SQUEFF, E. O nacional e o popular na cultura brasileira: música. São Paulo: Brasiliense, 1982.

XAVIER, Ismail. Alegorias do subdesenvolvimento: Cinema Novo, Tropicalismo e Cinema Marginal. São Paulo: Cosac Naify, 1993.

\section{Discografia da vanguarda paulista :}

\section{Rumo:}

Rumo(1981), Rumo aos antigos (1982), Diletantismo (1983), Caprichoso (1986), Quero passear( 1988)

\section{Arrigo Barnabé:}

Clara Crocodilo (1980), Tubarões Voadores (1984), Cidade Oculta (1986), Suspeito( 1987), Façanhas (1992), Coletânea 25 anos de Clara Crocodilo (2004).

\section{Itamar Assumpção:}

Beleléu, Leléu, Eu (1980), Às Próprias Custas S/A(1981), Sampa Midnight - Isso não vai ficar assim (1983), Intercontinental! Quem diria! Era só o que faltava!!! (1988), Bicho de Sete Cabeças Vol I, II, III,(1993), Pretobrás (1998).

Premeditando o Breque: Premeditando o Breque/Empada Molotov Fervura [1980], Premeditando o Breque (1981), Quase Lindo (1983), O melhor dos iguais (1985), Grande Coisa (1986), Alegria dos homens (1991).

\section{Língua de Trapo:}

Língua de Trapo (1982), Como é Bom Ser Punk (1985), 17 Big Golden Hits Super Quentes Mais Vendidos No Momento (1986), Sutil como um Cassetete (1980), Sem Indiretas (1984) 